Jefferson Luiz Rangel Rios

Avaliação metrológica de um dispositivo servohidráulico para mitigação de incrustação em trocadores de calor industriais

Dissertação de Mestrado

Dissertação apresentada como requisito parcial para obtenção do grau de Mestre pelo Programa de PósGraduação em Metrologia (Área de concentração: Metrologia para Qualidade e Inovação) da PUC-Rio.

Orientador: Maurício Nogueira Frota Coorientador: José Daniel Hernández-Vásquez

Rio de Janeiro

Dezembro de 2020 
Jefferson Luiz Rangel Rios

\section{Avaliação metrológica de um dispositivo servo-hidráulico para mitigação de incrustação em trocadores de calor \\ industriais}

Dissertação de Mestrado Dissertação apresentada como requisito parcial para obtenção do grau de Mestre pelo Programa de PósGraduação em Metrologia (Área de concentração: Metrologia para Qualidade e Inovação) da PUC-Rio. Aprovada pela Comissão Examinadora abaixo assinada:

Prof. Maurício Nogueira Frota

Orientador

Programa de Pós-Graduação em Metrologia - PUC-Rio

Prof. José Daniel Hernández-Vásquez

Coorientador

Programa de Engenharia Mecânica/FIMEB - UAN/Colômbia

Prof. Carlos Roberto Hall Barbosa

Programa de Pós-Graduação em Metrologia - PUC-Rio

Prof. José Alberto dos Reis Parise

Departamento de Engenharia Mecânica - PUC-Rio

Dra. Khrissy Aracélly Reis Medeiros

Departamento de Engenharia Mecânica - PUC-Rio

Rio de Janeiro, 21 de dezembro de 2020. 
Todos os direitos reservados. É proibida a reprodução total ou parcial do trabalho sem autorização da universidade, do autor e do orientador.

\section{Jefferson Luiz Rangel Rios}

Formado em Engenharia Mecânica (2017) pela Pontifícia Universidade Católica do Rio de Janeiro. Consultor para assuntos de engenharia mecânica no Programa de Pósgraduação em Metrologia - PUC-Rio. Pesquisador do Projeto de P\&D Light-Aneel Ref.: 5161-010/2016, Cabeça de Série de um sistema inovador de limpeza de trocadores de calor de hidrogeradores.

Ficha Catalográfica

Rios, Jefferson Luiz Rangel

Avaliação metrológica de um dispositivo servo-hidráulico para mitigação de incrustação em trocadores de calor industriais / Jefferson Luiz Rangel Rios ; orientador: Maurício Nogueira Frota ; coorientador: José Daniel Hernández-Vásquez. - 2020.

155 f. : il. color. ; $30 \mathrm{~cm}$

Dissertação (mestrado)-Pontifícia Universidade Católica do Rio de Janeiro, Centro Técnico Científico, Programa de Pós-Graduação em Metrologia, 2020.

Inclui bibliografia

1. Metrologia - Teses. 2. Metrologia para Qualidade e Inovação - Teses. 3. Metrologia. 4. Trocadores de calor. 5. Mitigação de incrustações. 6. Sistema de limpeza por esfera abrasiva. 7. Calibração de instrumentos. I. Frota, Maurício Nogueira. II. Hernández-Vásquez, José Daniel. III. Pontifícia Universidade Católica do Rio de Janeiro. Centro Técnico Científico. Programa de Pós-Graduação em Metrologia. IV. Título. 
"Porque Deus amou ao mundo de tal maneira que deu o seu Filho unigênito, para que todo o que nele crê não pereça, mas tenha a vida eterna."

João 3:16 


\section{Agradecimentos}

Primeiramente agradeço a Deus, que permitiu que tudo acontecesse, ao longo de minha vida. Ele é o autor e consumador da vida.

À minha família, em especial Maria das Graças da Silva Rodrigues, Maria Aparecida Gabriel Lima (in memoriam) e Maria de Lourdes da Silva (in memoriam), irmãos da Igreja e amigos de longa data, como Thieplo Bertola, pelo constante apoio e por tornarem possível mais esse sonho.

Ao orientador, Professor Maurício Nogueira Frota, por ter acreditado e investido naquele jovem que o enviou um e-mail há 6 anos. Pela oportunidade de trabalhar de forma independente, mas sempre bem supervisionada e orientada para que buscasse a excelência. Pela sua confiança demonstrada, o carinho paternal, apoio, incrível capacidade de liderança motivadora, sabendo encorajar-nos em todos os momentos e fazendo acreditar que sempre somos capazes.

Ao Dr. José Daniel Hernández Vásquez, atualmente professor e pesquisador do Programa de Ingeniería Mecánica da Universidad Antonio Nariño, Barranquilla - Colombia, pela dedicada coorientação e presteza desde a graduação, sempre oferecendo uma solução inteligente e colaborando com seu empenho característico e marcante.

À equipe de profissionais da Maroni Indústria Mecânica, em especial Seu Vanderlei, Seu Jurandir e Antônio (Catureba) que trabalharam diretamente na montagem e manutenção do equipamento. Ao senhor Mário, sempre contribuindo com excelentes ideias e compartilhando experiências. À empresa CETEM Automação Industrial Ltda., pela colaboração na automação do sistema. À Light e à PUC-Rio, pela oportunidade de colaborar com o desenvolvimento do Projeto de P\&D Light-Aneel Ref.: 5161-010/2016, Cabeça de Série de um sistema inovador de limpeza de trocadores de calor de hidrogeradores. A todos do Laboratório de Ensaios Mecânicos da PUC-Rio, por disponibilizarem acesso e apoio durante a realização dos diversos ensaios.

Ao professor José Alberto dos Reis Parise, pelo constante apoio e motivação ao longo de minha formação acadêmica de graduação e pós-graduação.

À equipe de pesquisadores da PUC-Rio, em especial ao Sérgio Bragantine, sempre proativo e disponível para solução de problemas e ao Velfe Oliveira, que se tornou amigo próximo e muito colaborou no desenvolvimento da pesquisa bibliográfica.

Aos amigos André Pimentel, Edson Sabino, Felipe Lanes, Gabriel Motta, João Henrique, Cristiano Sandroni, Eduardo Machado, João Pinheiro, Luciano Belezia, Vicente Lorenzon, Márcia Borges, Ângela Filomena Perricone, Débora Mondaini, Carlos Alberto de Almeida, Waldemar Monteiro, Pedro Paulo Silva, Roberta Dutra e Daniel Louzada, amigos que fiz na PUC, mas que seguirão ao longo de nossas vidas.

A todos professores e corpo administrativo do Programa de Pós-graduação em Metrologia, em especial à Márcia Ribeiro e Paula Molinari, pelo desprendido apoio compartilhado, sempre com entusiasmo e afetividade durante minha vida acadêmica no programa POSMQI. Sempre ofereceram soluções pelas rápidas e eficientes para superar problemas burocráticos, e sempre amáveis nos divertidos almoços compartilhados.

Aos professores da Banca Examinadora, por terem aceitado avaliar o trabalho.

Ao Conselho Nacional de Desenvolvimento Cientifico e Tecnológico (CNPq), pela bolsa de estudos durante o curso de mestrado.

O presente trabalho foi realizado com apoio da Coordenação de Aperfeiçoamento de Pessoal de Nível Superior - Brasil (CAPES) - Código de Financiamento 001. 


\title{
Resumo
}

\begin{abstract}
Rios, Jefferson Luiz Rangel. Frota, Maurício Nogueira (Orientador). Hernández-Vásquez, José Daniel (Coorientador). Avaliação metrológica de um dispositivo servo-hidráulico para mitigação de incrustação em trocadores de calor industriais. Rio de Janeiro, 2020. 155p. Dissertação de Mestrado - Programa de Pós-Graduação em Metrologia (Área de concentração: Metrologia para Qualidade e Inovação), Pontifícia Universidade Católica do Rio de Janeiro.
\end{abstract}

Incrustações em trocadores de calor são inevitáveis e provocam a redução da sua efetividade térmica e aumento nos custos de bombeamento. Esta dissertação objetiva validar um dispositivo alternativo de limpeza de trocadores de calor, que automatiza o processo e não requer a interrupção do processo industrial que faz uso de trocadores. A motivação da pesquisa resultou do desafio imposto ao Programa de Metrologia da PUC-Rio para conceber uma solução inovadora para realizar a limpeza on-line de trocadores de calor de hidrogeradores, viabilizada com financiamento do setor elétrico e que motivou esta dissertação. A metodologia de desenvolvimento da pesquisa de mestrado perseguiu duas estratégias de otimização: (i) aprimorar a hidrodinâmica dos circuitos hidráulicos do dispositivo de limpeza concebido, visando reduzir custos de bombeamento e (ii) simular o número de ciclos mínimos de limpeza para assegurar que todos os tubos do trocador de calor sejam visitados por artefatos de limpeza. Dentre os resultados consolidados, destacam-se: (i) melhoria dos fluxos hidrodinâmicos nos distintos tramos hidráulicos do dispositivo servohidráulico de limpeza; (ii) confiabilidade metrológica do sistema de medição embarcada no equipamento e (iii) desenvolvimento de modelagem probabilística capaz de prever o número de ciclos de limpeza capaz de assegurar eficácia do procedimento de limpeza do trocador, o que contribui para o seu entendimento. Os ensaios de desempenho realizados em laboratório suportam a conclusão de que a pesquisa de mestrado foi capaz de validar e disponibilizar uma versão hidrodinamicamente mais eficiente e operacionalmente mais eficaz do dispositivo de limpeza originalmente concebido.

\section{Palavras-chave}

Metrologia; trocadores de calor; mitigação de incrustações; esfera abrasiva; limpeza por esferas abrasivas; calibração de instrumentos. 


\section{Abstract}

Rios, Jefferson Luiz Rangel. Frota, Mauricio Nogueira (Advisor). HernándezVásquez, José Daniel (Co-advisor). Metrological evaluation of a servohydraulic device to mitigate fouling in industrial heat exchangers. Rio de Janeiro, 2020. 155p. Dissertação de Mestrado - Programa de PósGraduação em Metrologia (Área de concentração: Metrologia para Qualidade e Inovação), Pontifícia Universidade Católica do Rio de Janeiro.

Fouling in heat exchangers is inevitable and causes a reduction in their thermal effectiveness and an increase in pumping costs. This dissertation aims to validate an alternative heat exchanger cleaning device, which automates the process and does not require the interruption of the industrial process that uses exchangers. The motivation for the research resulted from the challenge imposed on the Metrology Program at PUC-Rio to devise an innovative solution to perform the online cleaning of hydrogenerator heat exchangers, made possible with financing from the electricity sector and which motivated this dissertation. The master's research development methodology pursued two optimization strategies: (i) improving the hydrodynamics of the hydraulic circuits of the designed cleaning device, aiming to reduce pumping costs and (ii) simulating the number of minimum cleaning cycles to ensure that all the tubes of the heat exchanger are visited by cleaning artefacts. Among the consolidated results, the following stand out: (i) improvement of hydrodynamic flows in the different hydraulic sections of the servohydraulic cleaning device; (ii) metrological reliability of the measurement system embarked in the equipment and (iii) development of probabilistic modeling capable of predicting the number of cleaning cycles capable of ensuring the efficiency of the exchanger cleaning procedure, which contributes to its understanding. The performance tests performed in the laboratory support the conclusion that the master's research was able to validate and make available a hydrodynamically more efficient and operationally more effective version of the cleaning device originally designed.

\section{Keywords}

Metrology; heat exchangers; fouling mitigation; abrasive spheres; abrasive spheres cleaning process; instrument calibration. 


\section{Sumário}

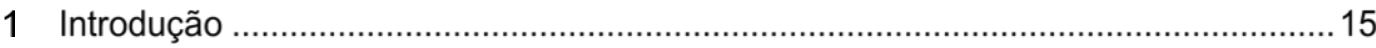

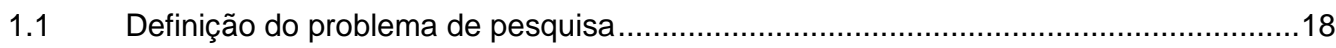

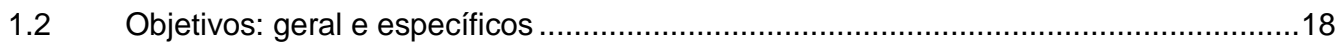

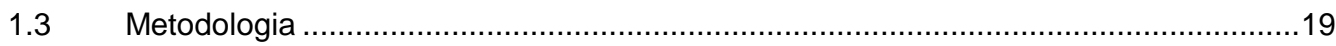

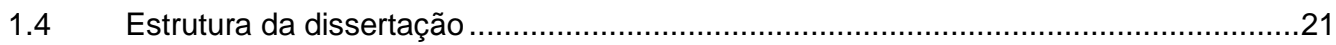

2 Estudo de artefatos e dispositivos de limpeza de trocadores....................................23

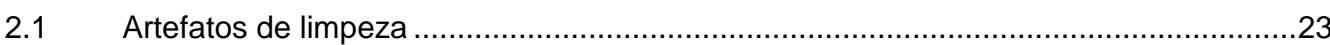

2.1.1 Critério para definição do diâmetro da esfera utilizada na limpeza ..........................24

2.1.2 Influência da velocidade da esfera no processo de limpeza ....................................26

2.1.3 Influência da rigidez da esfera abrasiva .................................................................27

2.1.4 Força de atrito atuante na esfera ao se movimentar no tubo do TC ........................30

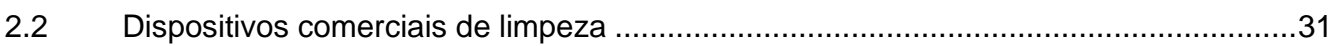

2.2.1 Sistema Taprogge de limpeza de trocador de calor ...........................................32

2.2.2 Sistema ATCS de limpeza de trocador de calor......................................................36

2.3 Dispositivos de limpeza proposto pelo PósMQI/PUC-Rio ...........................................39

2.3.1 Sistema manual de injeção e recuperação de esferas abrasivas ...........................40

2.3.2 Sistema automatizado de injeção e recuperação de esferas ...................................45

2.3.3 Versão compacta do sistema inovador de limpeza (SIREA 3) ................................50

2.3.3.1 Identificação e funcionamento da alternativa proposta ........................................51

2.3.3.2 Características do sistema alternativo de limpeza .........................................5

3 Validação do dispositivo de limpeza e estudo de seus ciclos ...................................55

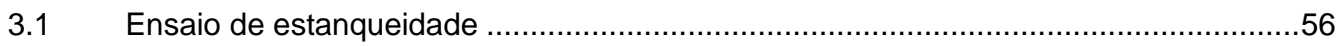

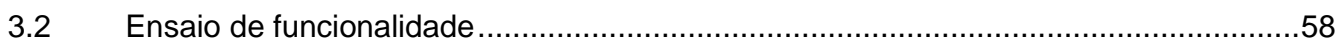

3.3 Qualificação metrológica do dispositivo de limpeza..................................................60

3.3.1 Visualização da eficácia de operação …………..................................................60

3.3.2 Avaliação de alternativas de pressurização do sistema.........................................61

3.3.2.1 Ensaio da bomba hidráulica (modelo 415 TJM 4 cv) ...........................................63

3.3.2.2 Ensaio da bomba hidráulica (modelo 615 TJM $5 \mathrm{cV}$ ).........................................63

3.3.2.3 Ensaio da bomba hidráulica (KSB, modelo 065-040-200, 20 cv) .......................64

3.4 Considerações sobre os ensaios de estanqueidade e funcionalidade ..........................64

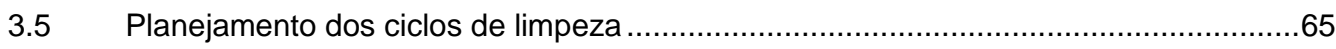

3.5.1 Definição do total de esferas............................................................................65

3.5.2 Determinação do número mínimo de ciclos de limpeza.............................................68

3.5.2.1 Análise da eficácia do ciclo de limpeza ………………………………….....70

3.5.2.2 Probabilidade de todos os tubos serem visitados uma única vez .......................73

3.5.2.3 Total adequado de ciclos de limpeza …………………………………....75

4 Sistema de medição embarcado no dispositivo de limpeza ......................................76

4.1 Confiabilidade metrológica do sistema de medição ......................................................76

4.1.1 Componente associado à resolução do instrumento …………………………...76

4.1.2 Componente associado ao padrão utilizado ……………………………...............77

4.1.3 Componente associado à repetibilidade da medição............................................77

4.1.4 Componente da incerteza associada ao ajuste pelo polinômio ………....................78

4.1.5 Critério de Chauvenet para exclusão de outliers ………………........................ 80

4.2 Funções operacionais e subsistemas de medição do SIREA 3 .................................. 81

4.2.1 Calibração do subsistema contador de esfera (CONDE) .....................................83

4.2.1.1 Caracterização do procedimento de calibração .......................................................84

4.2.1.2 Resultados da calibração dos parâmetros efetivos ...........................................90

4.2.2 Calibração do subsistema de medição de vazão .....................................................93

4.2.2.1 Caracterização dos medidores de vazão ……………………………….....94

4.2.2.2 Procedimento automatizado para calibração de medidores de vazão ..................95

4.2.2.3 Resultados da calibração dos medidores de vazão .........................................97

4.2.2.4 Comparação entre os métodos de calibração de vazão .....................................98

4.2.3 Calibração do subsistema de medição de pressão ............................................100

4.2.3.1 Caracterização do subsistema de medição de pressão ……………………...100

4.2.3.2 Resultados da calibração do subsistema de medição de pressão ......................102

4.2.4 Calibração do subsistema de medição de temperatura ..........................................104

4.2.4.1 Caracterização do subsistema de medição de temperatura ................................104

4.2.4.2 Resultados da calibração das termorresistências Pt 100 ...............................105

4.3 Automação do sistema de medição ....................................................................107 
4.4 Considerações sobre o capítulo ......................................................................107

5 Incorporação de melhorias no dispositivo de limpeza ......................................... 108

5.1 Versão 1.0 do SIREA 3 ........................................................................... 108

5.1.1 Medição de perdas de carga localizadas em tramos pré-selecionados .................110

5.1.2 Modificações no circuito hidráulico (alteração no projeto construtivo) ...................111

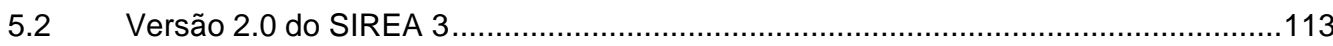

5.2.1 Melhorias introduzidas no sistema de limpeza ...................................................113

5.2.2 Avaliação das melhorias introduzidas .........................................................113

6 Conclusões e recomendações ...................................................................... 115

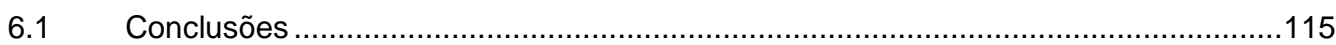

6.2 Recomendações para desdobramentos futuros ...............................................117

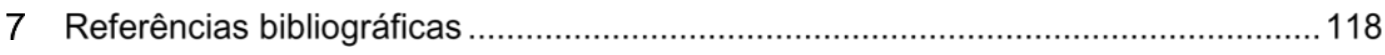

Apêndice A: Estudo para determinação do número de ciclos de limpeza..................... 122

Apêndice B: Calibração do contador de esferas ...................................................... 129

Apêndice C: Calibração do subsistema de vazão do dispositivo SIREA 3...................131

Apêndice D: Calibração do subsistema de medição de pressão...................................147

Apêndice E: Calibração do subsistema de temperatura .............................................. 150

Anexo A: Certificado de calibração do medidor de vazão Endress Hauser ...................152

Anexo B: Certificado de calibração do Manômetro Digital SALVI CASAGRANDE ........ 153

Anexo C: Certificado de calibração do banho térmico HAAKE ......................................154 


\section{Lista de Figuras}

Figura 1 - Trocador do tipo feixes tubulares..................................................................................15

Figura 2 - Funcionamento do trocador de calor tubo carcaça ...................................................16

Figura 3 - Chicanas de TC abertos para limpeza .........................................................................17

Figura 4 - Desenho da pesquisa, seus componentes e métodos......................................................20

Figura 5 - Mapa conceitual da pesquisa .............................................................................21

Figura 6 - Método (a) e eficácia (b) da limpeza por esfera abrasiva .........................................23

Figura 7 - Esfera típica utilizada para limpeza dos tubos do TC ...............................................24

Figura 8 - Tempo de encharcamento da esfera...........................................................................25

Figura 9 - Efeito do diâmetro da esfera na pressão do fluido .....................................................26

Figura 10 - Esfera abrasiva submetida ao ensaio de compressão ..................................................28

Figura 11 - Gráfico do módulo de elasticidade da esfera seca .....................................................29

Figura 12 - Gráfico do módulo de elasticidade da esfera encharcada .........................................29

Figura 13 - Gráfico de comparação da rigidez das esferas seca e encharcada .............................30

Figura 14 - Arranjo experimental (a) utilizado para medição da força de atrito máximo (b) ..........31

Figura 15 - Instalação típica do sistema Taprogge .....................................................................33

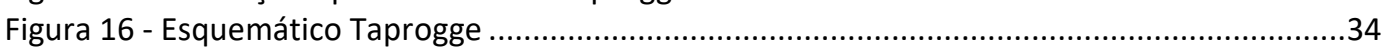

Figura 17 - Instalação típica de um sistema ATCS ...........................................................................37

Figura 18 - Esquema ATCS (fluxos de processo de injeção $(A)$ e recuperação de esfera (B))..........37

Figura 19 - Limpeza mecânica por varetagem .......................................................................40

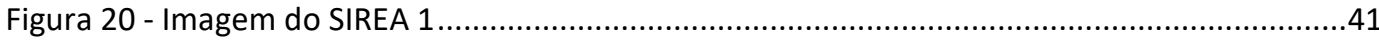

Figura 21 - Processo de injeção $(A)$ e recuperação $(B)$............................................................41

Figura 22. Projeto construtivo do Protótipo da versão automatizada do SIREA ............................46

Figura 23 - SIREA 2 acoplado ao sistema de arrefecimento do hidrogerador .................................46

Figura 24 - Processo de injeção (a) e recuperação (b) de esfera..................................................47

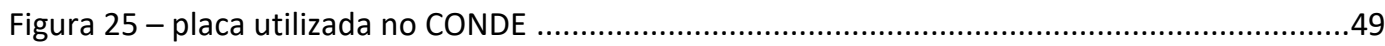

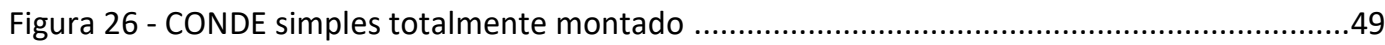

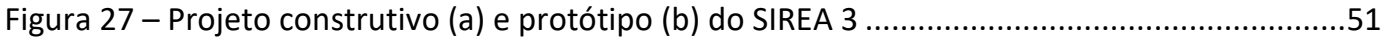

Figura 28 - Fluxo associado ao processo de injeção (a) e recuperação (b) de esfera .....................51

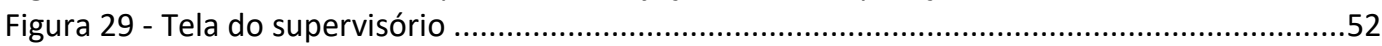

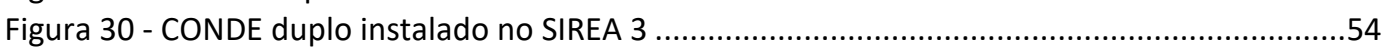

Figura 31 - Tela do supervisório do sistema de automação ......................................................55

Figura 32 - Acoplamento do sistema de limpeza ao reservatório de água ...................................56

Figura 33 - Instalação para monitoramento da pressão de recalque .........................................57

Figura 34 - Câmara de injeção alimentada com esferas abrasivas .............................................58

Figura 35 - Trocador de calor de acrílico utilizado para visualizar os ciclos de limpeza .................61

Figura 36 - Curvas de desempenho de bombas hidráulicas MJM/TJM ........................................62

Figura 37 - Curva de Calibração da bomba modelo 415 TJM, 4 cv ..............................................63

Figura 38 - Curvas de desempenho da família de bombas Dancor MJM/TJM .............................64

Figura 39 - Trocador de calor e compressor de um sistema típico de injeção de plástico .............66

Figura 40 - Chicana (a) e tubos (b) do trocador de calor do sistema de injeção de plástico ...........66

Figura 41 - Chicana superior (a) e inferior (b) do trocador de calor da usina Fontes Nova ............66

Figura 42 - Regiões de passe $(A)$ e sentido do fluxo $(B)$ no trocador de calor ...............................67

Figura 43 - Relação de ciclos para condição de êxito por penalidade aplicada..............................74

Figura 44 - Penalidade $x$ ciclos de limpeza ...............................................................................75

Figura 45 - Diâmetros efetivos e distância efetiva determinados pela passagem da esfera..........85

Figura 46 - Supervisório (a) montagem experimental (b) para determinação de $D_{\text {ef }}$ e Lef .............86

Figura 47 - CONDE duplo e esfera abrasiva utilizada no ensaio .............................................87

Figura 48 - Aparato experimental utilizado (osciloscópio, fonte de tensão e CONDE) ..................87

Figura 49 - Montagem concebida para forçar a esfera a interromper o feixe óptico ......................88

Figura 50 - Limiar de ativação dos sensores optoeletrônicos ....................................................89

Figura 51 - Identificação do zero "optoeletrônico" .........................................................................90

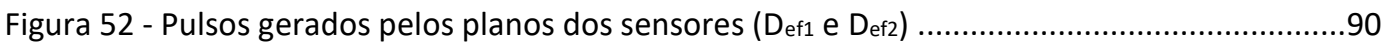

Figura 53 - Pulsos gerados pelos planos das placas (Lef) ......................................................92

Figura 54 - Medidor de vazão magnético Endress Hauser ........................................................94

Figura 55 - Medidor de vazão magnético $(A)$ e ultrassônico (B) ..............................................95 
Figura 56 - Critérios para posicionamento do medidor de vazão (a) e aparato experimental (b) ..96 Figura 57 - Sistema de aquisição de dados ...............................................................................96

Figura 58 - Medição de vazão com e sem o uso do FieldLogger (Inclui Erro) ...............................100

Figura 59 - Manômetro digital Salvi Casagrande (padrão) ......................................................101

Figura 60 - Instrumentos calibrados do subsistema de pressão ..............................................101

Figura 61 - Aparato experimental montado para a calibração dos instrumentos de pressão .......102

Figura 62 - Curvas de carga e descarga em ciclo histerético .................................................103

Figura 63 - Aparato experimental de calibração das termorresistências Pt 100..........................105

Figura 64 - Resultados das calibrações dos sensores de temperatura ......................................106

Figura 65 - Esquemático de pontos alterados do sistema ........................................................109

Figura 66 - Esquemático do circuito hidráulico ........................................................................110

Figura 67 - Alterações realizadas em componentes do sistema de limpeza ................................112

Figura 68 - Resultado das alterações realizadas no sistema de limpeza ....................................113

\section{Lista de Tabelas}

Tabela 1 - Configuração de válvulas, P2 e vazão durante injeção ..................................................59

Tabela 2 - Configuração de válvulas, P2 e vazão durante recuperação .........................................59

Tabela 3 - Configuração de válvulas, P2 e vazão durante o ensaio de lavagem de esfera ..............60

Tabela 4 - Parâmetros de entrada da distribuição Binomial Negativa .............................................70

Tabela 5 - Parâmetros associados à distribuição Binomial Negativa ...............................................71

Tabela 6 - Estudo de ciclos de limpeza ..................................................................................73

Tabela 7 - Procedimento de calibração para determinação de $D_{\text {ef1 }}$ e $D_{\text {ef2 }}$....................................91

Tabela 8 - Resultados de Diâmetros Efetivos e Espaçamento Efetivo ............................................93

Tabela 9 - Valores de média e desvio padrão da calibração de vazão .............................................98

Tabela 10 - Valores de incerteza expandidas dos medidores de vazão ..........................................98

Tabela 11 - Erro das médias do medidor IFM com o uso do FieldLogger e método tradicional .....99

Tabela 12 - Erro percentual em relação à média do medidor padrão ........................................99

Tabela 13 - Características metrológicas dos medidores calibrados..........................................104

Tabela 14 - Perda de carga imposta pelos tramos hidráulicos ..................................................111

Tabela 15 - Perdas de cargas impostas pelos tramos hidráulicos após alterações ........................114

Tabela 16 - Número de ciclos sem aplicação de penalidade ........................................................123

Tabela 17 - Número de ciclos com aplicação de penalidade de 10 \% ............................................123

Tabela 18 - Número de ciclos com aplicação de penalidade de 20 \% ..............................................124

Tabela 19 - Número de ciclos com aplicação de penalidade de 30 \% ...........................................124

Tabela 20 - Número de ciclos com aplicação de penalidade de 40 \% .........................................124

Tabela 21 - Número de ciclos com aplicação de penalidade de 50 \% ...........................................125

Tabela 22 - Número de ciclos com aplicação de penalidade de 60 \% ............................................126

Tabela 23 - Número de ciclos com aplicação de penalidade de 70 \% ..............................................126

Tabela 24 - Número de ciclos com aplicação de penalidade de 80 \% ...........................................127

Tabela 25 - Valores obtidos na medição de Def1 pelo procedimento de calibração ......................129

Tabela 26 - Valores obtidos na medição de Def2 pelo procedimento de calibração .....................129

Tabela 27 - Valores obtidos de LEF pelo procedimento de calibração .......................................130

Tabela 28 - Dados obtidos com o rotor da bomba hidráulica girando na frequência de $60 \mathrm{~Hz}$....132

Tabela 29 - Dados obtidos com o rotor da bomba hidráulica girando na frequência de $55 \mathrm{~Hz} \ldots . .133$

Tabela 30 - Dados obtidos com o rotor da bomba hidráulica girando na frequência de $50 \mathrm{~Hz}$....134

Tabela 31 - Dados obtidos com o rotor da bomba hidráulica girando na frequência de $45 \mathrm{~Hz}$....143

Tabela 32 - Dados obtidos com o rotor da bomba hidráulica girando na frequência de $40 \mathrm{~Hz}$....144

Tabela 33 - Dados obtidos com o rotor da bomba hidráulica girando na frequência de $35 \mathrm{~Hz} \ldots . .145$

Tabela 34 - Dados obtidos com o rotor da bomba hidráulica girando na frequência de $30 \mathrm{~Hz}$....146

Tabela 35 - Valores de medição de pressão do medidor P1 e manômetro padrão .......................147

Tabela 36 - Valores de medição de pressão do medidor P2 e manômetro padrão .......................147

Tabela 37 - Valores de medição de pressão do medidor P3 e manômetro padrão ......................147

Tabela 38 - Valores de medição de pressão do medidor diferencial e manômetro padrão .........148

Tabela 39 - Incertezas associadas ao transdutor de pressão P1 ..............................................148 
Tabela 40 - Incertezas associados ao transdutor de pressão P2 …..........................................148

Tabela 41 - Incertezas associados ao transdutor de pressão P3 .................................................148

Tabela 42 - Incertezas associados ao medidor de pressão diferencial........................................149

Tabela 43 - Incertezas associadas aos polinômios de ajuste .....................................................149

Tabela 44 - Erros sistemáticos associados aos valores corrigidos de $\mathrm{TS}_{1}$ e $\mathrm{TS}_{2}$...........................149

Tabela 45 - Valores de medição indicados pelas termorresistências e pelo padrão......................150

Tabela 46 - Coeficientes dos polinômios de ajuste gerados pela calibração de $\mathrm{TS}_{1}$ e $\mathrm{TS}_{2} \ldots . . . . . . . . . .150$

Tabela 47 - Valores indicados por $\mathrm{TS}_{1}$ e $\mathrm{TS}_{2}$, corrigidos pelos respectivos polinômios de ajuste .151

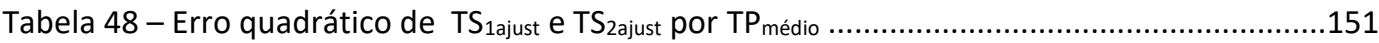

Tabela 49 - Respectivas incertezas associadas aos polinômios de ajuste ..................................151

Tabela 50 - Erros sistemáticos associados aos valores corrigidos de $\mathrm{TS}_{1}$ e $\mathrm{TS}_{2} \ldots \ldots \ldots \ldots \ldots \ldots \ldots \ldots \ldots . . . . . . . . . . . . . . .151$

\section{Lista de quadros}

Quadro 1 - Posição das válvulas para injeção de esfera do SIREA 1.............................................42

Quadro 2 - Posição de comando das válvulas para recuperação de esfera do SIREA 1 ..................43

Quadro 3 - Posição das válvulas para injeção de esfera do SIREA 2 ..........................................47

Quadro 4 - Posição das válvulas para recuperação de esfera do SIREA 2 ....................................48

Quadro 5 - Posição das válvulas para injeção de esferas ............................................................53

Quadro 6 - Posição das válvulas para recuperação de esferas...................................................53

\section{Lista de abreviaturas, siglas e símbolos}

\begin{tabular}{|c|c|}
\hline ATCS & Automatic Tube Cleaning System \\
\hline CLP & Circuito Lógico Programável \\
\hline CQM & Cooling Quality Management \\
\hline IHM & Interface Homem-Máquina \\
\hline SisMed & Sistema de medição \\
\hline SIREA & Sistema de injeção e recuperação de esferas abrasivas \\
\hline$A A$ & anel de alimentação de água de resfriamento \\
\hline Bomba & Bomba geradora do fluxo do SIREA 1 \\
\hline $\begin{array}{l}\text { Bomba } \\
\text { hidráulica }\end{array}$ & Bomba geradora do fluxo de água de resfriamento no sistema \\
\hline Ch & Chicana do trocador de calor \\
\hline $\mathrm{Cl}$ & Câmara de injeção de esfera \\
\hline CONDE & Contador de esferas/ duplo \\
\hline$C R$ & Câmara de recuperação de esfera \\
\hline Desc & Descarga de água de operação \\
\hline Dreno & $\begin{array}{l}\text { Dreno presente no sistema que auxilia no afogamento do } \\
\text { equipamento (enchimento com água) / } \\
\text { Drenos de ar instalados no sistema }\end{array}$ \\
\hline Inversor & Inversor de frequência utilizado no sistema \\
\hline$N A$ & Válvula solenoide normalmente aberta \\
\hline$N F$ & Válvula solenoide normalmente fechada \\
\hline Res & Reservatório de água de operação do sistema de limpeza \\
\hline Reservatório & Reservatório de água que alimenta a bomba hidráulica \\
\hline$R G$ & Registro manual para interrupção de fluxo \\
\hline$T C$ & Trocador de calor \\
\hline VNA & Válvula solenoide, do tipo Normalmente Aberta \\
\hline
\end{tabular}




\begin{tabular}{|c|c|}
\hline VNF & Válvula solenoide, do tipo Normalmente Fechada \\
\hline$V R$ & Válvula de retenção, para limitar o fluxo em um único sentido \\
\hline$P 1$ & Pressão na entrada da bomba hidráulica \\
\hline$P 2$ & Pressão no recalque da bomba hidráulica \\
\hline$P 3$ & Pressão na saída da Câmara de Injeção \\
\hline$T 1$ & Temperatura na entrada do trocador de calor \\
\hline T2 & Temperatura na saída do trocador de calor \\
\hline$V M_{i n j}$ & Válvula manual de injeção de esfera \\
\hline$V M_{t p r}$ & Válvula manual de transposição de esfera \\
\hline$V M_{\text {desc }}$ & $\begin{array}{l}\text { Válvula manual de descarga do fluido de transporte } \\
\text { da esfera }\end{array}$ \\
\hline$V S_{1}$ & $\begin{array}{l}\text { Válvula Solenoide de injeção / } \\
\text { Válvula solenoide, normalmente fechada }\end{array}$ \\
\hline$V S_{2}$ & $\begin{array}{l}\text { Válvula Solenoide de by pass / } \\
\text { Válvula solenoide, normalmente aberta }\end{array}$ \\
\hline$V S_{3}$ & Válvula motorizada de 3 vias \\
\hline$V S_{4}$ & $\begin{array}{l}\text { Válvula Solenoide de transposição / } \\
\text { Válvula solenoide, normalmente fechada }\end{array}$ \\
\hline$V S_{5}$ & $\begin{array}{l}\text { Válvula Solenoide de descarga / } \\
\text { Válvula solenoide, normalmente aberta }\end{array}$ \\
\hline$B_{f l u}$ & Bomba hidráulica geradora do fluxo principal do sistema \\
\hline$B_{\text {inj }}$ & Bomba centrífuga de rotor aberto de injeção de esfera \\
\hline$C_{i n j}$ & Câmara de injeção de esfera \\
\hline$C_{r e c}$ & Câmara de recuperação de esfera \\
\hline$P_{\text {dif }}$ & Pressão diferencial \\
\hline$S_{E s f}$ & Separador de esfera \\
\hline$T_{\text {Inj }}$ & Tramo de injeção de esfera \\
\hline$T_{\text {Rec }}$ & Tramo de recuperação de esfera \\
\hline$V_{l n j}$ & Válvula do fluxo de água de transporte (injeção) de esfera \\
\hline$B_{\operatorname{lnj}} / \operatorname{Rec}$ & $\begin{array}{l}\text { Bomba hidráulica auxiliar, de injeção e recuperação } \\
\text { de esfera }\end{array}$ \\
\hline $1_{\text {Inj }}$ & $\begin{array}{l}\text { Parte do fluxo principal é extraído por } B_{\operatorname{lnj}} / \operatorname{Rec} \text { / Bomba } \\
\text { impulsora do fluxo principal de água do SIREA } 1\end{array}$ \\
\hline $2 \ln j$ & $\begin{array}{l}\text { Fluxo gerado por BInj/Rec retira a esfera do coletor e a leva para } \\
\text { realizar a limpeza dos tubos do TC / } \\
\text { Fluxo parcial, desviado para a câmara de injeção }\end{array}$ \\
\hline $3 \ln j$ & $\begin{array}{l}\text { Esfera é inserida no TC / Junção dos fluxos de transporte } \\
\text { da esfera utilizada na limpeza dos tubos do TC }\end{array}$ \\
\hline $4 \ln j$ & Esfera deixa o TC / Esfera entra nos tubos internos do TC \\
\hline $5 \ln j$ & $\begin{array}{l}\text { Esfera é retirada do fluxo principal e fica retida no Separador / } \\
\text { Esfera sai dos tubos do TC }\end{array}$ \\
\hline $6_{\text {inj }}$ & Injeção da água do anel de alimentação \\
\hline $7_{i n j}$ & Esfera entra na câmara de recuperação \\
\hline $8_{i n j}$ & $\begin{array}{l}\text { Água oriunda da câmara de recuperação é utilizada } \\
\text { para alimentar a Bomba }\end{array}$ \\
\hline $1_{\text {rec }}$ & Bomba gera o fluxo principal de água \\
\hline $2_{\text {rec }}$ & Fluxo de água entra no TC \\
\hline $3_{\text {rec }}$ & Fluxo de água saí do TC \\
\hline
\end{tabular}




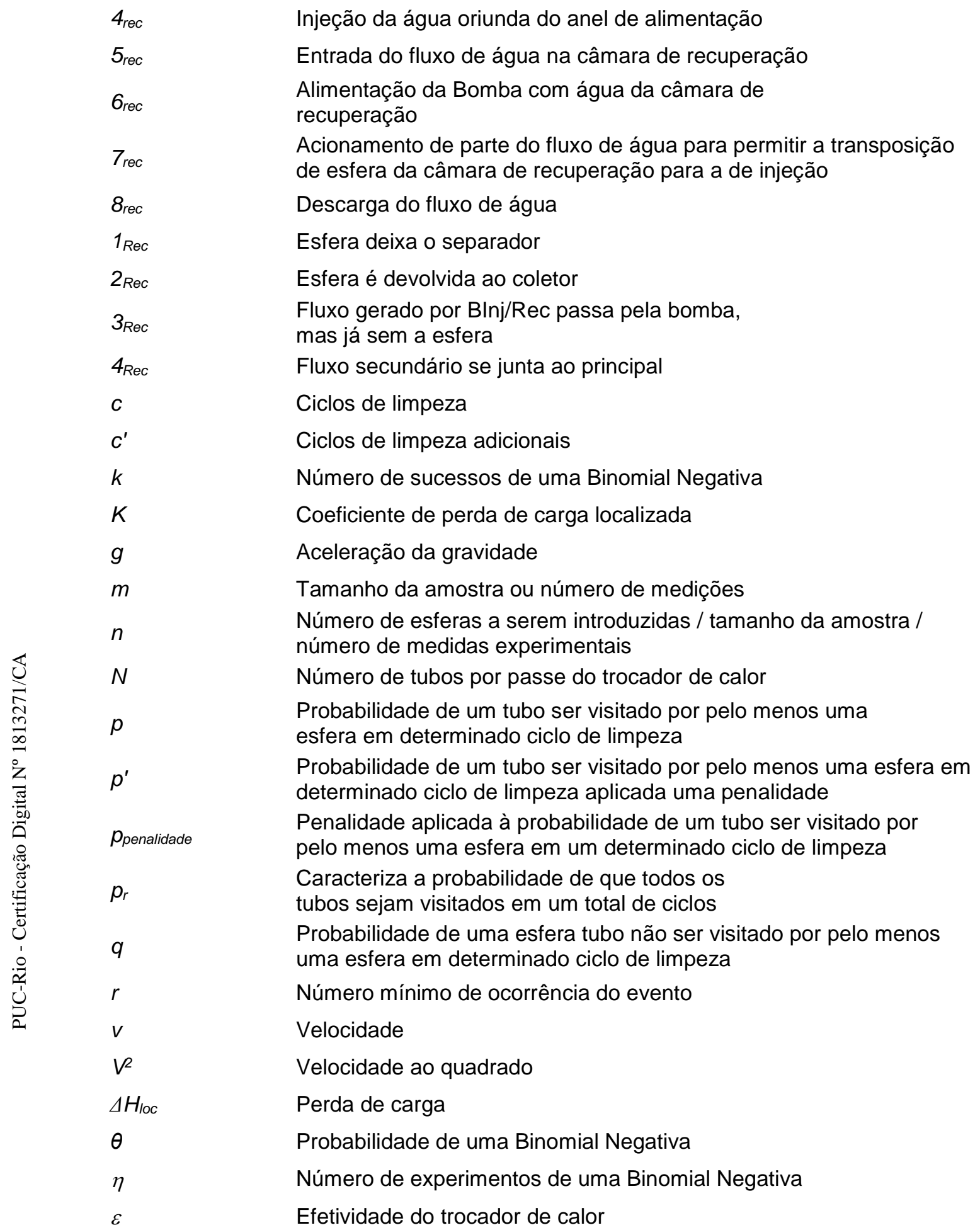




\section{1 \\ Introdução}

Trocadores de calor (TC) são equipamentos auxiliares e essenciais em diversos processos industriais (e.g.: geração de energia, metalurgia, indústrias de processos químicos). Via de regra utilizam-se dois fluidos de trabalho ("fluido quente" e "fluido frio"), que viabilizam a troca de calor entre partes do equipamento e o meio externo, assim assegurando níveis aceitáveis de temperatura desses processos. Trocadores de calor são, portanto, equipamentos que realizam a mudança do estado termodinâmico de seus fluidos de trabalho por meio da troca de energia térmica entre esses fluidos (Bergmann et al., 2016). Os fluidos de trabalho mais frequentes são água, ar, diversos tipos de óleo e fluidos refrigerantes, criteriosamente selecionados em função de suas propriedades termofísicas, químicas e termodinâmicas, tendo em vista a aplicação a que se destinam. Diversos são os tipos de trocadores disponíveis, selecionados em função da aplicação desejada. Dentre os mais utilizados, destacam-se os que utilizam feixes de tubulares, casco e tubo, placas paralelas, circular adiabático e o de placas aletadas. Não obstante esta diversidade de tipos de trocadores de calor, esta dissertação de Mestrado detém-se no estudo de trocadores que atendem aos requisitos técnicos compatíveis com a alternativa tecnológica de limpeza proposta. Mais especificamente, trocadores de calor com dutos circulares, assim permitindo a passagem de esferas abrasivas, utilizadas como artefatos de limpeza. A Figura 1 ilustra um desses trocadores utilizados no sistema de arrefecimento de hidrogeradores, que utiliza feixes de tubos paralelos para escoamento do fluido de trabalho frio, com escoamento cruzado, externo aos tubos, por onde escoa o fluido de trabalho quente. Usualmente, água (abundante na usina hidrelétrica) circula pelo interior dos tubos para resfriar o ar quente que circula, impulsionado por uma ventoinha acoplada ao eixo da turbina hidráulica.

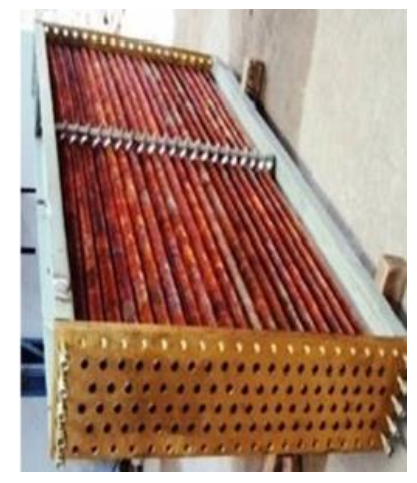

Figura 1 - Trocador do tipo feixes tubulares 
A Figura 2 mostra de forma esquemática o funcionamento de um TC do tipo casco e tubo, ilustrando os fluxos de ambos os fluidos de trabalho.

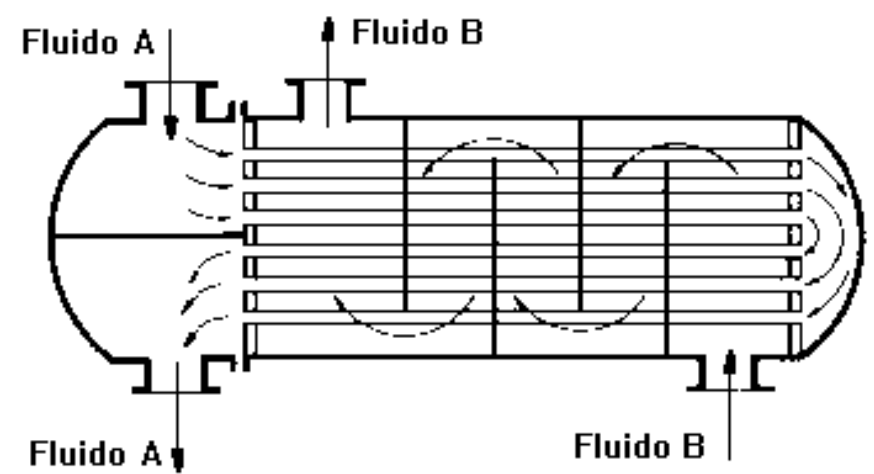

Figura 2 - Funcionamento do trocador de calor tubo carcaça Fonte: Rios, 2017

Dentre os indicadores utilizados para medir a qualidade de funcionamento do TC, a efetividade $(\varepsilon)$ - definida pela razão entre a quantidade real de calor trocada entre os fluidos de trabalho e o calor máximo que poderia ser trocado em condições termodinamicamente ideais - é comumente utilizada como parâmetro de monitoramento no meio industrial (Bergman et al., 2016). Esse indicador permite avaliar aspectos de interesse relacionados à economia de energia, desempenho operacional dos trocadores, bem como impactos de caráter econômico e ambiental. Por suas características térmicas favoráveis (elevado calor específico e propriedades termodinâmicas e mecânicas bem conhecidas), e não agressividade ao meio ambiente, a água é comumente utilizada como um dos fluidos de trabalho em trocadores. Entretanto, por originar-se de fontes minerais disponíveis e submetidas às intempéries do meio ambiente (e.g.: rios, mares), contém impurezas que se depositam na superfície interior dos tubos do TC. Desses depósitos resulta a formação de fouling que pode obstruir os tubos, drasticamente comprometendo a eficácia de operação do trocador. Fouling é a deposição de micro-organismos nas paredes internas do trocador de calor, também conhecido como incrustação, e necessita ser removida de tempos em tempos para evitar a obstrução parcial ou total dos tubos. Esta obstrução apresenta-se como perda de carga (perda de pressão) no interior do trocador, podendo colocar em risco a integridade da tubulação, reduzir a efetividade e requerer maior potência de bombeamento, o que impacta negativamente nos custos de operação.

A Figura 3 mostra alguns exemplos das condições adversas de operação dos trocadores de calor submetidos a fluidos de trabalho que deixam resíduos sólidos. As imagens mostram o interior de um trocador (após sua abertura para 
limpeza mecânica), que faz uso de chicanas para orientar o fluxo do fluido de trabalho circulante nos tubos. A figura mostra fotos do autor para evidenciar a incrustação nos compartimentos da chicana e nos tubos do trocador de calor.
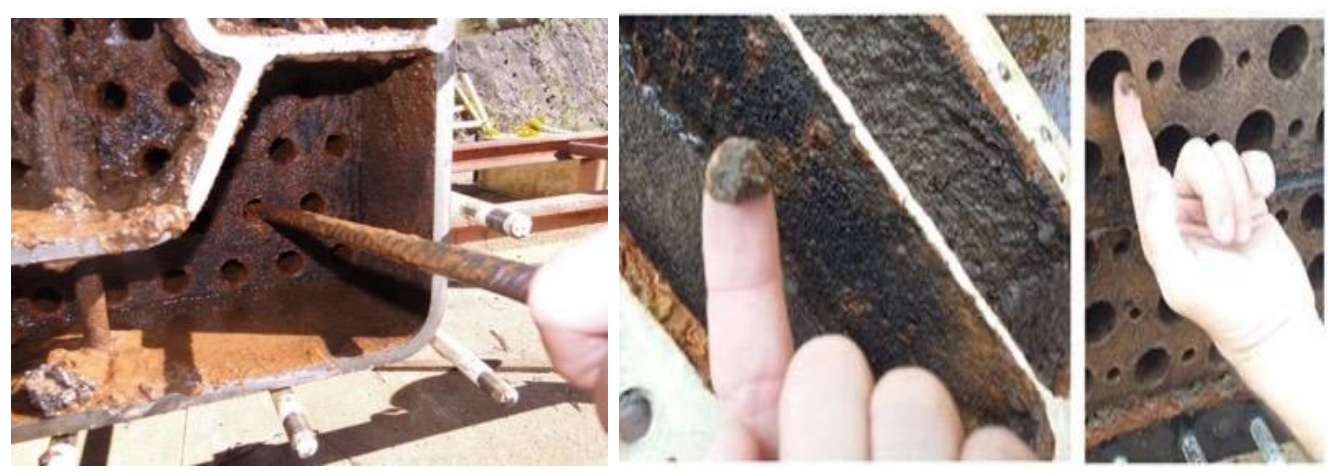

Figura 3 - Chicanas de TC abertos para limpeza

Conforme ilustrado acima, o procedimento de limpeza do TC faz-se necessário para assegurar eficácia do funcionamento do sistema de arrefecimento dos equipamentos de produção como um todo. Diversos são os métodos de limpeza descritos na literatura, selecionados em função do porte e da aplicação do TC; uns mais, outros menos eficientes na remoção da incrustação.

Alguns desses métodos utilizam produtos químicos (Oliveira, 2015), jateamento de água em alta pressão (Oliveira, 2015) e artefatos de limpeza, que são forçados pelas passagens internas do TC (Abd-Elhady \& Malayeri, 2015).

A necessidade de integrar métodos de limpeza a um sistema capaz de realizá-los de forma simples, rápida e, se possível, de forma autônoma, consta da pauta de prioridades dos agentes de manutenção da indústria, já que reduz o número de horas de trabalho de manutenção e permite antecipar a detecção de falhas. Em empresas cujos processos de produção são automatizados, a economia de matéria-prima e de tempo de manutenção é preocupação permanente de seus gestores de manutenção.

Entretanto, dentre as alternativas factíveis de serem implementadas, compete aos agentes de manutenção decidir e optar não apenas pelo método mais eficiente mas, principalmente, por aquele que mais bem se adequa às condições exigidas pelo local em que será instalado.

O objetivo desta dissertação é avaliar a confiabilidade metrológica de um sistema específico de limpeza, que faz uso de esferas abrasivas como artefatos de limpeza, para validar um equipamento concebido, desenvolvido e construído pelo Programa de Pós-Graduação em Metrologia no âmbito de um projeto de P\&D e também determinar um número ótimo de ciclos de limpeza necessários para garantir que todos os tubos do trocador de calor sejam visitados. Esse protótipo 
do sistema inovador é capaz de injetar e recuperar esferas em trocadores de calor de máquinas de diversos usos industriais, sem a necessidade de interromper o seu funcionamento.

Esta dissertação insere-se na linha de pesquisa "Instrumentação e medição" do Programa de Pós-graduação em Metrologia (PósMQI) da Pontifícia Universidade Católica do Rio de Janeiro (PUC-Rio).

\section{1}

\section{Definição do problema de pesquisa}

Considerando-se que:

- os sistemas de limpeza possuem diferentes arranjos, tamanhos, e aplicações distintas, faz-se necessário levar em conta esses fatores ao selecionar os sistemas de limpeza mais adequados ao seu propósito, em conformidade às condições de trabalho impostas;

- a medição e a avaliação dos parâmetros críticos do processo de limpeza se fazem necessárias para determinar (i) a eficácia do processo de limpeza; (ii) a eficiência do sistema de limpeza e (iii) a estimativa do número de ciclos de injeção de esferas para assegurar alta probabilidade de que todos os tubos sejam visitados pelos artefatos de limpeza;

- Há lacunas na literatura especializada sobre o tema central desta pesquisa, ou seja, avaliação de sistemas de limpeza de trocadores de calor, suas características de funcionamento e sua capacidade de limpeza,

consegue-se enunciar as seguintes questões norteadoras a serem respondidas ao longo da pesquisa:

(i) Como comprovar a eficácia de um sistema servo-hidráulico para mitigação de incrustação em trocadores de calor industriais?

(ii) Qual número de esferas e ciclos de limpeza necessários para garantir uma limpeza eficiente em todos os tubos?

(iii) Que medições críticas devem ser consideradas na avaliação do desempenho térmico e hidrodinâmico do sistema proposto?

(iv) Como aprimorar o desempenho do sistema de limpeza?

\section{2}

\section{Objetivos: geral e específicos}

Buscando-se responder às questões norteadoras acima enunciadas, definiu-se o objetivo geral da dissertação.

Objetivo: realizar a avaliação metrológica do sistema servo-hidráulico proposto para mitigação de incrustação em trocadores de calor industriais.

No que concerne aos objetivos específicos, a dissertação:

- Identifica, na literatura especializada, alternativas tecnicamente viáveis de mitigação de incrustação em trocadores de calor;

- Propõe um modelo estatístico para identificar o número ótimo de ciclos de limpeza para otimizar a operação do sistema proposto; 
- Estabelece os parâmetros metrológicos críticos para fundamentar a avaliação do dispositivo de limpeza proposto;

- Identifica os pontos críticos de perda de carga do sistema, visando a melhorias no projeto construtivo do dispositivo de limpeza;

- Implementa melhorias visando à otimização hidrodinâmica do sistema de limpeza.

\section{3 \\ Metodologia}

Em conformidade à taxonomia proposta por Vergara (2002), quanto aos fins a que se propõe, a pesquisa pode ser considerada descritiva, investigativa e exploratória e pesquisa aplicada.

A Figura 4 apresenta 0 desenho da pesquisa, destacando seus componentes e métodos, de acordo com suas três fases principais de desenvolvimento: (i) exploratória e descritiva; (ii) pesquisa aplicada; e (iii) conclusiva. Quanto aos meios de investigação, a metodologia compreende:

- Pesquisa bibliográfica, documental e experimental;

- Estudo do método de limpeza de trocadores de calor, que utiliza esferas abrasivas podendo ser aplicada em nível industrial, com baixo impacto econômico, curto tempo de aplicação e com eficácia, por meio de estudos de artigos relacionados aos métodos convencionais de limpeza;

- Pesquisa das patentes/registros de sistemas que utilizam o método de limpeza escolhido;

- Definição de incerteza e avaliação da confiabilidade metrológica de um sistema alternativo de limpeza de trocadores de calor.

Detalham-se, a seguir, as três fases da pesquisa e os resultados esperados em cada bloco da Figura 4. 


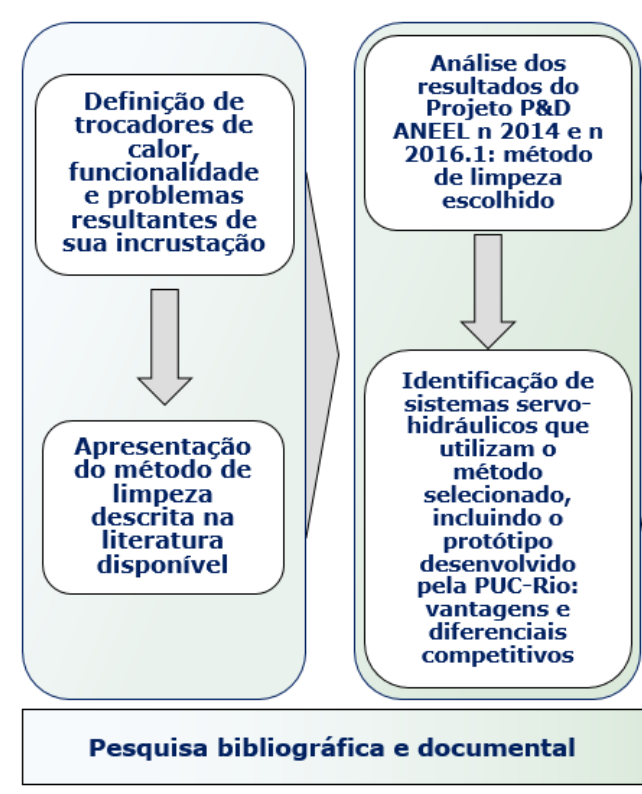

Fase 1 - Exploratória e descritiva
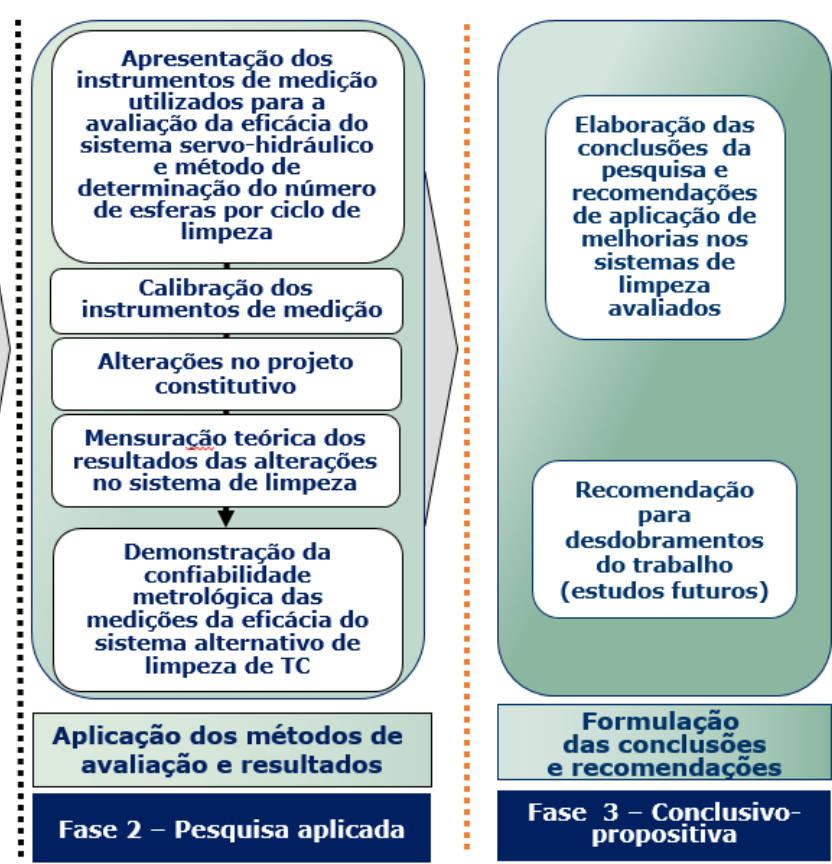

Figura 4 - Desenho da pesquisa, seus componentes e métodos

Do ponto de vista conceitual, esta seção caracteriza cada uma das três fases

de desenvolvimento da pesquisa identificadas na Figura 4, acima.

- Fase exploratória e descritiva - A pesquisa bibliográfica e documental constituiu-se no fundamento desta fase da pesquisa. Permitiu definir o referencial documental, bem como identificar patentes de sistemas de limpeza, assim delimitando o tema central da pesquisa. O estudo teve como foco a "avaliação metrológica de sistemas on-line de limpeza de trocadores de calor industriais, cujo funcionamento não interfere com a operação do sistema como um todo". Na sequência, aprofundou-se na revisão bibliográfica, buscando-se analisar os métodos de limpeza utilizados em escala industrial. Uma pesquisa nas bases de dados disponíveis relacionadas ao tema, notadamente dissertações anteriores desenvolvidas pelo Programa de Pós-graduação em Metrologia da PUCRio (Neves, 2013 e Oliveira, 2015), permitiu identificar as alternativas estudadas de limpeza e suas respectivas características técnicas e operacionais. Após a seleção do método mais adequado aos objetivos pretendidos, pesquisou-se uma base de dados especializada em patentes (Espacenet) visando identificar se existem sistemas similares que utilizam o método de limpeza escolhido. Essas patentes revelaram importantes informações sobre o funcionamento de cada um dos sistemas de limpeza identificados, o que permitiu orientar os esforços para o desenvolvimento de uma alternativa inovadora, distinta dos métodos existentes. $\mathrm{Na}$ sequência, uma comparação entre esses sistemas foi feita e o levantamento das vantagens e desvantagens de cada um deles foi realizada. A análise de funcionamento de cada alternativa foi elucidativa para explicitar as especificidades de cada proposta, seus ciclos de funcionamento, componentes, dimensões e instrumentação utilizada por cada um deles.

- Fase de pesquisa aplicada - Com o objetivo de demonstrar a aplicabilidade, funcionamento e acompanhamento da limpeza de cada uma das alternativas de limpeza estudadas, colocou-se em operação uma 
dessas alternativas de limpeza de um TC em campo de trabalho, em ambiente industrial, utilizado como estratégia de teste. Um arranjo de acoplamento foi desenvolvido para instalar o sistema ao TC, respeitandose todos os condicionantes impostos pelo ambiente de trabalho. As grandezas físicas pressão, temperatura e vazão do fluido de trabalho foram monitoradas e estudadas conforme a limpeza acontecia em tempo real, assim permitindo avaliar o desempenho global do sistema de limpeza investigado. Para atender aos propósitos do ensaio pretendido, todos os instrumentos utilizados na avaliação metrológica do sistema de limpeza foram previamente calibrados e sua rastreabilidade declarada. Os dados obtidos foram processados e avaliados estatisticamente, fundamentando as conclusões da avaliação realizada sobre a eficácia do método de limpeza investigado.

- Fase conclusivo - propositiva - Nessa terceira fase de desenvolvimento da pesquisa, as conclusões (geral e específicas) foram formuladas à luz das questões impostas pela presente pesquisa. Formulou-se ainda um conjunto de sugestões de temas de estudos acadêmicos futuros, entendidos como desdobramentos naturais desta pesquisa.

A Figura 5 apresenta o mapa conceitual da dissertação, que sintetiza as fases exploratória, descritiva, pesquisa aplicada, bem como a sua fase conclusivopropositiva.

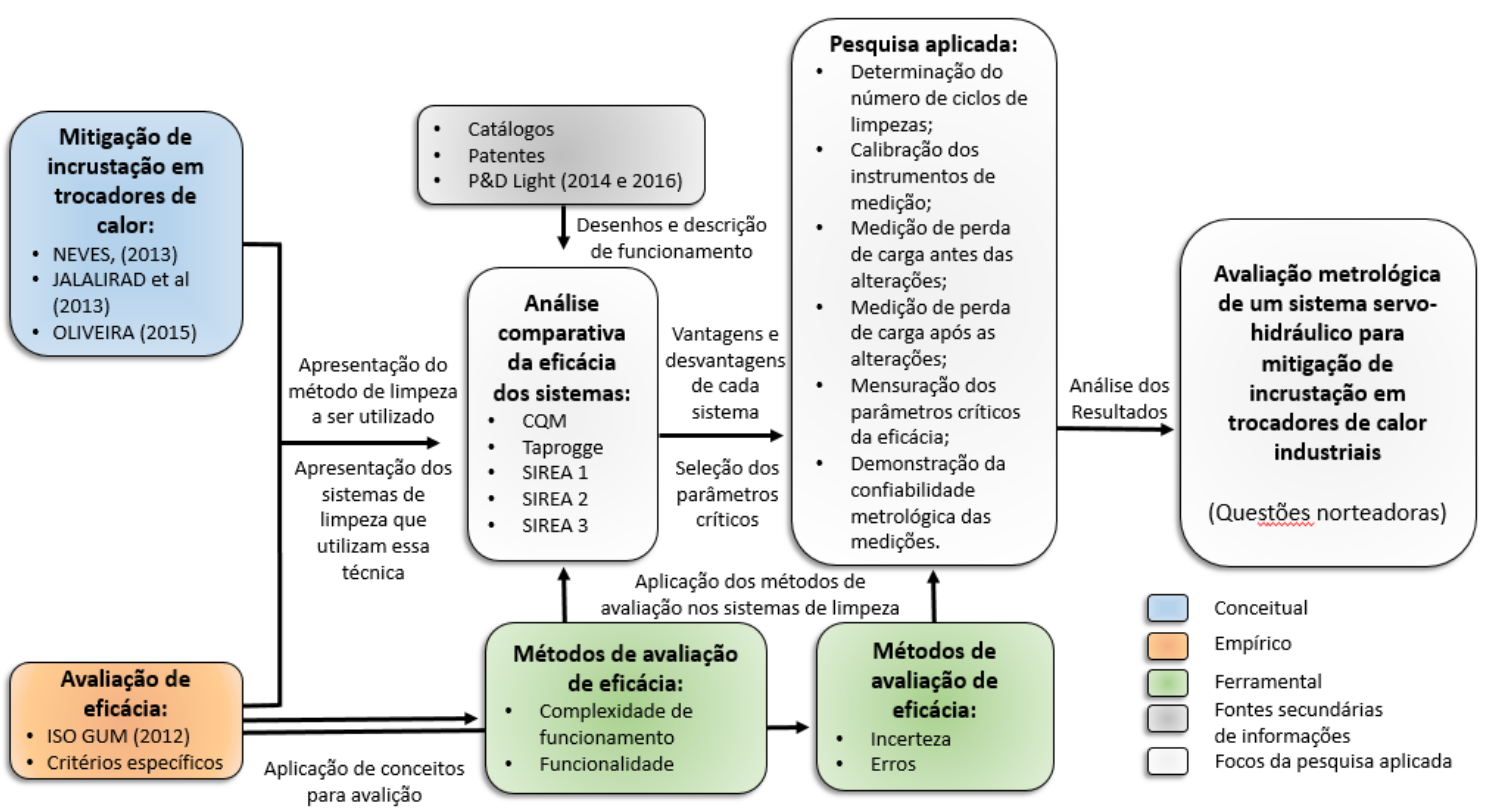

Figura 5 - Mapa conceitual da pesquisa

\section{4}

\section{Estrutura da dissertação}

A dissertação encontra-se estruturada em sete capítulos, incluindo esta introdução.

No Capítulo 2, desenvolvem-se a apresentação e os estudos do método de limpeza de um trocador de calor industrial, que faz uso de esferas abrasivas como artefatos de limpeza e descrevem-se e analisam-se alguns sistemas de limpeza de trocadores de calor disponíveis no mercado. As características, vantagens e 
desvantagens de cada sistema são discutidas nesse capítulo. Descrevem-se e analisam-se os dispositivos de limpeza de trocadores de calor desenvolvidos pelo Programa de Pós-Graduação em Metrologia da PUC-Rio, alternativas, essas, que fazem uso de esferas abrasivas como artefatos de limpeza. As características, vantagens e desvantagens de cada sistema são discutidas nesse capítulo.

No Capítulo 3, são caracterizados os procedimentos utilizados para se garantir o perfeito funcionamento do sistema de limpeza em operação e assegurar a sua total estanqueidade nas soldas e conexões do sistema construído. Ainda neste capítulo é proposto um modelo estatístico que visa identificar o número mínimo de ciclos de limpeza para garantir que todos os tubos do trocador de calor sejam visitados por pelo menos uma esfera abrasiva, uma única vez.

No capítulo 4, são discutidos os procedimentos de operação dos instrumentos utilizados para medir as grandezas de interesse durante o processo de limpeza do trocador de calor. O capítulo discute, também, aspectos da confiabilidade metrológicas das medições realizadas.

No capítulo 5, apresentam-se as modificações de projeto realizadas no sistema de limpeza para assegurar melhorias de desempenho operacional e redução da perda de carga. Tramos hidráulicos críticos foram monitorados para avaliar os resultados obtidos com as modificações realizadas no sistema de limpeza, cujos resultados são discutidos no capítulo.

Finalmente, no capítulo 6 , formulam-se as conclusões da pesquisa e endereçam-se propostas para estudos futuros, como desdobramentos naturais e aprofundamento de aspectos relevantes que emergiram desta dissertação. 


\section{2 \\ Estudo de artefatos e dispositivos de limpeza de trocadores}

Este capítulo estuda o artefato de limpeza proposto e alternativas de técnicas de limpeza de trocadores de calor.

\section{1}

\section{Artefatos de limpeza}

O método de limpeza descrito nesse capítulo utiliza esferas abrasivas como artefato de limpeza. Este é um método on-line (i.e.: o trocador de calor é submetido ao processo de limpeza sem a interrupção do processo industrial que faz uso do trocador). Durante o processo de limpeza, utiliza o próprio fluido de trabalho do trocador para fazer circular as esferas abrasivas pelo interior de seus tubos, o que permite remover as incrustações que se acumulam durante a operação de limpeza. A Figura 6 ilustra o processo de limpeza (Fig. 6a) que resulta da ação de uma das esferas em movimento e a eficácia da ação da esfera enquanto artefato de limpeza (Fig. 6b), quando testada em um trocador de calor utilizado para arrefecimento de um hidrogerador. Esse método foi amplamente estudado no curso de desenvolvimento de uma série de projetos de P\&D do Programa de PósGraduação em Metrologia da PUC-Rio (Frota et al., 2017, 2019), no âmbito dos quais, Neves (2013) e Oliveira (2015) desenvolveram suas pesquisas de mestrado. Jalalirad et al. (2013) e Abd-Elhady et al. (2015) estudaram aspectos relacionados à eficácia do processo de limpeza em função de características da esfera utilizada.

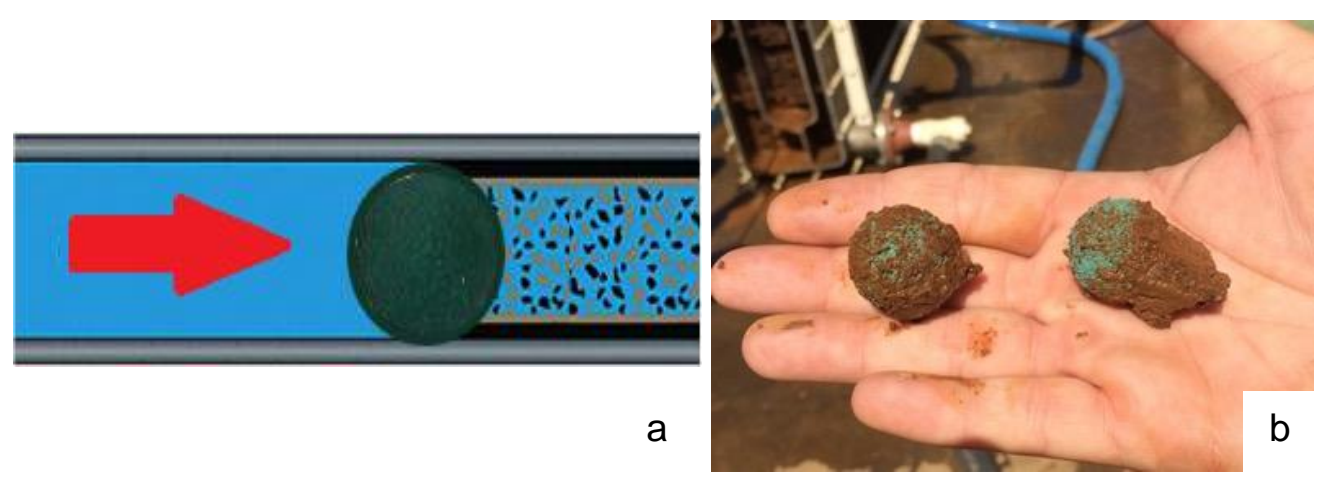

Figura 6 - Método (a) e eficácia (b) da limpeza por esfera abrasiva

Fonte: Oliveira, 2015

A esfera utilizada como artefato de limpeza é geralmente fabricada de material polimérico (material sintético, esponjoso, de baixa densidade e permeável). A porosidade do material esponjoso facilita a penetração da água no seu interior, o que contribui para que a densidade da esfera se aproxime da densidade da água, facilitando o seu transporte no meio aquoso. A Figura 7 
apresenta um exemplo de esfera abrasiva cortada transversalmente, assim tornando possível observar o seu interior.

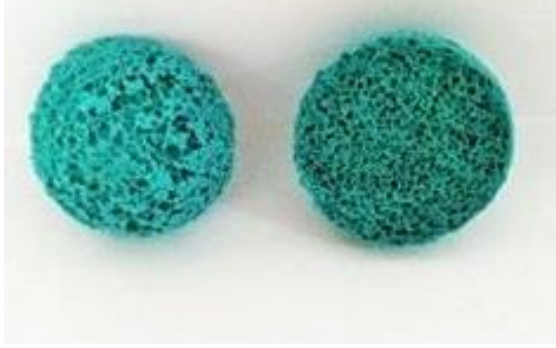

Figura 7 - Esfera típica utilizada para limpeza dos tubos do TC Fonte: Oliveira, 2015

Oliveira (Oliveira et al., 2015, 2017) relatam resultados de diversos ensaios realizados para se determinar propriedades mecânicas relevantes do artefato de limpeza (e.g.: rigidez e capacidade de absorção), visando orientar o processo de fabricação da esfera adequando-a para remover um determinado tipo de incrustação.

\subsection{1}

\section{Critério para definição do diâmetro da esfera utilizada na limpeza}

O diâmetro da esfera (artefato de limpeza) é crítico para assegurar eficácia do processo de limpeza. Esfera com diâmetro muito maior que os diâmetros internos dos tubos impacta na pressão hidráulica requerida para movimentar o artefato no circuito hidráulico do processo de limpeza, podendo, inclusive, obstruir alguns dos tubos do TC. Utilizar esferas com diâmetro expressivamente menor que os diâmetros dos tubos também não é recomendado para esta técnica, já que, ao se movimentarem, podem "martelar" a incrustação contra a parede, tornandoa ainda mais aderente à superfície da parede interna do tubo. A experiência tem mostrado que o diâmetro recomendável é aquele que apresenta uma pequena interferência (entre $5 \%$ e a 10 \%) com o diâmetro do tubo; ou seja, o diâmetro da esfera deve ser ligeiramente maior que o diâmetro do tubo submetido ao processo de limpeza, assim imprimindo um efeito de "limpeza por escovamento" suave, sem que a esfera fique presa no interior do tubo. O percentual de interferência deve ser definido em função da força de compressão da esfera utilizada; enquanto as mais rígidas devem ser colocadas em circulação com cerca de $5 \%$ de interferência, as menos rígidas com cerca de 10 \% (Jalalirad et al., 2013).

O diâmetro de amostras das esferas utilizadas como artefato de limpeza de trocadores de pequeno porte (diâmetro nominal de $16 \mathrm{~mm}$, caracterizado pelo 
fabricante) foram individualmente medidos por meio de um paquímetro (com resolução de $0,05 \mathrm{~mm}$, revelando que o diâmetro da esfera pode variar entre 17,00 $\mathrm{mm}$ e 18,25 mm, aqui explicitando-se que esses valores de diâmetro denotam a leitura do paquímetro, já que não faz sentido relatar o diâmetro de esferas esponjosas, macias, com resolução de centésimo de $\mathrm{mm}$, uma vez que as esferas não possuem esfericidade uniforme e que facilmente se deformam com um leve toque da haste da base de medição do paquímetro).

A Figura 8 resume o resultado do ensaio de encharcamento, que resultou do experimento de "afogamento" da esfera em água (fluido de trabalho do trocador), com o propósito de identificar o diâmetro máximo (diâmetro de saturação) na condição de esfera totalmente encharcada. O resultado da Figura 10 refere-se ao caso da esfera que apresentou a dimensão máxima $(18,25 \mathrm{~mm})$ de diâmetro, de um total de 6 esferas ensaiadas em um intervalo de tempo de 10 horas de observação.

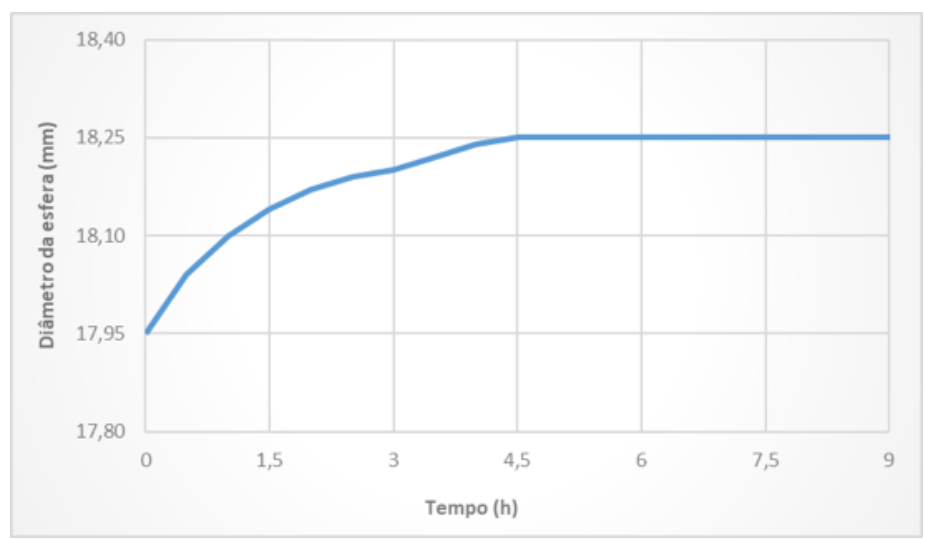

Figura 8 - Tempo de encharcamento da esfera

Como estratégia de se especificar a bomba hidráulica requerida para colocar as esferas em circulação com uma velocidade que assegura eficácia do processo de limpeza para o tipo de fouling estudado, Okouchi et al. (1983), os autores relatam resultados experimentais que permitem determinar a pressão de bombeamento em função da relação entre o diâmetro do tubo e o da esfera, conforme mostrado no gráfico da Figura 9. Pode-se apreender desses resultados que, quanto maior for a interferência adotada, maior será a pressão da bomba requerida para impor à esfera a velocidade desejada (no caso $1 \mathrm{~m} / \mathrm{s}$ ). 


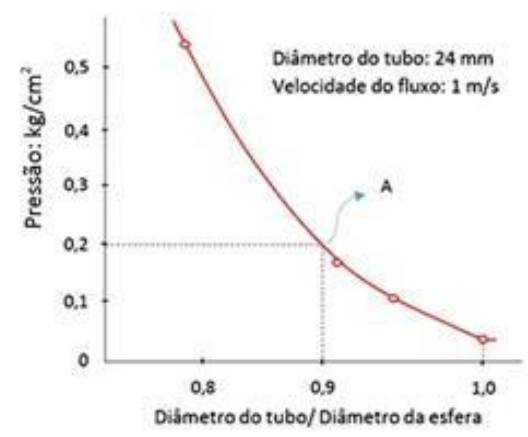

Figura 9 - Efeito do diâmetro da esfera na pressão do fluido

Fonte: adaptado de Okouchi e colaboradores (1983)

\subsection{2}

\section{Influência da velocidade da esfera no processo de limpeza}

A velocidade de circulação das esferas no interior dos tubos do trocador de calor constitui-se em parâmetro relevante para se assegurar eficácia do processo de limpeza. Bott (1995, p. 413) relata experimentos realizados para determinar os limites ideais de velocidade para se conseguir este objetivo. O fluido utilizado nesses experimentos foi a água e os resultados dos experimentos mostraram que valores de velocidade:

- abaixo de $1 \mathrm{~m} / \mathrm{s}$ não propiciam um processo eficaz de limpeza e favorecem a formação de novas incrustações já que a incrustação residual não removida age no sentido de reduzir o tempo de incubação em que a incrustação não se cristaliza nas paredes internas do tubo;

- entre $1 \mathrm{~m} / \mathrm{s}$ e $2 \mathrm{~m} / \mathrm{s}$ asseguram eficácia do processo de remoção de incrustações nos tubos;

- muito acima de $2 \mathrm{~m} / \mathrm{s}$ também se mostraram eficazes na remoção de incrustações. Contudo, dependendo do material do tubo, velocidades mais elevadas podem comprometer a integridade da superfície interna do tubo submetido à limpeza, contribuindo para acelerar o processo de erosão da superfície do tubo que se deseja limpar.

Em seu estudo sobre trocadores de calor, Bott (1995) discute, também, a influência da temperatura do fluido de trabalho do TC no resultado do processo de limpeza. Em experimentos em que a esfera circulava a uma mesma velocidade em torres de refrigeração que utilizam água como fluido de trabalho, o processo mostrou-se mais eficaz quando a torre operou com água mantida a $7^{\circ} \mathrm{C}$, quando comparado a experimento similar com a torre operando com a temperatura da água em $20^{\circ} \mathrm{C}$. Esse é um resultado que, entretanto, não pode ser generalizado, provavelmente aplicável ao caso de incrustações de natureza orgânica, em que proliferação de microrganismos ocorre de maneira mais intensa em temperaturas mais elevadas. Muito provavelmente, o oposto deve ocorrer para incrustações de natureza inorgânica. 


\subsection{3}

\section{Influência da rigidez da esfera abrasiva}

Quando a esfera abrasiva circula pelo interior do tubo que se deseja desobstruir na condição com interferência (i.e.: diâmetro da esfera ligeiramente maior que o diâmetro do tubo), a esfera exerce uma força de compressão circunferencialmente distribuída na parede interna do tubo. Considerando-se um balanço de forças na esfera, esta é submetida a uma força de compressão, de mesmo módulo e direção, mas sentido contrário, à direção normal à superfície da esfera e igualmente distribuída ao longo da circunferência de contato da esfera. Já o deslocamento da esfera transportada pelo fluido viscoso (água de resfriamento do trocador de calor) impõe à esfera uma força viscosa (força de cisalhamento), que atua na parede, na direção contrária ao escoamento. Assim, para que a bomba consiga colocar a esfera em movimento, a pressão do fluido a montante (da esfera) precisa produzir uma força (pressão a montante multiplicada pela área da seção projetada da esfera, ou pela área da seção reta do tubo na situação de esfera com interferência) superior à soma da força de atrito (produto da força normal circunferencial multiplicada pelo fator de atrito $\mu$ ) com a força viscosa (produto da tensão de cisalhamento, calculada pelo gradiente de velocidade na parede multiplicada pela área em que atua). Este balanço de forças é determinante para se definir a potência do grupo motor bomba a ser selecionado para impulsionar o fluido de trabalho (meio de transporte das esferas abrasivas) pelos tramos do dispositivo de limpeza. Já a sua rigidez define-se pela sua capacidade de resistir à deformação. Nesse contexto, esses fatores se constituem em parâmetros relevantes para se especificar o material mais adequado para se fabricar uma esfera que objetiva uma ação de limpeza eficaz nos tubos do TC.

Considerando-se esferas constituídas de mesmo material, quanto maior a interferência do diâmetro da esfera com o diâmetro interno dos tubos, maior é a força aplicada sobre a esfera, o que demanda uma maior potência da bomba hidráulica para impulsionar o fluido de trabalho para deslocar o artefato no interior dos tubos. Caso a bomba hidráulica não forneça energia suficiente ao fluido para transportar as esferas por todo comprimento do tubo a ser limpo, ocorrerá, indesejavelmente, o encalhamento dos artefatos de limpeza no interior do tubo.

O experimento mostrado na Figura 10 foi concebido para se determinar a rigidez do material da esfera. Uma esfera (uma amostra de um lote de esferas) foi introduzida entre os discos da máquina de ensaio universal (INSTRON, 5500R, classe de erro máximo de $0,5 \%$ ) utilizada para realizar o ensaio. $O$ ensaio consistiu em submeter a esfera a uma força de compressão desde o seu estado 
de repouso (compressão zero) até a condição em que a esfera foi comprimida até a metade de seu diâmetro, sistematicamente registrando-se os valores da força de compressão necessária para deslocar a esfera e o valor desse deslocamento experimentado pela esfera. Esse ensaio foi realizado no Laboratório de Ensaios Mecânicos (LEM) da PUC-Rio.

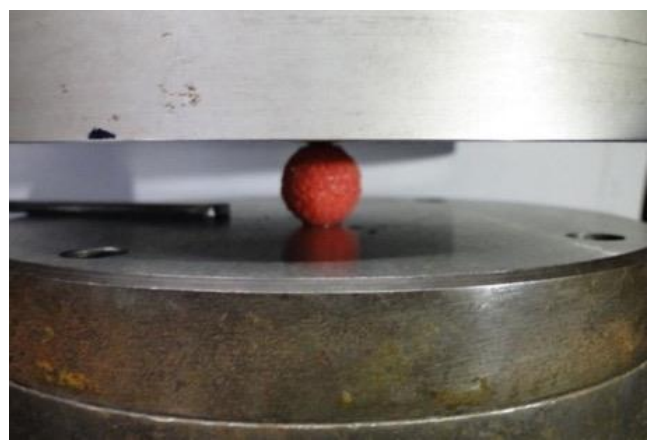

Figura 10 - Esfera abrasiva submetida ao ensaio de compressão

Os ensaios de compressão foram realizados com 16 esferas, 8 secas e 8 totalmente encharcadas, estas últimas para reproduzir na máquina de ensaios a condição real da esfera quando em operação no sistema de limpeza, já que o fluxo de água (fluido de trabalho do trocador de calor) é o meio de transporte da esfera no interior dos tubos submetidos ao processo de limpeza. Para efeito do cálculo do módulo de elasticidade da esfera, foram consideradas as médias dos valores obtidos para cada grupo de esferas (secas e encharcadas). O valor de cada força de compressão obtida no ensaio, dividido pela respectiva área da seção transversal da esfera em seu estado natural (i.e., sem ser comprimida), fornece a tensão de compressão instantânea atuante na esfera submetida ao ensaio (o valor da tensão de compressão da esfera aumenta à medida que se aumenta o esmagamento da esfera entre os planos das plataformas da máquina de ensaios Instron de contato com a esfera). Para cada ensaio de compressão realizado, o deslocamento do travessão que comanda a plataforma da máquina de contato com a esfera foi normalizado no diâmetro da esfera em seu estado natural. Resultante dessa normalização e desse procedimento de ensaio, determina-se a deformação da esfera em cada momento do ensaio. A razão entre a tensão (razão entre a força de compressão pela área da esfera em repouso, expressa em MPa) e a deformação normalizada (expressa em $\mathrm{mm} / \mathrm{mm}$ ) resulta no valor do módulo de elasticidade (E) da esfera ensaiada. As Figuras 11 e 12 resumem os resultados dos ensaios realizados, respectivamente, para as esferas secas e ensaiadas. Para cada caso, os valores apresentados referem-se à média dos valores obtidos para as oito esferas ensaiadas. O módulo de elasticidade (E, expresso em MPa) do 
material da esfera é então obtido pelo coeficiente angular das curvas tensãodeformação plotadas.

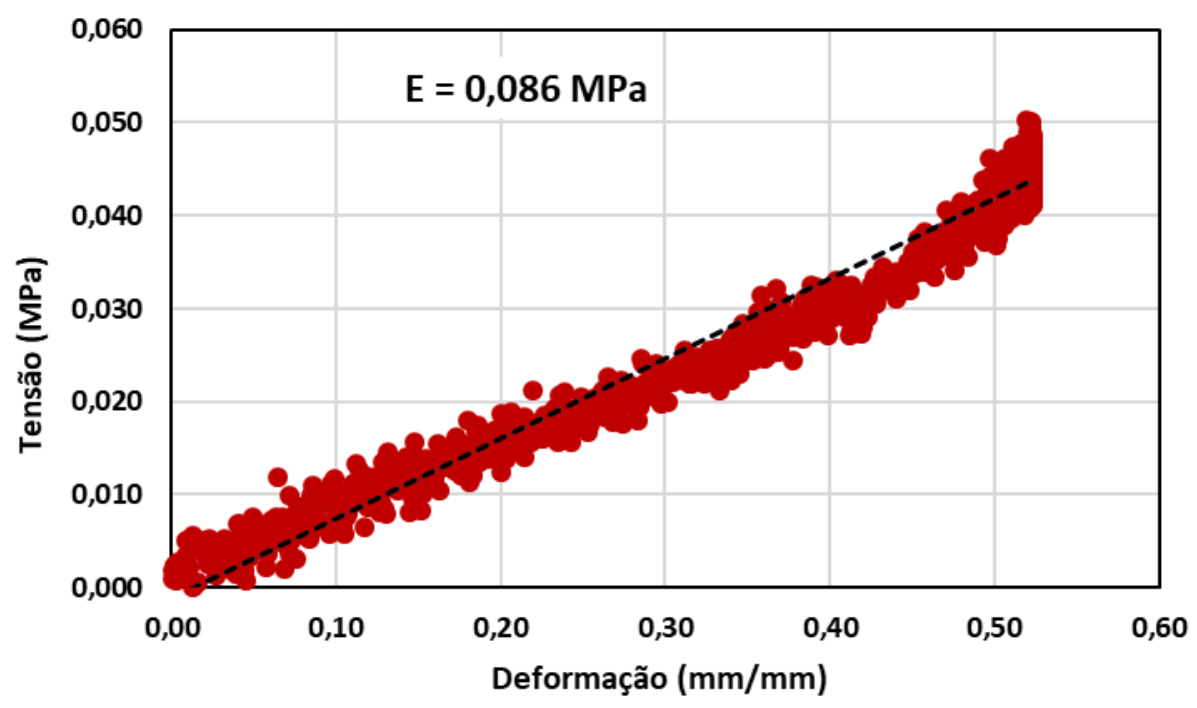

Figura 11 - Gráfico do módulo de elasticidade da esfera seca

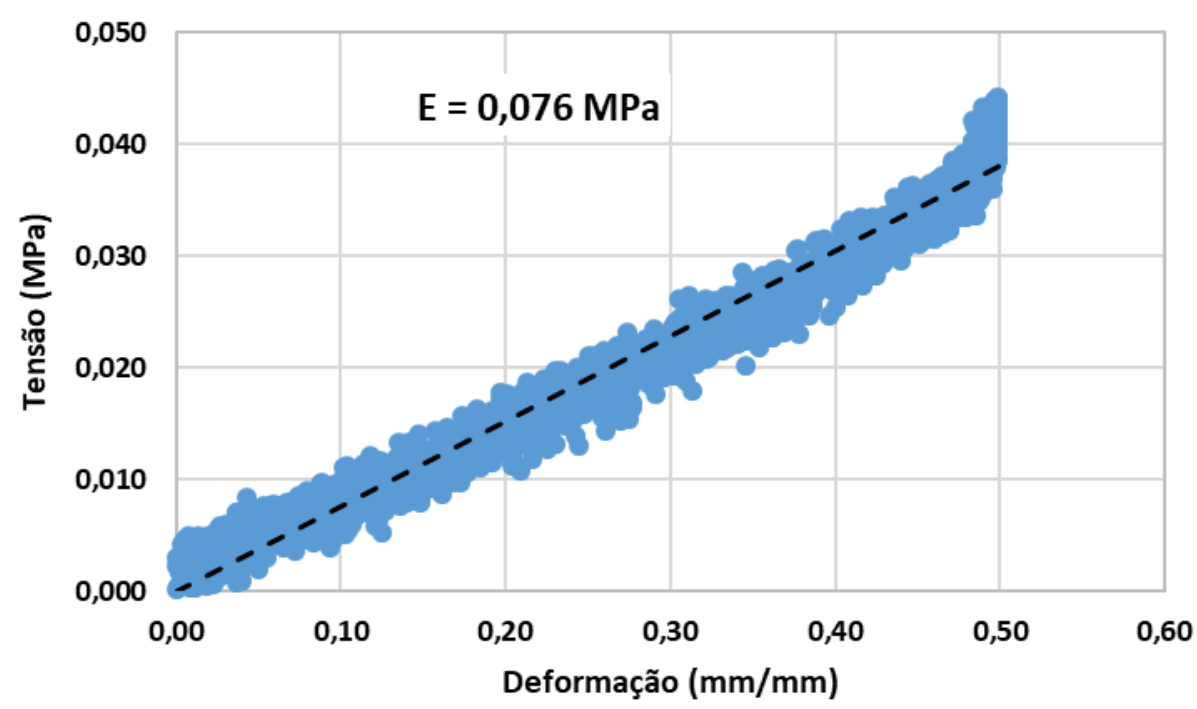

Figura 12 - Gráfico do módulo de elasticidade da esfera encharcada

As equações (1) e (2), respectivamente, apresentam os resultados dos ensaios realizados para determinação do Módulo de Elasticidade do material da esfera testada, nas condições seca e encharcada.

$$
\begin{aligned}
& E_{\text {seca }}=0,086 \mathrm{MPa} \\
& E_{\text {ench }}=0,076 \mathrm{MPa}
\end{aligned}
$$

Com base nos resultados nos dois ensaios realizados é possível determinar a rigidez: (i) 0,086 MPa, para a esfera seca (polímero e ar) e 0,076 MPa, para a 
esfera encharcada (polímero e ar). A presença da água (fluido incompressível) concede à esfera encharcada um aumento da força de compressão em relação à situação da esfera seca, preenchida com ar (fluido compressível). A Figura 13 apresenta, para os dados experimentais realizados, o aumento da tensão (MPa) com a deformação adimensionalizada para ambos os ensaios realizados com esfera seca (E seca) e esfera encharcada (E ench).

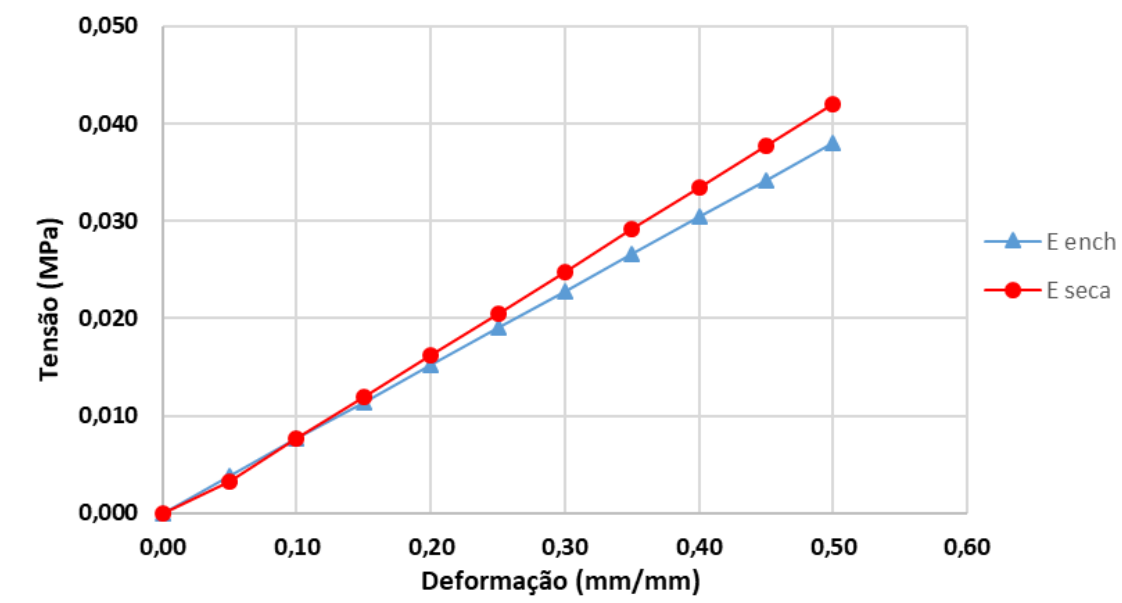

Figura 13 - Gráfico de comparação da rigidez das esferas seca e encharcada

\subsection{4}

\section{Força de atrito atuante na esfera ao se movimentar no tubo do TC}

Como é necessário impulsionar a esfera pelo interior dos tubos do TC com um certo grau de interferência (diâmetro da esfera ligeiramente maior que o do tubo, cerca de $10 \%$ ) esta, fica submetida a uma força de atrito, que atua na mesma direção do seu movimento, porém no sentido oposto.

A especificação (seleção) da bomba hidráulica a ser utilizada para movimentar o fluxo de água que transporta a esfera abrasiva pelo interior dos tubos a serem submetidos ao processo de limpeza requer o cálculo das forças que precisarão ser vencidas para colocar a esfera em movimento, mais precisamente da soma da força de atrito estático (produto da força normal pelo coeficiente de atrito) e da força viscosa (produto da tensão na parede pela área em que atua). Conhecidas essas forças, determina-se a pressão mínima que a bomba deve imprimir no escoamento (soma dessas forças multiplicada pela área da seção transversal do tubo).

As equações (3) e (4), da Mecânica Clássica, definem essas forças de atrito e viscosa:

$$
F_{\text {atrito }}=\mu . N
$$




$$
F_{v i s c o s a}=v(d u / d r) .(\text { Área de contato) }
$$

Nessas expressões, $\mu$ denota o Coeficiente de atrito estático; $N$ a força normal exercida sobre a esfera; $v$ a viscosidade do fluido que transporta a esfera e $\left.\frac{d u}{d r}\right)$, o gradiente de velocidade $u$, na direção do escoamento, calculado na parede $\left(r=r_{0}\right)$.

Oliveira et al. (2016) realizaram experimentos para medir a força máxima de atrito entre a superfície de contato da esfera abrasiva com a superfície interna do tubo do TC, para diferentes graus de incrustação. As características da esfera e dos tubos do TC utilizados nos experimentos realizados por Oliveira et al. (2017) foram relatados em trabalho publicado pelos mesmos autores no IX Congresso Brasileiro de Metrologia (2019). A medição da força de atrito que produz a iminência do movimento da esfera foi medida com o auxílio de um dinamômetro calibrado, na faixa 0 a $5 \mathrm{~N}$. O experimento consistiu em arrastar a esfera no interior do tubo do TC até que ocorra a iminência de seu deslizamento (Figura 14 b). A esfera foi presa ao dinamômetro por meio de um fio de nylon rígido (Figura a), assim conseguindo-se medir a força máxima de atrito $\left(F a t_{\text {máx }}\right)$, experimento esse que foi repetido em diversos tubos com diferentes graus de incrustação, conforme ilustrado na Figura 14.

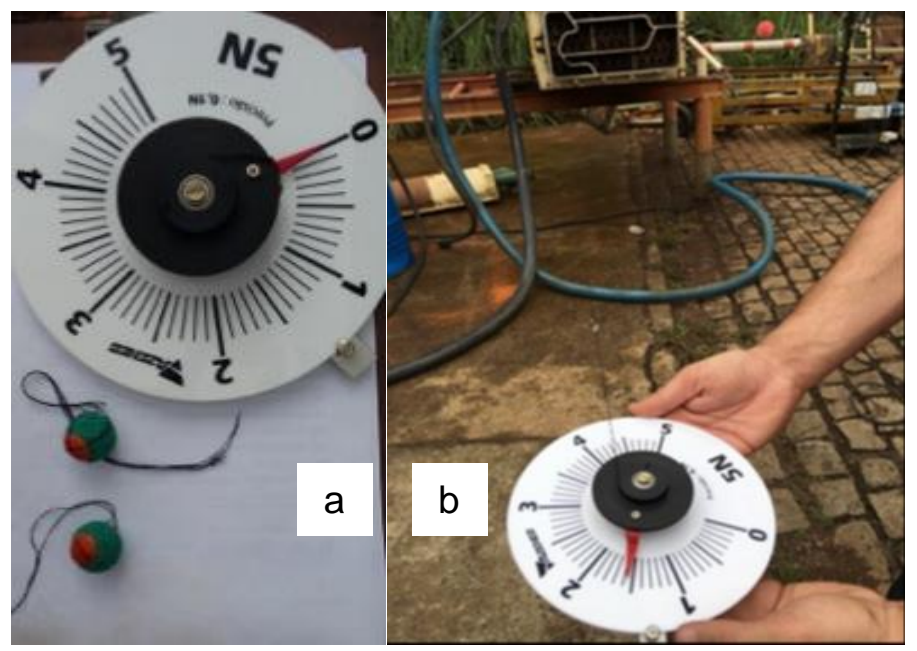

Figura 14 - Arranjo experimental (a) utilizado para medição da força de atrito máximo (b) Fonte: Oliveira, 2015 e Oliveira et al., 2017

\section{2}

\section{Dispositivos comerciais de limpeza}

Dentre as alternativas tecnológicas utilizadas para realizar a limpeza de trocadores de calor (TC) de equipamentos industriais, a mais comumente empregada é a limpeza manual (offline), que requer a desmontagem do trocador 
para permitir acesso interno e a limpeza mecânica de seus dispositivos de troca de calor (tubos ou placas). Extensa revisão da literatura sobre as possíveis técnicas de limpeza encontra-se documentada na literatura especializada (Bott, 1995; Bott, 1996; Bott, 1997 e Bott, Melo, 1997 e Frota et al., 2014).

Não obstante eficazes, os métodos manuais de limpeza demandam expressivo tempo de manutenção, podendo colocar em risco o trocador, já que requerem a parada técnica do equipamento principal acoplado ao trocador e remoção do trocador para o pátio externo de limpeza, resultando, portanto, em perdas econômicas que decorrem da complexa interrupção da operação.

No contexto desse esforço de pesquisa, foram estudadas as alternativas de limpeza que fazem uso de artefatos de limpeza para remover a incrustação, artefatos esses transportados pelo próprio fluido de trabalho do trocador. Estudo da literatura especializada mostrou que existem algumas variações dessa técnica, cada qual com suas vantagens e limitações.

Assim, antes de apresentar a alternativa de limpeza de trocadores de calor desenvolvida pelo Programa de Pós-Graduação em Metrologia da PUC-Rio, discutem-se, a seguir, as características funcionais e as desvantagens de dois sistemas de limpeza identificados na literatura: Taprogge e sistema ATCS.

\subsection{1}

\section{Sistema Taprogge de limpeza de trocador de calor}

O sistema desenvolvido pela empresa alemã Taprogge $\mathrm{GmbH}$ para equipamentos de grande porte é capaz de injetar esferas abrasivas no fluxo da água de operação do trocador de calor e de recolher as esferas após estas terem realizado a limpeza das superfícies internas dos tubos do trocador de calor. O sistema Taprogge constitui-se em um sistema fechado, de grande porte (notadamente para aplicação em trocadores de calor de usinas termoelétricas e nucleares).

A Figura 15 ilustra uma instalação típica em trocadores de calor de uma usina termoelétrica, que emprega o sistema Taprogge, utilizado na limpeza de trocadores de calor. 


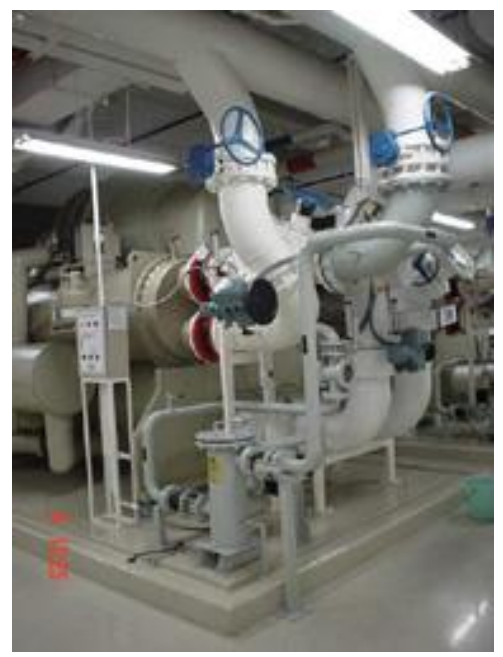

Figura 15 - Instalação típica do sistema Taprogge

Fonte: www.blackseagroup.com/supply.html

Conforme mostrado na Figura 15, o sistema Taprogge requer área considerável para sua instalação, somente assim conseguindo acomodar as tubulações utilizadas para conectar o sistema de limpeza ao trocador de calor. Devido ao grande porte das tubulações, esferas abrasivas frequentemente se perdem no fluxo de descarga, podendo contaminar o leito dos rios (existem relatos de ativistas do meio ambiente de que tartarugas marinhas foram encontradas mortas com esferas abrasivas em seu sistema digestivo). Este é um sistema central, fixo, de grande porte, exclusivamente dedicado à instalação para o qual foi concebido.

O esquemático da Figura 16 mostra os principais elementos que constituem o sistema de limpeza Taprogge, que utiliza a própria água de arrefecimento (um dos fluidos de trabalho do trocador de calor) para transportar o artefato de limpeza. A figura ilustra o funil de recuperação das esferas, instalado no interior de uma tubulação de grande porte, cuja vedação junto à parede nem sempre garante a recuperação de todas as esferas. 


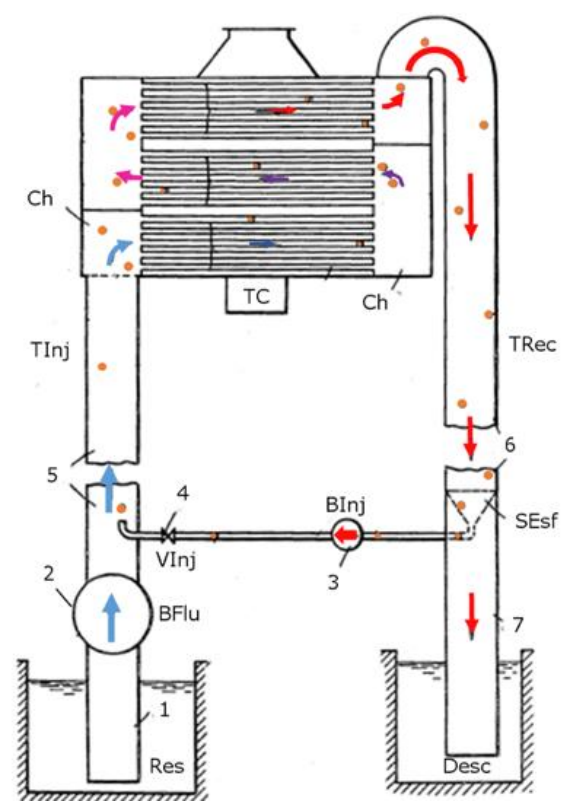

Figura 16 - Esquemático Taprogge

Fonte: Adaptado de Taprogge (1962)

São eles:

- Res - Reservatório de água de operação do sistema de limpeza;

- $B_{F l u}-$ Bomba hidráulica geradora do fluxo principal do sistema;

- $B_{l n j}$ - Bomba centrífuga de rotor aberto de injeção de esfera;

- $\quad V_{I n j}-$ Válvula do fluxo de água de transporte (injeção) de esfera;

$T_{\text {Inj }}$ - Tramo de injeção de esfera;

- TC-Trocador de calor;

- Ch-Chicana do trocador de calor;

- $T_{R e c}-$ Tramo de recuperação de esfera;

- $S_{E s f}-$ Separador de esfera;

- Desc - Descarga de água de operação;

- 1 - Passagem de água de operação utilizada pelo sistema de limpeza;

- 2 - Bomba hidráulica geradora do fluxo de água de transporte das esferas utilizadas pelo sistema;

- 3 - Subsistema: bomba hidráulica de injeção e selecionador de esfera;

- 4 - Válvula responsável pela injeção da esfera no fluxo principal do sistema de limpeza;

- 5 - Esfera se junta ao fluxo principal para ser inserida no TC e realizar a limpeza dos tubos;

- 6 - Seção da tubulação por onde a esfera retorna do TC após remover incrustações;

- 7 - Água de operação após passar pelo TC.

Nota: Potência elétrica da $B_{F l u}>B_{l n j}$.

Na Figura 18, as setas indicam o fluxo da água de resfriamento do sistema. Neste esquemático, as esferas abrasivas utilizadas como artefatos de limpeza dos tubos do trocador de calor são representadas pelos símbolos na cor laranja. Os números e as abreviações destacam partes integrantes do sistema. 
O funcionamento do sistema Taprogge inicia-se com o fluxo de água principal gerado pela bomba hidráulica identificada por $B_{F / u}$ no esquemático da Figura 2. Na sequência de operação, a bomba $B_{l n j}$ injeta a esfera no fluxo principal, de acesso ao interior do trocador de calor, visando realizar a limpeza do interior de seus tubos. Quando deixa o trocador após o desejado processo de limpeza, a esfera é recolhida pelo separador e fica retida no aguardo para ser novamente injetada no fluxo principal, assim dando início a um ciclo subsequente de limpeza.

Como mostrado, o sistema Taprogge possui peculiaridades em seu funcionamento que the confere pontos de vantagens e desvantagens. Alguns desses pontos são apresentados:

Vantagens:

- Robustez do sistema;

- Baixo número de válvulas de controle de fluxo;

- Capacidade de operar em tempo contínuo.

Desvantagens:

- Necessidade de duas bombas hidráulicas $\left(B_{F l u}\right.$ e $\left.B_{\mid n j}\right)$;

- Fluxo de água durante a limpeza é dado exclusivamente por $B_{F l u}$, que pode não fornecer velocidade ideal capaz de assegurar eficácia do processo de limpeza;

- $B_{I n j}$ possui a única função de introduzir a esfera no fluxo principal, função factível ser substituída por outro dispositivo, assim evitandose mais uma bomba hidráulica (que requer manutenção) no sistema;

- Esfera passa pelo interior rotor da bomba hidráulica $\left(B_{I_{n j}}\right)$, certamente reduzindo a vida útil da esfera;

- Ausência de dispositivo de verificação de esfera retida no TC (não dispõe de contador de esfera);

- Falta de especificação sobre o número ótimo de esferas a serem usadas em um ciclo de limpeza do TC;

- $S_{E s f}$ é um componente móvel, ou seja, sofre desgaste;

- Sistema Taprogge requer considerável espaço físico no ambiente de sua instalação;

- Sistema Taprogge é estático, ou seja, não pode ser transferido para outras áreas;

- Tubulações do sistema são rígidas, transferindo para o sistema vibrações do equipamento submetido ao processo de limpeza;

- Sistema Taprogge requer intervenção na tubulação local para instalação de seu sistema de limpeza.

O sistema Taprogge possui a capacidade de funcionar continuamente, pois as esferas são injetadas passando pelo $\left(B_{\mid l n}\right)$, i. e. pelo interior do rotor da bomba, o que, comumente, danifica a esfera. Caso $B_{l n j}$ esteja continuamente em funcionamento, a esfera é automaticamente injetada no fluxo principal, após passar pelo separador.

Uma das deficiências do sistema Taprogge é a falta de um dispositivo de controle que permita indicar se alguma esfera ficou presa no interior dos tubos do 
trocador de calor. O sistema Taprogge não faz nenhuma referência sobre o total de esferas abrasivas a serem carregadas no sistema para assegurar a eficácia do processo de limpeza. Entretanto, estudo realizado em 2007 por Müller-Steinhagen (2000), propõe um método para se determinar o número mínimo de esferas que deve ser utilizado para assegurar que todos os tubos do sistema sejam visitados durante o processo limpeza. Segundo o autor, este número mínimo de esferas pode ser estimado na ordem de $10 \%$ a $30 \%$ do número de tubos por passe do trocador de calor, dependendo do porte do trocador e da geometria das chicanas e dureza do material da esfera.

Dentre as limitações do sistema Taprogge de limpeza, destacam-se: (i) validado para sistemas de grande porte; (ii) risco de danificação das esferas pelo fato de estas circularem pelo interior do rotor da bomba $B_{l n j}$ e (iii) risco de algumas esferas não serem recuperadas e serem descartadas no meio ambiente (leito de rios e oceanos). Isso, sem dúvida, compromete a técnica e a integridade das esferas, pois ao passar pelo rotor estas podem se chocar com as pás do rotor, gerando desgaste que reduz a vida útil dos artefatos de limpeza. Embora $B_{\ln j}$ tenha um rotor aberto, que permite a passagem de grandes partículas, isso não garante que as esferas não sejam danificadas quando passam pelo rotor da bomba.

\subsection{2}

\section{Sistema ATCS de limpeza de trocador de calor}

A empresa israelense de nome Cooling Quality Management (CQM) é especializada em soluções ecológicas para água de tratamento de torres de refrigeração. A empresa atua em diversas áreas, inclusive na limpeza de trocadores de calor de sistemas de água gelada para condicionamento de ar, que operam com feixes tubulares. O sistema de limpeza de trocadores utilizado pela CQM é denominado pela própria empresa por Automatic Tube Cleaning System (ATCS). O sistema opera injetando e recuperando esferas no trocador de calor em sistema aberto, ou seja, as esferas seguem percursos diferentes dentro do ATCS de acordo com a operação de injeção e recuperação. O ATCS não é capaz de funcionar continuamente porque necessita realizar diferentes manobras de válvulas para injetar ou recuperar esferas. A Figura 17 mostra uma instalação típica. 


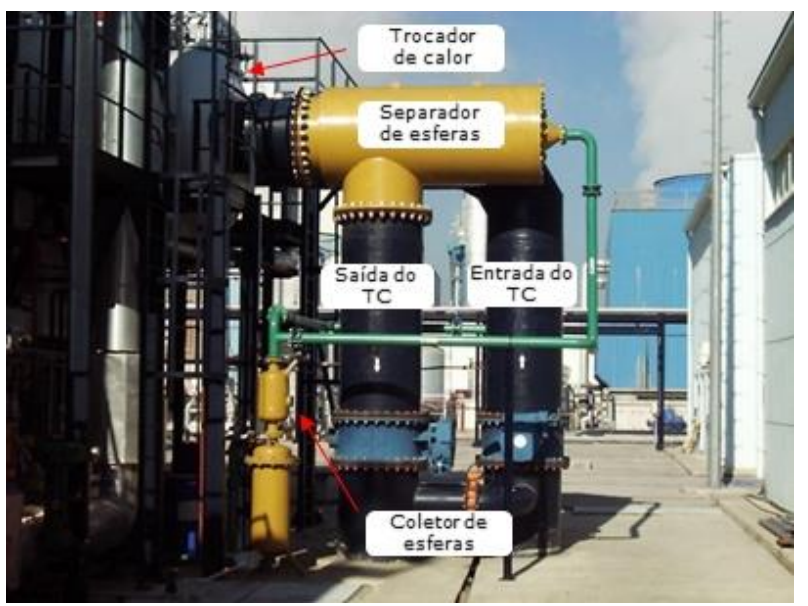

Figura 17 - Instalação típica de um sistema ATCS Fonte: Adaptado catálogo da empresa CQM

O esquemático da Figura 18 explica o funcionamento do sistema de injeção e recuperação de esferas, respectivamente $A$ e $B$, evidenciando os elementoschave do sistema de limpeza ATCS. Nesse esquemático, as esferas utilizadas como artefatos de limpeza dos tubos do trocador são representadas pelos símbolos em laranja.
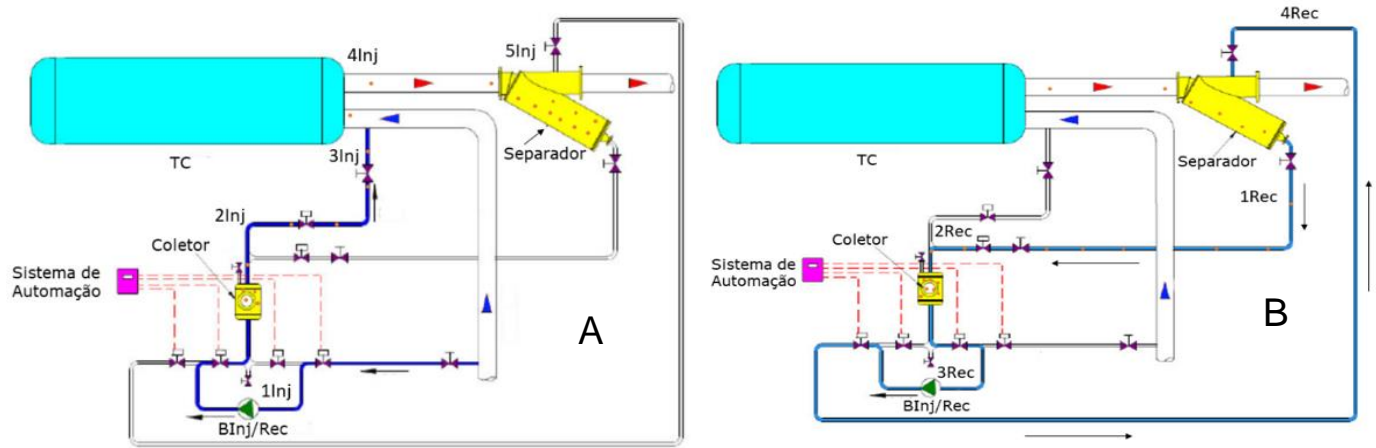

Figura 18 - Esquema ATCS (fluxos de processo de injeção $(A)$ e recuperação de esfera (B)) Fonte: Adaptado do catálogo da empresa CQM

As setas indicam o fluxo da água no sistema. Os números e as abreviações, a seguir decodificados, denotam partes integrantes do sistema. São eles:

- $B_{\operatorname{lnj} / R e c}$ - Bomba hidráulica auxiliar, de injeção e recuperação de esfera;

- TC-Trocador de Calor;

- $1_{l n j}$ - Parte do fluxo principal é extraído por $B_{l n j} / R e c$;

- $2_{l n j}$ - Fluxo gerado por $B_{l n j} / R e c$ retira a esfera do coletor e a leva para realizar a limpeza dos tubos do TC;

- $3_{n j}$ - Esfera é inserida no TC;

- $4_{\text {Inj }}$ - Esfera deixa o TC;

- $5_{l n j}-$ Esfera é retirada do fluxo principal e fica retida no separador;

- $1_{\text {Rec }}$ - Esfera deixa o separador;

- $2_{\text {Rec }}$ - Esfera é devolvida ao coletor; 
- $\quad 3_{R e c}$ - Fluxo gerado por $B_{I n j} / \operatorname{Rec}$ passa pela bomba, mas já sem a esfera;

- $4_{R e c}-$ Fluxo secundário se junta ao principal.

O sistema ATCS possui um coletor que aloja as esferas abrasivas quando não estão em circulação no trocador de calor. Válvulas solenoides são atuadas pelo sistema de automação permitindo direcionar parte do fluxo da água de operação por meio de uma bomba auxiliar de baixa potência. Essa água é oriunda do fluxo de operação principal que é gerado pelo sistema de arrefecimento que atua ininterruptamente e é independente do ATCS. O fluxo direcionado pela bomba auxiliar retira as esferas do coletor e a injeta no fluxo principal. Nesse momento a bomba auxiliar é desligada. Os artefatos seguem ao trocador de calor para realizar a limpeza de seus tubos. O separador retém as esferas, retirando-as do fluxo principal após a limpeza do trocador. Enquanto ocorre a manobra de válvulas, que permite a recuperação das esferas, estas permanecem retidas no separador. Quando a manobra de válvulas é terminada, a bomba auxiliar é religada e gera um fluxo que impulsiona os artefatos para o coletor.

Como mostrado, o sistema ATCS possui peculiaridades em seu funcionamento que the confere pontos de vantagens e desvantagens. Alguns desses pontos são apresentados:

Vantagens:

- Sistema de limpeza sem componentes móveis (com exceção da bomba hidráulica), o que evita o desgaste das demais peças do equipamento ATCS;

- Sistema mais sofisticado, monitorado e controlado eletronicamente;

- Supervisório IHM (Interface Homem-Máquina) acoplado ao sistema de automação, o que permite ao operador verificar se há alguma válvula e/ou bomba que apresenta falha durante o funcionamento do ATCS;

- Esferas não passam pelo rotor da bomba auxiliar.

Desvantagens:

- Bomba adicional $\left(B_{\text {Inj }} / R e c\right)$, utilizada apenas para inserir e recolher as esferas;

- Velocidade da água durante a limpeza é dada exclusivamente pelo fluxo principal que, não necessariamente, é capaz de assegurar a velocidade linear ideal de circulação $(2 \mathrm{~m} / \mathrm{s})$ das esferas, conforme sugerido por Bott (Bott, 1995);

- Ausência de dispositivo de verificação de esferas retidas no TC;

- Ausência de indicação que defina o total ótimo de esferas a serem introduzida no trocador de calor;

- Sistema de limpeza requer grande área no ambiente onde será instalado;

- Sistema de limpeza é fixo, ou seja, não pode ser transferido para outras áreas de trabalho; 
- Tubulações do sistema são rígidas;

- Instalação não trivial.

\section{3 \\ Dispositivos de limpeza proposto pelo PósMQI/PUC-Rio}

Contrastando com os sistemas apresentados nas seções 2.2.1 e 2.2.2, Frota e colaboradores (2014) ensaiaram a eficácia de uma técnica, não invasiva, objetivando remover a incrustação em trocadores de calor de placas verticais. Diferente das técnicas convencionais, a alternativa proposta consistiu em "excitar" o escoamento por meio de um campo elétrico externo, que favorecia o desprendimento de placas de incrustação, então removidas do trocador pela ação hidrodinâmica do próprio fluido de trabalho. Conforme relatado em publicação realizada em periódico especializado (Frota et al., 2014), analisando os resultados de inúmeros ensaios realizados em trocadores de calor água-óleo de placas planas verticais, utilizados para arrefecer os mancais de turbinas hidráulicas de eixo vertical, a técnica mostrou-se eficaz para mitigar o grau de incrustação, entretanto, não removendo totalmente a incrustação. Em outras palavras, embora a técnica seja capaz de postergar a parada técnica de limpeza ela não é capaz de eliminá-la.

$\mathrm{Na}$ busca de alternativas mais eficazes para eliminar o fouling e evitar a parada técnica de equipamentos, cujo funcionamento requer o uso de trocadores de calor, o Programa de Pós-Graduação em Metrologia da PUC-Rio criou uma linha de pesquisa para estudar o problema com vistas a propor alternativas tecnológicas mais eficazes de limpeza de equipamentos industriais. Como resultado deste esforço de pesquisa, já foram desenvolvidos 3 Projetos de $P \& D$ para o setor elétrico, todos eles devidamente documentados em relatórios de projetos de P\&D realizados (Frota, 2014; Frota, 2014 e Frota, 2018). Esses projetos desenvolvidos, geraram trabalhos de final de curso de engenharia, pesquisas de mestrado e publicações sobre o tema, com o foco concentrado em trocadores de calor utilizados no arrefecimento de hidrogeradores (Braga et al., 2011; Frota et al., 2014; Frota et al., 2014; Neves, 2013; Oliveira, 2015; Nunes, 2018; Lubicz, 2016; De Oliveira, 2016; Paixão, 2017; Barbosa et al., 2017; Oliveira et al., 2017, Rios et al., 2017 e Rios, 2017).

O Sistema de Injeção e Recuperação de Esferas Abrasivas (SIREA) proposto pelo grupo de pesquisa em trocadores de calor do Programa de PósGraduação em Metrologia (PósMQI) da PUC-Rio, foi desenvolvido no contexto do projeto de P\&D Light/Aneel Ref.: 07/2011 (Proposição de solução inovadora para 
o sistema de resfriamento dos hidrogeradores da Usina Fontes Nova), que resultou do desenvolvimento experimental de outro projeto de P\&D que o antecedeu (P\&D Light-Aneel Ref: 06/2007). Ambos esses projetos objetivaram sanar o problema de incrustação que ocorre nos trocadores de calor utilizados para arrefecimento das turbinas de geração da usina hidroelétrica Fontes Nova, de propriedade da Light, localizada no município de Piraí.

A alternativa de limpeza proposta objetivou evitar não só a interrupção da geração de energia, mas, também, a varetagem mecânica dos tubos do trocador de calor, tedioso processo (ilustrado na Figura 19), que pode colocar em risco a integridade mecânica da tubulação do trocador de calor.

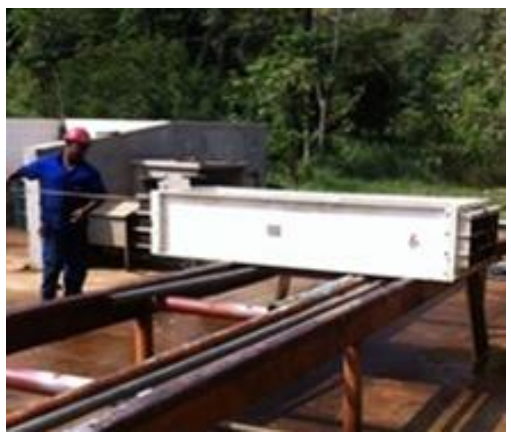

Figura 19 - Limpeza mecânica por varetagem Fonte: Rios, 2017

O processo tradicional de varetagem mecânica de cada um dos tubos internos do trocador de calor é um processo que requer a desmontagem do mesmo e demanda muito tempo para limpar os cerca de 70 tubos (frágeis e aletados), de aproximadamente $2 \mathrm{~m}$ de comprimento. Além de interromper a geração, a limpeza manual do trocador de calor demanda cerca de 3 a 4 dias, mobilizando pelo menos 5 profissionais da usina.

\subsection{1}

\section{Sistema manual de injeção e recuperação de esferas abrasivas}

O sistema manual de injeção e recuperação de esferas abrasivas, SIREA 1, foi o primeiro sistema a ser desenvolvido pelo Programa de Pós-Graduação em Metrologia, como resultado de um projeto de (P\&D Light-Aneel 07/2011). Construído em aço inoxidável, o sistema de limpeza era operado de forma totalmente manual e foi desenvolvido com o propósito de ser compacto, móvel, de baixo custo e eficaz na remoção de incrustação do trocador de calor. A Figura 20 mostra o SIREA 1 durante a fase de ensaios. 


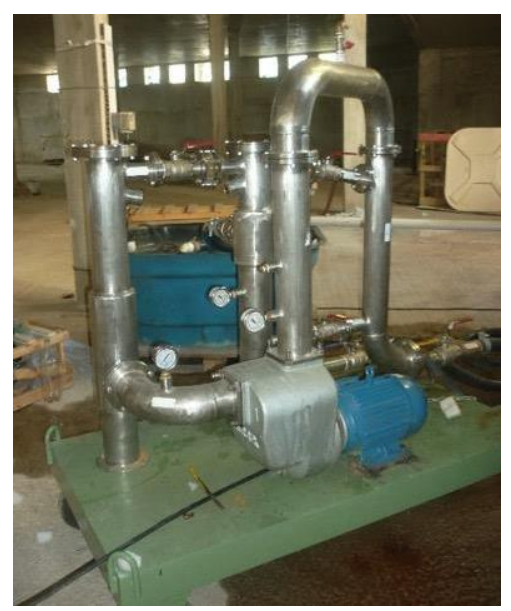

Figura 20 - Imagem do SIREA 1

Fonte: Oliveira, 2015

Os esquemáticos mostrados na Figura 21 explicam o funcionamento totalmente manual do sistema, que faz uso de esferas abrasivas, que são introduzidas pelo fluxo da água de resfriamento no interior dos tubos do trocador de calor, e então recuperadas, em cada ciclo de limpeza.
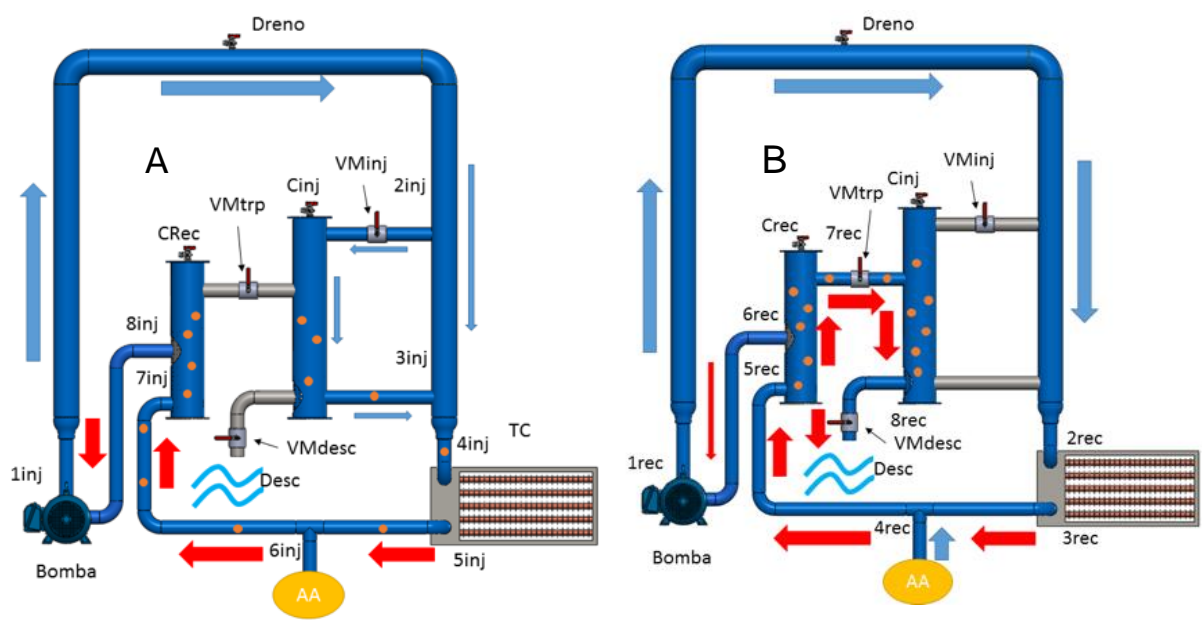

Figura 21 - Processo de injeção $(A)$ e recuperação $(B)$

As setas ilustram o fluxo da água de resfriamento (meio de transporte das esferas) no sistema. Neste esquemático, as esferas abrasivas utilizadas como artefatos de limpeza dos tubos do trocador de calor são representadas pelos símbolos na cor laranja. Os números e as abreviações destacam as partes integrantes do sistema. São eles:

- Bomba - Bomba geradora do fluxo do SIREA 1;

- Dreno - Dreno presente no sistema que auxilia no afogamento do equipamento (enchimento com água);

- $\quad V M_{i n j}$ - Válvula manual de injeção de esfera;

- $V M_{t p r}$ - Válvula manual de transposição de esfera;

- $V M_{\text {desc }}$ - Válvula manual de descarga do fluido de transporte da esfera;

- TC-Trocador de Calor;

- $A A$ - anel de alimentação de água de resfriamento; 
- $C_{i n j}$ - Câmara de injeção de esfera;

- $C_{\text {rec }}$ - Câmara de recuperação de esfera;

- Desc-Descarga de água;

- $1_{\text {inj }}$ - Bomba impulsora do fluxo principal de água do SIREA 1;

- $2_{i n j}$ - Fluxo parcial, desviado para a câmara de injeção;

- $3_{i n j}$ - Junção dos fluxos de transporte da esfera utilizada na limpeza dos tubos do TC;

- $4_{\text {inj }}$ - Esfera entra nos tubos internos do TC;

- $5_{i n j}$ - Esfera sai dos tubos do TC;

- $\sigma_{i n j}$ - Injeção da água do anel de alimentação;

- $7_{i n j}$ - Esfera entra na câmara de recuperação;

- $8_{\text {inj }}$ - Água oriunda da câmara de recuperação é utilizada para alimentar a Bomba;

- $1_{\text {rec }}$ - Bomba gera o fluxo principal de água;

- $2_{\text {rec }}$ - Fluxo de água entra no TC;

- $3_{\text {rec }}$ - Fluxo de água saí do TC;

- $4_{\text {rec }}$ - Injeção da água oriunda do anel de alimentação;

- $5_{\text {rec }}$ - Entrada do fluxo de água na câmara de recuperação;

- $\sigma_{\text {rec }}$ - Alimentação da Bomba com água da câmara de recuperação;

- $7_{\text {rec }}$ - Acionamento de parte do fluxo de água para permitir a transposição de esfera da câmara de recuperação para a de injeção;

- $8_{\text {rec }}$ - Descarga do fluxo de água.

Nota: Todas as saídas do sistema de limpeza para a descarga e o ponto denotado pela sigla $\boldsymbol{\sigma}_{\text {rec }}$ são protegidos com telas que não permitem que a esfera seja descartada em Desc e tampouco siga em direção ao rotor da bomba.

O início do ciclo de injeção ocorre segundo as configurações caracterizadas no Quadro 1, assegurando-se de que toda esfera a ser utilizada tenha sido previamente introduzida na câmara de injeção.

Quadro 1 - Posição das eletroválvulas válvulas do SIREA 1 para injeção de esferas

\begin{tabular}{c|c}
\hline Válvulas & Condição \\
$V M_{i n j}$ & Aberta \\
$V M_{t p r}$ & Fechada \\
$V M_{\text {desc }}$ & Fechada \\
\hline
\end{tabular}

O fluxo gerado pela bomba hidráulica passa por 2inj, entra na câmara de injeção e força a esfera a seguir para o trocador de calor para completar o ciclo de limpeza dos tubos. Após sair do trocador de calor, a esfera entra na câmara de recuperação, assim concluindo um ciclo de injeção.

Para o ciclo de recuperação faz-se necessário alterar as posições de funcionamento das válvulas conforme indicado no Quadro 2. 
Quadro 2 - Posição de comando das válvulas do SIREA 1 para recuperação de esferas

\begin{tabular}{c|c}
\hline Válvulas & Condição \\
$V M_{i n j}$ & Fechada \\
$V M_{t p r}$ & Aberta \\
$V M_{\text {desc }}$ & Aberta \\
\hline
\end{tabular}

O fluxo de água gerado pela bomba segue diretamente para o trocador de calor e, ao sair deste, entra na câmara de recuperação. A esfera é transferida para a câmara de injeção, e lá fica alojada aguardando a operacionalização do próximo ciclo de limpeza ser iniciado. O fluxo de água que transpõe a esfera é descarregado em Desc. Essa perda de água do sistema de limpeza no ciclo de recuperação é reposta por água oriunda do anel de alimentação, responsável pelo fornecimento da água de arrefecimento do trocador durante o seu funcionamento de rotina (i.e., quando o SIREA 1 não se encontra acoplado ao trocador).

Para acompanhamento da evolução do processo de limpeza do trocador de calor, foi implementado um sistema de medição (SisMed), que viabiliza a medição de temperatura e pressão dos fluidos de trabalho do trocador de calor. Esses medidores foram instalados nos tramos de entrada e de saída do trocador, utilizados para acoplamento do SIREA. Durante esses experimentos de avaliação da eficácia do dispositivo de limpeza SIREA 1, dois trocadores de calor em operação na usina hidrelétrica Fontes Nova foram instrumentados, um para acoplamento com o dispositivo de limpeza e outro para servir de comparação (denominado trocador de calor de referência). Os resultados dessas medições foram transmitidos para o Laboratório de acompanhamento (no caso do projeto de P\&D desenvolvido, a PUC-Rio), que analisou, de forma contínua, o impacto da limpeza no cálculo da efetividade e do fator de incrustação de ambos os trocadores instrumentados para monitoramento. Os fluxos de água nesses dois trocadores foram ajustados para assegurar que ambos operavam com a mesma vazão de água de resfriamento (cerca de $20 \mathrm{~m}^{3} / \mathrm{h}$ ). A instrumentação do sistema de limpeza foi realizada por meio de manômetros analógicos, enquanto as conexões com o trocador de calor, realizadas por tubos flexíveis equipados com engates do tipo rápido.

A bomba instalada no SIREA 1 foi selecionada para atender à condição de velocidade ótima de $2 \mathrm{~m} / \mathrm{s}$ (Bott, 1997) - análise feita pela curva da bomba, quando a esfera está circulando dentro dos tubos do trocador de calor. O SIREA 1 foi montado em cima de rodízios, que atribui mobilidade ao sistema de limpeza, possibilitando sua transferência para diferentes locais na área de trabalho. Quanto ao total de esferas a serem introduzidas no SIREA para realizar a limpeza, segue- 
se a recomendação de Müller-Steinhagen (200) de $10 \%$ a $30 \%$ do número de tubos do trocador de calor por passe.

O SIREA 1, cuja eficácia foi comprovada por meio de ensaios em laboratório, apresentou problemas durante o seu funcionamento em campo. Um vácuo era formado na parte superior da câmara de recuperação devido à sucção da bomba estar diretamente ligada à câmara de recuperação, assim dificultando a transposição das esferas no ciclo de recuperação. Essas esferas ficavam retidas na conexão da câmara de injeção de esferas com o tramo de sucção da bomba. A solução encontrada para eliminar o problema foi diminuir a rotação da bomba durante a recuperação de esferas e abrir o dreno de câmara de recuperação, assim eliminando o vácuo formado na parte superior da câmara de recuperação. Tal procedimento de operação permite que a água encha a câmara, assim eliminando os volumes preenchidos com ar e permitindo que a transposição de esferas entre as câmaras ocorra sem dificuldade.

A versão 1.0 do SIREA é totalmente manual (não possui nenhum sistema de automação), o que permitia falhas de operação por parte do operador (i.e., abertura ou fechamento indevido de válvulas durante as operações, colocando em risco a integridade do equipamento por indesejáveis golpes de aríete e interrupção do fluxo gerado pela bomba). A falta de constante renovação de água no SIREA 1 constitui outra desvantagem desta versão totalmente manual do equipamento, pois os detritos oriundos do procedimento de limpeza dos tubos do trocador de calor se acumulam na água após o procedimento de limpeza, aumentando a concentração de sujeira nos tramos do equipamento de limpeza. Isso acarretava o aquecimento da água que circula pelo SIREA 1, aumentando a pressão de vapor da água, podendo causar cavitação ${ }^{1}$ na bomba hidráulica.

Vantagens da versão 1.0 do SIREA:

- Uma única bomba proporcionava todo o funcionamento do sistema;

- Sistema sem componentes móveis (com exceção da bomba) o que evitava o desgaste dos demais componentes do sistema de limpeza;

- Simples funcionamento e eficaz na remoção de incrustações;

- Unidade móvel, factível de ser transferido para diferentes locais de operação;

- Tamanho reduzido, sem que isso afete a qualidade do processo de limpeza do TC;

- Tubos flexíveis e engates rápidos para acoplamento ao TC, o que simplifica a instalação do sistema como um todo;

\footnotetext{
${ }^{1}$ Cavitação denota o fenômeno de formação de bolhas de vapor e sua posterior implosão nas pás do rotor da bomba, que ocorre quando a pressão estática do fluido bombeado (mantido a uma determinada temperatura) desce até à pressão de vaporização (ou pressão de vapor), sofrendo, na sequência, um súbito aumento de pressão (KSB, 2015).
} 
- Poucas intervenções nas tubulações no local de instalação;

- Esferas não circulam por dentro da bomba, o que elimina o risco de danificá-las;

- Velocidade da esfera factível de ser ajustada para circular a $2 \mathrm{~m} / \mathrm{s}$ pelos tubos do TC (que é o valor recomendado por Bott, 1997);

- Permite controle do número de esferas injetadas;

- Factível de ser operado de forma integrada com o SisMed.

Desvantagens:

- Sistema totalmente manual, o que permitia erros de operação;

- Vulnerável a vácuo na câmara de recuperação, condição que requer manobras de operação para eliminar o problema;

- Possibilidade de cavitação, devido ao aumento de temperatura do fluido de trabalho;

- Mesmo o sistema sendo compacto, a sua elevada massa dificulta a sua mobilidade.

O projeto do SIREA 1 desencadeou outros dois sistemas de limpeza frutos do projeto P\&D Light/Aneel 5161/010/2016, objeto de contrato de P\&D celebrado entre a Light Energia S/A e a PUC-Rio (por meio de seu Programa de pósgraduação em Metrologia).

\subsection{2}

\section{Sistema automatizado de injeção e recuperação de esferas}

O Sistema de Injeção e Recuperação de Esferas Abrasivas Automatizado (versão 2.0 do SIREA, também conhecido como SIREA 2) foi desenvolvido no âmbito de um novo Projeto de P\&D (Light/Aneel 5161/010/2016), financiado pelo Programa regulado de P\&D Light/Aneel. Este novo projeto de P\&D teve como produto principal a automação e o aprimoramento do SIREA 1. O objetivo foi solucionar os problemas apresentados no SIREA 1. Embora totalmente automatizado, o SIREA 2 foi concebido para realizar os mesmos processos de limpeza originalmente colocados como desafio para o SIREA 1.

A Figura 22 ilustra uma imagem gerada pelo software Solidworks do protótipo construído da versão totalmente automatizada do SIREA 2 (Frota, 2018). 


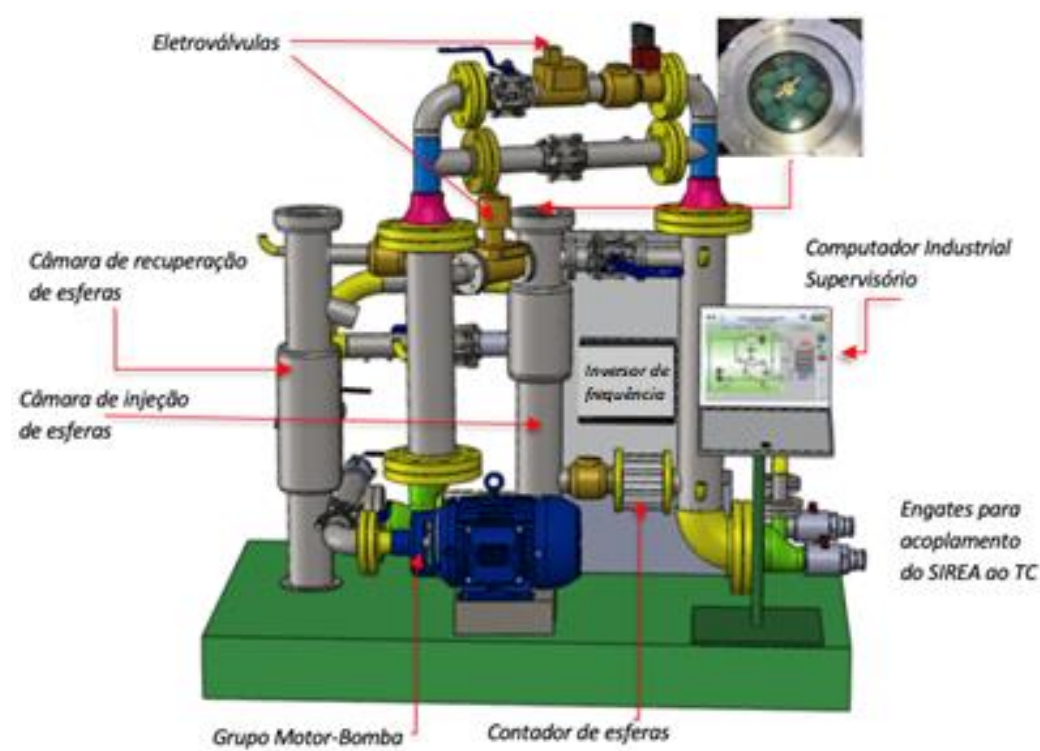

Figura 22. Projeto construtivo do Protótipo da versão automatizada do SIREA

Fonte: Frota, 2018

A Figura 23 mostra o SIREA 2 em operação na usina de Fontes Nova, onde o sistema atualmente encontra-se instalado e disponível para entrar em operação sob a decisão da equipe de operação da usina.

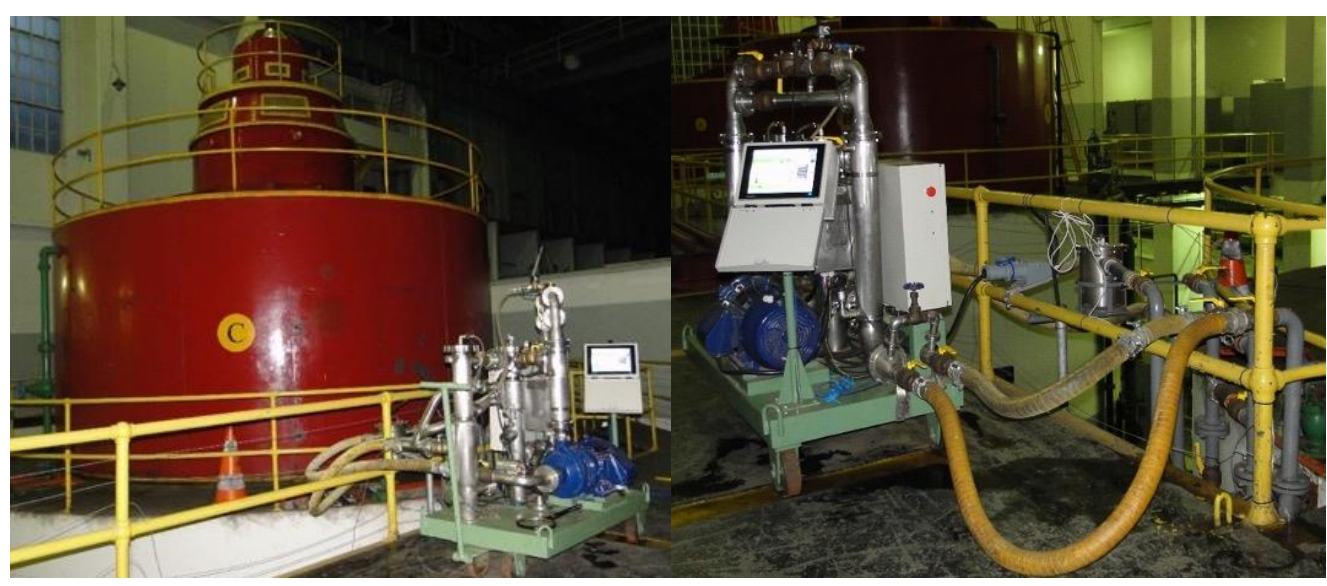

Figura 23 - SIREA 2 acoplado ao sistema de arrefecimento do hidrogerador Fonte: Frota e colaboradores (2016) (usina Fontes Nova)

Os esquemáticos mostrados na Figura 24 explicam o funcionamento do sistema durante os processos de injeção e recuperação de esfera, respectivamente. 

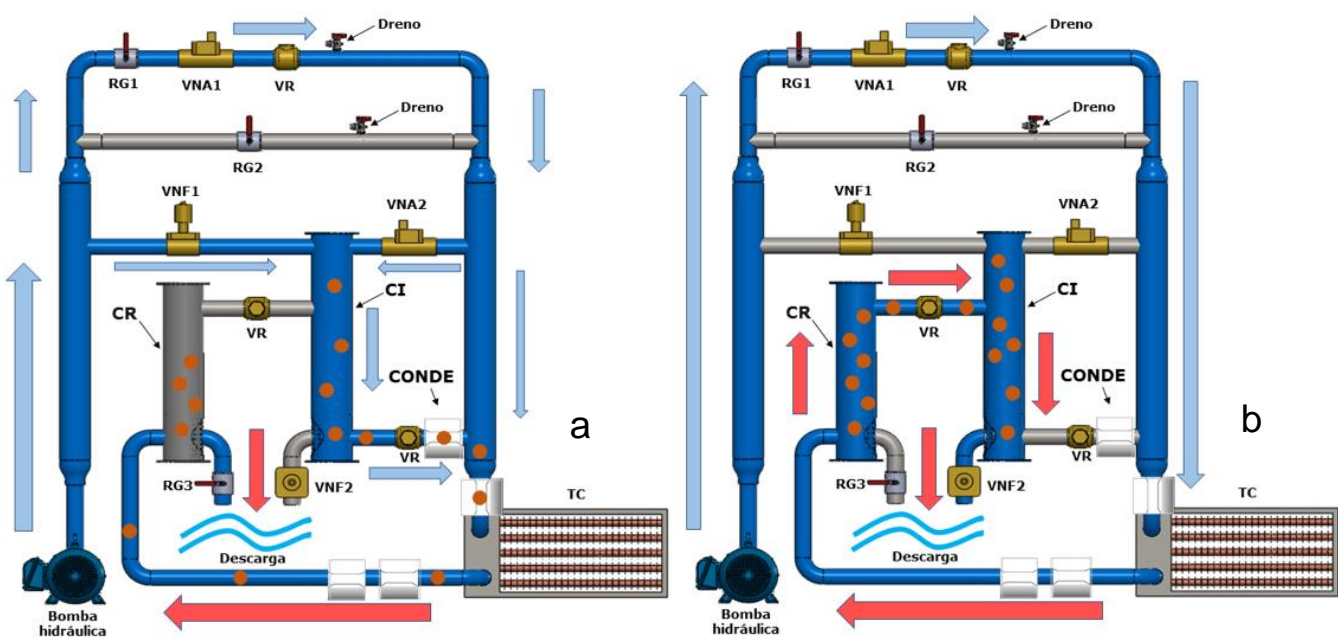

Figura 24 - Processo de injeção (a) e recuperação (b) de esfera

As setas indicam o fluxo da água de resfriamento (meios de transporte da esfera abrasiva) no interior dos tramos do sistema. Neste esquemático, a esfera abrasiva utilizada como artefato de limpeza dos tubos do trocador de calor é representada pelos símbolos na cor laranja. As abreviações, a seguir decodificadas, destacam partes integrantes do sistema. São elas:

- Bomba hidráulica - Bomba geradora do fluxo de água de resfriamento no sistema;

- Dreno - Drenos de ar instalados no sistema;

- $R G$ - Registro manual para interrupção de fluxo;

- VNA - Válvula solenoide, do tipo Normalmente Aberta;

- VNF - Válvula solenoide, do tipo Normalmente Fechada;

- $\quad V R$ - Válvula de retenção, para limitar o fluxo em um único sentido;

- TC - Trocador de Calor;

- $\mathrm{Cl}$ - Câmara de injeção de esfera;

- CR - Câmara de recuperação de esfera;

Nota: Todas as saídas do sistema de limpeza para a descarga são protegidas com telas (peneiras) que não permitem a passagem de esfera para a Descarga.

O início do ciclo de injeção ocorre segundo as configurações programadas na Quadro 3, assegurando-se de que toda esfera a ser utilizada tenha sido previamente introduzida na câmara de injeção.

Quadro 3 - Posição das válvulas para injeção de esfera do SIREA 2

\begin{tabular}{c|c}
\hline Válvula & Condição \\
RG1 & Aberta \\
VNA1 & Aberta \\
VNA2 & Aberta \\
VNF1 & Aberta \\
$R G 2$ & Fechada \\
RG3 & Parcialmente aberta \\
VNF2 & Fechada \\
\hline
\end{tabular}

O fluxo gerado pela bomba hidráulica do sistema de limpeza passa pela câmara de injeção e carrega as esferas para o trocador de calor para realizar a 
limpeza do interior de seus tubos. Ao saírem do trocador, as esferas são direcionadas para a câmara de recuperação e o ciclo de injeção é encerrado.

Para o ciclo de recuperação faz-se necessário alterar a posição das válvulas e colocá-las conforme as configurações definidas na Quadro 4.

\begin{tabular}{c|c} 
Quadro 4 - Posição das válvulas para recuperação de esfera do SIREA \\
\hline Válvula & Condição \\
RG1 & Aberta \\
VNA1 & Fechada \\
VNA2 & Fechada \\
VNF1 & Fechada \\
RG2 & Fechada \\
RG3 & Parcialmente aberta \\
VNF2 & Aberta \\
\hline
\end{tabular}

O fluxo de água de resfriamento gerado pela bomba segue direto para o trocador de calor circulando pelo seu interior e chegando à câmara de recuperação. Com VNF2 na posição aberta, a transposição das esferas entre a câmara de recuperação e de injeção ocorre. Nos dois ciclos, o registro manual RG3 permanece na posição parcialmente aberta gerando, para o caso da recuperação, uma perda de carga suficiente que obriga o fluxo a passar por $V R e$ ser descarregado em VNF2.

A mudança do ponto de alimentação de água da bomba hidráulica, não mais feita na câmara de recuperação (tal qual ocorria no SIREA 1), mas sim em um ponto fora do sistema, o que permitiu eliminar o problema da formação de vácuo na parte superior da câmara de recuperação. A introdução de válvulas solenoides e a integração delas com o sistema de automação (que passou a comandar os processos de abertura e fechamento das válvulas solenoides) possibilitaram a automação de funcionamento do SIREA 2. Os registros manuais, em condições normais de funcionamento do sistema de limpeza, estão sempre na posição de registro aberto, com exceção de $R G 2$, que sempre permanece na posição de registro fechado. Esses registros só são operados em situação de defeito de alguma das válvulas solenoides, permitindo que o SIREA 2 seja operado no seu modo manual.

O SIREA 2 foi instrumentado com medidores de pressão, que permitem medir a grandeza física de interesse em pontos sensíveis do sistema (i.e., câmaras de injeção e recuperação e nos tramos de entrada e de saída do sistema de limpeza que se conectam com o trocador de calor). O SISMED segue em funcionamento transmitindo (remotamente) dados de temperatura e pressão dos fluidos de trabalho dos trocadores monitorados pelo projeto de pesquisa. $O$ 
impacto da limpeza no valor da efetividade e do fator de incrustação do trocador de calor é continuamente avaliado.

Um dispositivo eletrônico que atua como contador de esferas (CONDE) (Barbosa et al., 2017) (Nunes, 2018) é utilizado para verificar se a quantidade de esferas que foram introduzidas nos tubos do trocador de calor é a mesma que retorna à câmara de recuperação após cada ciclo de limpeza, possibilitando saber se algum dos artefatos de limpeza ficou ou não retido. O diâmetro interno do CONDE é projetado para permitir que apenas uma esfera passe por vez, o que possibilita a correta contagem dos artefatos de limpeza em circulação pelo trocador de calor. A Figura 25 mostra a placa eletrônica utilizada e a Figura 26 mostra o dispositivo CONDE utilizado na versão 2.0 do SIREA.

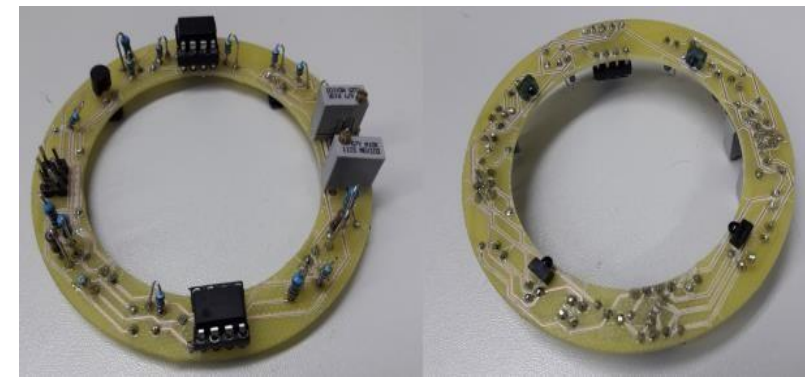

Figura 25 - placa utilizada no CONDE Fonte: Barbosa et al., 2017

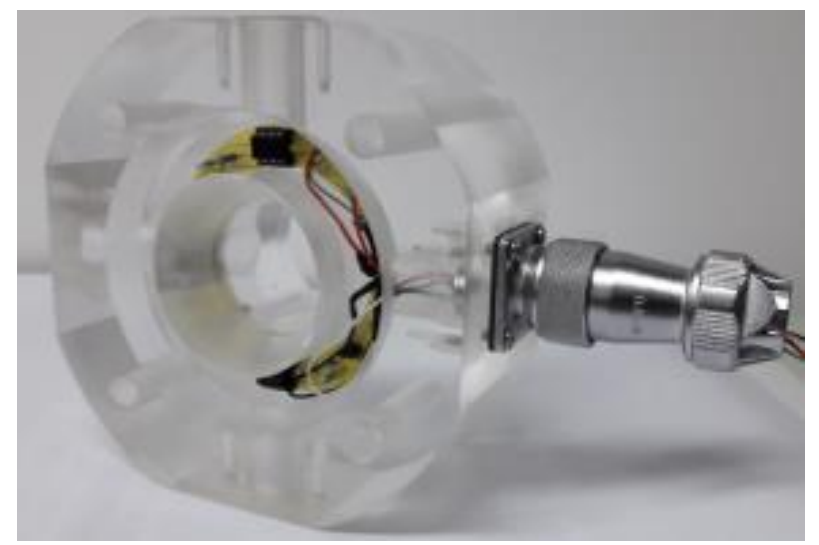

Figura 26 - CONDE simples totalmente montado Fonte: Barbosa et al., 2017

\section{Vantagens do SIREA 2:}

- Sistema totalmente automatizado, portanto, totalmente autônomo;

- Equipado com dispositivo para contagem de esferas (CONDE) e que também estima os valores de suas velocidades de circulação;

- Equipado com interface homem-máquina (IHM), que funciona como supervisório para controle da automação e medições de temperatura, pressão e velocidade da esfera;

- Equipado com uma única bomba, que proporciona todo o funcionamento do sistema; 
- Sistema sem componentes móveis (com exceção da bomba), o que evita o desgaste das demais peças do sistema de limpeza;

- Sistema com funcionamento simples e eficaz na remoção de incrustação;

- Mobilidade, podendo ser transportado para diferentes locais e acoplado a diferentes trocadores;

- Acoplado ao TC por meio de tubos flexíveis e engates rápidos;

- Necessárias poucas intervenções nas tubulações no local de instalação;

- Esfera circula externamente à bomba, portanto evitando que esta seja exposta ao rotor da bomba.

- Possibilidade de controlar a velocidade de circulação da esfera em torno do valor de $2 \mathrm{~m} / \mathrm{s}$, que é o valor recomendado para assegurar eficácia do processo de limpeza;

- Possibilidade de controle do número de esfera injetada.

Desvantagens:

- Embora totalmente automatizado e móvel, o sistema é mais pesado que a sua versão não automatizada;

- Sistema extremamente compacto, o que dificulta a substituição de partes do sistema.

\subsection{3}

\section{Versão compacta do sistema inovador de limpeza (SIREA 3)}

O sistema inovador de limpeza de trocador de calor, denominado SIREA 3, utiliza todo o conhecimento desenvolvido e acumulado com a experiência de desenvolvimento e ensaios dos projetos SIREA 1 e SIREA 2. A geometria do novo projeto favorece a hidrodinâmica de operação do sistema de limpeza, enquanto a sua automação assegura eficiência à operação do dispositivo.

O projeto construtivo foi desenvolvido com o auxílio do programa de modelagem 3D Solidworks, que se constitui em importante ferramenta de projeto e análise de tensões, montagem e posicionamento dos elementos que compõem o sistema sendo projetado. O software Solidworks permitiu prever diversos problemas de dimensões inapropriadas de componentes, bem como proporcionar soluções antes mesmo da montagem do protótipo, o que gerou ganho de tempo, economia de recursos financeiros para a elaboração e montagem do novo sistema de limpeza e melhoria no design do produto final. A Figura 27 mostra o desenho 3D desenvolvido, totalmente integrado, e o protótipo construído do sistema alternativo de limpeza. 


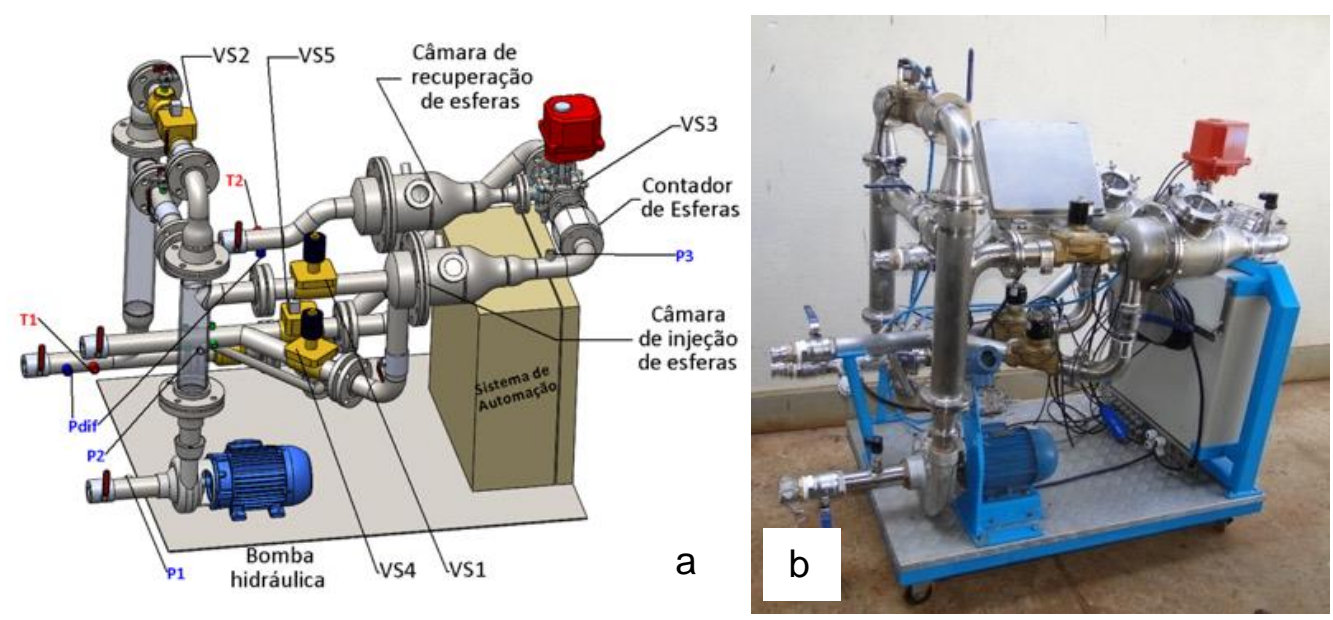

Figura 27 - Projeto construtivo (a) e protótipo (b) do SIREA 3

Fonte: Rios, 2017

\subsubsection{1}

\section{Identificação e funcionamento da alternativa proposta}

Os esquemáticos da Figuras 28 explicam, respectivamente, o funcionamento dos processos de injeção (Fig. 28a) e recuperação (Fig. 28b) das esferas abrasivas inseridas no trocador de calor.

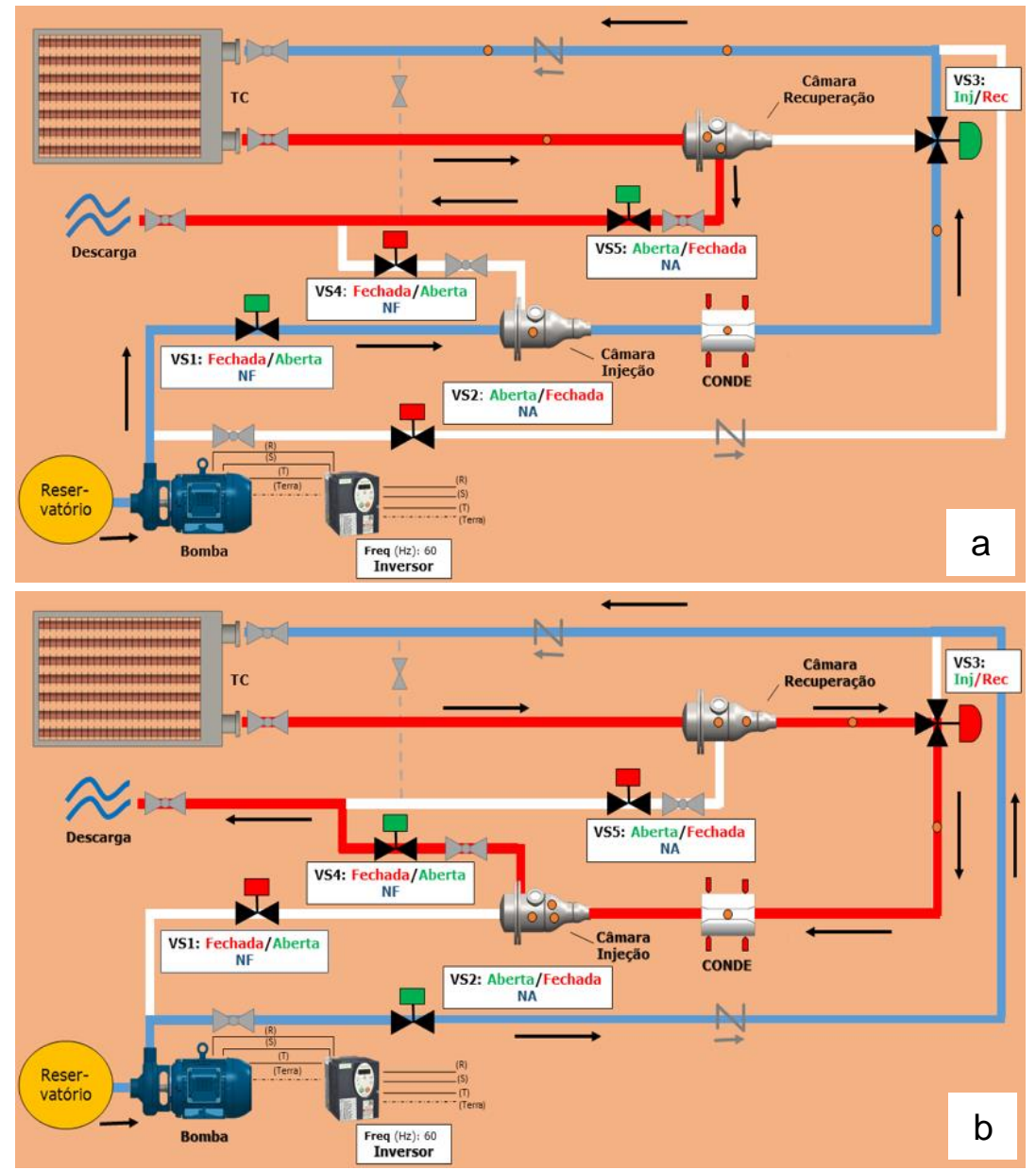

Figura 28 - Fluxo associado ao processo de injeção (a) e recuperação (b) de esfera 
As setas representam o fluxo da água do sistema. Nesses esquemáticos, as esferas abrasivas utilizadas como artefatos de limpeza dos tubos do trocador de calor são representadas pelos objetos esféricos na cor laranja. As abreviações, a seguir decodificadas, destacam partes integrantes do sistema. São elas:

- Bomba - Bomba hidráulica geradora do fluxo de água do sistema;

- Inversor - Inversor de frequência utilizado no sistema;

- TC - Trocador de Calor;

- CONDE - Contador de esferas duplo;

- Reservatório - Reservatório de água que alimenta a bomba hidráulica;

- VS1 - Válvula Solenoide de injeção;

- VS2-Válvula Solenoide de by pass;

- VS3 - Válvulas de 3 vias;

- VS4-Válvula Solenoide de transposição;

- VS5- Válvula Solenoide de descarga;

- $\quad N A$ - Válvula solenoide normalmente aberta;

- NF - Válvula solenoide normalmente fechada;

Nota: Todas as saídas das câmaras de injeção e recuperação para a descarga são protegidas com uma tela que não permite a passagem de esfera.

O sistema alternativo de limpeza é equipado com uma interface homemmáquina (IHM), que funciona como supervisório para indicar: (i) a natureza da operação que está ocorrendo; (ii) o total de ciclos de limpeza já realizados; (iii) os resultados de medições de pressão e temperatura da água de resfriamento que circula pelo equipamento; (iv) o total de esferas circulantes no trocador e (v) a velocidade de cada esfera que cruza o feixe infravermelho emitido pelo CONDE, assim permitindo a contagem das esferas e a sua velocidade. A Figura 29 mostra a tela do supervisório do sistema de automação do equipamento de limpeza.

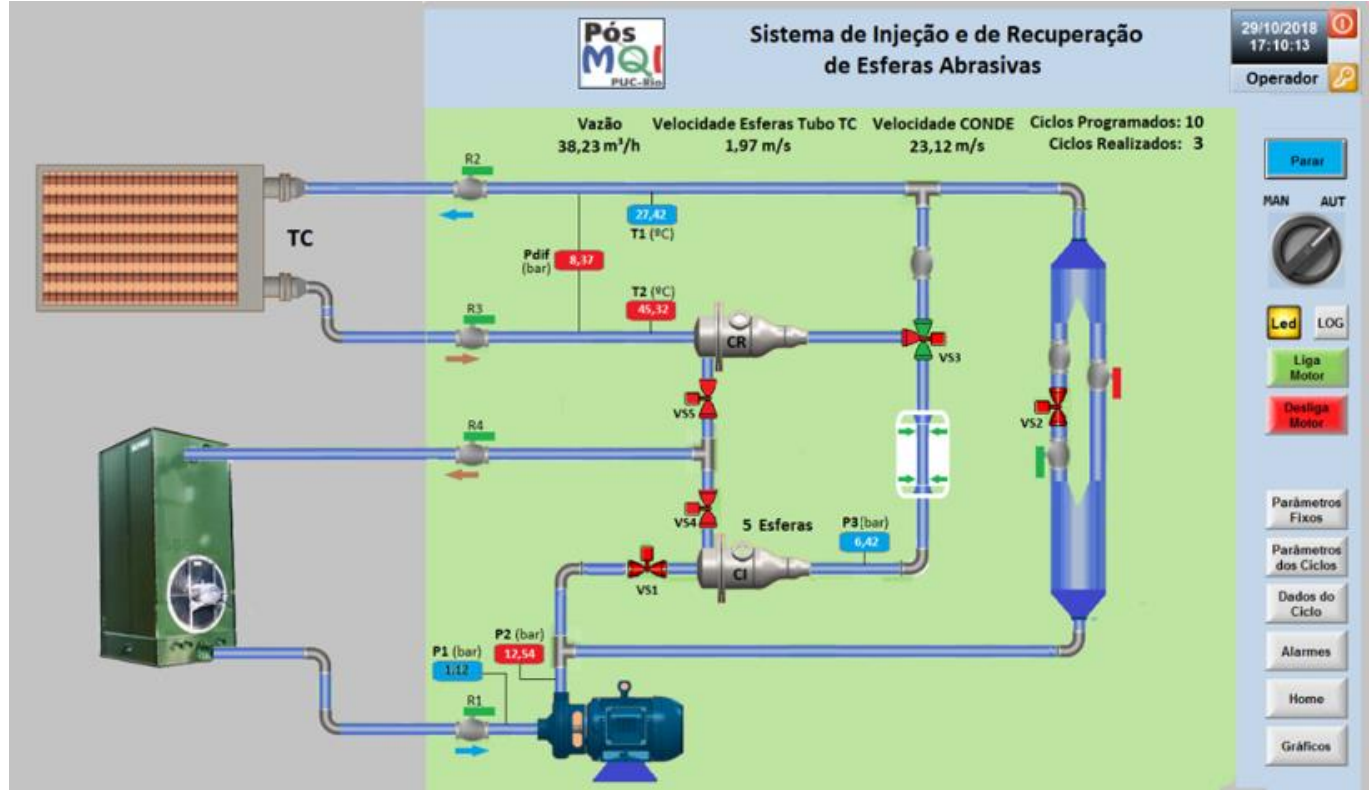

Figura 29 - Tela do supervisório 
O início do ciclo de injeção ocorre segundo as configurações previamente programadas na Quadro 5. Consegue-se, assim, saber se, de fato, toda esfera efetivamente introduzida na Câmara de Injeção (no caso do primeiro ciclo de funcionamento) retornou à câmara de injeção, após sua passagem pelos tubos do trocador de calor.

Quadro 5 - Posição das válvulas para injeção de esferas

\begin{tabular}{c|c}
\hline Válvulas & Condição \\
VS1 & Aberta \\
VS2 & Fechada \\
VS3 & Injeção \\
VS4 & Fechada \\
VS5 & Aberta \\
\hline
\end{tabular}

O fluxo de água gerado pela bomba hidráulica (força motriz do SIREA 3) entra na Câmara de Injeção para impulsionar as esferas que serão forçadas no trocador de calor, passando antes pelo CONDE, que totaliza o número de esferas injetadas e calcula a velocidade média de cada esfera que cruza o feixe optoeletrônico. A esfera passa pela válvula de 3 vias e segue para o trocador de calor para realizar a limpeza dos tubos. Ao sair do trocador, é direcionada para a câmara de recuperação onde o próprio fluxo lança a esfera contra uma peneira, que não permite que ela escape para a descarga. Esse choque faz com que a esfera solte as incrustações removidas dos tubos do trocador de calor que, porventura, tenham ficado presas na esfera. Após esse processo, encerra-se um ciclo de injeção.

Para o ciclo de recuperação é necessário alterar a posição das eletroválvulas e reposicioná-las em conformidade às configurações da Quadro 6.

Quadro 6 - Posição das válvulas para recuperação de esferas

\begin{tabular}{c|c}
\hline Válvulas & Condição \\
VS1 & Fechada \\
VS2 & Aberta \\
VS3 & Recuperação \\
VS4 & Aberta \\
VS5 & Fechada \\
\hline
\end{tabular}

O fluxo de água gerado pela bomba segue direto para o trocador de calor, circula pelo interior dos tubos e chega na Câmara de Recuperação. Com VS3 em modo de recuperação e VS4 aberta e VS5 fechada, ocorre a transposição da esfera entre a câmara de recuperação e a câmara de Injeção. Nesse percurso, entre essas duas câmaras, a esfera passa pelo CONDE, que novamente conta o total de esferas (desta vez no seu retorno, após passar pelo trocador), permitindo, 
assim, verificar se a mesma quantidade de esferas inseridas foi recuperada. Esferas acidentalmente retidas dentro de um dos tubos do trocador de calor são usualmente resgatadas por um processo independente de retro lavagem (inversão do fluxo de água no trocador de calor).

\subsubsection{2}

\section{Características do sistema alternativo de limpeza}

O SIREA 3 é mais compacto que suas versões 1.0 e 2.0 discutidos nas seções anteriores. A utilização de uma válvula de 3 vias motorizada constituiu-se na essência da redução de porte do equipamento, já que substancialmente reduziu o número de eletroválvulas e de tramos do equipamento. A válvula de 3 vias é fundamental, pois possibilita que o fluxo de água passe, por um mesmo tramo, em dois sentidos, requerendo um único CONDE (que conta as esferas no processo de injeção e de recuperação).

O sistema de limpeza alternativo é totalmente automatizado e autônomo, reduzindo a interferência humana na sua operação. Esse sistema de limpeza opera com um CONDE duplo, equipado com duas placas de circuito optoeletrônico, cada uma com dois pares (redundância) de sensores do tipo emissor-receptor montadas em um único bloco de acrílico. A Figura 30 mostra o CONDE duplo instalado no sistema de limpeza.

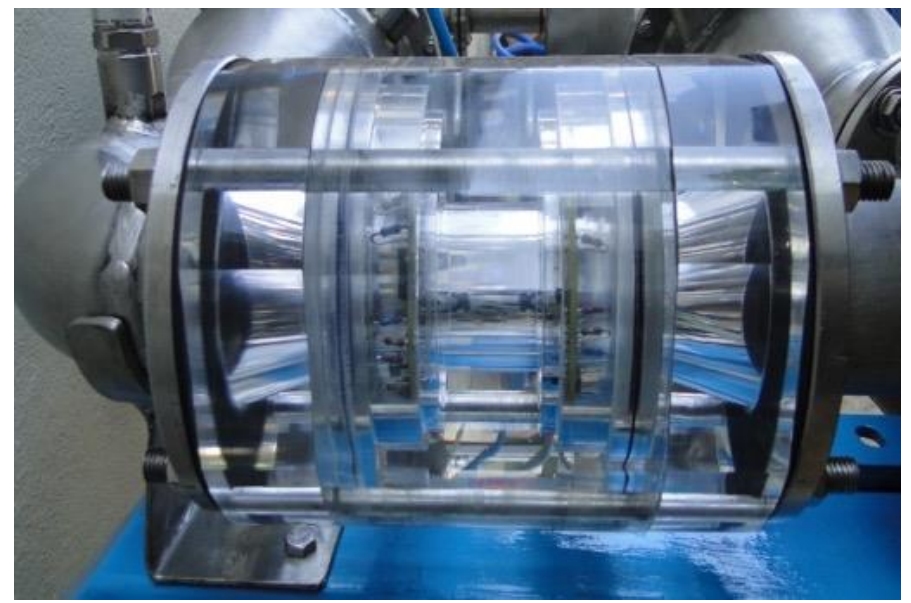

Figura 30 - CONDE duplo instalado no SIREA 3 


\section{3}

\section{Validação do dispositivo de limpeza e estudo de seus ciclos}

Visando validar o funcionamento da alternativa tecnológica concebida e construída (Frota et al., 2018; Frota et al., 2019) para introduzir e remover esferas abrasivas (artefatos de limpeza) no interior dos tubos do trocador de calor com o propósito de desobstruí-los, três ensaios complementares foram desenvolvidos em ambiente laboratorial: (i) ensaio de estanqueidade; (ii) ensaio de funcionalidade e (iii) calibração da bomba hidráulica, para habilitá-la como medidor de vazão da água que circula pelos tubos do trocador (e, por conseguinte, da velocidade do artefato de limpeza transportada pela água bombeada).

A Figura 31 mostra a tela do supervisório da Interface Homem-Máquina (IHM) do sistema de automação implementado no equipamento desenvolvido e discutido no capítulo anterior.

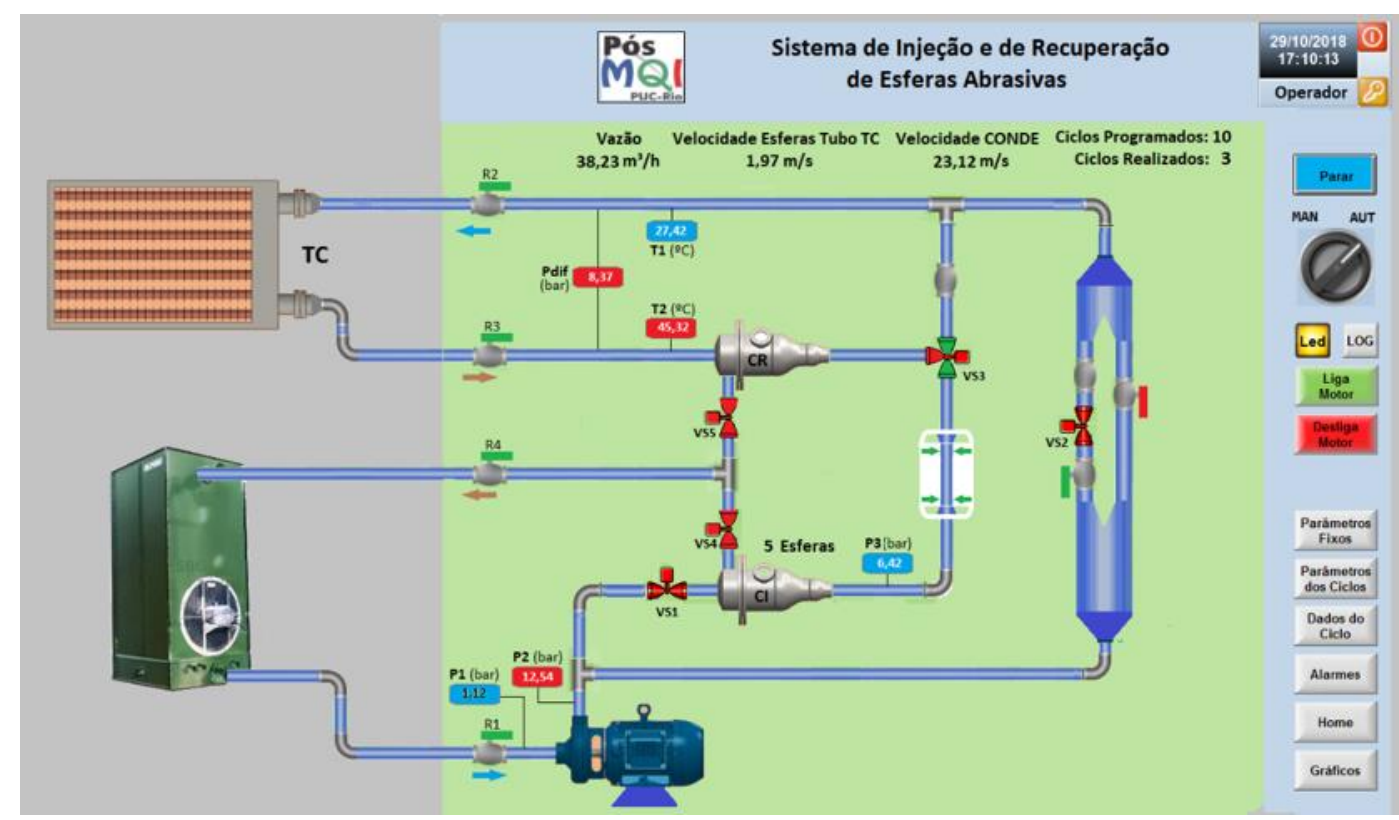

Figura 31 - Tela do supervisório do sistema de automação

De forma esquemática, a figura acima ilustra o sistema de limpeza alternativo construído, com seus diferentes circuitos hidráulicos (de injeção de esferas; de recuperação de esferas, após circularem pelos tubos do trocador e de transposição das esferas da câmara de recuperação para a câmara de injeção, preparando o sistema para que possa realizar um novo ciclo de limpeza). Uma bomba hidráulica garante o fluxo do fluido de trabalho (água de resfriamento) que transporta as esferas para o interior dos tubos do trocador (dispositivo de limpeza somente aplicável a trocador de calor trocador de calor do tipo tubular). Transdutores digitais de pressão (fabricante WIKA, 0,01 bar de resolução, fundo 
de escala: 10 bar) encontram-se instalados em posições críticas do dispositivo de limpeza, assim permitindo a medição do diferencial de pressão $\left(P_{2}-P_{1}\right)$ imposto pela bomba, bem como a pressão $P_{3}$, na saída da câmara de injeção. Termorresistências "Pt100" (resistência de Platina) permitem medições de temperatura na entrada e na saída do TC submetido ao processo de limpeza. $\mathrm{Na}$ Figura 31 ilustram-se as eletroválvulas identificadas com os símbolos $V S_{1}$ a $V S_{5}$, conforme descrito a seguir:

- $\quad V S_{1}$ (válvula solenoide, normalmente fechada);

- $\quad V S_{2}$ (válvula solenoide, normalmente aberta);

- $V S_{3}$ (válvula motorizada de 3 vias);

- $V S_{4}$ (válvula solenoide, normalmente fechada);

- $V S_{5}$ (válvula solenoide, normalmente aberta).

Essa figura (tela do supervisório) também mostra os botões do tipo touch screen de controle do sistema interativo de automação.

\section{1}

\section{Ensaio de estanqueidade}

Com o propósito de avaliar a integridade dos diferentes tramos hidráulicos do equipamento de limpeza, este foi submetido a um ensaio de estanqueidade.

A Figura 32 mostra o aparato experimental utilizado no ensaio (A). Conforme mostrado, uma caixa d'água, com capacidade de 500 litros, foi instalada em um andaime, a 2,30 m de altura da seção de entrada da bomba (B), assim afogando o sistema para (i) manter os tramos hidráulicos do equipamento sob pressão positiva ( 0,23 bar) e (ii) impedir a entrada de ar, que compromete o funcionamento do contador de esferas, já que pacotes de bolhas geram falsos positivos no processo de contagem das esferas que circulam pelo sistema.

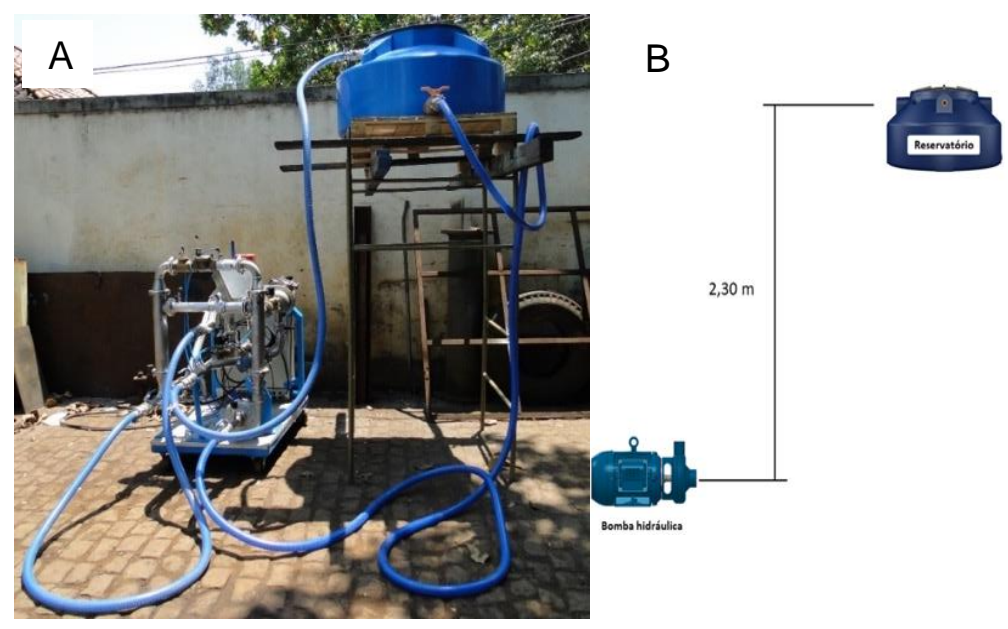

Figura 32 - Acoplamento do sistema de limpeza ao reservatório de água 
A Figura 32 ilustra uma foto da montagem experimental utilizada no ensaio de estanqueidade realizado no equipamento de limpeza (SIREA 3). A caixa de água utilizada como fonte de alimentação da bomba hidráulica garantiu uma pressão positiva na entrada da bomba, enquanto os pontos de acoplamento do equipamento ao trocador de calor (ausente no ensaio) foram "curto-circuitados".

O ensaio de estanqueidade compreendeu duas etapas: (i) teste hidrostático, ou seja, tramos hidráulicos submetidos à pressão imposta pela coluna d'água (0,23 bar) e (ii) ensaio dinâmico, quando a pressão da água nos tramos do equipamento injetor/receptor de esferas abrasivas foi aumentada de um fator de 10 (i.e.: passou de 0,23 bar a 2,3 bar) pela ação da bomba hidráulica (fabricante Dancor, modelo 415 TJM, acoplada a motor de 4 cv de potência), responsável pelo fluxo de água de resfriamento do trocador (meio de transporte das esferas).

Exclusivamente para o teste em pauta, um manômetro analógico (fabricante WIKA, com 0,2 bar de resolução), mostrado na Figura 33, foi instalado no tubo de recalque da bomba ( $\mathrm{P}_{2}$, na Figura 31$)$, permitindo, de maneira prática (sem a necessidade de interfaces analógico/digital), monitorar o nível de pressão imposto pela bomba hidráulica durante o ensaio dinâmico.

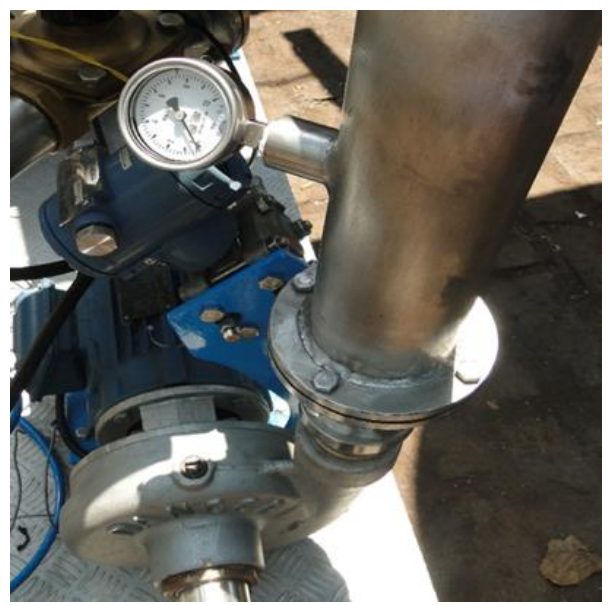

Figura 33 - Instalação para monitoramento da pressão de recalque

Durante o ensaio dinâmico, os tramos hidráulicos foram mantidos à pressão máxima de 2,3 bar, impondo uma vazão de $50 \mathrm{~m}^{3} / \mathrm{h}$, assim simulando o fluxo de água de resfriamento (meio de transporte de esferas abrasivas), com o rotor da bomba operando em sua rotação máxima (inversor de frequência a $60 \mathrm{~Hz}$ ).

Após corrigir pequenos vazamentos que sempre se fazem presentes nas juntas de vedação dos flanges de acoplamento dos tramos, os ensaios de estanqueidade realizados com o sistema submetido à pressão hidrostática e dinâmica qualificaram o equipamento para ser submetido ao ensaio de 
funcionalidade; i.e., verificar o trânsito das esferas entre as câmaras de injeção e recuperação e ao longo do tubo flexível que simulou o circuito hidráulico do TC.

\section{2}

\section{Ensaio de funcionalidade}

O ensaio de funcionalidade permitiu observar a movimentação de esferas em três circuitos hidráulicos distintos. A Figura 34 mostra a Câmara de Injeção de Esferas (Cl) alimentada com 9 esferas (8 delas são visualizadas na Figura 34).

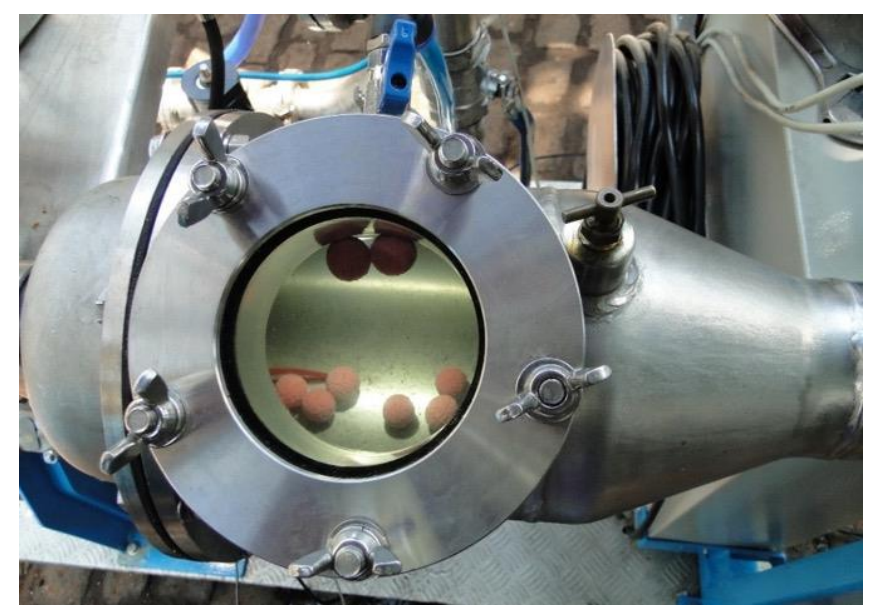

Figura 34 - Câmara de injeção alimentada com esferas abrasivas

A operação de injeção de esferas é iniciada com a entrada em operação da bomba hidráulica, mantendo-se as eletroválvulas em posições específicas. As subseções, a seguir, detalham cada um dos três ensaios de funcionalidade realizados. Cada ensaio será caracterizado pelas posições de suas eletroválvulas, pelos valores da pressão medida na descarga da bomba (pressão de recalque) e vazão de água, estimada pela curva da bomba, a partir da leitura da pressão no recalque (i.e.: pela curva característica de funcionamento da bomba hidráulica).

Os dados da Tabela 7 caracterizam o ensaio de injeção de esferas; ou seja, transporte das esferas da câmara de injeção para o interior dos tubos do trocador de calor (simulado por uma mangueira flexível acoplada entre os tramos extremos do dispositivo de limpeza). Ao término deste processo, as esferas são recuperadas, permanecendo na Câmara de Recuperação (CR), até que o operador acione o sistema de automação para direcionar as esferas de volta à câmara de injeção, assim preparando o sistema para que um novo ciclo de limpeza possa ser iniciado.

O valor da vazão de água nos circuitos hidráulicos do dispositivo de limpeza apresentado na Tabela 1 foi estimado pela curva de calibração da bomba hidráulica, realizada na bancada do fabricante. 
Tabela 1 - Configuração de válvulas, P2 e vazão durante injeção

\begin{tabular}{c|c|c|c}
\hline Válvulas & Condição & $\begin{array}{c}\text { Pressão no } \\
\text { recalque, } \mathrm{P}_{2}\end{array}$ & Vazão \\
VS1 & Aberta & & \\
VS2 & Fechada & $2,3 \mathrm{bar}$ & \multirow{2}{*}{$50 \mathrm{~m}^{3} / \mathrm{h}$} \\
VS3 & Injeção & $(23,5 \mathrm{mca})$ & \\
VS4 & Fechada & & \\
VS5 & Aberta & & \\
\hline
\end{tabular}

Os dados da Tabela 2 caracterizam o ensaio de recuperação das esferas injetadas após o término do processo de injeção. Esses dois processos integram o que se denomina um ciclo de limpeza.

Similarmente, a vazão de água no circuito de recuperação foi estimada pela curva de calibração da bomba hidráulica.

Tabela 2 - Configuração de válvulas, P2 e vazão durante recuperação

\begin{tabular}{c|c|c|c}
\hline Válvulas & Condição & $\begin{array}{c}\text { Pressão no } \\
\text { recalque, } \mathrm{P}_{2}\end{array}$ & Vazão \\
VS1 & Fechada & & \\
VS2 & Aberta & $2,0 \mathrm{bar}$ & \multirow{2}{*}{$53 \mathrm{~m}^{3} / \mathrm{h}$} \\
VS3 & Recuperação & $(20,4 \mathrm{mca})$ & \\
VS4 & Aberta & & \\
VS5 & Fechada & & \\
\hline
\end{tabular}

Os dados da Tabela 9 caracterizam o processo de autolavagem das esferas utilizadas após um ciclo completo de limpeza, processo esse viabilizado circulando-se esferas entre as duas câmaras (sem passar pelo trocador) quantas vezes fossem necessárias para assegurar a limpeza das esferas, o que é feito por inspeção visual (do estado das esferas) pelo visor instalado em cada uma dessas câmaras. Neste processo de limpeza as esferas impregnadas de incrustação são expostas a um fluxo de água forçado pela bomba (a sujeira se desprende das esferas ao circularem e se chocarem contra a peneira-filtro, que permite a passagem da sujeira sem deixar que as esferas se percam no circuito de descarga da água. Esse processo de limpeza de esfera ocorre, a critério do operador do dispositivo de limpeza, após o término de um ou mais ciclos de limpeza.

Os dados da Tabela 3 caracterizam as posições das eletroválvulas durante o ensaio de lavagem das esferas, realizado com a bomba operando na vazão de $50 \mathrm{~m}^{3} / \mathrm{h}$ e a uma pressão de recalque de 2,5 bar. 
Tabela 3 - Configuração de válvulas, P2 e vazão durante o ensaio de lavagem de esfera

\begin{tabular}{c|c|c|c}
\hline Válvulas & Condição & $\begin{array}{c}\text { Pressão no } \\
\text { recalque, } \mathrm{P}_{2}\end{array}$ & Vazão \\
VS1 & Fechada & & \\
VS2 & Aberta & $2,5 \mathrm{bar}$ & \multirow{2}{*}{$50 \mathrm{~m}^{3} / \mathrm{h}$} \\
VS3 & Recuperação & $(25,5 \mathrm{mca})$ & \\
VS4 & Fechada & & \\
VS5 & Aberta & & \\
\hline
\end{tabular}

\section{3}

\section{Qualificação metrológica do dispositivo de limpeza}

O dispositivo de limpeza foi qualificado (i) quanto à sua eficácia de operação (capacidade de injetar, movimentar e recuperar as esferas abrasivas ao longo dos tubos do TC e sincronismo das eletroválvulas que comandam os fluxos segundo os diferentes tramos do equipamento) e (ii) quanto às alternativas de pressurização do sistema.

\subsection{1}

\section{Visualização da eficácia de operação}

Para verificar a eficácia de operação do dispositivo de limpeza, que inclui conseguir impulsionar as esferas pelos tubos do trocador e controlar os servoprocessos de abertura e fechamento das eletroválvulas, o dispositivo de limpeza foi acoplado, em ambiente laboratorial, a um trocador de calor de acrílico especificamente construído para atender este propósito, que permitiu visualizar o escoamento do fluido de trabalho do TC que transporta as esferas pelos tubos do trocador. A visualização do escoamento foi considerada extremamente útil como ferramenta de qualificação do dispositivo de limpeza, permitindo ajustar a pressão nos tubos, os tempos de sincronização das eletroválvulas e a otimização dos tempos de duração dos ciclos de limpeza. A Figura 35 ilustra o trocador de calor de acrílico construído, acoplado por mangueiras ao dispositivo de limpeza. 


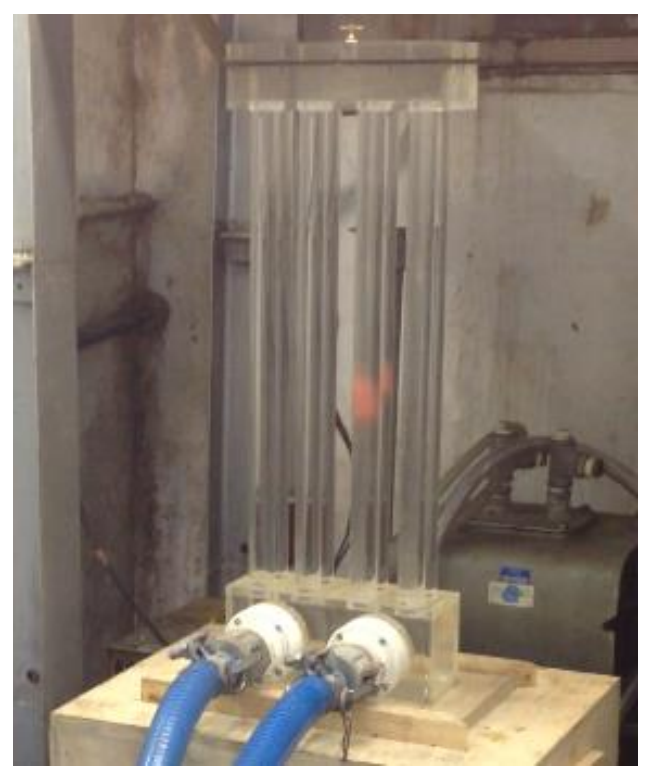

Figura 35 - Trocador de calor de acrílico utilizado para visualizar os ciclos de limpeza

\subsection{2}

\section{Avaliação de alternativas de pressurização do sistema}

O sistema de limpeza foi testado para três potências de pressurização, a seguir caracterizadas. Importante observar que uma vez calibrada a bomba hidráulica utilizada para pressurizar o sistema de limpeza, esta funciona como uma alternativa para medição da vazão do líquido de trabalho bombeado.

Conforme discutido no capítulo anterior, existem dados na literatura que confirmam que a eficácia do processo de limpeza por esferas abrasivas ocorre quando estas circulam pelo interior dos tubos obstruídos do trocador de calor a uma velocidade em torno de $2 \mathrm{~m} / \mathrm{s}$ (Bott, 1995). Entendendo que a velocidade de circulação das esferas pelos tubos do TC pode ser estimada pela velocidade média do fluxo de água de resfriamento (meio de transporte das esferas), por conveniência, optou-se por caracterizar as curvas de operação da bomba para diferentes rotações do seu rotor (calibração da bomba hidráulica contra um padrão de vazão), como dispositivo alternativo (prático) para se medir a velocidade média da esfera que se movimenta pelos tubos do trocador. O levantamento das curvas características de operação da bomba hidráulica instalada no equipamento de limpeza de trocadores de calor foi realizado na bancada do fabricante Dancor, equipada com um medidor de vazão calibrado. A título de ilustração, a Figura 36 apresenta informações do fabricante das curvas típicas deste tipo de bomba, para diferentes potências e diferentes diâmetros do rotor [3]. 


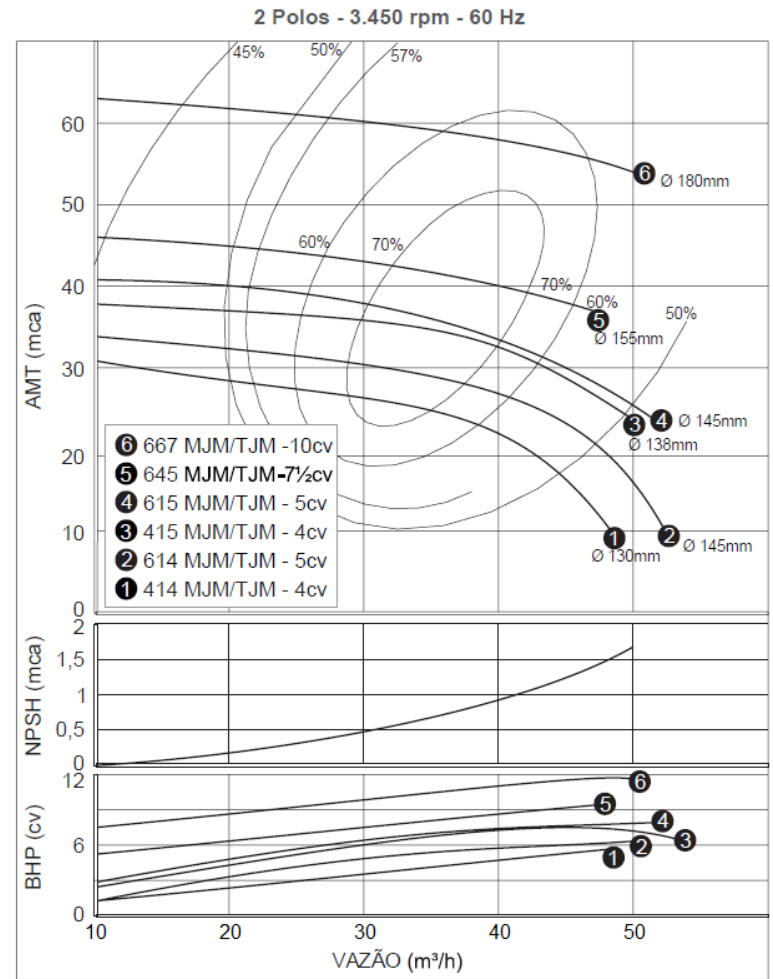

Figura 36 - Curvas de desempenho de bombas hidráulicas MJM/TJM

Fonte: DANCOR (2014)

Para adequar a capacidade de bombeamento do dispositivo de limpeza para diferentes portes de trocadores de calor, o dispositivo de limpeza foi concebido de forma a permitir que um mesmo dispositivo possa ser operado por bombas hidráulicas de diferentes potências. Consegue-se, assim, ajustar não apenas a pressão de trabalho para vencer a perda de carga imposta pelo trocador como, também, manter uma velocidade de circulação das esferas em torno de $2 \mathrm{~m} / \mathrm{s}$ (condição da eficácia do processo de limpeza), velocidade essa que pode ser ajustada variando-se a frequência do motor acoplado ao rotor da bomba, o que é conseguido pelo inversor de frequência acoplado ao grupo motor bomba.

Três configurações do dispositivo de limpeza são discutidas, a seguir:

- operado por bombas de baixa potência (e.g.: $4 \mathrm{cv}$ e $5 \mathrm{cv}$, adequados para trocadores de pequeno porte, a exemplo dos trocadores tubulares de equipamentos de injeção de plástico, com cerca de 40 tubos lisos, 6 passes, 16,60 $\mathrm{mm}$ de diâmetro interno e $650 \mathrm{~mm}$ de comprimento de tubo);

- operado por bomba de alto desempenho e alta potência (e.g.: $20 \mathrm{cv}$, adequado para a limpeza de trocadores de hidrogeradores (o sistema foi testado em um trocador de calor com 75 tubos aletados, montados em 6 passes, com diâmetro interno de $23 \mathrm{~mm}$ e comprimento de 2,0 m, utilizado no sistema de refrigeração de um hidrogerador em operação).

Nota: As três configurações estudadas são discutidas nas seções subsequentes. 


\subsubsection{1}

\section{Ensaio da bomba hidráulica (modelo 415 TJM 4 cv)}

O ensaio realizado na bomba hidráulica instalada no equipamento de limpeza, permitiu construir a curva característica da bomba (curva de desempenho: $\Delta p$ bomba (bar) $x$ vazão $\left(\mathrm{m}^{3} / \mathrm{h}\right)$, para diferentes rotações do rotor, conseguido variando-se a frequência do motor), mostrada na Figura 37. O dado $\Delta \mathrm{p}$ bomba equivale à altura manométrica da bomba. Previamente selecionadas, $\mathrm{O}$ ensaio foi realizado nas frequências $60 \mathrm{~Hz}, 55 \mathrm{~Hz}, 50 \mathrm{~Hz}, 45 \mathrm{~Hz}$ e $40 \mathrm{~Hz}$.

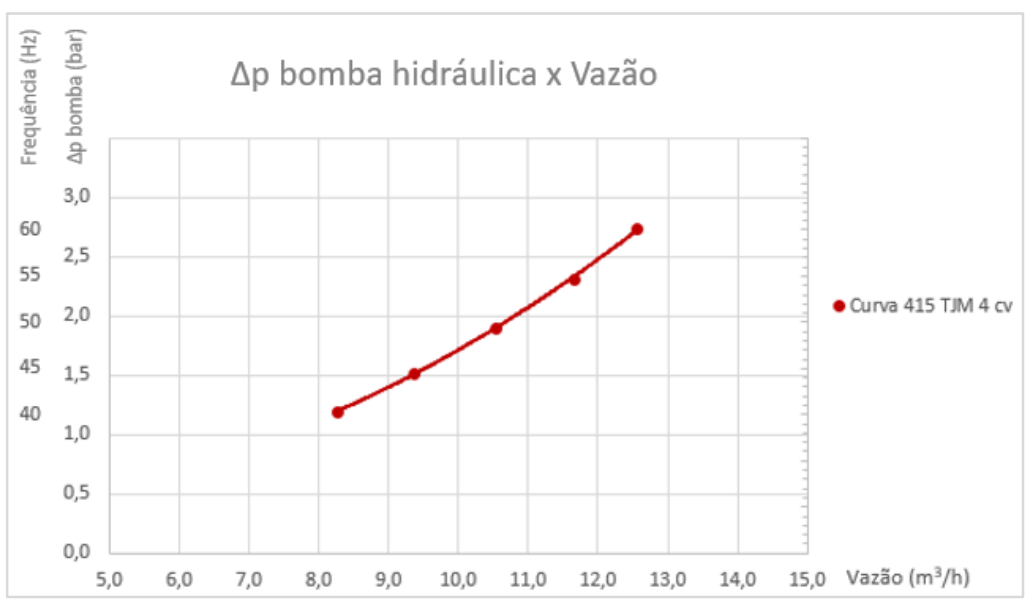

Figura 37 - Curva de Calibração da bomba modelo 415 TJM, 4 cv

Conforme mostrado acima, para um valor de diferença de pressão gerada pela bomba hidráulica (indicado na Figura 37 como $\Delta$ p bomba) de 2,7 bar (altura manométrica de $27 \mathrm{mca}$ ), a maior vazão que a bomba consegue entregar (12,6 $\mathrm{m}^{3} / \mathrm{h}$ ) ocorre na frequência de $60 \mathrm{~Hz}$, que é a frequência máxima suportada pela bomba hidráulica. O valor de vazão fornecido por essa bomba - modelo 415 TJM, $4 \mathrm{cv}$ - em sua frequência máxima de trabalho é insuficiente para o objetivo de 40 $\mathrm{m}^{3} / \mathrm{h}$, vazão desejada para cumprir requisitos satisfatórios de velocidade da esfera para uma boa limpeza dos tubos de trocadores.

\subsubsection{2}

\section{Ensaio da bomba hidráulica (modelo 615 TJM 5 cv)}

Analogamente ao ensaio realizado com a bomba Modelo 415 TJM, 4 cv, a bomba Modelo 615 TJM, $5 \mathrm{cv}$, foi ensaiada nas mesmas condições operacionais. O ensaio na frequência de $60 \mathrm{~Hz}$ foi repetido em duas situações, acoplado ao inversor de frequência e diretamente ligado na rede elétrica local (que opera em $60 \mathrm{~Hz}$, porém suscetível a flutuações por interferências externas). A Figura 38 documenta os resultados da calibração realizada. 


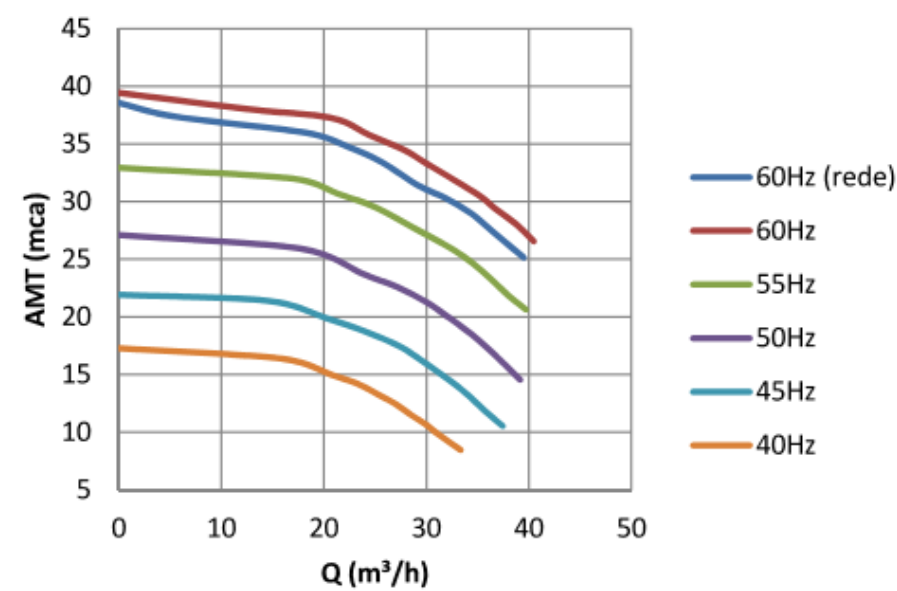

Figura 38 - Curvas de desempenho da família de bombas Dancor MJM/TJM

Conforme mostrado na Figura 38, a vazão de $40 \mathrm{~m} 3 / \mathrm{h}$ foi atingida apenas ao fim da curva de desempenho da bomba de potência superior à bomba instalada no sistema de limpeza. Essa condição de atingir a vazão deseja $\left(40 \mathrm{~m}^{3} / \mathrm{h}\right)$ apenas no fim da curva é inapropriada, pois força a bomba hidráulica trabalhar sempre no seu limite de desempenho, portanto fora da condição de projeto da bomba.

\subsubsection{3}

\section{Ensaio da bomba hidráulica (KSB, modelo 065-040-200, 20 cv)}

Os resultados dos ensaios com as bombas hidráulicas apresentados nas seções 4.3 .1 e 4.3 .2 mostraram que a vazão de $40 \mathrm{~m}^{3} / \mathrm{h}$ (requerida, por exemplo, para realizar a limpeza de trocadores de grande porte, como é o caso do trocador do hidrogerador da usina hidrelétrica Fontes Nova) não foi conseguida por nenhuma das duas bombas discutidas nas seções anteriores. Para que o mesmo equipamento de limpeza também possa ser acoplado a trocadores de calor de maior porte, uma bomba hidráulica de maior potência foi considerada e testada.

Geralmente, trocadores de calor de maior porte possuem um número maior de tubos, de maior comprimento, operados em múltiplos passes, resultando em perdas de carga mais elevadas, portanto requerendo maiores potências de bombeamento. Para atender a esses requisitos técnicos, o funcionamento do SIREA foi também testado com ele operado por uma bomba hidráulica de $20 \mathrm{cv}$ potência, do fabricante KSB, modelo 065-040-200.

Infelizmente esta etapa não foi possível de ser realizada devido à pandemia do COVID 19.

\section{4}

\section{Considerações sobre os ensaios de estanqueidade e funcionalidade}

A integridade da montagem do equipamento foi comprovada pelo ensaio de estanqueidade e de funcionamento acima descritos, que permitiram avaliar e 
corrigir pequenos vazamentos que sempre ocorrem em sistemas dessa complexidade. Após os ajustes realizados, o equipamento foi validado para uso sem apresentar qualquer vazamento em seus tramos hidráulicos, soldas, acoplamentos roscados das eletroválvulas e acoplamentos de instrumentos de medição de pressão, temperatura e vazão. Esses ensaios permitiram, também, ajustar os tempos de operação das eletroválvulas que controlam os circuitos hidráulicos do dispositivo de limpeza.

O ensaio hidráulico confirmou que os sistemas de controle de fluxo funcionaram conforme planejado, assegurando a circulação das esferas nos respectivos circuitos hidráulicos concebidos para cumprir a sua função, nos tempos programados (no modo manual, as esferas cumprem o ciclo de limpeza em um tempo máximo de 4,0 segundos). A válvula de 3 vias completa o seu processo de comutar da posição de injeção para a de recuperação, e vice e versa em um intervalo de tempo de 8,6 segundos.

Os ensaios de bomba realizados nos três modelos considerados mostraramse adequados para compatibilizar a capacidade de bombeamento do equipamento de limpeza às características e porte do trocador de calor que se deseja limpar.

\section{5 \\ Planejamento dos ciclos de limpeza}

O planejamento do ciclo de limpeza requer (i) dimensionamento do total de artefatos de limpeza a serem inseridos no dispositivo de limpeza para evitar o seu congestionamento nas chicanas do trocador, (ii) a definição do número ótimo de ciclos de limpeza capaz de assegurar que todos os tubos do TC sejam visitados pelas esferas abrasivas e (iii) o número de vezes que um mesmo tubo precisa ser visitado para garantir a eficácia de sua limpeza (retirada da incrustação acumulada).

\subsection{1}

\section{Definição do total de esferas}

Conforme mencionado, na indústria, diferentes portes e tipos de trocadores de calor são sistematicamente submetidos a processos de limpeza. A Figura 39 ilustra (i) o trocador de calor utilizado no sistema de injeção de plástico (identificado pelo número 1) e (ii) o compressor que injeta o fluido refrigerante na carcaça do trocador (identificado pelo número 2). A Figura 40 mostra os 40 tubos e a chicana do trocador de calor utilizado no equipamento de injeção de plástico, em operação nas instalações da Maroni Indústria Mecânica Ltda. 


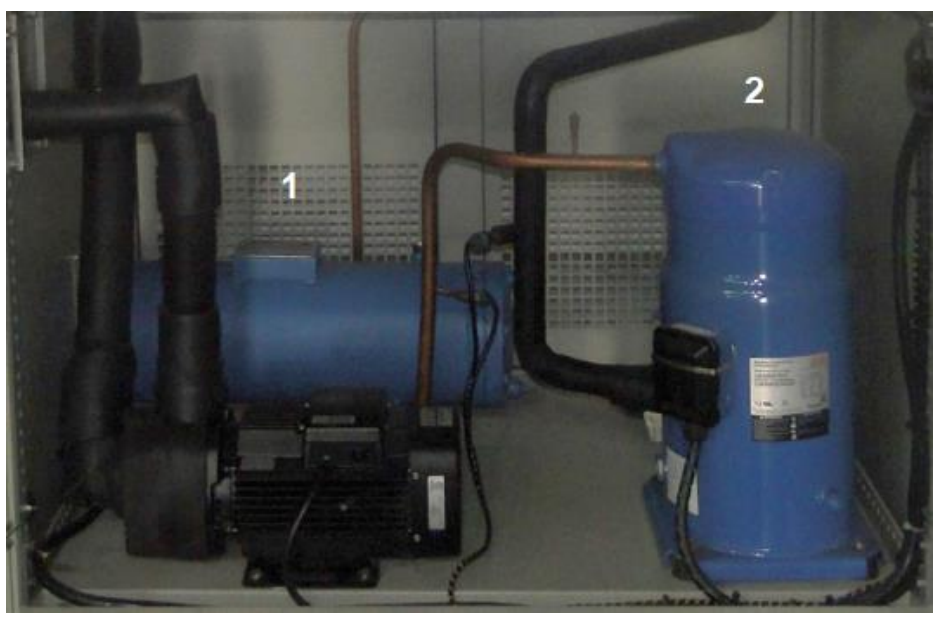

Figura 39 - Trocador de calor e compressor de um sistema típico de injeção de plástico
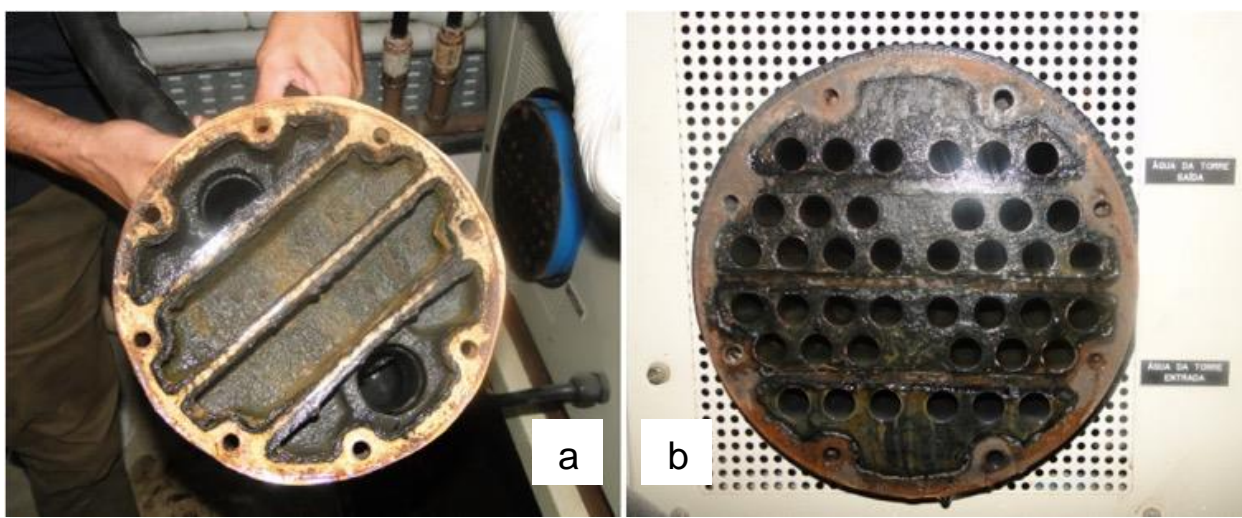

Figura 40 - Chicana (a) e tubos (b) do trocador de calor do sistema de injeção de plástico

A Figura 1 (mostrada na seção 1 do Capítulo 1) mostra um trocador de calor de maior porte que o anterior utilizado no sistema de arrefecimento de hidrogeradores. Para que fosse acoplado a este trocador de calor (Figura 1), o dispositivo de limpeza equipado com uma bomba hidráulica de alta potência (20 CV). A Figura 40 mostra as chicanas superior (Fig. 41a) e inferior (Fig. 41b), que orientam os fluxos de água em seis passes pelos 75 do trocador de calor, assim aumentando a área de troca de calor e o tempo de permanência das esferas dentro do trocador durante o processo de limpeza.

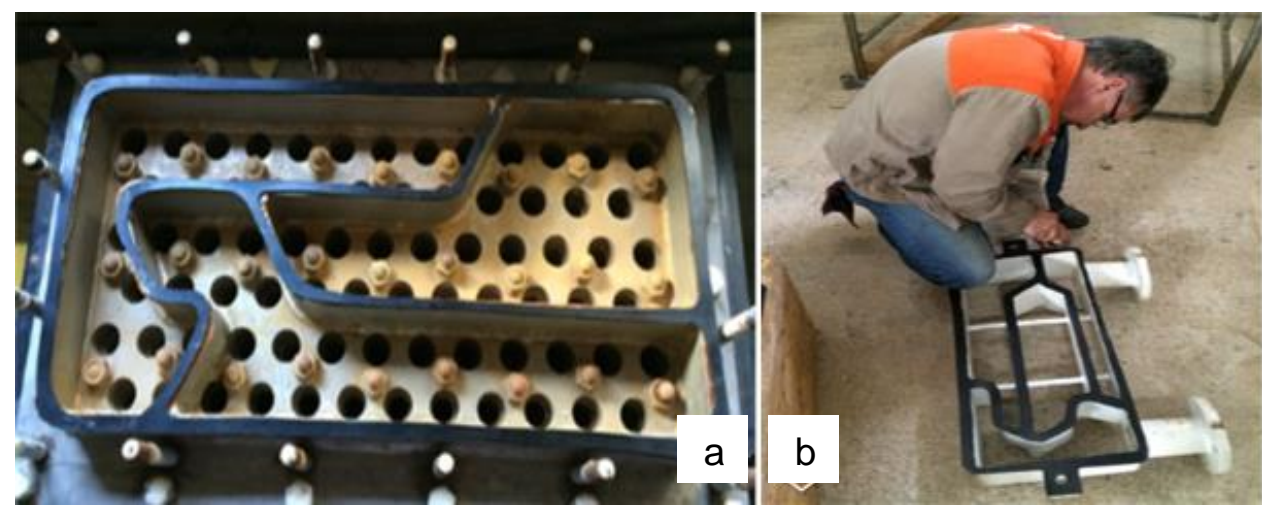

Figura 41 - Chicana superior (a) e inferior (b) do trocador de calor da usina Fontes Nova 
Importante destacar a importância das chicanas ${ }^{2}$ no trocador, pois são elas que direcionam o fluxo do fluido no interior do trocador de calor, ou seja, a direção e sentido do escoamento dentro de cada tubo. Quando o fluido de trabalho que circula pelo interior dos tubos do trocador (no presente caso, água) percorre uma vez o comprimento do trocador, o fluido completa o que se denomina um passe. Quando se aumenta o número de passes (para a mesma área transversal do trocador) aumenta-se o tempo de circulação do fluido dentro do trocador e, portanto, aumentando a troca de calor. O aumento de passes também impacta na troca de calor pelo fato do aumento da área de contato entre os fluidos (presentes no trocador), pois para mais passes sugerisse aumentar o número de tubos.

Com isso ressalta-se o impacto do aumento da área de contato entre os fluidos favorece a troca de calor por convecção (coeficiente de filme ou de película, no jargão da transferência de calor), com o consequente aumento da troca de calor total entre os fluidos. O número de passes resulta do projeto do trocador para que se consiga garantir a efetividade do trocador no desempenho de seu papel de resfriar o fluido quente (no presente estudo, o ar), que circula externamente aos tubos, em escoamento cruzado. Similarmente às chicanas, a carcaça do trocador cumpre um papel fundamental, pois permite que tubos de paredes finas e/ou os frágeis tubos aletados feitos de cobre sejam utilizados, assim assegurando elevada condutividade térmica (transferência de calor pelo mecanismo de condução). A Figura 42 mostra a região do fluxo do fluido na chicana superior $(A)$ e o sentido do fluxo na chicana inferior (B).
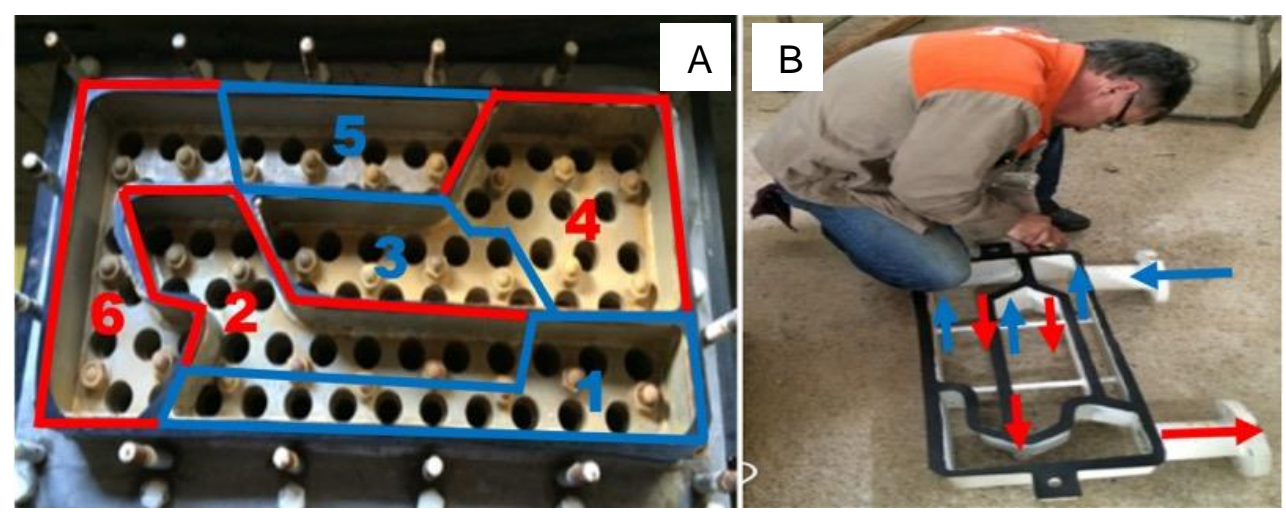

Figura 42 - Regiões de passe (A) e sentido do fluxo (B) no trocador de calor

$\mathrm{Na}$ parte A da Figura 42 observam-se os compartimentos associados aos passes do trocador, que partem da entrada do trocador de calor (chicana interior)

\footnotetext{
${ }^{2}$ Nos trocadores de calor, as chicanas têm por finalidade suportar os tubos, e garantir o direcionamento do fluxo do fluido de trabalho para um determinado conjunto de tubos, que caracterizam o passe do trocador. Embora um número maior de passes demande uma maior potência de bombeamento, esta alternativa aumenta a área de troca de calor entre os fluidos de trabalho do trocador, cumprindo o seu papel com maior efetividade.
} 
e findam na parte superior do trocador (chicana superior) - regiões destacadas em azul. Os passes de sentido contrário, i.e., da parte superior do trocador de calor para a parte inferior, são destacados nas regiões em vermelho. Os números dentro de cada região indicam a sequência do circuito realizado pelo fluido na chicana superior. A região sinalizada pelo número 1 corresponde ao primeiro passe dentro do trocador (da chicana inferior para chicana superior) e a região sinalizada pelo número 2 indica o passe subsequente. $O$ mesmo processo se repete para os demais compartimentos da chicana.

O lado B da Figura 42 mostra a chicana inferior com a entrada do trocador (seta em azul) e saída (seta em vermelho). As demais setas indicam o sentido do fluxo de água nos passes, nos compartimentos da chicana, mostrados na parte $A$ da Figura 42.

Conforme mencionado, o total de esferas abrasivas a serem introduzidas na câmara de injeção de esferas do dispositivo de limpeza deve ser determinado com cautela para assegurar eficácia do processo de limpeza. Estudos de visualização realizados por Müller-Steinhagen (2000) sugerem que o congestionamento das esferas nas chicanas pode ser minimizado se o total de esferas não exceder cerca de $10 \%$ a $30 \%$ do total de tubos por passe do trocador. Não obstante de interesse, esta informação é apenas uma recomendação que resultou da observação visual, mas este critério não responde a duas outras questões essenciais, a seguir formuladas:

- uma vez definido o número de esferas $\boldsymbol{n}$ a ser introduzido nos $\mathbf{N}$ tubos $(n<N)$ de um determinado passe do trocador, quantos ciclos independentes de limpeza $\boldsymbol{c}$ precisam ser realizados para assegurar que todos os tubos de cada passe do trocador sejam, de fato, visitados por pelo menos uma esfera?

- Uma vez determinado esse número $\boldsymbol{c}$ de ciclos de limpeza que garantem que todos os tubos do passe sejam visitados pelo menos uma vez por uma esfera abrasiva, qual deve ser o adicional $\boldsymbol{c}^{\prime}$ de ciclos de limpeza que precisam ser realizados para, de fato, assegurar a eficácia do processo de limpeza do trocador?

Esta seção do capítulo dedica-se a responder essas questões formuladas.

\subsection{2}

\section{Determinação do número mínimo de ciclos de limpeza}

Para responder à questão relacionada ao número mínimo de ciclos de limpeza necessários para garantir que todos os tubos do passe do trocador de calor sejam visitados pelo menos uma vez, por pelo menos uma esfera abrasiva, desenvolveu-se um estudo probabilístico que avalia o número de ciclos $\boldsymbol{c}$ que 
precisam ser realizados para que, dado um total $\boldsymbol{n}$ de esferas, pelo menos uma vez, os $\boldsymbol{N}$ tubos do passe do trocador de calor sejam visitados.

Para descrever uma variável aleatória discreta que representa um evento físico e, consequentemente, a sua probabilidade de ocorrência, há diversos modelos probabilísticos descritos na literatura (Kraft \& Eeden, 1968; Krishnaiah \& Sem, 1984), entre eles:

- Distribuição Bernoulli: modela um evento físico discreto, associado ao qual somente duas opções são possíveis, i.e.: acontecer o evento físico ou não acontecer o evento físico. No jargão da estatística clássica, a probabilidade $\boldsymbol{p}$ de acontecer um determinado evento é denominada de "sucesso". Já a probabilidade $\boldsymbol{q}(\boldsymbol{q}=1-\boldsymbol{p})$ de 0 evento não acontecer é denominada de "falha".

- Distribuição Binomial: modela $\boldsymbol{n}$ repetições de um evento Bernoulli com probabilidade de ocorrência $\boldsymbol{p}$.

- Distribuição Binomial Negativa: modela uma distribuição Bernoulli até acontecer o r-ésimo evento de sucesso. Assim, essa distribuição contém o parâmetro $r$, que denota o número mínimo de ocorrências do evento. Já o parâmetro $\boldsymbol{p}$ denota a probabilidade de um determinado evento acontecer.

Dentre as alternativas de modelos disponíveis, optou-se pelo modelo que descreve uma distribuição Binomial Negativa, já que este mostrou-se adequado ao estudo em pauta, ou seja, é capaz de descrever a probabilidade de as esferas abrasivas visitarem os tubos obedecendo os critérios acima descritos. A distribuição Binomial Negativa descreve o número de tentativas necessárias para se obter $\boldsymbol{k}$ sucessos de igual probabilidade $\boldsymbol{\theta}$ ao término de $\boldsymbol{\eta}$ experimentos de Bernoulli, sendo a última tentativa considerado como o evento de sucesso. Neste estudo considerou-se que, para um mesmo ciclo, todos os tubos de um mesmo passe possuem a mesma probabilidade de serem visitados por uma esfera.

Segundo o estudo experimental realizado por Müller-Steinhagen (2000), se o total de esferas inseridas na chicana pelo dispositivo de limpeza for, no máximo, $30 \%$ do total de tubos do passe, reduz-se a probabilidade de as esferas se chocarem entre si e gerar um indesejável congestionamento de esferas na chicana, o que atrapalharia a livre circulação das esferas pelos tubos do passe. Fundamentado nessa informação, os estudos probabilísticos, a seguir discutidos, adotou o fator de $30 \%$ como critério para se determinar o número máximo de esferas que devem ser introduzidas na chicana, em um determinado ciclo de limpeza. $O$ estudo de probabilidade fundamenta-se no modelo probabilístico de distribuição Binomial Negativa, cuja função de probabilidade é descrita pela Equação (5) (Conover, 1971). 


$$
f(x)=\operatorname{Pr}(X=x)=\left(\begin{array}{c}
x-1 \\
r-1
\end{array}\right) \cdot p^{r} \cdot(1-p)^{x-r}
$$

Sendo:

- $\quad x$ : o número total de ciclos de limpeza;

- domínio de $x=r, r+1, r+2, \ldots$

- $\quad r$ : o número mínimo (valor inteiro) de ciclos que devem ser realizados para que todos os tubos sejam visitados pelo menos uma vez por pelo menos uma esfera, i.e.: número de tubos por passe dividido pelo total de esferas $(N / n)$;

- $\quad p$ : probabilidade de um determinado tubo ser visitado, pelo menos uma vez, por uma esfera em um determinado ciclo de limpeza.

Com o objetivo de especificar o número de ciclos independentes de limpeza c que precisam ser realizados para assegurar que todos os tubos de cada passe do trocador sejam visitados por pelo menos uma esfera, a seguir, a Tabela 4 especifica os parâmetros de entrada da distribuição Binomial Negativa:

Tabela 4 - Parâmetros de entrada da distribuição Binomial Negativa

\begin{tabular}{|c|c|c|c|}
\hline Hipótese considerada & $\begin{array}{l}\text { Total de tubos por } \\
\text { passe do TC } \\
\text { (N) }\end{array}$ & $\begin{array}{c}\text { Total de esferas } \\
\text { utilizadas no ciclo de } \\
\text { limpeza } \\
\text { (n) }\end{array}$ & Número mínimo de ciclos \\
\hline $\begin{array}{c}\text { Total de esferas } \\
\text { utilizadas definida pelo } \\
\text { critério de } 30 \% \text { do } \\
\text { número de tubos } N \text { do } \\
\text { passe do TC } \\
\text { (i.e.: } \mathrm{n}=0,30 \mathrm{~N})\end{array}$ & $\mathrm{N}$ & 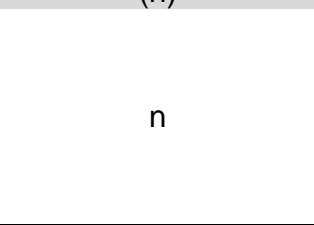 & $\begin{array}{c}r=N / n \\
\text { ou seja } \\
r=N / 0,3 \mathrm{~N} \\
\text { ou seja } \\
r=1 / 0,3=4\end{array}$ \\
\hline
\end{tabular}

* Número mínimo (valor inteiro) de ciclos que devem ser realizados para atender aos critérios do estudo; i.e.: que todos os tubos sejam visitados pelo menos uma vez por pelo menos uma esfera.

\subsubsection{1}

\section{Análise da eficácia do ciclo de limpeza}

Esta seção descreve o modelo probabilístico Binomial Negativa utilizado para se determinar o total mínimo de ciclos de limpeza que precisam ser realizados para assegurar que todos os tubos de um determinado passe do trocador de calor sejam visitados pelo menos uma vez, por uma das esferas introduzidas no dispositivo de limpeza. Este modelo avalia o que usualmente é denominado de "caso de falha" que ocorre, até acontecer o r-ésimo "evento de sucesso" (i.e.: todos os tubos do trocador de calor são visitados por, pelo menos, uma esfera). Ao se considerar este modelo, as seguintes hipóteses são consideradas:

1. o evento estudado é modelável pela distribuição probabilística Binominal Negativa;

2. o total de esferas injetadas na chicana do trocador é previamente definida como um percentual do total de tubos de cada passe do trocador de calor, $30 \%$ no caso; 
3. a probabilidade $\boldsymbol{p}$ associada à probabilidade de um determinado tubo ser visitado por um artefato de limpeza em cada ciclo. Essa probabilidade é calculada, no primeiro ciclo, pelo quociente entre o total de esferas injetadas e o número de tubos por passe do trocador de calor (como alguns passes podem ter mais tubos que outros, para efeito de cálculo, considera-se o maior valor do número de tubos);

4. as esferas circulam livremente, sem congestionamentos nos compartimentos da chicanas inferior e superior, e no interior dos tubos do trocador de limpeza.

Considerando as quatro condições acima caracterizadas, apresentam-se, a seguir, os parâmetros descritos na Equação (5) (seção 3.5.1) para o caso do trocador de calor selecionado. Ou seja, um dos seis trocadores de calor do sistema de refrigeração da unidade hidrogeradora $\mathrm{C}$ (44 MW) da usina hidrelétrica de Fontes Nova, de propriedade da Light Energia S/A, que, gentilmente, facilitou acesso às suas instalações.

Referindo-se à Equação (5) e utilizando um número de esferas correspondente a $30 \%$ do total de tubos do passe do trocador, os valores dos parâmetros que compõem a Binomial Negativa são definidos na Tabela 5:

Tabela 5 - Parâmetros associados à distribuição Binomial Negativa

\begin{tabular}{|c|c|c|c|}
\hline Hipótese considerada & $\begin{array}{l}\text { Número mínimo } \\
\text { de ciclos } \\
(r)\end{array}$ & $\begin{array}{l}\text { Probabilidade* } \\
\qquad(p)\end{array}$ & $\begin{array}{l}\text { Total de ciclos de } \\
\text { limpeza** } \\
(x)\end{array}$ \\
\hline $\begin{array}{c}\text { Total de esferas } \\
\text { utilizadas definida pelo } \\
\text { critério de } 30 \% \text { do } \\
\text { número de tubos } N \text { do } \\
\text { passe do } T C \\
\text { (i.e.: } \mathrm{n}=0,30 \mathrm{~N})\end{array}$ & (1) & $\begin{array}{c}0,308 \\
\text { (ou 30,8\%) }\end{array}$ & $4,5,6,7 \ldots$ \\
\hline
\end{tabular}

\footnotetext{
* Probabilidade de um determinado tubo ser visitado, pelo menos uma vez, por uma esfera em um determinado ciclo de limpeza.

** Inicia desde o valor mínimo de ciclos (i.e., $r=4$ ) e aumenta o seu valor em $r+1, r+2$ e assim por diante. O cálculo finaliza quando, calculada a Função de probabilidade acumulada, o resultado atinja o valor $100 \%$.
}

O número total de ciclos de limpeza é obtido quando a função acumulada da distribuição Binomial Negativa atinge o valor 100\% de probabilidade. Ou seja, para cada valor de $\boldsymbol{r}$ é calculada uma probabilidade absoluta $\left(\boldsymbol{p}_{\boldsymbol{r}}\right)$ que caracteriza a probabilidade de que todos os tubos sejam visitados por esse total de ciclos $r$. A função acumulada é obtida somando-se o valor da probabilidade $\boldsymbol{p}_{r}$ com o valor $\boldsymbol{p}_{\boldsymbol{r}}$ subsequente. Dessa forma, o valor de probabilidade acumula-se e, estatisticamente, deve atingir 100\%. Quando a probabilidade acumulada (ou função de probabilidade acumulada) atingir esse valor de 100\%, em sintonia como o objetivo originalmente formulado, não faz mais sentido continuar aumentando o número de ciclos, uma vez que já está assegurada a hipótese desejada de que todos os tubos sejam visitados, pelo menos, uma vez. 
À medida que alguns tubos vão sendo visitados por um artefato de limpeza, estes passam a oferecer menor resistência ao escoamento do fluido num ciclo subsequente, atribuindo-lhe maior probabilidade de ser revisitado quando comparado a um tubo do mesmo passe que ainda não foi visitado. Por essa razão, em princípio, este tubo já visitado por uma esfera pode ser "mais atrativo" para ser revisitado por outra esfera já que esta, naturalmente, percorrerá o caminho que oferece menor resistência ao escoamento. Para emular o efeito dessa menor probabilidade de os tubos menos limpos serem visitados, foram aplicadas penalidades à probabilidade desses tubos serem visitado por esferas. Embora ter sido utilizado um critério de penalidade para atenuar o impacto hidrodinâmico, a análise probabilística realizada não considerada o efeito global localizado da mecânica dos fluidos associada ao fluxo global do fluido que transporta as esferas pelos tubos do passe do trocador. Ou seja, não considera o aspecto hidrodinâmico associado ao fato de um tubo já visitado por uma esfera em um determinado ciclo de limpeza oferecer menor resistência ao escoamento no ciclo subsequente, já que foi parcialmente limpo pela passagem da esfera no ciclo anterior.

Com o propósito de considerar esse efeito na análise probabilística desenvolvida, aplicou-se um "critério de penalidade". Ou seja, considerando o fato que os tubos que não foram visitados por uma esfera em um primeiro ciclo têm uma probabilidade menor de serem visitados em um ciclo subsequente (isto devido ao comportamento hidrodinâmico do escoamento), assume-se que, à medida que se aumenta o número de ciclos, existe uma redução na probabilidade de os tubos serem visitados por uma esfera. Para facilitar a aplicação do modelo estatístico, essa diminuição da probabilidade é considerada igual para todos os tubos, uma vez que, o modelo tem a limitação de reconhecer quais tubos têm sido visitados em cada ciclo. Assim, a probabilidade $\boldsymbol{p}$ de um determinado tubo ser visitado, pelo menos uma vez, por uma esfera em um determinado ciclo de limpeza é reduzida a uma probabilidade $\boldsymbol{p}$ 'para cada ciclo subsequente.

A determinação do valor p'é dada pela Equação (6).

$$
p^{\prime}=p\left(1-p_{\text {penalidade }}\right)
$$

Os valores de penalidade ( $\left.p_{\text {penalidade }}\right)$ foram analisados para nove situações distintas, i.e.: $0 \%, 10 \%, 20 \%, 30 \%, 40 \%, 50 \%, 60 \%, 70 \%$ e $80 \%$. Espera-se que, à medida que o valor da penalidade aumenta (probabilidade de a esfera revisitar um determinado tubo já visitado) o número de ciclos de limpeza necessários para garantir que todos os tubos serão visitados, pelo menos, uma 
vez, também aumente. Nesta dissertação de mestrado, isto foi verificado estatisticamente, produzindo-se resultados coerentes.

\subsubsection{2}

\section{Probabilidade de todos os tubos serem visitados uma única vez}

O detalhamento dos cálculos estatísticos realizados com base no fundamentado na Binomial Negativa (Kraft \& Eeden, 1968; Krishnaiah \& Sem, 1984), encontra-se apresentado nas tabelas do Apêndice A cujos resultados foram obtidos fazendo uso da ferramenta de análise de dados disponíveis no software Microsoft Office Excel. Esta ferramenta permite realizar o cálculo de probabilidades associados ao modelo Binomial Negativa, o que torna prático a solução da equação (5), a partir dos parâmetros de entrada.

Os resultados consolidados na Tabela 6 indicam, para os diferentes níveis de penalidade considerados, o número mínimo de ciclos de limpeza que precisam ser realizados para garantir que cada tubo de um mesmo passe do trocador seja visitado pelo menos uma vez por uma esfera abrasiva (artefato de limpeza). A tabela também define a penalidade $p$ ' aplicada à cada ciclo subsequente. Assim levando em conta a condição hidrodinâmica relacionada ao fato de que uma vez visitado por uma esfera abrasiva (que remove parte da incrustação em um determinado tubo), ele oferece menor resistência ao escoamento da esfera em um ciclo subsequente.

Tabela 6 - Estudo de ciclos de limpeza

\begin{tabular}{c|c|c}
\hline $\begin{array}{c}\text { Penalidade } \\
\text { aplicada penalidade } \\
(\%)\end{array}$ & $\begin{array}{c}\text { Probabilidade após } \\
\text { penalidade } p^{\prime}\end{array}$ & $\begin{array}{c}\text { Total de ciclos } \\
\text { de limpeza }\end{array}$ \\
0 & $0,308(30,8 \%)$ & 39 \\
10 & $0,277(27,7 \%)$ & 36 \\
20 & $0,246(24,6 \%)$ & 39 \\
30 & $0,215(21,5 \%)$ & 44 \\
40 & $0,185(18,5 \%)$ & 51 \\
50 & $0,154(15,4 \%)$ & 62 \\
60 & $0,123(12,3 \%)$ & 77 \\
70 & $0,092(9,20 \%)$ & 104 \\
80 & $0,062(6,20 \%)$ & 158 \\
\hline
\end{tabular}

Como era de esperar, à medida que se aumenta o percentual da penalidade aplicada, aumenta-se, também, o número mínimo de ciclos que devem ser realizados para garantir que todos os tubos sejam visitados por uma esfera, pelo menos uma vez. A primeira coluna da Tabela 6 denota o valor percentual inserido no modelo probabilístico, que representa a dificuldade de uma esfera passar pelos tubos que não foram visitados em um determinado ciclo (devido às restrições 
hidrodinâmicas). Já a segunda coluna da tabela, denota a probabilidade de uma esfera visitar um tubo de forma aleatória. Finalmente, a terceira coluna denota o total de ciclos de limpeza necessários para garantir — sob condição de penalidade — que todos os tubos serão visitados, pelo menos, uma vez.

Da análise dos dados da Tabela 6, observa-se que, para penalidades acima de $20 \%$, o total de ciclos que suporta a hipótese (i.e.: que todos os tubos do passe sejam visitados por uma esfera, pelo menos uma única vez) aumenta significativamente. A Figura 43 ilustra os resultados da análise probabilística realizada, para os diferentes graus de penalidade considerados.

Contrastando com este estudo que atribuiu penalidades iguais a todos os tubos do passe, acredita-se que um estudo probabilístico mais representativo do problema físico em pauta possa ser aprimorado com base em estatística Baysean $^{3}$, que poderia considerar probabilísticas distintas de percursos a serem perseguidas pelos artefatos de limpeza, desdobramento este, entretanto, sugerido para trabalhos futuros.

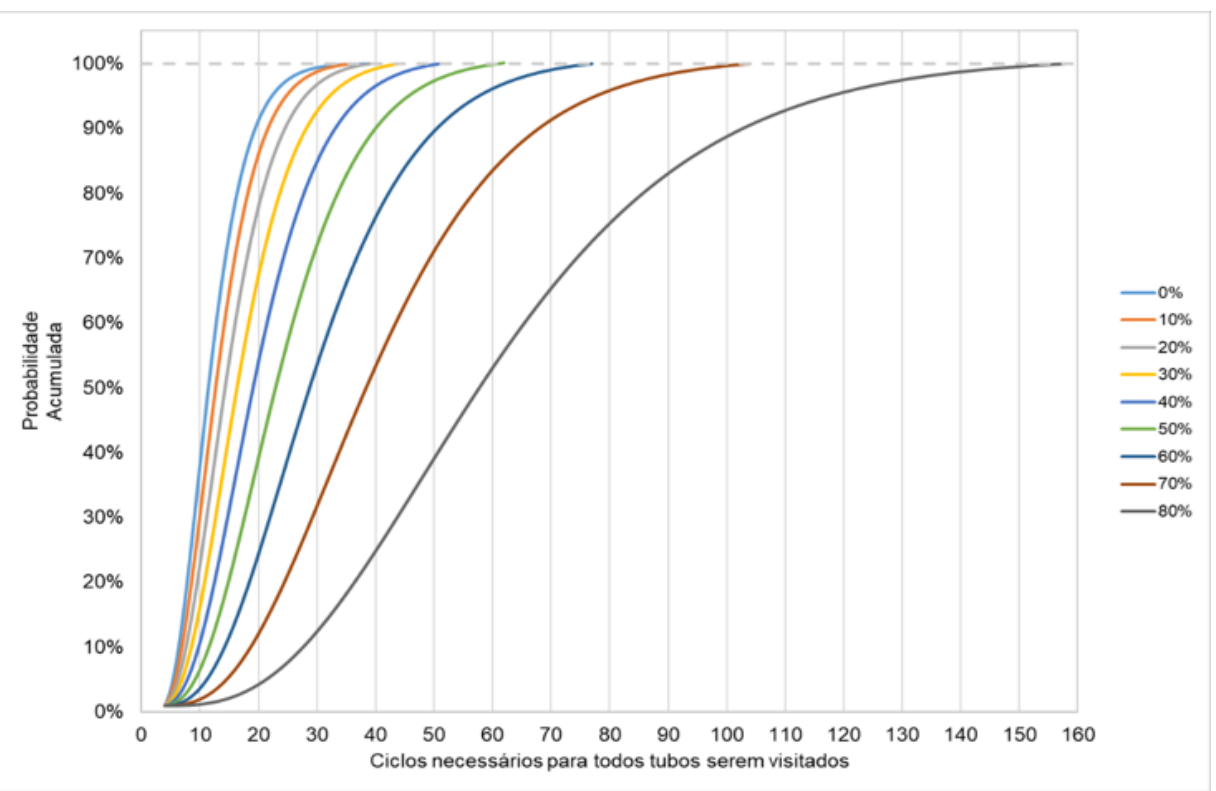

Figura 43 - Relação de ciclos para condição de êxito por penalidade aplicada

A Figura 44 ilustra o comportamento não linear da penalidade versus total de ciclos mínimos para se garantir a hipótese de que todos os tubos de um mesmo passe do trocador sejam visitados por uma esfera, pelo menos uma única vez.

${ }^{3}$ Estatística Bayesiana é um ramo da estatística que usa o termo probabilidade, da mesma forma que o termo é utilizado diariamente, como uma medida condicional da incerteza $P(E / D)$ associada com a ocorrência de um evento $E$, dada a informação disponível $D$. Logo, $P(E / D)$ é uma medida da crença de ocorrência do evento $E$ quando ocorrem as condições resumidas nos dados $D$. A estatística bayesiana reduz qualquer problema de inferência estatística a um problema em teoria de probabilidades já bem definido, reduzindo a necessidade da criação de novos conceitos, em que a incerteza de um problema é descrita através de probabilidades, cujos parâmetros do modelo são tratados como aleatórios (a aleatoriedade denota uma descrição da incerteza dos valores verdadeiros) [Introduction to Bayesian Statistics - William Bolstad, 2016]. 


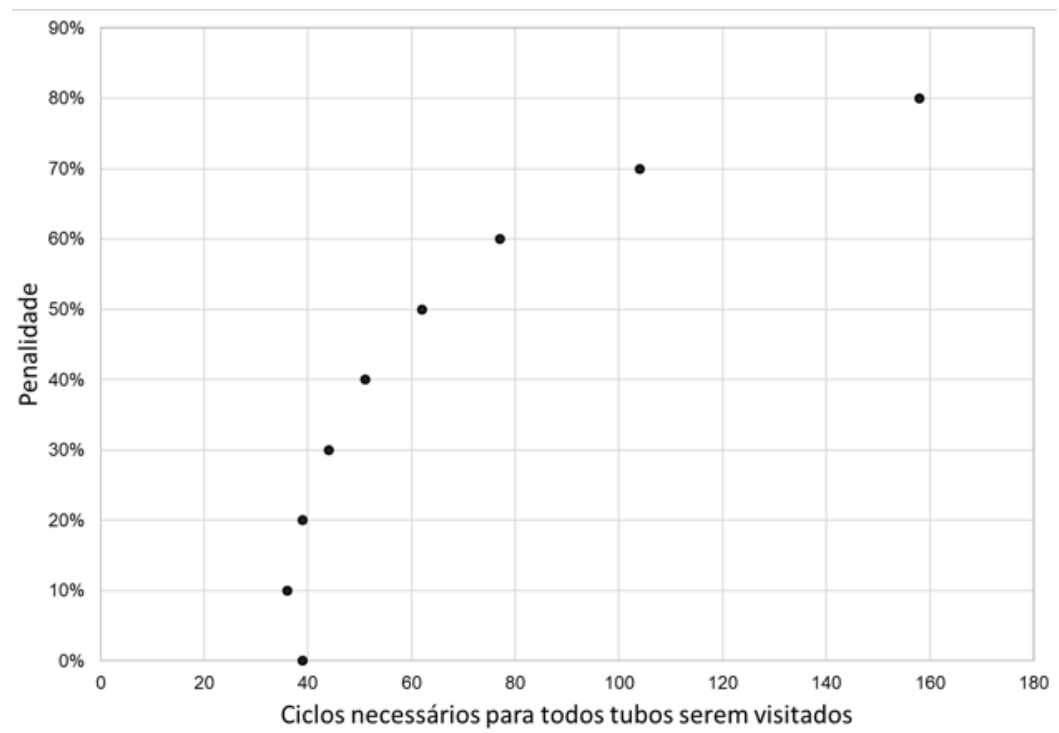

Figura 44 - Penalidade $x$ ciclos de limpeza

Conforme mostrado, um número elevado de ciclos de limpeza precisa ser realizado para assegurar o caráter básico do processo de limpeza, ou seja, que todos os tubos do trocador sejam visitados (pelo menos uma vez) pelo artefato de limpeza. Somente este fato já justificaria a automação do dispositivo de limpeza.

\subsubsection{3}

\section{Total adequado de ciclos de limpeza}

Uma vez definido o número mínimo de ciclos para assegurar que todos os tubos foram visitados por artefatos de limpeza pelo menos uma vez, cabe aqui uma outra questão, quantos ciclos de limpeza precisam ser realizados para assegurar a eficácia do processo de limpeza dos tubos do trocador? Parece razoável se supor (e a experiência comprova esse fato), que uma única passagem da esfera por um determinado tubo do trocador de calor pode não ser suficiente para exercer o "efeito de escovamento" requerido para remover toda a incrustação nele depositada. Importante aqui deixar claro que o estudo probabilístico desenvolvido responde apenas à primeira parte do questionamento, ou seja, orienta a determinação do número mínimo de ciclos que assegura que todos os tubos sejam visitados pelo menos uma única vez. A determinação, entretanto, do número de ciclos necessários para assegurar a limpeza do trocador como um todo é assegurada pelo monitoramento, em tempo real, da efetividade do trocador, conforme discutido em outra pesquisa de mestrado que se desenvolve em paralelo (Pacheco, 2020), pelo mesmo grupo de pesquisa. 


\section{4}

\section{Sistema de medição embarcado no dispositivo de limpeza}

Este capítulo apresenta o resultado da validação dos distintos subsistemas complementares do sistema de medição embarcado no dispositivo de limpeza de trocador de calor (do tipo tubular), referenciado neste trabalho pela sua sigla SIREA 3 (terceira versão do protótipo desenvolvido pelo Programa de PósGraduação em Metrologia da PUC-Rio). O capítulo discute a confiabilidade metrológica do sistema de medição integrado e desenvolve algoritmos para calcular as respectivas incertezas associadas à medição das grandezas físicas envolvidas (frequência do dispositivo optoeletrônico do contador de esferas e medições de velocidade, vazão, temperatura e pressão do fluido de trabalho do trocador).

\section{1}

\section{Confiabilidade metrológica do sistema de medição}

Quatro são as principais fontes de incerteza que influenciam a incerteza expandida $\left(U_{E}\right)$ associada à medição realizada pelo instrumento calibrado, no seu cálculo, descritas pela Equação (5). São elas: (i) incerteza associada à resolução do instrumento submetido à calibração $\left(U_{\text {inst }}\right)$; (ii) incerteza associada ao padrão de medição $\left(U_{p}\right)$; (iii) incerteza associada à repetibilidade da medição indicada pelo instrumento de medição $\left(U_{r}\right)$ e (iv) incerteza associada ao polinômio de ajuste $\left(U_{s}\right)$. Esses componentes da incerteza são expressos pela Equação (7), que permite calcular a incerteza global expandida.

$$
U_{E}^{2}=U_{\text {inst }}^{2}+U_{p}^{2}+U_{r}^{2}+U_{s}^{2}
$$

\subsection{1}

\section{Componente associado à resolução do instrumento}

A incerteza expandida associada à resolução do instrumento é calculada pela Equação (8):

$$
U_{\text {inst }}=k \cdot u_{\text {inst }}=k \cdot \frac{\text { Resolução }}{2 \sqrt{3}}
$$

Nesta equação, $k$ é o fator de abrangência, obtido de uma distribuição de probabilidade t-Student (para um nível de confiança de 95,0\%), para um determinado número de graus de liberdade 4 .

${ }^{4}$ Número de graus de liberdade $\varphi$ é dado pela diferença entre número de possibilidades (número de pontos experimentais $\boldsymbol{n}$ ) e o número de restrições impostas (no caso de uso de polinômios de ajuste, o número de restrições é dado pelo número de coeficientes do polinômio). 


\subsection{2}

\section{Componente associado ao padrão utilizado}

A incerteza expandida associada ao padrão encontra-se documentada no Certificado de Calibração do padrão utilizado na calibração de cada instrumento de medição, que também documenta o respectivo valor considerado do fator de abrangência para um determinado nível de confiança.

\subsection{3}

\section{Componente associado à repetibilidade da medição}

Em conformidade ao Vocabulário Internacional de Metrologia (VIM, 2012), a repetibilidade da medição associada a um determinado experimento de calibração pode ocorrer segundo cinco condições de repetibilidade, a saber: “... (i) o mesmo procedimento de medição; (ii) os mesmos operadores; (iii) o mesmo sistema de medição; (iv) as mesmas condições de operação e (v) o mesmo local, assim como medições repetidas no mesmo objeto durante um curto período de tempo ...".

A incerteza associada à repetibilidade é calculada pela razão entre o desvio padrão amostral $s$ e a raiz quadrada das $n$ réplicas da medição do experimento, dada pela Equação (9):

$$
u_{r}=\frac{s}{\sqrt{n}}
$$

Lembrando que o desvio padrão amostral s é dado pela Equação (10):

$$
s=\sqrt{\left(\frac{1}{n-1}\right) \cdot \sum_{i=1}^{n}\left(x_{i}-\bar{x}\right)^{2}}
$$

Nesta expressão, $\boldsymbol{x}_{\boldsymbol{i}}$ é o resultado da medição experimentalmente obtido e $\bar{x}$ é a média amostral, calculada pela Equação (11):

$$
\bar{x}=\left(\frac{1}{n}\right) \cdot \sum_{i=1}^{n} x_{i}
$$

A incerteza expandida associada à repetibilidade é calculada pela Equação (12):

$$
U_{r}=k \cdot u_{r}
$$

Já o fator de abrangência $k$ é determinado a partir de uma distribuição $t$-Student de probabilidade para um nível de confiança de 95,0\%. 


\subsection{4}

\section{Componente da incerteza associada ao ajuste pelo polinômio}

Para correlacionar o valor lido pelo instrumento a ser calibrado com o respectivo valor indicado pelo padrão, utiliza-se um polinômio de grau $m$ (Equação (13)), para cada experimento da calibração realizada. O polinômio que oferece a menor incerteza de ajuste é o que mais bem representa a natureza física da calibração, portanto selecionado como sendo o polinômio de ajuste da calibração. Contudo, é preciso atentar à natureza da grandeza medida, pois não há sentido físico em expressar uma grandeza com um polinômio de grau elevado, 10 por exemplo. Por conta disso uma boa prática é utilizar polinômios com coeficientes igual ou menor a quatro.

$$
y\left(x_{i}\right)=a_{0}+a_{1} \cdot x+a_{2} \cdot x^{2}++a_{3} \cdot x^{3}+\cdots+a_{n} \cdot x^{m}
$$

A utilização de um polinômio de ajuste para correlacionar valores lidos pelo instrumento com sua respectiva curva de calibração apresenta uma vantagem de caráter prático, notadamente quando se deseja automatizar a medição para transmissão remota via sistema auxiliar de processamento e transmissão de dados.

Na Equação (13), x é o resultado da medição indicada pelo instrumento e $y\left(x_{i}\right)$ o valor ajustado pelo polinômio, valor esse que relaciona a leitura do instrumento ao valor indicado pelo padrão.

Os coeficientes $a_{0}, a_{1} \cdots a_{m}$ são determinados aplicando-se o método dos mínimos quadrados ordinários i.e.: resolvendo o sistema matricial dado pela Equação (14). De forma conveniente e alternativa, uma função do software Excel permite determinar esses coeficientes do polinômio de ajuste, assim evitando o trabalho algébrico requerido para resolver o sistema de Equação (14):

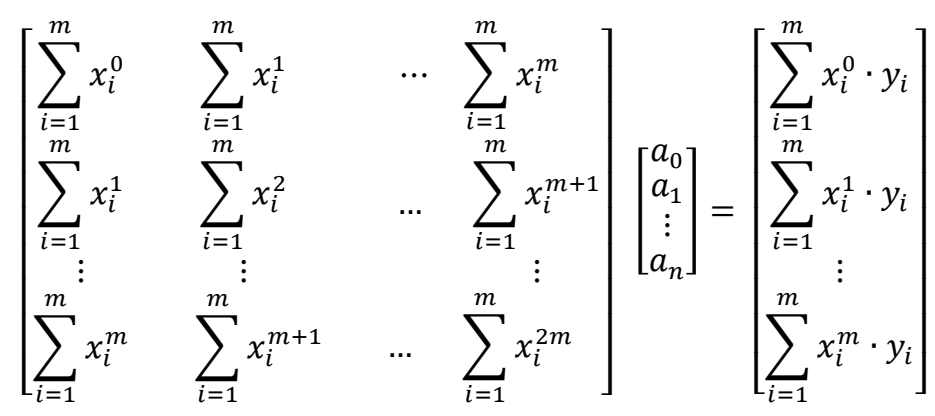

Um polinômio de grau $1(m=1)$ pode constituir-se em uma boa representação da natureza física da calibração de determinados tipos de instrumentos de medição. A escolha de polinômios de grau superior pode resultar 
em menores incertezas de ajuste. Por conta disso, uma boa prática de calibração é verificar pelo menos três graus de polinômio para se definir qual deles oferece a menor incerteza associada ao polinômio de ajuste. Uma vez determinados os coeficientes para cada polinômio, calculam-se os valores ajustados para cada polinômio $m=1 ; m=2$ e $m=3$.

A aplicação de um polinômio de ajuste permite: (i) corrigir os resultados experimentais medidos pelo instrumento de medição; (ii) diminuir o erro sistemático, que é inerente ao processo de medição e (iii) estimar os valores ajustados para qualquer indicação do instrumento, desde que estes estejam dentro da faixa de sua calibração. Tendo em vista as vantagens de se utilizar o polinômio de ajuste para corrigir o valor indicado pelo instrumento, não se pode deixar de considerar que o seu uso introduz nova fonte de incerteza, polinômio esse, entretanto, que contribui para a melhoria da qualidade da medição. Embora o uso de coeficientes de graus superiores ofereça um menor erro de ajuste (i.e.: diferença entre um valor medido e um valor calculado pelo ajuste polinomial), isto não garante que a incerteza do ajuste seja menor quanto maior for o grau do polinômio. Isto pode ser explicado pelo cálculo da incerteza de ajuste, que considera, na sua concepção matemática, o número de graus de liberdade ( $\varphi=$ $n-t$ ), parâmetro esse que depende: (i) do número de pontos experimentais $(\boldsymbol{n}) \mathrm{e}$ (ii) do número de coeficientes estimados por cada polinômio $(\boldsymbol{t})$.

O valor desta incerteza associada ao polinômio de ajuste é calculado para cada polinômio avaliado aplicando-se a Equação (15):

$$
u_{s}=\sqrt{\left(\frac{1}{n-t}\right) \cdot \sum_{i=1}^{n}\left[y\left(x_{i}\right)-y_{i}\right]^{2}}
$$

Na equação 15:

- $u_{s}$ : incerteza do polinômio de ajuste;

- $y\left(x_{i}\right)$ : valor ajustado pelo polinômio;

- $y_{i}$ : valor indicado pelo padrão;

- $n$ : número de pontos experimentais (pontos de calibração);

- $t$ : número de coeficientes do polinômio de ajuste avaliado.

Na sequência, (i) escolhe-se o polinômio de ajuste pelo polinômio associado à menor incerteza de ajuste e (ii) determina-se o fator de abrangência $k$ (para um nível de confiança de 95,0 \%), a partir da distribuição de probabilidade $t$-Student e do número de graus de liberdade $(\varphi)$, dado pela Equação (16):

$$
\varphi=n-t
$$


Nesta equação, $n$ denota o número de pontos experimentais da calibração e $t$ o número de coeficientes estimados pelo polinômio. Já a incerteza expandida associada ao ajuste pelo polinômio é dada pela Equação (17):

$$
U_{s}=k \cdot u_{s}
$$

Importante destacar o papel do fator $k$ nesta equação. Ele atua no sentido de estabelecer um "reescalonamento" do valor calculado da incerteza padrão (fazendo-se a hipótese de que a base de dados representa uma distribuição normal, i.e.: Gaussiana). Como a incerteza combinada deve ser interpretada como o equivalente a um desvio padrão (o que equivale a um intervalo de confiança de $68,0 \%$ ), ao se multiplicar este resultado pelo valor $k=2$ do fator de abrangência, o valor da incerteza associada é expandido para um nível de confiança de 95,45\%, daí o nome "incerteza expandida". Quando necessário para atender tolerâncias mais rígidas pelo demandante da medição, resultados ainda mais conservadores da incerteza podem ser expressos aplicando-se um fator de abrangência ainda maior (e.g.: o fator de abrangência $k=2,58$ amplia o intervalo de confiança para 99,0\%).

\subsection{5 \\ Critério de Chauvenet para exclusão de outliers}

Em uma situação na qual o conjunto de ensaios de uma amostra apresenta um ou mais valores discrepantes dos demais, compete ao experimentalista decidir se deve ou não considerar os dados suspeitos no tratamento estatístico dos dados. Essa decisão é fundamental, pois estes dados influenciarão diretamente os valores da média, exatidão, e desvio padrão, valores esses que também impactam diretamente na incerteza associada às medições realizadas.

Do ponto de vista estatístico, não é recomendada a exclusão de mais de dois dados ao se trabalhar com amostras pequenas $(n \leq 30)$. Se, após rejeição de dois valores, ainda existirem possíveis outliers, recomenda-se a investigação da causa do problema e, por precaução, a aquisição de um novo conjunto de dados.

O critério de Chauvenet - William Chauvenet (Chauvenet, 1868) - reflete um conceito conservador, mostrando-se eficaz para eliminar este problema. É um critério simples de ser calculado, muito prático e amplamente utilizado por diversos especialistas da área, visando à detecção e eliminação de valores outliers associados a um sistema de medição (Maples et al., 2018) (Zihao et al., 2019) (de Oliveira et al., 2016). O princípio do critério é mostrado na Equação (18). 


$$
\left|d_{j}\right|=\left|\left(y_{j}-\bar{y}\right)\right|>d_{c h}
$$

Na equação 18:

$d_{c h}$ : limite de rejeição de Chauvenet, definido nas Equações (19), (20) e (21):

$$
p_{0}=\int_{-\infty}^{-d_{c h}} G(\eta) d \eta+\int_{d_{c h}}^{+\infty} G(\eta) d \eta=\int_{-d_{c h}}^{d_{c h}} G(\eta) d \eta=\frac{1}{2 n}
$$

Enquanto na Equação (19):

$G(\eta)$ : função Gaussiana;

$n$ : número de pontos experimentais (pontos de calibração).

Em outras palavras, esta formulação especifica que uma leitura pode ser rejeitada se a probabilidade de o seu valor desviar da média de um valor menor do que $1 / 2 n$. Esse critério estabelece que uma medida $x_{i}$ deve ser rechaçada se o valor de $\boldsymbol{r}$ calculado pela Equação (20) for maior que o valor crítico $\boldsymbol{R} \boldsymbol{c}$ calculado na Equação (21).

$$
r=\frac{\left|x_{i}-\bar{X}\right|}{s(X)}
$$

Na equação (20):

$x_{i}$ : valor de medição;

$\bar{X}$ : média da amostra;

$s(X)$ : desvio padrão da amostra.

$$
R c=I N V \cdot N O R M P \cdot N\left(1-p_{o} / 2\right)
$$

$\mathrm{Na}$ Equação (21):

$\boldsymbol{R} \boldsymbol{c}$ : valor crítico (pode ser calculado no Excel com a função de: inverso da distribuição cumulativa normal padrão. A distribuição possui uma média igual a zero e um desvio padrão igual ao valor unitário 1).

\section{2}

\section{Funções operacionais e subsistemas de medição do SIREA 3}

Antes de caracterizar o sistema de medição embarcado na versão 3.0 do SIREA (SIREA 3), cabe destacar que esta versão do equipamento desenvolvido foi ampliada para operar duas funções distintas: (i) inserir e recuperar as esferas abrasivas utilizadas para desobstruir os tubos do trocador de calor tubular (função "dispositivo de limpeza de trocadores de calor") e (ii) atuar como um calibrador automatizado de sensores de pressão e de medidores de vazão (função "Calibrador"). A primeira função reflete o objetivo principal do SIREA (i.e.: limpar trocadores de calor sem a necessidade de interromper a geração de energia, 
portanto evitando a parada técnica do hidrogerador ao qual o trocador de calor a ser limpo está trabalhando em conjunto). A segunda função resultou de uma adaptação que aproveita os instrumentos embarcados e o sistema de aquisição, transmissão de dados e de automação, capacitando o SIREA 3 a operar como um calibrador extremamente prático e confiável para gerar, em modo automático, um grande número de réplicas dos experimentos de calibração. Isso contribui para a melhoria da confiabilidade metrológica da calibração dos subsistemas de medição (i.e.: contador de esferas, vazão, pressão e temperatura). A seção 4.2 concentrase na calibração dos instrumentos de medição embarcados no SIREA 3 para desempenhar a sua função principal, ou seja, a função de operar como dispositivo de limpeza de trocadores de calor. Esta seção discute a calibração dos quatro subsistemas de medição embarcados no SIREA 3, a seguir caracterizados:

- Subsistema Contador de esferas, que também funciona como medidor de vazão do fluido de trabalho do trocador (meio de transporte das esferas) e de velocidade das esferas abrasivas utilizada no sistema de limpeza;

- Subsistema de medição de vazão, do tipo magnético, para medição do fluxo de água;

- Subsistema de medição de pressão (transdutores de pressão do tipo resistivo) para medição de pontos cruciais do dispositivo de limpeza;

- Subsistema de medição de temperatura (termorresistências do tipo Pt 100), para medição da temperatura dos fluidos de trabalho do trocador.

Em conformidade ao conceito de calibração de um instrumento de medição, esta ocorre por comparação direta do valor indicado pelo instrumento objeto da calibração com o valor indicado por um padrão (calibrador) de hierarquia superior. Em conformidade às recomendações do Guia Internacional para expressão da incerteza de medição (ISO GUM, 2008), desenvolveu-se um tratamento estatístico dos resultados da calibração de cada instrumento de medição instalado no sistema, análise essa que requer conhecimento de dados relatados nos respectivos Certificados de Calibração de cada um dos padrões utilizados para assegurar lastro da calibração. Mais especificamente, constam desses certificados o fator de abrangência associado aos graus de liberdade do processo de calibração e a incerteza associada à calibração do padrão. Somente diante dessas informações é que se consegue expressar a incerteza expandida associada à medição, realizada por cada um dos instrumentos de medição embarcados no SIREA 3.

No contexto da confiabilidade metrológica de um sistema de medição, erro de medição é definido pelo VIM como a diferença entre o valor medido e um valor de referência. A partir da comparação entre os dados da medição na calibração, gera-se um polinômio de ajuste que relaciona o valor indicado pelo instrumento 
submetido à calibração com o valor indicado pelo padrão. Definido o grau do polinômio de ajuste utilizado (aquele que produz a menor incerteza do ajuste), determina-se o erro de medição a partir da Equação (22):

$$
E_{i}=y\left(x_{i}\right)-y_{i}
$$

Nesta equação, $E$ denota o erro de medição; $y\left(x_{i}\right)$, o valor ajustado pelo polinômio de ajuste e $y_{i}$, o valor indicado pelo padrão.

\subsection{1 Calibração do subsistema contador de esfera (CONDE)}

Devido ao fato de o CONDE emitir pulsos de tensão, é possível medir a largura do pulso gerado, a partir do qual pode-se calcular a velocidade média de circulação de cada esfera que interrompe os feixes infravermelho. Esse dispositivo optoeletrônico de medição permite dois métodos de medição da velocidade da esfera: (i) pela largura do pulso gerado por cada esfera que interrompe o feixe ou (ii) pela razão entre a distância percorrida pela esfera entre duas unidades similares de CONDE, instaladas em justaposição e o tempo decorrido entre essa travessia (tempo esse medido com resolução de $0,5 \mu$ s pelo Controlador Lógico Programável, CLP).

O primeiro método de determinação da velocidade da esfera requer um CONDE simples. Importante entender que o diâmetro da esfera "percebido" pelo sensor (distância detectada desde a ativação do pulso eletrônico até sua desativação) é dado o nome de diâmetro efetivo $\phi_{\text {ef }}(\mathrm{mm})$. Determinado o diâmetro efetivo da esfera que cruza o feixe infravermelho, e medido o tempo de ativação do pulso causado pela passagem de uma esfera $\left(t_{\llcorner\mathrm{L}}\right)$, a velocidade do artefato de limpeza será dada pela razão $\phi_{e f} / t_{\llcorner p}$.

Já o segundo método requer a utilização de duas unidades independentes de CONDE (designado CONDE duplo, justapostos), assim permitindo, também, conseguir medir a velocidade da esfera. Na realidade, para corrigir a curvatura da esfera que atravessa o feixe infravermelho emitido pelo par optoeletrônico, a distância percorrida pela esfera não é simplesmente o espaçamento entre os planos de medição de cada CONDE, mas sim o que se denomina "distância efetiva" $d_{e f}$, definida pelo espaçamento percebido pelos circuitos optoeletrônicos, distância efetiva essa somente factível de ser determinada por meio de um processo de calibração. Um cronômetro no sistema de automação é disparado quando um pulso é emitido pelo primeiro CONDE. Quando é emitido um pulso pelo segundo CONDE, o cronômetro é parado e obtém-se o tempo total $t_{c r}$, 
definido pelo intervalo de tempo decorrido quando a esfera percorre a distância $d_{\text {eff }}$ Pela razão $d_{e f} / t_{c r}$ obtêm-se a velocidade média de circulação da esfera nesse espaço corrigido $d_{\text {ef. }}$ Considerando-se, entretanto, que o valor da velocidade da esfera que assegura eficácia do processo de limpeza é apenas indicativo (não se requer grande exatidão nessa medição), ambos os métodos são suficientes para atender a este objetivo. Já no que concerne ao principal objetivo do CONDE, que é o de contador do total de esferas circulantes pelo trocador (o que permite determinar se o total de esferas introduzidas no trocador de calor de fato retornaram), ambos os métodos são igualmente eficazes, já que a contagem das esferas se dá pelo processamento dos pulsos gerados e não pela sua largura.

O processo de calibração do dispositivo optoeletrônico desenvolvido para contar as esferas que circulam pelos tubos do trocador durante o processo de limpeza encontra-se descrito em relatório de um projeto de P\&D (Frota et al., 2018). No caso da versão 3 do dispositivo de limpeza de trocadores de calor, foi utilizado um CONDE duplo, ou seja, um dispositivo com redundância composto pela justaposição, no mesmo bloco do contador, de dois planos independentes de medição (Frota et al., 2018). Assim, para realizar a sua calibração, um procedimento experimental foi concebido para determinar o que se denomina de diâmetro efetivo $\left(D_{\text {ef }}\right)$ da esfera e distância efetiva percorrida pela esfera durante o intervalo de tempo em que atravessa o espaço entre os dois planos paralelos de medição $\left(L_{e f}\right)$ montados no CONDE duplo. Nesse contexto, diâmetro efetivo é o valor do diâmetro da esfera percebido pelos pares de sensores instalados em cada uma das placas eletrônicas do CONDE (planos de medição). Esse valor do diâmetro efetivo equivale à largura do pulso gerado pela esfera ao atravessar o primeiro plano de medição; ou seja, o pulso é ativado quando a esfera adentra no campo de ação do conjunto de sensores optoeletrônicos instalados em uma das placas eletrônicas e o pulso é desativado quando esta mesma esfera deixa o campo de ação do mesmo plano de medição. O diâmetro efetivo não necessariamente é igual ao diâmetro da esfera, já que esta, ao atravessar o campo de ação do feixe optoeletrônico, é afetada pelo que se denomina limiar de detecção que é explicado na seção a seguir.

\subsubsection{1}

\section{Caracterização do procedimento de calibração}

De forma esquemática, a Figura 44 ilustra uma esfera de diâmetro médio igual a $24,55 \mathrm{~mm}$ (valor indicado por um paquímetro com divisão de escala de $0,02 \mathrm{~mm}$ e esfera utilizada no trocador de calor de grande porte da usina Fontes 
Nova), utilizado em um procedimento de calibração para se determinar o diâmetro efetivo $\left(D_{\text {ef }}\right)$ (diâmetro aparente da esfera percebido pelo sistema optoeletrônico embarcado no CONDE duplo). Este é um valor que está diretamente associado à largura de pulso gerado pelo sistema optoeletrônico quando a esfera atravessa a zona sensível de influência dos pares de sensores optoeletrônicos instalados em cada um dos planos de medição. Na realidade, a Figura 44 ilustra momentos distintos da passagem de uma mesma esfera pelos planos de medição, mais precisamente:

- o momento em que a esfera (ilustrada na cor laranja) adentra o primeiro plano de medição, ativando o plano de medição \#1;

- após percorrer o canal interno do Conde duplo, a mesma esfera (que gerou o pulso ao cruzar o Plano de Medição \#1) percorre pelo interior do CONDE e adentra o Plano de Medição \#2, somente então permitindo ao sistema mensurar o espaçamento $\left(L_{e f}\right)$ entre os planos de medição pelo "tempo de voo" percebido pela eletrônica que controla os sistemas optoeletrônicos instalados nesses dois planos paralelos de medição;

- outros momentos de interesse são aqueles associados aos tempos subsequentes em que a esfera adentra e deixa cada um dos planos de medição. Momentos esses em que o circuito do sistema optoeletrônico gera os pulsos pela passagem da esfera por cada um dos planos de medição \#1 e \#2. Cada "largura de pulso" é uma indicação do diâmetro efetivo da esfera, independentemente percebido por cada plano de medição. Essas situações são representadas pela esfera ilustrada em linhas pontilhadas na mesma Figura 44. Esta figura ilustra, de forma esquemática, todas essas situações.

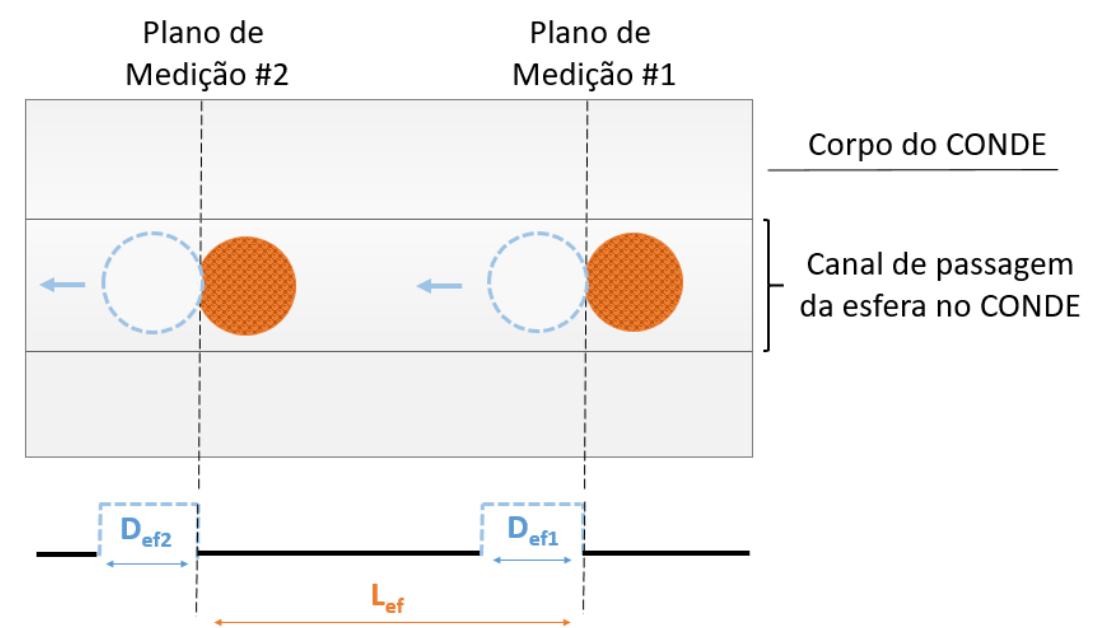

Figura 45 - Diâmetros efetivos e distância efetiva determinados pela passagem da esfera

Similarmente, a distância efetiva é definida pelo "espaçamento efetivo" entre dois planos de medição, ou seja, um comprimento percebido pelos sensores optoeletrônicos durante o "tempo de voo" da esfera, contabilizado no intervalo de tempo em que a esfera adentra o Plano de Medição \#1 e adentra o campo de ação Plano de Medição \#2, tal qual ilustrado na Figura 44. Esses conceitos de diâmetro 
efetivo e distância efetiva foram concebidos tendo em vista que eles, respectivamente, diferem do real valor do diâmetro da esfera e do espaçamento geométrico entre os Planos de Medição já que a curvatura da esfera, retarda a ativação e desativação do campo de ação dos sensores optoeletrônicos. Em outras palavras, a distância efetiva é a distância percebida pelo dispositivo optoeletrônico do Conde duplo (equipado com dois planos de medição) que corresponde ao tempo de voo da esfera entre esses planos de medição, ligeiramente inferior ao valor do espaçamento real entre esses planos de medição.

A Figura 46 ilustra o aparato experimental montado para se determinar o valor desses "comprimentos efetivos".

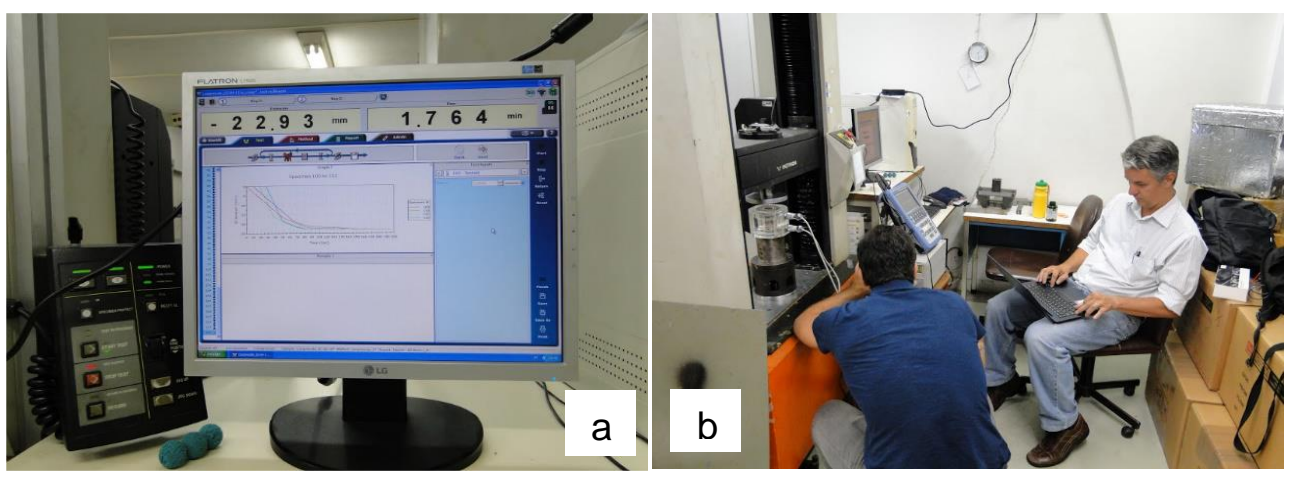

Figura 46 - Supervisório (a) montagem experimental (b) para determinação de $D_{\text {ef }}$ e Lef Fonte: (Frota et al., 2018)

No curso deste processo de calibração do CONDE duplo, foram realizadas repetidas medições da largura do pulso gerada pela passagem de uma esfera de diâmetro conhecido pela sua zona de medição (cilindro interno do CONDE exposto à ação dos feixes optoeletrônicos). Assim, o CONDE, apoiado em uma de suas faces paralela aos planos de medição (perpendicular ao eixo do cilindro interno por onde circula a esfera) foi montado na mesa estática de uma máquina de ensaios universal. A máquina de ensaios (INSTRON 5500R, classe de erro máximo de 0,5\%) disponível no Laboratório de Ensaios Mecânicos da PUC-Rio foi utilizada devido à sua capacidade de movimentar verticalmente seu travessão com baixa velocidade, gerando deslocamentos conhecidos com resolução do passo da rosca quadrada desse travessão. A Figura 46 ilustra imagens do acionador/computador de controle da máquina de ensaios, equipada com o seu sistema de automação e controle. A Figura 47 mostra o Conde montado no aparato experimental utilizado para sua calibração do diâmetro efetivo e da distância efetiva. 


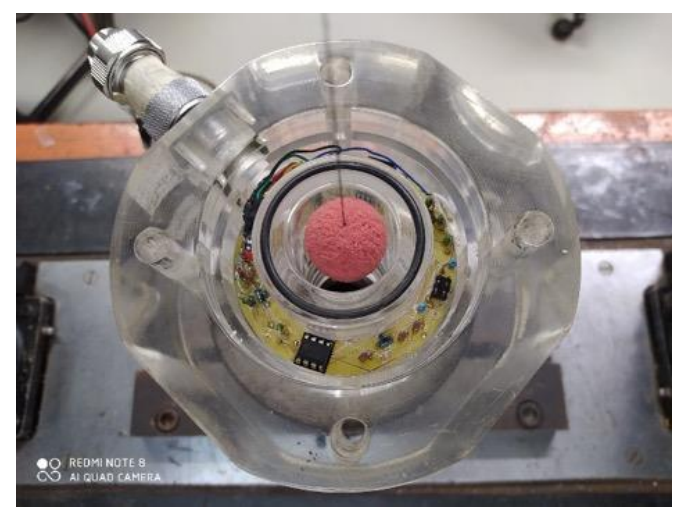

Figura 47 - CONDE duplo e esfera abrasiva utilizada no ensaio

Os pares de sensores emissores infravermelhos e receptores instalados na placa 1 (Plano de Medição \#1) formam o plano de ativação 1, identificados por:

- LTE-309 Lite-On EMITTER CLEAR (emissores);

- LTR-306 Lite-On Phototrans Trans (fototransistores).

Similarmente, os pares de sensores emissores infravermelhos e receptores instalados na placa 2 (Plano de Medição \#2) formam o plano de ativação 2 e são identificados pelos respectivos códigos do fabricante:

- Honeywell Photoemitter SEP8736 (emissores);

- Honeywell Phototransistor SDP8436 (fototransistores).

A máquina de ensaios universal INSTRON possui um sistema de controle eletrônico de deslocamento do seu travessão (que se move verticalmente com velocidades controladas da ordem de $\mathrm{mm} / \mathrm{min}$ e resolução de $0,01 \mathrm{~mm}$ ). Também integram o aparato experimental: (i) um osciloscópio portátil (Rohde \& Schwarz, digital, Modelo RTH 1002, 5 GSa/s), mostrado na Figura 55, utilizado para visualizar e medir os pulsos gerados sempre que uma esfera cruza os feixes optoeletrônico; (ii) uma fonte de alimentação (ICEL, Modelo PS 6000), que alimenta o (iii) circuito do CONDE duplo, que opera com tensões de $5 \mathrm{~V}$ e $24 \mathrm{~V}$.

A Figura 48 apresenta os instrumentos eletrônicos utilizados para montar o aparato experimental da calibração do CONDE duplo.

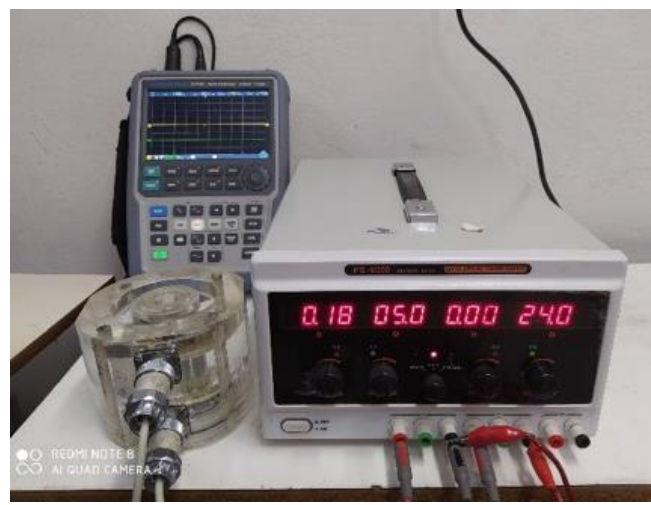

Figura 48 - Aparato experimental utilizado (osciloscópio, fonte de tensão e CONDE) 
Conforme mostrado na Figura 49, a esfera foi conectada ao travessão da máquina de ensaio por um fio inextensível, assim assegurando a perpendicularidade do seu movimento descendente enquanto penetra no cilindro interno do CONDE, movendo-se perpendicularmente aos planos de medição.

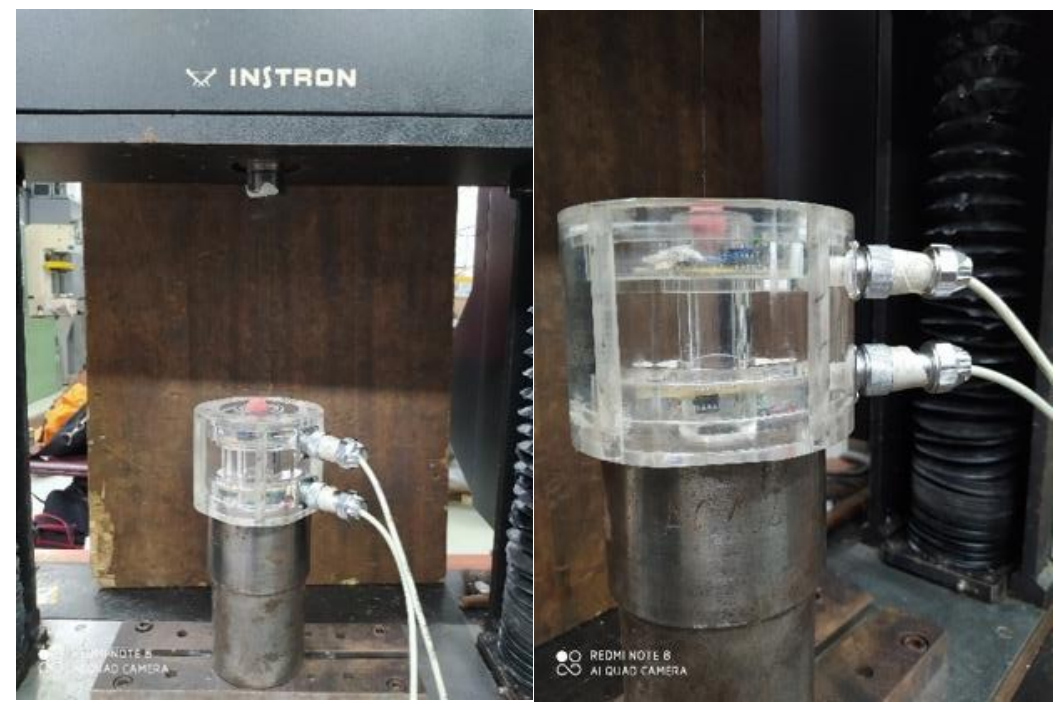

Figura 49 - Montagem concebida para forçar a esfera a interromper o feixe óptico

Assim movimentando-se, a esfera ativa e desativa os sensores optoeletrônicos sempre que entra ou sai do seu campo de ação.

Em outras palavras, este arranjo experimental (convenientemente instalado na máquina de ensaios universal) consegue realizar movimentos incrementais precisos e controlados na direção vertical, comandados pelo travessão da máquina de ensaios, movimentos esses monitorados pelos sensores optoeletrônicos. Operar na vizinhança dessa zona de ativação eletrônica (monitorado pelo osciloscópio, conectado aos terminais dos sensores do contador) permite, de forma prática, determinar com resolução de $0,01 \mathrm{~mm}$, a posição em que a esfera se encontra na iminência de acionar ou desativar um pulso. Em outras palavras, poder-se-ia dizer que, dada a sua geometria, a esfera, ao adentrar na zona de ativação, não gera, de imediato, um pulso completo, mas, sim, um sinal característico que se denomina "limiar de ativação", tal qual mostrado pela imagem da tela do osciloscópio, ilustrada na Figura 50, a seguir. 


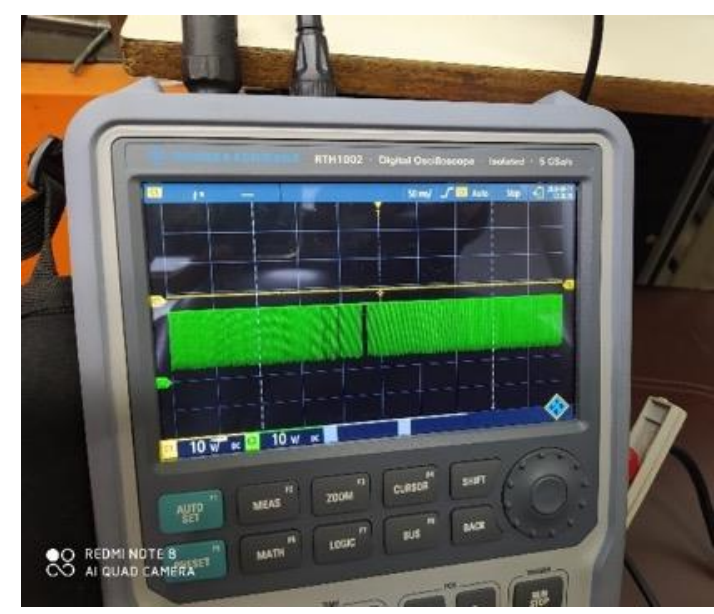

Figura 50 - Limiar de ativação dos sensores optoeletrônicos

Nessa posição, a esfera (na iminência de interromper os feixes optoeletrônicos dos sensores) posiciona-se na vizinhança da cota zero, que caracteriza o início da zona de limiar de ativação. Pequenas variações da posição da esfera (da ordem de centésimo de $\mathrm{mm}$ ), para cima ou para baixo, produzem alterações nesse sinal do limiar de detecção.

Como dito, a esfera, ao adentrar na zona de ativação não aciona, de imediato, o sistema optoeletrônico. Com isso, embora uma parte da esfera já tenha cruzado a zona de ativação, essa parte não gera o início do pulso, ou seja, não é "percebida" pelos sensores. Deslocando a esfera um pouco mais, o pulso começa a ser gerado e, então, a esfera é percebida pelos sensores que compõem o plano de ativação. Deslocando o travessão de modo a permitir que todo o diâmetro da esfera cruze o plano de ativação de um dos Planos de Medição, em determinado momento, a mesma situação de limiar de ativação se apresenta novamente. A distância correspondente à largura do pulso gerado pela passagem da esfera pela zona de limiar de ativação por um dos planos de medição é denominada "Diâmetro efetivo". Como o CONDE duplo possui redundância, já que possui dois planos de medição independentes e paralelamente instalados, para cada esfera que cruza os planos de medição, o valor do Diâmetro efetivo é repetido, fornecendo dois valores: $D_{\text {ef1 }}$ e $D_{\text {ef2. }}$. Embora próximos, esses valores podem diferir em função de pequenos desvios de alinhamento na montagem dos sensores optoeletrônicos e características individuais dos sensores em cada um dos circuitos impressos instalados nos planos de medição.

O monitoramento da zona de limiar permite, então, ao operador do experimento, encontrar a cota zero, simplesmente movimentando o travessão da INSTRON em pequenos incrementos até que a zona de limiar apareça.

A Figura 51 ilustra a condição de zero optoeletrônico identificado. 


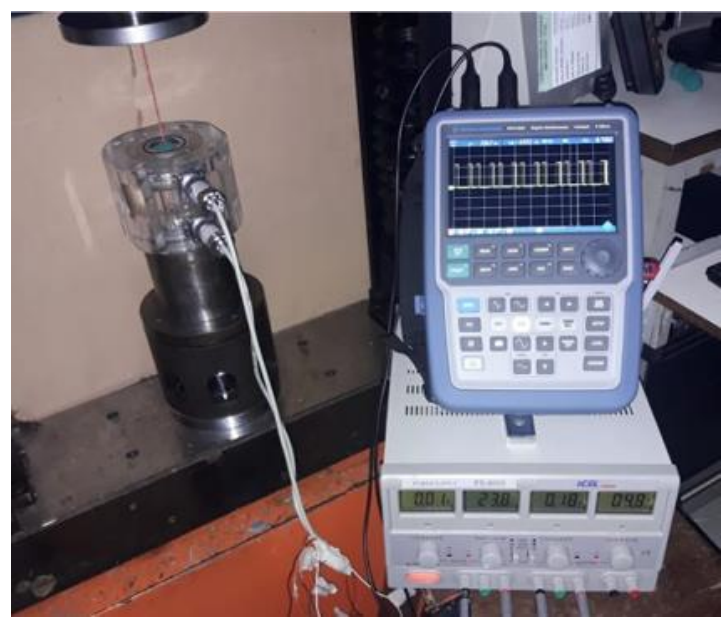

Figura 51 - Identificação do zero "optoeletrônico"

Fonte: Relatório Técnico no: 13/2018 (Frota, 2018)

Para facilitar a compreensão e evitar equívocos com a referência dos dados, as placas eletrônicas são identificadas com a gravação "Placa 1"e "Placa 2". A Figura 52 ilustra a passagem da esfera pelos planos de ativação dos sensores que geram os diâmetros efetivos $D_{\text {ef1 }}$ e $D_{\text {ef2. }}$.

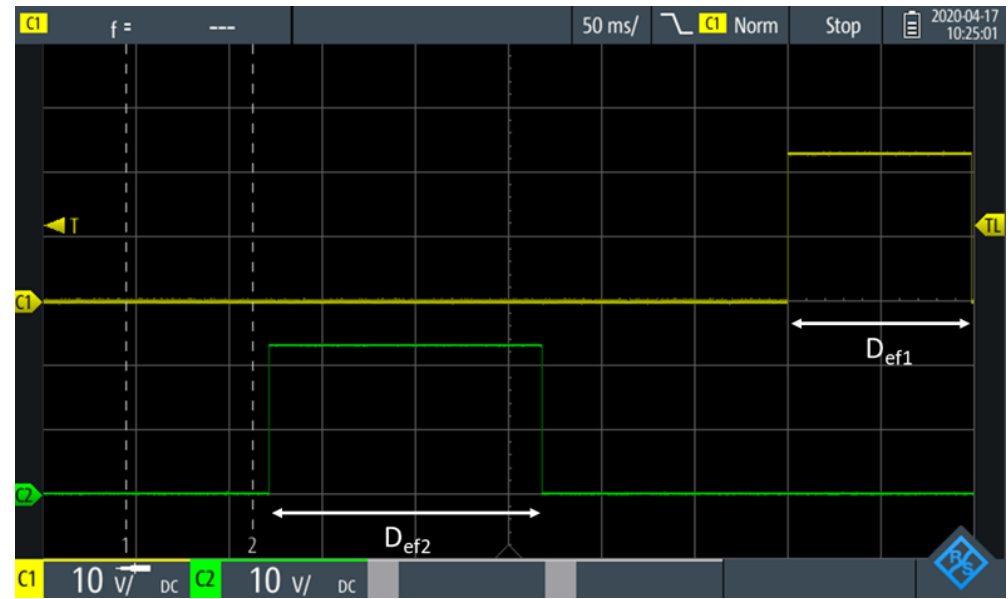

Figura 52 - Pulsos gerados pelos planos dos sensores ( $D_{\text {ef1 }}$ e $\left.D_{\text {ef2 }}\right)$

\subsubsection{2}

\section{Resultados da calibração dos parâmetros efetivos}

Os valores $D_{\text {ef1 }}$ e $D_{\text {ef2 }}$ obtidos por meio do ensaio que se utiliza do deslocamento do travessão da máquina de ensaios universal INSTRON estão, respectivamente, mostrados nas Tabelas 25 e 26 do Apêndice $B$.

A Tabela 7, a seguir, apresenta o diâmetro da esfera (medido por um paquímetro calibrado), esfera essa utilizada no ensaio de calibração realizado na máquina universal de ensaios INSTRON para determinação de $D_{\text {ef1 }}$ e $D_{\text {ef2. }}$. Para cada Plano de Medição, são mostrados o valor médio (e respectivo desvio padrão) das medições realizadas pelo procedimento de calibração dos dispositivos optoeletrônicos embarcados no CONDE duplo. 
Tabela 7 - Procedimento de calibração para determinação de $D_{\text {ef1 }}$ e $D_{\text {ef2 }}$

\begin{tabular}{|c|c|c|c|c|c|c|}
\hline De (diâmetro de & \multicolumn{3}{|c|}{ Diâmetro Efetivo $D_{\text {ef1 }}$} & \multicolumn{3}{|c|}{ Diâmetro Efetivo $D_{\text {ef2 }}$} \\
\hline $\begin{array}{l}\text { Diâmetro médio } \\
(\mathrm{mm})\end{array}$ & $\begin{array}{l}\text { Valor médio } \\
\text { (mm) }\end{array}$ & $\begin{array}{l}\text { Desv Pad } \\
(\mathrm{mm})\end{array}$ & $\begin{array}{l}\text { Dif } \\
(\%)\end{array}$ & $\begin{array}{l}\text { Valor médio } \\
(\mathrm{mm})\end{array}$ & $\begin{array}{l}\text { Desv Pad } \\
(\mathrm{mm})\end{array}$ & $\begin{array}{l}\text { Dif } \\
(\%)\end{array}$ \\
\hline 24,55 & 22,45 & 0,0142 & $9,4 \%$ & 22,60 & 0,0206 & $8,6 \%$ \\
\hline
\end{tabular}

Conforme mostrado, o impacto do sistema optoeletrônico na detecção da esfera não é desprezível, a largura do pulso (proporcional ao diâmetro da esfera) que é gerado pela passagem da esfera é inferior a $10 \%$ (9,4 \% quando detectado pelo Plano de Medição 1 e 8,6 \%, quando detectado pelo plano de medição 2). Ou seja, para o sistema optoeletrônico construído, o diâmetro efetivo é cerca de 10 \% inferior ao diâmetro real da esfera que gera o pulso, valor esse que, se não for devidamente corrigido, refletirá em um erro sistemático no sistema de medição.

A incerteza associada ao deslocamento vertical da esfera durante o procedimento de calibração ( $\boldsymbol{u}_{\text {inst }}$ ) é dada pela resolução de deslocamento da máquina de ensaio INSTRON, pois os pares dos sensores ópticos não possuem uma resolução específica de comprimento, visto que apenas emitem ou não um pulso eletrônico quando ativados. $O$ valor de incerteza associada à repetibilidade é calculada pela Equação (9). Os valores das incertezas associadas ao instrumento e à repetibilidade, são, a seguir, apresentados:

$$
\begin{array}{lll}
u_{\text {inst }} \mathrm{D}_{\text {ef1 }}=0,0029 \mathrm{~mm} & \text { e } & u_{r} \mathrm{D}_{\text {ef1 }}=0,0026 \mathrm{~mm} \\
u_{\text {inst }} \mathrm{D}_{\text {ef } 2}=0,0029 \mathrm{~mm} & \text { e } & u_{r} \mathrm{D}_{\text {ef } 2}=0,0038 \mathrm{~mm}
\end{array}
$$

Calculado a partir do valor $t$-Student, para um nível de confiança de 95,0 \%, e para as condições experimentais apresentadas $(\mathrm{N}=30)$, o fator de abrangência $k$ foi determinado; i.e.: $k=2,05$.

Os cálculos da análise das incertezas expandidas associadas às medições, calculadas pela Equação (7), produziram, respectivamente, os seguintes valores de incerteza associada ao diâmetro efetivo, com confiabilidade de 95,0 \%:

$$
\begin{aligned}
U D_{\text {ef1 }} & =0,0079 \mathrm{~mm} \\
U D_{\text {ef } 2} & =0,0097 \mathrm{~mm}
\end{aligned}
$$

Utilizando o mesmo experimento, foi medida a distância efetiva $L_{\text {ef }}$ (espaçamento efetivo entre os planos paralelos de medição que contêm os dois circuitos eletrônicos nas placas circulares). Esta é a distância efetiva $L_{\text {ef }}$ que corresponde à distância entre a ativação dos pares de sensores ópticos de uma placa (plano de ativação) e a ativação dos sensores da outra placa (próximo plano de ativação). A Figura 53 ilustra a passagem da esfera pelos planos de ativação, permitindo visualizar a distância efetiva, pelo procedimento de calibração. 


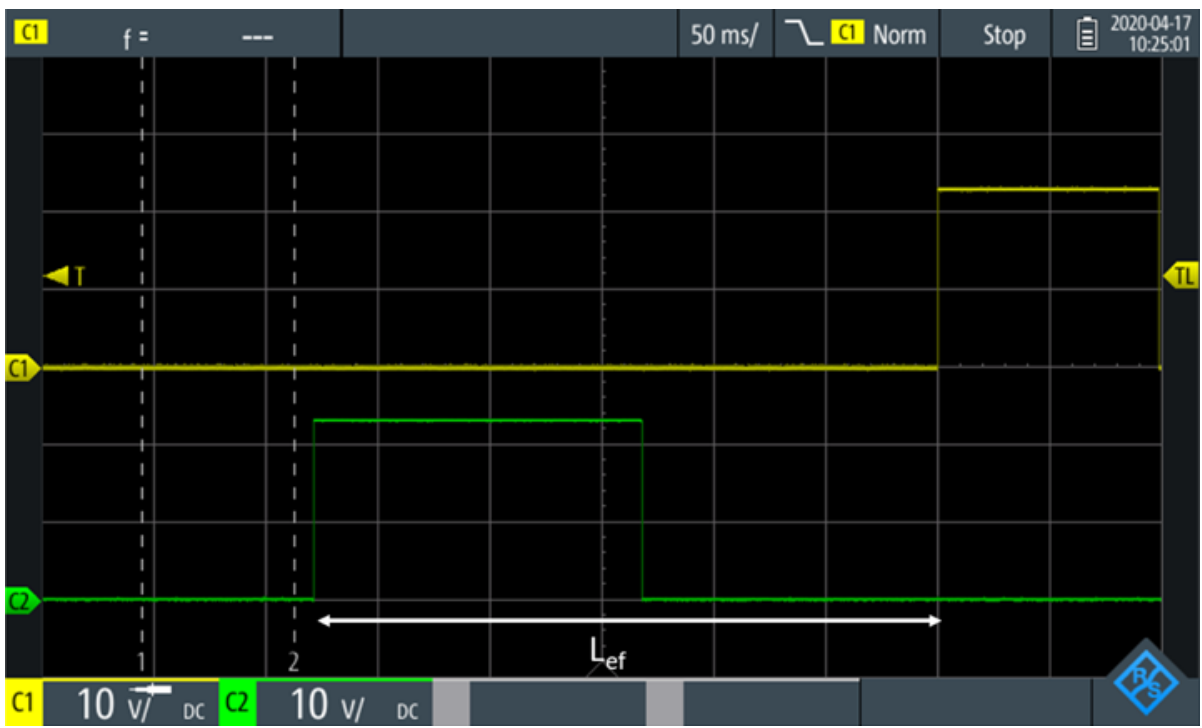

Figura 53 - Pulsos gerados pelos planos das placas (Lef)

A Tabela 27 do Apêndice B apresenta a totalidade dos valores obtidos na medição de $L_{\text {ef }}$ por meio do ensaio realizado, de maneira semelhante ao que foi utilizado para determinar os valores dos diâmetros efetivos $D_{\text {ef1 }}$ e $D_{\text {ef2. }}$.

O valor da média e desvio padrão associados à distância efetiva $L_{\text {ef, }}$ são, a seguir, apresentados:

$$
\text { média } \mathrm{L}_{\mathrm{ef}}=49,28 \mathrm{~mm} \text { e Desv Pad } \mathrm{L}_{\mathrm{ef}}=0,00 \mathrm{~mm}
$$

Nota-se que o valor do desvio padrão é igual a 0,00 o que caracteriza a excelente repetibilidade do experimento. Isso ocorre devido ao fato de todos os valores indicados nas medições de $L_{\text {ef }}$ serem iguais, como mostrado na Tabela 3 do Apêndice B. Embora seja uma condição muito rara, ela também foi obtida previamente em ensaios anteriores utilizando o mesmo aparato experimental.

O cálculo da análise da incerteza expandida associada à medição, apresentado na Equação (7), realizada para obter a distância efetiva, com confiabilidade de 95,0\%, é:

$$
U \mathrm{~L}_{\mathrm{EF}}=0,0059 \mathrm{~mm}
$$

Analisando os valores de $D_{\text {ef1 }}, D_{\text {ef2 }}$ e $L_{e f}$, é visto que a incerteza é da ordem de $10^{-4}$ milésimos de metro. Durante a operação do SIREA 3, a velocidade da esfera é calcula na unidade metro por segundo. Com isso, pode-se afirmar que as incertezas encontradas estão dentro do limite de tolerância admitido no projeto construtivo do CONDE duplo.

Uma vez calculadas as incertezas expandidas associadas aos diâmetros efetivos ( $D_{\text {ef1 }}$ e $D_{\text {ef2 }}$ ), e ao espaçamento entre os planos de medição ( $L_{\text {ef }}$ ), é possível relatar o valor final desses parâmetros, determinados com base no procedimento de calibração, cujos resultados finais, acrescidos de suas 
respectivas incertezas, são a seguir apresentados, para um intervalo de confiança de $95,0 \%$ (fator de abrangência $k=2,05$ ). A Tabela 8 , a seguir, resume os resultados das calibrações dos diâmetros efetivos e espaçamento efetivo com suas respectivas incertezas.

Tabela 8 - Resultados de Diâmetros Efetivos e Espaçamento Efetivo

\begin{tabular}{c|c|c}
\hline Diâmetro Efetivo $\mathbf{D}_{\mathbf{e f} 1}$ & Diâmetro Efetivo $\mathbf{D}_{\mathbf{e f} \mathbf{2}}$ & Espaçamento Efetivo $\mathbf{L}_{\mathbf{e f}}$ \\
$\mathrm{D}_{\mathrm{ef} 1}=22,45 \pm 0,0099 \mathrm{~mm}$ & $\mathrm{D}_{\mathrm{ef} 2}=22,60 \pm 0,0097 \mathrm{~mm}$ & $\mathrm{~L}_{\mathrm{ef}}=49,28 \pm 0,0059 \mathrm{~mm}$ \\
\hline
\end{tabular}

Conforme mostrado na Tabela 8 , a medição de $L_{\text {ef, }}$ - espaço entre as ativações dos Planos de Medições - apresenta um valor de incerteza menor que aquela associada à largura de pulso, muito provavelmente por independer do tamanho da esfera que atravessa os feixes optoeletrônicos do CONDE duplo. Conforme ilustrado na Figura 60, o "espaçamento efetivo" é determinado sem a necessidade de medir as larguras de pulsos percebidas por cada um dos planos de medição, mas sim, o instante que a esfera adentra em cada um desses planos. Outro fato é que a medição do diâmetro efetivo, como já descrito, é realizada conforme a percepção dos sensores optoeletrônicos à passagem da esfera. Isso significa que o mesmo grupo de sensores é responsável pela ativação e desativação do pulso acumulando assim a incerteza inerente aos sensores presentes no Plano de medição. O valor do "espaçamento efetivo" determinado pelo procedimento de calibração descrito (documentado na Tabela 8) é o valor que deve ser utilizado no software do sistema de automação para se calcular a velocidade da esfera que circula pelo CONDE duplo.

\subsection{2}

\section{Calibração do subsistema de medição de vazão}

Como descrito na seção 4.2.1, o CONDE duplo oferece dois modos complementares de operação. Desempenha a sua função primária de dispositivo de limpeza de trocadores de calor, por conveniência equipado com um contador de esferas (que permite, também, pela largura de pulso gerado, medir a velocidade de circulação da esfera e, por seguinte, medir a vazão do fluido de trabalho que transporta a esfera). Entretanto, o CONDE teve que passar por um reparo e, quando ficou pronto, não pôde ser instalado no sistema de limpeza para calibração da sua função de medir a velocidade das esferas devido à pandemia.

Adicionalmente à sua função principal de atuar como dispositivo de limpeza de trocadores de calor, a nova versão do SIREA 3 foi adaptada para operar como um calibrador automatizado de instrumentos de pressão e vazão. A seção, a seguir, descreve o procedimento de calibração de dois medidores de vazão (do 
tipo ultrassônico e outro do tipo magnético) por meio do medidor padrão de vazão magnético Endress Hauser com rastreabilidade em um laboratório acreditado, conforme Certificado de Calibração incluído no Anexo A. Os dispositivos CONDE e Endress Hauser integram a função primordial do SIREA 3 e são permanentes no sistema de limpeza. Nesta calibração o medidor magnético Endress Hauser é utilizado como medidor padrão.

\subsubsection{1}

\section{Caracterização dos medidores de vazão}

A seguir, descrevem-se as características técnicas e metrológicas, de interesse, do medidor de vazão padrão, instalado no SIREA 3, utilizado para a calibração dos medidores de vazão e CONDE Duplo:

- Padrão: Medidor magnético (Fabricante Endress Hauser; Modelo Promag D 400 2"; número de série: PA021392000);

- Resolução: $0,001 \mathrm{~m}^{3} / \mathrm{h}$.

A Figura 54 apresenta o medidor de vazão magnético Endress Hauser utilizado como instrumento padrão.

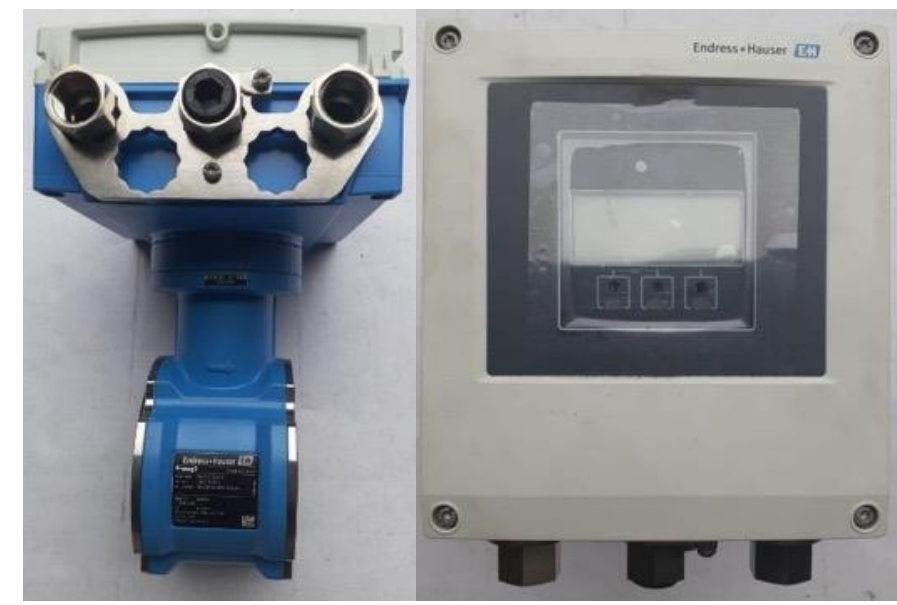

Figura 54 - Medidor de vazão magnético Endress Hauser

A seguir, descrevem-se as características técnicas e metrológicas, de interesse, dos medidores de vazão calibrados:

- Medidor magnético (Fabricante IFM; Modelo SM9000; número de série: IFM/SN);

- Resolução: 0,02 m³/h;

- Medidor ultrassônico (Fabricante Vertus; Modelo TUSM-100; número de série: TM00012887);

- Resolução: $0,01 \mathrm{~m}^{3} / \mathrm{h}$.

A Figura 55 apresenta os medidores (magnético e ultrassônico, respectivamente). 


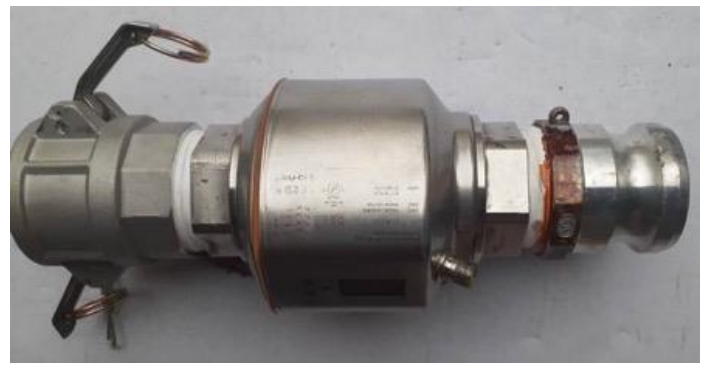

A

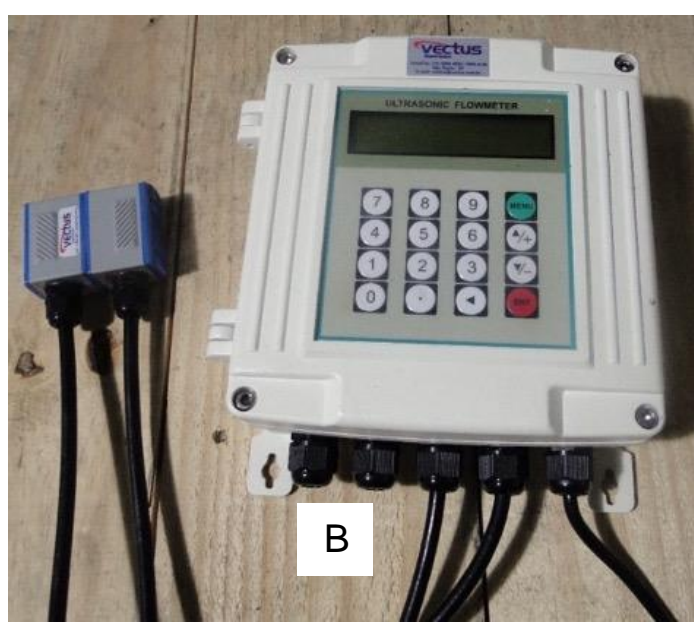

Figura 55 - Medidor de vazão magnético (A) e ultrassônico (B)

\subsubsection{2}

\section{Procedimento automatizado para calibração de medidores de vazão}

A calibração dos medidores de vazão (IFM e Vectus) é realizada com o auxílio de um sistema de aquisição de réplicas que permite que a calibração seja realizada com um número grande de valores de medição, o que contribui para a redução da incerteza do tipo $A$ associada às medições por comparação contra um instrumento padrão de referência.

Com o propósito de assegurar a confiabilidade metrológica da calibração, cuidados devem ser tomados. Dentre esses, respeitar os comprimentos mínimos recomendados pela norma aplicável (ISO 6817), que estabelece comprimentos mínimos equivalentes a 10 diâmetros a montante e 5 diâmetros a jusante do medidor submetido à calibração e do medidor utilizado como padrão de referência. Esses comprimentos mínimos asseguram a condição de "escoamento completamente desenvolvido" 5 na região onde o medidor objeto da calibração será instalado; A Figura 56 ilustra o aparato experimental montado para a calibração do subsistema de vazão e a montagem do aparato experimental utilizado, adotando todos os critérios para garantir o escoamento totalmente desenvolvido e instalação de todos os medidores de vazão em série (acoplados, um após o outro), garantindo assim que todos sejam expostos à mesma vazão.

${ }^{5}$ Escoamento totalmente desenvolvido é aquele onde em que o perfil de velocidade não varia ao longo do eixo do tubo (Fox et al., 2016). 


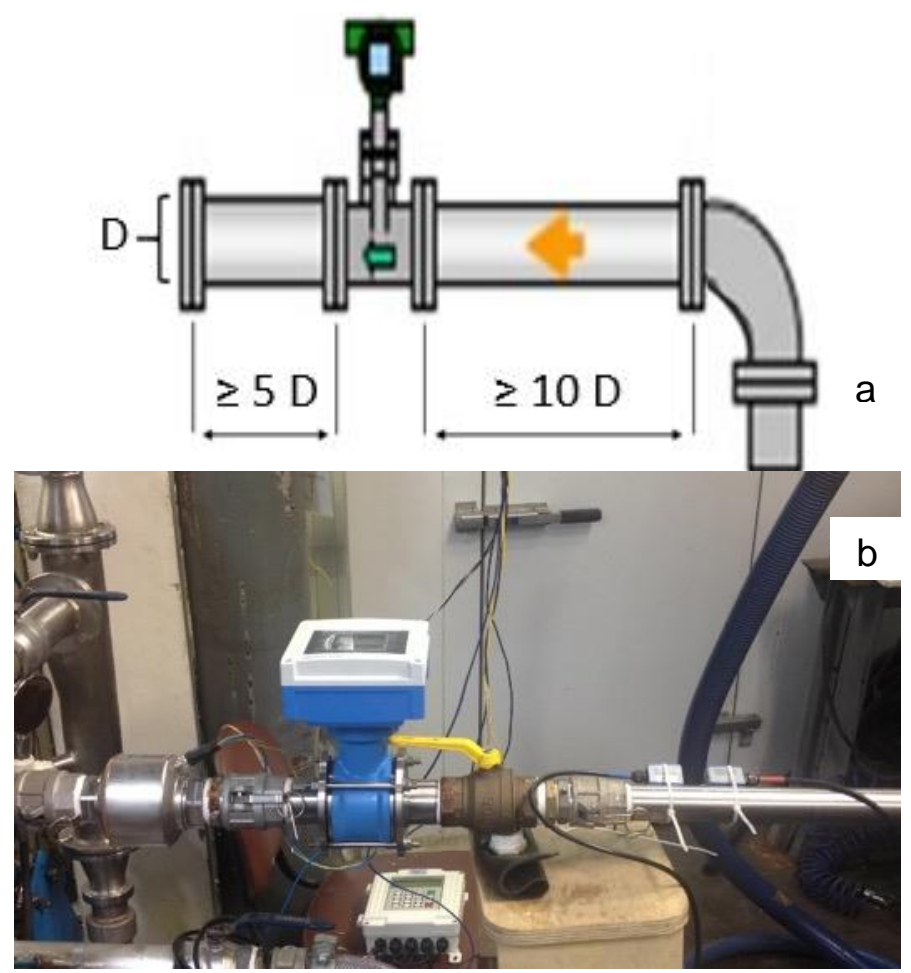

Figura 56 - Critérios para posicionamento do medidor de vazão (a) e aparato experimental (b)

O aumento de dados de uma determinada medição de vazão é obtida com o auxílio do sistema de aquisição de dados (FieldLogger, modelo 8812191900 do fabricante Novus), na frequência de $1 \mathrm{~Hz}$ (aquisição de 1 dado a cada segundo), assim viabilizando, simultaneamente, a coleta independente de dados de cada um dos três medidores de vazão. A Figura 57 ilustra o sistema de aquisição em funcionamento, i.e., armazenando os valores de vazão gerados pelos medidores.

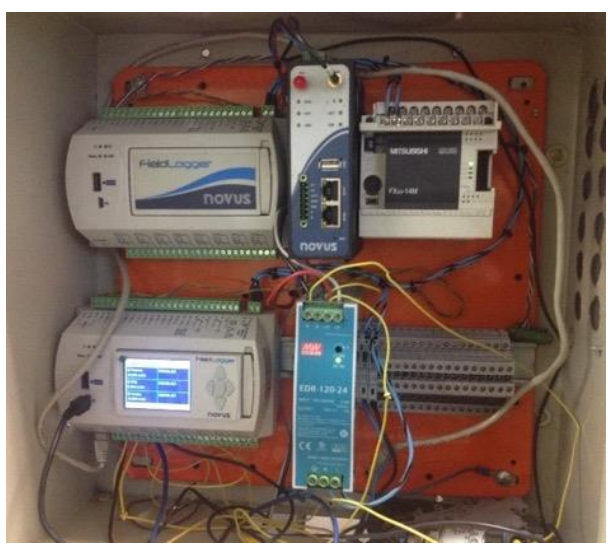

Figura 57 - Sistema de aquisição de dados

Após a instalação e configuração dos equipamentos utilizados na calibração dos medidores de vazão, é acionado o grupo motor bomba hidráulica, que mantém o escoamento constante na frequência pré-determinada de operação do sistema hidráulico. Para se conseguir diferentes condições de calibração, a vazão dada pela bomba pode ser alterada variando-se a frequência do inversor acoplado ao 
motor da bomba. Usualmente, a calibração é realizada nas frequências de $60 \mathrm{~Hz}$, $55 \mathrm{~Hz}, 50 \mathrm{~Hz}, 45 \mathrm{~Hz}, 40 \mathrm{~Hz}, 35 \mathrm{~Hz}$ e $30 \mathrm{~Hz}$, oferecendo 7 condições de vazão.

Cada frequência selecionada de operação do grupo motor bomba corresponde a uma determinada rotação do rotor da bomba hidráulica que alimenta o SIREA 3. Essas rotações são 3535 rpm (60 Hz), 3235 rpm (55 Hz), 2935 rpm (50 Hz), 2635 rpm (45 Hz), 2335 rpm (40 Hz), 2035 rpm (35 Hz) e 1735 (30 Hz) rpm. Os dados de medição em cada rotação selecionada são coletados ao longo de 20 minutos, de maneira ininterrupta, gerando cerca de 1200 réplicas da medição de vazão para cada condição imposta do escoamento. Concluída a coleta de dados, esses são avaliados pelo critério de Chauvenet para identificação e eliminação de eventuais valores considerados outliers. Os dados de calibração para cada valor da rotação da bomba encontram-se documentados nas Tabela 28-34 do Apêndice C.

Este método de calibração foi utilizado para minimizar ao máximo a incerteza associada à repetibilidade (incerteza do Tipo A), considerado o maior componente de incerteza devido à natureza física do escoamento (turbulento). Não obstante o inversor de frequência assegurar rotação praticamente constante do rotor da bomba hidráulica, o grande número de réplicas minimiza o efeito de uma eventual variação da rotação da bomba, o que impactaria na estabilidade da vazão de água no tubo onde se encontram instalados os medidores.

\subsubsection{3 Resultados da calibração dos medidores de vazão}

A determinação da incerteza associada à medição de vazão pelos medidores submetidos à calibração é realizada com base nos procedimentos apresentados na seção 4.1 , que descreve os procedimentos necessários para a calibração de um instrumento de medição.

Os valores de médias e desvios padrão das réplicas da medição de vazão, para cada condição de escoamento imposto pela rotação do rotor da bomba, são documentados na Tabela 9, a seguir: 
Tabela 9 - Valores de média e desvio padrão da calibração de vazão

\begin{tabular}{c|ccc|c|c|c|}
\hline Frequência & \multicolumn{3}{|c|}{ Média $\left(\mathrm{m}^{3} / \mathrm{h}\right)$} & \multicolumn{3}{c}{ Desvio Padrão $\left(\mathrm{m}^{3} / \mathrm{h}\right)$} \\
selecionada $(\mathrm{Hz})$ & Padrão & IFM & Vectus & Padrão & IFM & Vectus \\
30 & 5,605 & 5,62 & 6,49 & 0,008 & 0,008 & 0,078 \\
35 & 7,088 & 7,09 & 6,68 & 0,015 & 0,017 & 0,051 \\
40 & 9,628 & 9,62 & 9,82 & 0,098 & 0,100 & 0,527 \\
45 & 10,792 & 10,80 & 11,87 & 0,079 & 0,078 & 0,765 \\
50 & 12,071 & 12,08 & 12,71 & 0,049 & 0,046 & 0,491 \\
55 & 12,123 & 12,13 & 12,61 & 0,064 & 0,067 & 0,515 \\
60 & 13,053 & 13,06 & 13,39 & 0,099 & 0,100 & 0,436 \\
\hline
\end{tabular}

Calculado a partir do valor $t$-Student, para um nível de confiança de 95,0 \%, com as condições experimentais apresentadas ( $N>=1200)$, o fator de abrangência calculado é $k=1,96$. Determinados os componentes de incerteza associados à resolução do instrumento, ao padrão e à repetibilidade, é possível calcular a incerteza expandida associada às medições realizadas pelos medidores de vazão. O resultado da incerteza expandida associada à calibração de cada medidor de vazão, calculado pela Equação (7), com confiabilidade de 95,0 \%, são apresentados na Tabela 10:

\begin{tabular}{|c|c|c|c|}
\hline \multirow[t]{2}{*}{$\begin{array}{c}\text { Frequência } \\
\text { selecionada }(\mathrm{Hz})\end{array}$} & \multicolumn{3}{|c|}{$\begin{array}{c}\text { Incerteza expandida }(k=1,96) \\
\left(\mathrm{m}^{3} / \mathrm{h}\right)\end{array}$} \\
\hline & Padrão & IFM & Vectus \\
\hline 30 & 0,016 & 0,02 & 0,02 \\
\hline 35 & 0,016 & 0,02 & 0,02 \\
\hline 40 & 0,035 & 0,04 & 0,04 \\
\hline 45 & 0,035 & 0,04 & 0,05 \\
\hline 50 & 0,035 & 0,04 & 0,04 \\
\hline 55 & 0,035 & 0,04 & 0,04 \\
\hline 60 & 0,035 & 0,04 & 0,04 \\
\hline
\end{tabular}

\subsubsection{4}

\section{Comparação entre os métodos de calibração de vazão}

Para evidenciar o benefício do método adotado para a calibração dos medidores de vazão, a Tabela 11 apresenta o erro das médias (valor da média do instrumento calibrado subtraído do valor da média indicada pelo instrumento padrão). Os valores médios são obtidos utilizando-se o método que faz uso de um grande número de réplicas da mesma medição obtida pelo sistema de aquisição de dados (FieldLogger), enquanto o método tradicional é aquele que utiliza apenas 3 leituras do indicador do instrumento calibrado, que são comparadas com o valor de referência indicado pelo instrumento padrão. Os resultados obtidos por esses 
dois métodos são apresentados na Tabela 11, que evidencia a vantagem do método automatizado via FieldLogger.

Tabela 11 - Erro das médias do medidor IFM com o uso do FieldLogger e método tradicional

\begin{tabular}{|c|c|c|c|c|c|}
\hline \multirow[b]{2}{*}{$\begin{array}{c}\text { Frequência } \\
\text { selecionada } \\
(\mathrm{Hz})\end{array}$} & \multicolumn{5}{|c|}{ Erro da média em relação ao instrumento padrão } \\
\hline & $\begin{array}{c}\text { Média do } \\
\text { Padrão } \\
\left(\mathrm{m}^{3} / \mathrm{h}\right)\end{array}$ & $\begin{array}{c}\text { Média IFM } \\
\text { (FieldLogger) } \\
\left(\mathrm{m}^{3} / \mathrm{h}\right)\end{array}$ & $\begin{array}{c}\text { Média IFM } \\
\text { (tradicional) } \\
\left(\mathrm{m}^{3} / \mathrm{h}\right)\end{array}$ & $\begin{array}{c}\text { Erro da média } \\
\text { IFM } \\
\text { (FieldLogger) } \\
\left(\mathrm{m}^{3} / \mathrm{h}\right)\end{array}$ & $\begin{array}{c}\text { Erro da média } \\
\text { IFM } \\
\text { (tradicional) } \\
\left(\mathrm{m}^{3} / \mathrm{h}\right)\end{array}$ \\
\hline 30 & 5,605 & 5,62 & - & 0,02 & - \\
\hline 35 & 7,088 & 7,09 & - & 0,00 & - \\
\hline 40 & 9,628 & 9,62 & 10,08 & $-0,01$ & 0,45 \\
\hline 45 & 10,792 & 10,80 & 11,36 & 0,01 & 0,57 \\
\hline 50 & 12,071 & 12,08 & 12,62 & 0,01 & 0,55 \\
\hline 55 & 12,123 & 12,13 & 13,94 & 0,01 & 1,82 \\
\hline 60 & 13,053 & 13,06 & 14,18 & 0,00 & 1,13 \\
\hline
\end{tabular}

A Tabela 12 apresenta a relação percentual do erro das médias dos valores de medição obtidos por meio do sistema de aquisição de dados e do procedimento tradicional de calibração pela média dos valores do medidor padrão (erro / média do padrão x 100).

Tabela 12 - Erro percentual em relação à média do medidor padrão

\begin{tabular}{c|c|c|c}
\hline & \multicolumn{2}{|c}{} \\
$\begin{array}{c}\text { Frequência } \\
\text { selecionada }\end{array}$ & \multicolumn{2}{|c}{ Erros percentuais das médias IFM em relação ao medidor padrão } \\
& Média do Padrão & $\begin{array}{c}\text { Erro média IFM } \\
\text { (FieldLogger) }\end{array}$ & $\begin{array}{c}\text { Erro média IFM } \\
\text { (tradicional) }\end{array}$ \\
& & & \\
$(\mathrm{Hz})$ & $\left(\mathrm{m}^{3} / \mathrm{h}\right)$ & $(\%)$ & - \\
30 & 5,605 & 0,36 & - \\
35 & 7,088 & 0,00 & 4,68 \\
40 & 9,628 & $-0,10$ & 5,28 \\
45 & 10,792 & 0,09 & 4,55 \\
50 & 12,071 & 0,08 & 15,00 \\
55 & 12,123 & 0,08 & 8,65 \\
60 & 13,053 & 0,00 & - \\
\hline
\end{tabular}

Conforme documentado pelos resultados apresentados na Tabela 12, a automação da calibração, que aumenta consideravelmente o número de réplicas de uma mesma medição, melhora de forma expressiva a confiabilidade metrológica da calibração.

A Figura 58 apresenta as médias dos valores obtidos pelos métodos apresentados (via calibração com aquisição de dados e via calibração tradicional), incluindo a barra do erro documentado na Tabela 12 para cada condição da calibração. 


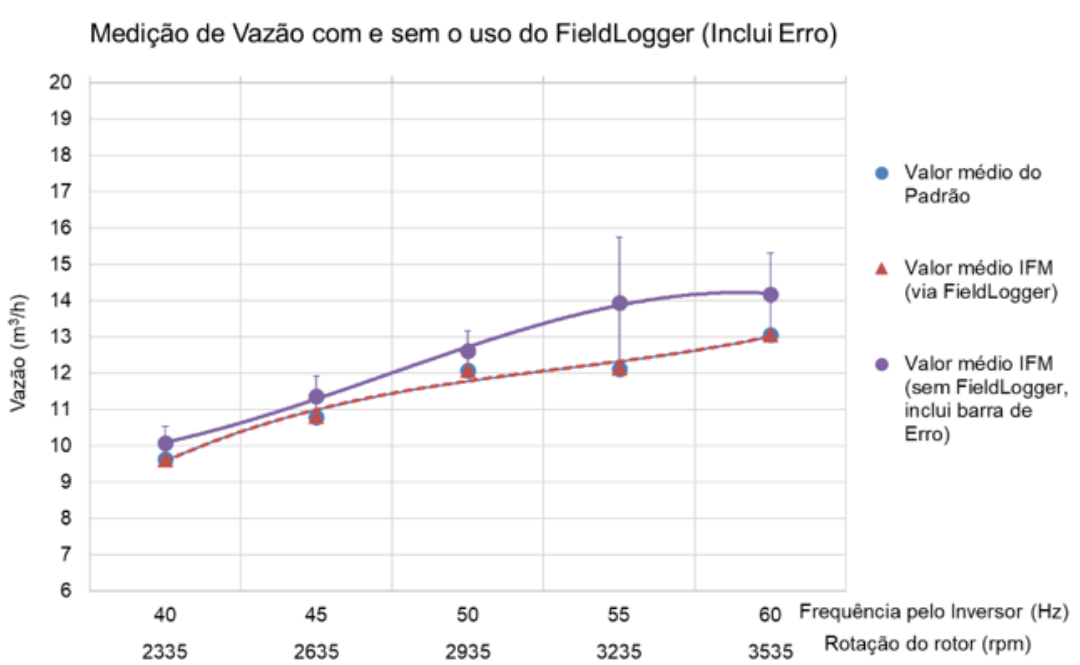

Figura 58 - Medição de vazão com e sem o uso do FieldLogger (Inclui Erro)

O aumento do número de medidas implica no aumento do tempo amostral, contribuindo para que a média da totalidade das medidas represente o valor real da vazão.

\subsection{3}

\section{Calibração do subsistema de medição de pressão}

Nesta seção é apresentado o resultado da calibração dos transdutores de pressão do tipo resistivo, instalados no Sistema Injetor e Receptor de Esferas Abrasivas 3 (SIREA 3). A medição da pressão do fluido de trabalho na entrada e na saída do trocador de calor permite não apenas avaliar a perda de pressão ("perda de carga") imposta pela incrustação que se forma no interior dos tubos do trocador, como, também, avaliar as condições hidrodinâmicas do trocador de calor. Cabe ressaltar que é o próprio fluido de trabalho do trocador que transporta as esferas abrasivas utilizadas pela técnica de limpeza de trocadores de calor. Nesse sentido, conhecer a hidrodinâmica do escoamento é importante para assegurar condições adequadas capazes de evitar que as esferas abrasivas utilizadas na limpeza fiquem presas dentro dos tubos do trocador.

\subsubsection{1}

\section{Caracterização do subsistema de medição de pressão}

A seguir, descrevem-se as características técnicas e metrológicas de interesse do medidor de pressão padrão, com certificado de calibração apresentado no Anexo $\mathrm{B}$, utilizado para a calibração dos transdutores de pressão instalados no SIREA 3.

- Padrão: Medidor de pressão (fabricante Salvi Casagrande; modelo Salvpress 100B; número de série: 0006300-01);

- Resolução: $0,01 \mathrm{kgf} / \mathrm{cm}^{2}$. 
A Figura 59 apresenta o manômetro Salvi Casagrande utilizado como padrão de calibração para os transdutores de pressão instalados no SIREA 3, assim assegurando rastreabilidade ao Sistema Internacional de Unidades (SI), já que foi calibrado por um laboratório acreditado da Rede RBC/INMETRO.

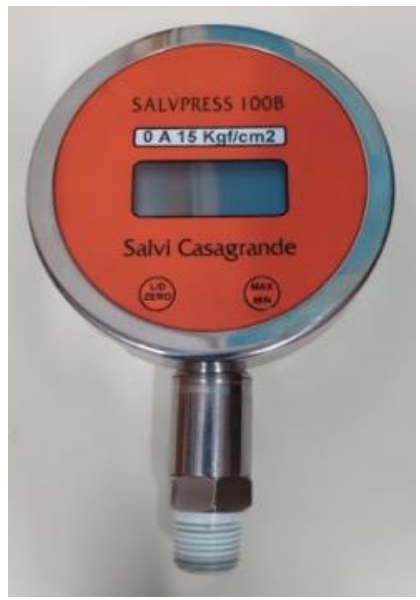

Figura 59 - Manômetro digital Salvi Casagrande (padrão)

Os transdutores de pressão calibrados e suas respectivas características técnicas e metrológicas, de interesse, são descritos a seguir:

- Transmissor de pressão resistivo (fabricante Wika; modelo S-11; número de série: 110B5VMP) identificado como $\mathrm{P1}$; resolução: 0,1 bar;

- Transmissor de pressão resistivo (fabricante Wika; modelo S-11; número de série: 110B9MIC) identificado como P2; resolução: 0,1 bar;

- Transmissor de pressão resistivo (fabricante Wika; modelo S-11; número de série: 110B5VMP) identificado como P3; resolução: 0,1 bar;

- Medidor de pressão diferencial (fabricante Novus; modelo NP860-HRT-8; número de série: 8800900080 ) identificado como $P_{\text {dif; }}$ resolução: 0,01 bar.

A Figura 60 apresenta os transdutores e o medidor de pressão diferencial calibrados, que compõem o subsistema de pressão.

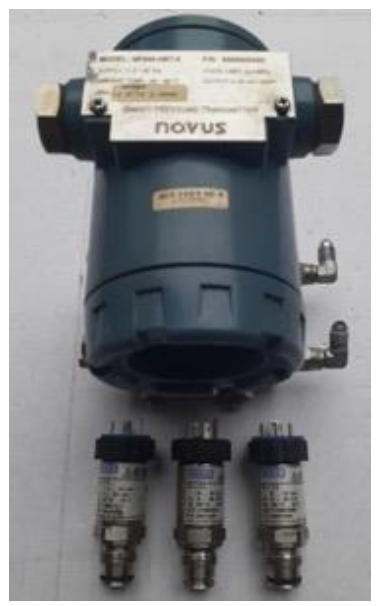

Figura 60 - Instrumentos calibrados do subsistema de pressão 


\subsubsection{2}

\section{Resultados da calibração do subsistema de medição de pressão}

A determinação dos valores de incerteza dos medidores de pressão calibrados é discutida na seção 4.1, que descreve os procedimentos necessários para a calibração de um instrumento de medição.

A Figura 61 apresenta o aparato experimental utilizado para a determinação das incertezas de medição associadas às medições realizadas pelos instrumentos medidores de pressão embarcados no SIREA 3.

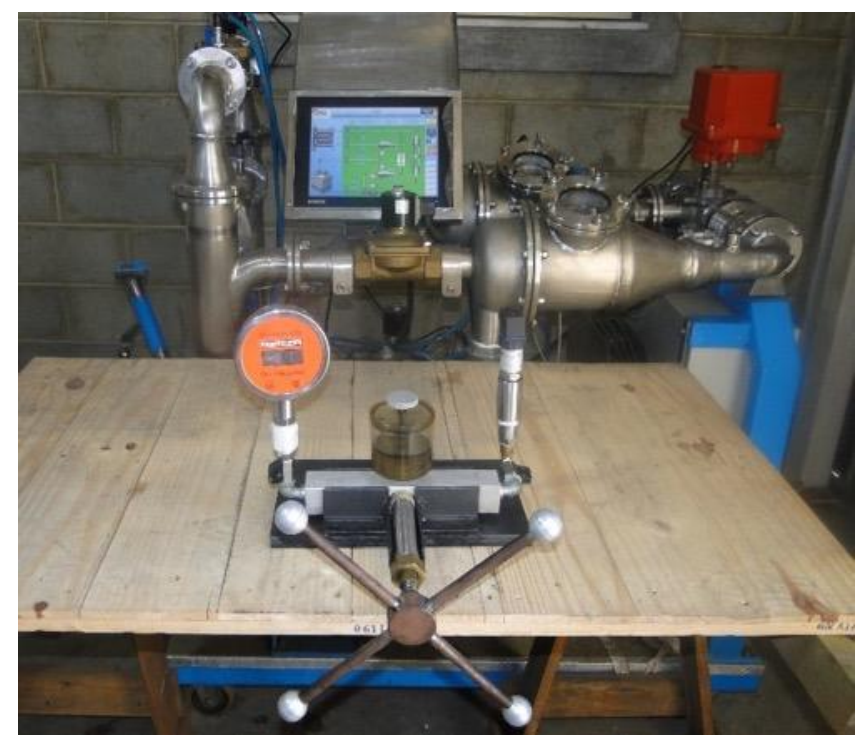

Figura 61 - Aparato experimental montado para a calibração dos instrumentos de pressão

As Tabelas 35-36, do Apêndice D, apresentam os dados da calibração dos medidores de pressão. As Tabelas 39-44 documentam: (i) os valores das incertezas associadas a cada valor de referência de medição utilizado na calibração; (ii) o valor do Fator de Abrangência $k$, para cada calibração, calculado a partir do valor $t$-Student, para um nível de confiança de 95,0\%. O valor máximo de incerteza expandida, obtido para cada medidor de pressão calibrado é apresentado a seguir:

$$
\boldsymbol{U}_{\boldsymbol{m a ́} \boldsymbol{x} \boldsymbol{P 1}}=0,03 \text { bar; } \boldsymbol{U}_{\boldsymbol{m a ́} \boldsymbol{x} \boldsymbol{P 2}}=0,01 \text { bar; } \boldsymbol{U}_{\boldsymbol{m a ́} \boldsymbol{x} \boldsymbol{P 3}}=0,02 \text { bar e } \boldsymbol{U}_{\text {máxPdif }}=0,11 \text { bar }
$$

A seguir, as Equações (23), (24), (25) e (26) apresentam o polinômio de ajuste obtido para cada medidor de pressão (bar):

$$
\begin{aligned}
& \text { Pajust }_{P 1}=1,015 x-0,014 \\
& \text { Pajust }_{P 2}=1,015 x-0,012 \\
& \text { Pajust }_{P 3}=1,015 x-0,013
\end{aligned}
$$




$$
\text { Pajust }_{\text {Pdif }}=0,990 x-0,022
$$

A calibração dos medidores de pressão apresenta valores específicos que dizem respeito a determinadas características inerentes ao comportamento dos medidores calibrados. Essas características são denominadas "Características Metrológicas", a seguir denominadas:

- Erro fiducial;

- Histerese;

- Repetibilidade;

- Linearidade.

Erro fiducial é o valor absoluto do extremo do erro de medição, com respeito a um valor de referência conhecido (INMETRO, 2010). O erro fiducial é determinado pela relação entre o maior erro de medição do instrumento pela amplitude de medição expressa em percentagem.

A histerese ${ }^{6}$ é determinada em um mesmo ponto nominal de pressão, pelo valor absoluto da razão percentual entre a diferença máxima das indicações do instrumento em um dos ciclos (carregamento e descarregamento) e a amplitude de medição (INMETRO, 2010). A Figura 62 apresenta no gráfico as "curvas de histerese" de um determinado instrumento.

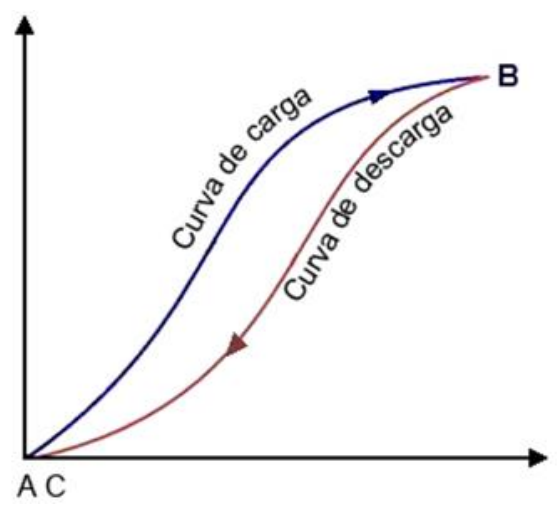

Figura 62 - Curvas de carga e descarga em ciclo histerético

A repetibilidade é a variação das medidas obtidas por um único operador, utilizando o mesmo equipamento de medição e método, ao medir repetidas vezes uma mesma grandeza de uma única peça, por exemplo.

A linearidade mede a variação da diferença entre a média dos valores de medição de uma grandeza e o valor de referência para a grandeza medida, realizadas por um calibrador para diferentes valores de referência na faixa de

\footnotetext{
${ }^{6}$ Histerese é o comportamento de um determinado instrumento em apresentar diferentes valores correspondes ao mesmo ponto de grandeza observada sob carregamento e descarregamento.
} 
interesse. Os valores das características metrológicas dos medidores calibrados estão apresentados na Tabela 13.

Tabela 13 - Características metrológicas dos medidores calibrados

\begin{tabular}{ccccc}
\hline \multicolumn{5}{c}{ Características metrológicas } \\
Medidor & $\begin{array}{c}\text { Erro fiducial } \\
\text { Histerese } \\
(\%)\end{array}$ & $\begin{array}{c}\text { Repetibilidade } \\
(\%)\end{array}$ & $\begin{array}{c}\text { Linearidade } \\
(\%)\end{array}$ \\
P1 & 1,46 & 0,41 & 0,41 & 0,38 \\
P2 & 1,36 & 0,10 & 0,10 & 0,11 \\
P3 & 1,36 & 0,30 & 0,30 & 0,18 \\
Pdif & 2,64 & 2,00 & 2,80 & 1,92 \\
\hline
\end{tabular}

\subsection{4}

\section{Calibração do subsistema de medição de temperatura}

Nesta seção é apresentado o resultado da calibração das termorresistências do tipo Pt100, instalados no Sistema Injetor e Receptor de Esferas Abrasivas 3 (SIREA 3). Conforme descrito nos capítulos anteriores, a medição de temperatura dos fluidos de trabalho do trocador pelas termorresistências do tipo Pt100 são requeridas para o cálculo da efetividade do trocador de calor. Daí a necessidade de assegurar uma adequada confiabilidade metrológica dos instrumentos de medição, já que a efetividade se constitui em importante indicador para se avaliar a eficácia dos mecanismos de troca de calor entre os fluidos de trabalho do TC.

\subsubsection{1}

\section{Caracterização do subsistema de medição de temperatura}

Os instrumentos de medição calibrados são caracterizados, a seguir:

- Termorresistências: duas unidades, do tipo Pt100 (números de série: 25004 e 25001), identificados nas tabelas de dados por $\mathrm{TS}_{1}$ e $\mathrm{TS}_{2}$, respectivamente;

- Fabricante: Salvi Casagrande;

- Modelo: TR 315;

- Resolução: $0,1^{\circ} \mathrm{C}$.

O padrão de temperatura utilizado é o sensor embarcado no banho térmico, cuja descrição e caracterização é definida abaixo e certificado de calibração consta no Anexo C:

- Padrão: banho térmico (Fabricante Haake; Modelo TYP 002-9979; número de série: 198000400/016), cujos valores lidos são identificados por TP na Tabela 45 do Apêndice E;

- Resolução: $0,1^{\circ} \mathrm{C}$.

A Tabela 45 do Apêndice $E$ resume os dados da calibração, que foi realizada em observância às recomendações e às boas práticas de calibração de instrumentos de medição. A Figura 63 mostra o sistema montado para a calibração das termorresistências. 


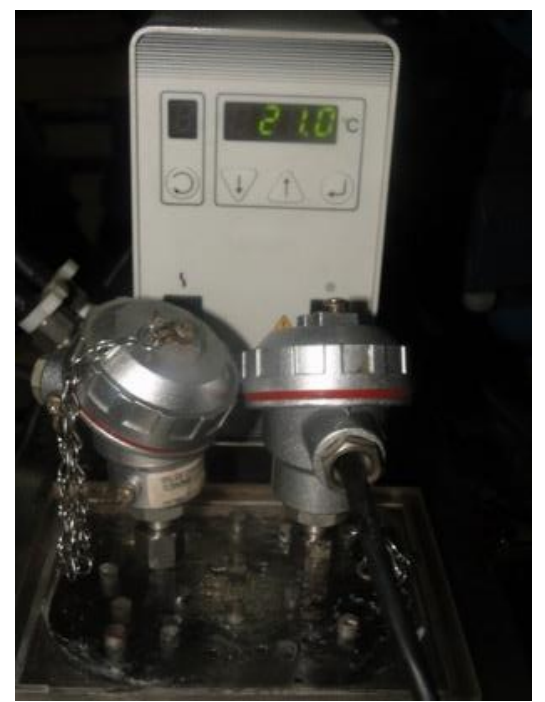

Figura 63 - Aparato experimental de calibração das termorresistências Pt 100

O polinômio de ajuste dos valores de temperatura indicados pelo banho térmico foi obtido a partir da comparação dos valores de temperatura indicados pelo banho térmico com os valores indicados por um termômetro calibrado, utilizado como padrão para calibração conjunto sensor e display do banho térmico - Termômetro de Líquido em Vidro de Mercúrio (TLV) - Incotherm Modelo 12616; Cert: 0062. A equação do polinômio de ajuste do banho é dada pela equação (27):

$$
y(x)=-0,0002 x^{2}+1,1077 x-0,1371
$$

Esses valores "corrigidos" pelo polinômio de ajuste do padrão são apresentados como TP corr e TP $_{\text {corr2 }}$ na Tabela 1 do Apêndice $E$. A média aritmética dos valores corrigidos $\mathrm{TP}_{\text {corr1 }}$ e $\mathrm{TP}_{\text {corr2 }}$ é dada por TP médio que também está apresentado na Tabela 45.

\subsubsection{2}

\section{Resultados da calibração das termorresistências Pt 100}

A calibração das termorresistências do tipo Pt 100 foi realizada com base nos procedimentos apresentados na seção 4.1, que expõe os procedimentos necessários para a calibração de um instrumento de medição. Para as calibrações realizadas, os polinômios de ajuste dos Pt100 referenciados $\mathrm{TS}_{1}$ e $\mathrm{TS}_{2}$ são mostrados nas equações (28) e (29), respectivamente:

$$
\begin{aligned}
& y\left(T S_{1}\right)=+1,013\left(T S_{1}\right)-0,425 \\
& y\left(T S_{2}\right)=+1,007\left(T S_{2}\right)-0,436
\end{aligned}
$$


Os valores de incerteza associada a cada um dos polinômios de ajuste ( $\mathrm{Pt}$ 100 TS $_{1}$ e TS 2 ), calculados pela equação (15), são, a seguir, apresentados:

$$
u T S_{1 a j u s t}=0,0554^{\circ} \mathrm{C} \text { e } u T S_{2 a j u s t}=0,0921^{\circ} \mathrm{C}
$$

Os dados e procedimentos para obtenção dos coeficientes dos polinômios de ajuste, e respectivas incertezas associadas, estão apresentados nas Tabelas 46- 49 do apêndice $E$.

Conforme é mostrado na Tabela 49 do Apêndice E, o polinômio que apresenta a menor incerteza associada é o de grau 1, o que se verificou para ambos os casos. Calculado a partir do valor $t$-Student, para um nível de confiança de $95,0 \%$, e para as condições experimentais apresentadas $(\mathrm{N}=15$, polinômio de ajuste do grau 1) o fator de abrangência $k$ encontrado é igual a 2,16.

Uma vez determinado o valor do componente de incerteza associado ao polinômio de ajuste, é possível calcular a incerteza total expandida associada às medições realizadas pelas termorresistências $\mathrm{TS}_{1}$ e $\mathrm{TS}_{2}$. As incertezas expandidas associadas às medições, apresentados na equação (7), realizadas por essas termorresistências, com confiabilidade de 95,0 \%, são assim calculadas:

$$
\begin{gathered}
U_{T S 1}=\sqrt{(2 * 0,0289)^{2}+0,2^{2}+0^{2}+(2,16 * 0,0554)^{2}}=0,2^{\circ} \mathrm{C} \quad \mathrm{e} \\
U_{T S 2}=\sqrt{(2 * 0,0289)^{2}+0,2^{2}+0^{2}+(2,16 * 0,0921)^{2}}=0,3{ }^{\circ} \mathrm{C}
\end{gathered}
$$

Os valores utilizados para conseguir esses resultados de incertezas estão mostrados na Tabela 45 do Apêndice $E$.

$\mathrm{Na}$ sequência, a Figura 64 plota as incertezas associadas às medições realizadas por $\mathrm{TS}_{1}, \mathrm{TS}_{2}$ e à temperatura indicada pelo padrão, todas corrigidas pelos respectivos polinômios de ajuste.

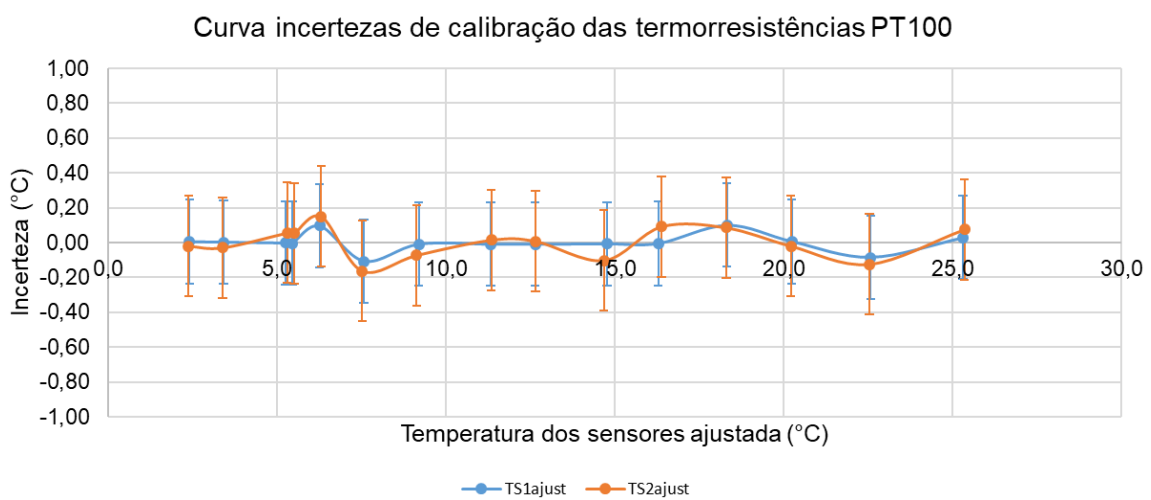

Figura 64 - Resultados das calibrações dos sensores de temperatura 
Os dados que geraram o gráfico da Figura 64 estão apresentados na Tabela 50 do Apêndice E. Como pode-se observar, o erro máximo associado às medições ajustadas é $0,1^{\circ} \mathrm{C}$ para o caso de $\mathrm{TS}_{1}$ e de $0,2{ }^{\circ} \mathrm{C}$, para o caso de $\mathrm{TS}_{2}$. Esses níveis de erro e de incerteza dos instrumentos de medição instalados no dispositivo de limpeza de trocador de calor são compatíveis com a tolerância admitida pelo uso do sistema SIREA 3.

\section{3}

\section{Automação do sistema de medição}

O sistema de automação embarcado no SIREA 3 é responsável pelo seu funcionamento como um todo. Controla a abertura e fechamento das válvulas solenoides instaladas (assim controlando os fluxos nos diferentes circuitos hidráulicos do equipamento), controla a entrada e saída da bomba hidráulica e a frequência de funcionamento do grupo motor bomba, bem como o processo de coleta dos dados de medição e seu tratamento e transmissão de dados em tempo real, de todos os medidores que compõem os quatro subsistemas de medição embarcados no SIREA 3.

Como já mostrado na seção 3.1, as informações do funcionamento e valores de medição de todos esses dispositivos são mostradas em uma tela touch screen, que integra a interface homem-máquina (IHM) instalada no painel do sistema de automação do SIREA 3.

\section{4}

\section{Considerações sobre o capítulo}

Conforme discutido neste capítulo, o sistema de limpeza de trocadores de calor por esferas abrasivas (SIREA 3) encontra-se qualificado para desempenhar suas duas funções: (i) operar como dispositivo de limpeza de trocadores de calor (injetando e recuperando esferas abrasivas para desobstruir os tubos do trocador) sem a necessidade de interromper a geração e (ii) operar como um sistema automatizado de calibração de instrumentos de medição de pressão e vazão. 


\section{5 Incorporação de melhorias no dispositivo de limpeza}

Não obstante o funcionamento e desempenho operacional do dispositivo de limpeza de trocadores de calor de hidrogeradores (objeto desta pesquisa de mestrado) ter sido validado em laboratório, é importante ter em mente que, originalmente, este dispositivo foi concebido para ser utilizado no ambiente de uma usina hidrelétrica, onde o consumo de água e de energia elétrica não constituem preocupação dos gestores da usina. Entretanto, ao generalizar o seu uso para realizar a limpeza de trocadores de calor de outros equipamentos industriais, o consumo de água e energia devem ser considerados fatores críticos decisivos para se avaliar o custo/benefício de utilização desta alternativa tecnológica de limpeza. Este é o preceito básico que motiva um dos objetivos complementares desta pesquisa de mestrado, mais especificamente, agregar melhorias incrementais capazes de otimizar o funcionamento do SIREA 3, quer (i) melhorando o desempenho hidrodinâmico dos diferentes circuitos hidráulicos do equipamento, quer (ii) adequando o nível de pressão do fluxo que transporta a esfera para o interior dos tubos do trocador de calor ao nível da pressão de trabalho do trocador de calor. Desta forma criam-se condições favoráveis capazes de otimizar o processo de remoção da indesejável incrustação que, inevitavelmente, se acumula nas passagens internas dos tubos do trocador.

Este capítulo resume os ensaios que foram realizados para mapear e quantificar as perdas de carga (perdas de pressão) impostas pela configuração e geometrias dos tramos/conexões hidráulicos do equipamento original (versão 1.0 do SIREA 3), cujos resultados orientaram modificações no projeto original, que permitiram fazer ajustes construtivos que resultaram na versão 2.0 do SIREA 3.

\section{1}

\section{Versão 1.0 do SIREA 3}

A Figura 27 no Capítulo 3 ilustra a versão 1.0 do SIREA 3, cujas características construtivas e funcionais são apresentadas abaixo:

- Grupo motor-bomba hidráulica: modelo CAM 415 TJM, potência $4 \mathrm{cv}$, rotor de $138 \mathrm{~mm}$ e tensão de alimentação de $220 \mathrm{~V} / 380 \mathrm{~V}$;

- Instrumentação embarcada: três transdutores de pressão do tipo resistivo, um medidor de pressão diferencial, um contador de esferas do tipo duplo (CONDE duplo) e duas termorresistências do tipo Pt100, uma bomba hidráulica, que opera com uma vazão máxima de $20,0 \mathrm{~m}^{3} / \mathrm{h}$ - a $60 \mathrm{~Hz}$ (3535 rpm), que é a rotação máxima do rotor -, condição de funcionamento essa que impõe uma pressão máxima de 3,30 bar no sistema. 
O caráter inovador do projeto SIREA é dado pela criatividade da concepção do dispositivo de injetar e recuperar esferas abrasivas ao término de cada ciclo de limpeza, assim evitando a perda das esferas nos reservatórios de água de alimentação. Contudo, conforme identificado pelos dados acima, é o grupo motorbomba (devidamente assistido pelo inversor de frequência a ele acoplado) que assegura as condições operacionais de funcionamento do dispositivo de limpeza. A Figura 40 (do Capítulo 4) apresenta a curva de calibração da bomba hidráulica do grupo motor-bomba instalado na versão 1.0 do SIREA 3, não apenas exibindo suas respectivas características hidráulicas como, também, permitindo determinar a curva de funcionamento da bomba como uma alternativa redundante de medidor de vazão do fluido de trabalho.

O desempenho da versão 1.0 do SIREA foi mapeado pela medição da "perda de carga" (queda de pressão) nos tramos críticos dos circuitos hidráulicos do equipamento. A Figura 65 ilustra, de forma esquemática, os pontos críticos alterados do SIREA 3, a seguir indicados.

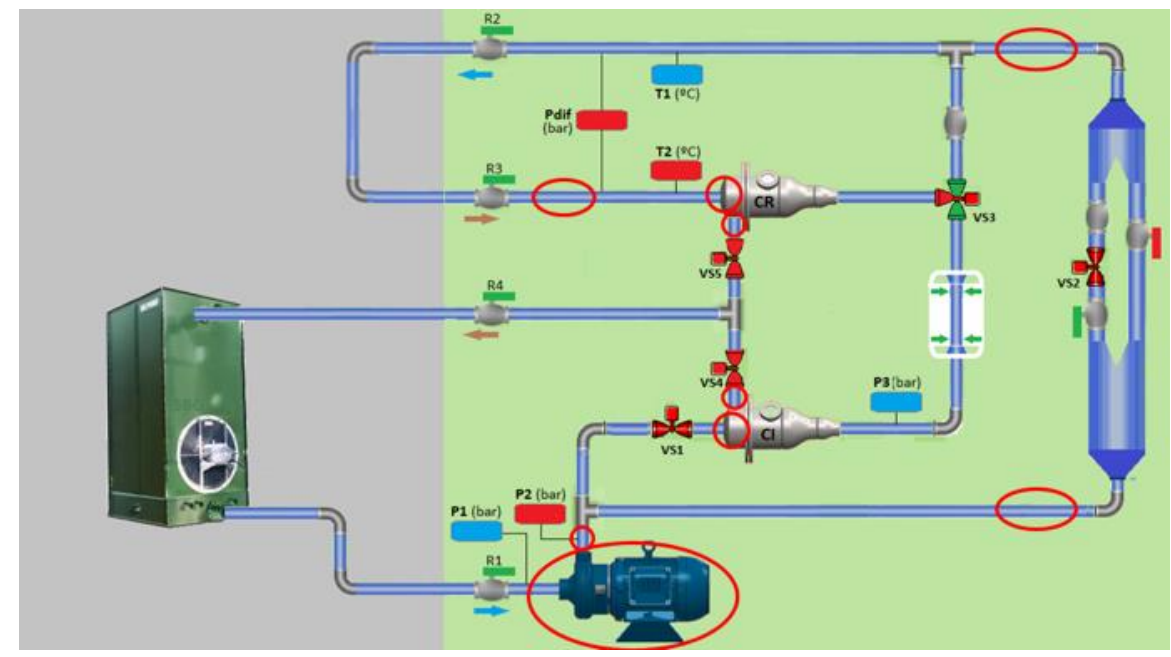

Figura 65 - Esquemático de pontos alterados do sistema

Caracterização dos pontos críticos factíveis de serem alterados visando reduzir a perda de carga nos tramos do SIREA:

- entradas e saídas das câmaras de injeção e recuperação, visando diminuir o coeficiente de perda localizada de pressão;

- tramo de retorno do trocador de calor, para instalação do medidor de vazão magnético Endress Hauser, assim tornando possível o dispositivo desempenhar a sua função de Calibrador do SIREA 3;

- tubo de recalque, para prover informações críticas que permitem orientar sobre a necessidade de substituir o grupo motor-bomba do SIREA 3 para adequá-lo a outras aplicações industriais e/ou para atender a especificações técnicas de trocadores de calor de outros portes (seção 2.3.3). 
Para mensurar a perda de carga em tramos críticos do SIREA 3, pontos críticos de medição foram determinados em segmentos hidráulicos do sistema de limpeza. Esses segmentos foram selecionados em função de peculiaridades do dispositivo de limpeza, mais especificamente, a geometria de conexões utilizadas nos tramos hidráulicos, elementos internos presentes em componentes que estão contidos nos tramos (e.g. câmaras de injeção e recuperação), conexões de transição entre diferentes bitolas da tubulação.

A Figura 66 identifica os trechos selecionados para medição e monitoramento da pressão nos tramos críticos do dispositivo de limpeza.

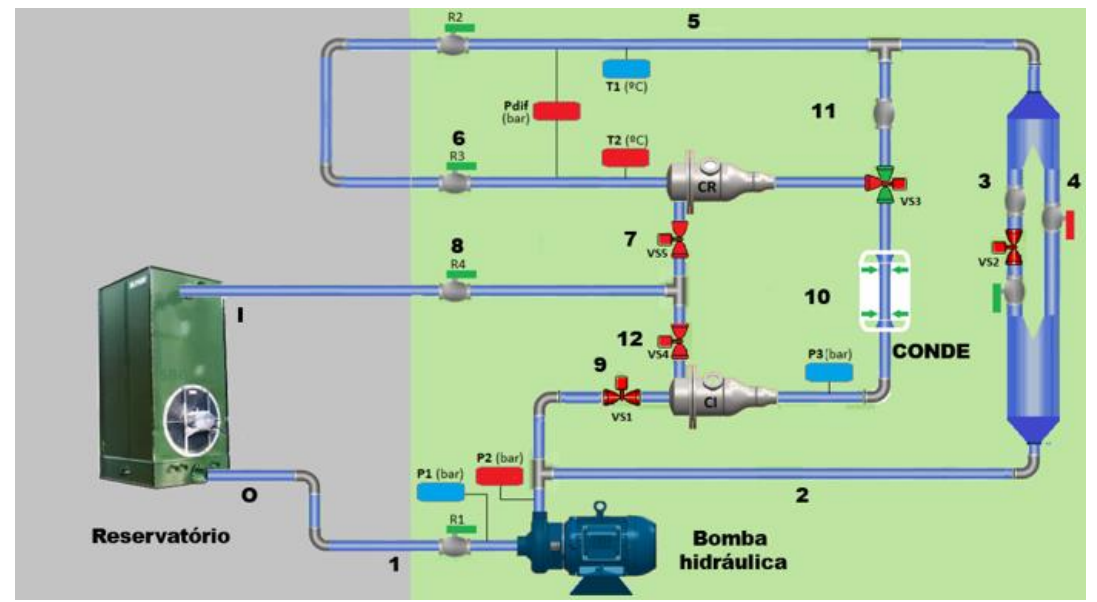

Figura 66 - Esquemático do circuito hidráulico

São selecionados cinco diferentes tramos hidráulicos que se iniciam e terminam no reservatório indicado na Figura 65. Nessa figura, os pontos "l" e "O" denotam, respectivamente, as seções de "entrada" e de "saída" do reservatório de abastecimento. Já o ponto "1" denota a seção de entrada na bomba hidráulica.

Os tramos hidráulicos foram selecionados em função do fluxo gerado pela bomba hidráulica, ou seja, do fluxo nos trechos ou componentes críticos, que foram alterados para permitir uma redução da perda de carga nessas seções.

\subsection{1}

\section{Medição de perdas de carga localizadas em tramos pré-selecionados}

Os dados da Tabela 14 documentam os resultados das pressões medidas (pressão na admissão e recalque da bomba hidráulica, P1 e P2 respectivamente, e diferença de pressão nos pontos indicados, $\Delta p$ ) nesses tramos, assim permitindo documentar, para diferentes condições hidrodinâmicas de operação, a perda de carga em trechos críticos dos tramos hidráulicos estudados. 
Tabela 14 - Perda de carga imposta pelos tramos hidráulicos

\begin{tabular}{|c|c|c|c|c|c|c|}
\hline \multirow[t]{2}{*}{$\begin{array}{c}\text { Tramo } \\
\text { hidráulico }\end{array}$} & \multirow[t]{2}{*}{$\begin{array}{c}\text { Frequência } \\
\text { da bomba }(\mathrm{Hz})\end{array}$} & \multicolumn{3}{|c|}{$\begin{array}{c}\text { Pontos de medição } \\
\text { (bar) }\end{array}$} & \multirow{2}{*}{$\begin{array}{c}\text { Perda de } \\
\text { carga (bar) } \\
\Delta \mathrm{p}\end{array}$} & \multirow[t]{2}{*}{$\begin{array}{l}\text { Vazão } \\
\left(\mathrm{m}^{3} / \mathrm{h}\right)\end{array}$} \\
\hline & & P1 & P2 & P3 & & \\
\hline \multirow{5}{*}{$\# 1$} & 60 & 0,20 & 3,08 & 2,31 & 1,82 & 17,12 \\
\hline & 55 & 0,13 & 2,62 & 2,00 & 1,54 & 15,78 \\
\hline & 50 & 0,11 & 2,21 & 1,63 & 1,24 & 14,18 \\
\hline & 45 & 0,20 & 1,83 & 1,34 & 1,04 & 12,72 \\
\hline & 40 & 0,20 & 1,48 & 1,05 & 0,80 & 11,20 \\
\hline \#2 & 56 & 0,13 & 2,73 & --- & 1,90 & 20,00 \\
\hline \multirow{5}{*}{ \#3 } & 60 & 0,20 & 3,21 & --- & 2,06 & 15,06 \\
\hline & 55 & 0,25 & 2,76 & --- & 1,75 & 13,88 \\
\hline & 50 & 0,21 & 2,30 & --- & 1,44 & 12,60 \\
\hline & 45 & 0,20 & 1,88 & --- & 1,15 & 11,36 \\
\hline & 40 & 0,22 & 1,52 & --- & 0,90 & 10,08 \\
\hline \multirow{5}{*}{ \#4 } & 60 & 0,27 & 3,30 & 2,82 & 2,73 & 12,56 \\
\hline & 55 & 0,24 & 2,85 & 2,43 & 2,31 & 11,64 \\
\hline & 50 & 0,28 & 2,36 & 1,90 & 1,90 & 10,54 \\
\hline & 45 & 0,30 & 1,95 & 1,52 & 1,52 & 9,36 \\
\hline & 40 & 0,23 & 1,56 & 1,19 & 1,19 & 8,26 \\
\hline \multirow{5}{*}{ \#5 } & 60 & 0,23 & 3,20 & --- & 2,13 & 15,02 \\
\hline & 55 & 0,22 & 2,80 & --- & 1,81 & 13,82 \\
\hline & 50 & 0,21 & 2,30 & --- & 1,49 & 12,62 \\
\hline & 45 & 0,22 & 1,89 & --- & 1,16 & 11,38 \\
\hline & 40 & 0,23 & 1,51 & --- & 0,91 & 10,14 \\
\hline
\end{tabular}

\subsection{2}

\section{Modificações no circuito hidráulico (alteração no projeto construtivo)}

Com o propósito de reduzir as perdas de cargas no circuito hidráulico da versão 1.0 do SIREA 3 (documentado na Tabela 14), alterações foram realizadas no projeto construtivo dos respectivos tramos hidráulicos. Essas alterações construtivas objetivaram suavizar a hidrodinâmica do escoamento nessas seções consideradas críticas. A diminuição da perda de carga foi conseguida evitando-se alargamentos bruscos, desvios desnecessários do escoamento, redução/aumento da velocidade do escoamento e tratamento das superfícies internas das conexões para reduzir 0 atrito durante o escoamento.

A Figura 67 destaca os principais componentes do sistema de limpeza que foram modificados. 


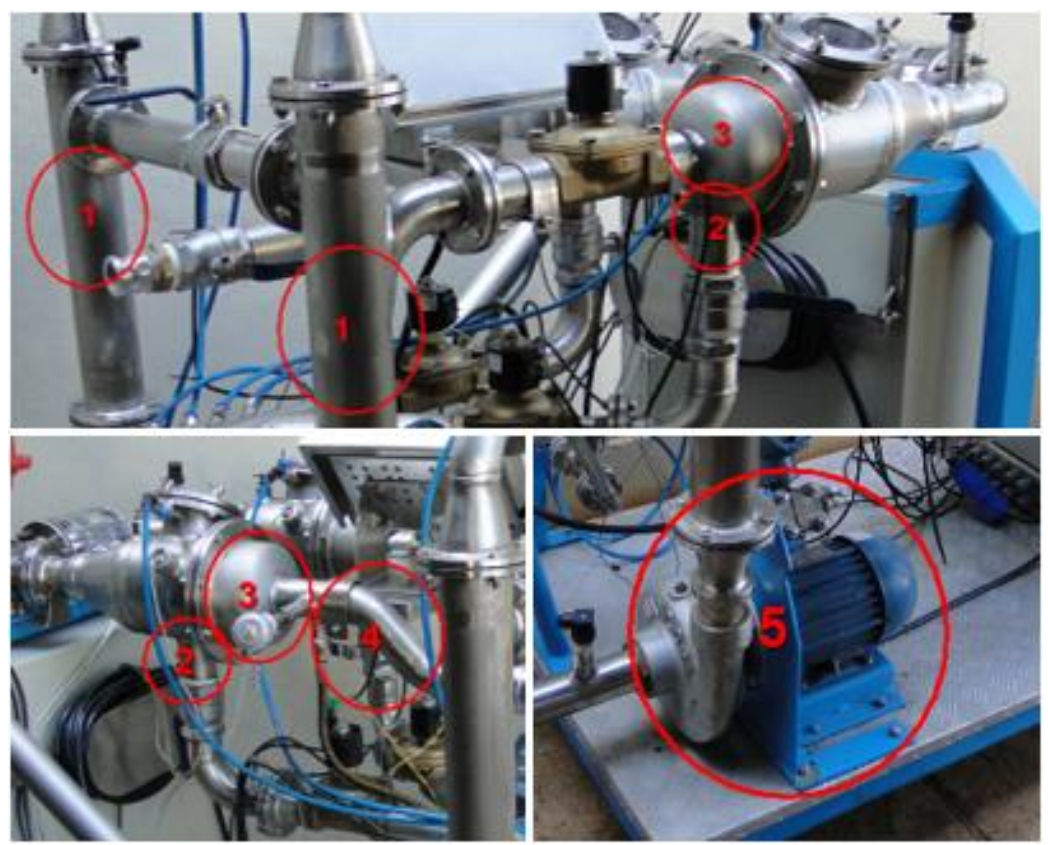

Figura 67 - Alterações realizadas em componentes do sistema de limpeza

Os elementos destacados e referenciados por números nas imagens da Figura 66 foram alterados para atender aos requisitos técnicos e operacionais de funcionamento do dispositivo de limpeza. Os tópicos numerados a seguir referemse aos elementos destacados na Figura 67, com os respectivos números apresentados na figura.

1 - alteração nas colunas verticais para permitir a instalação de um medidor de vazão (do fabricante Endress Hauser), utilizado como medidor padrão de vazão do SIREA 3;

2 - substituição da conexão de descarga da câmara de injeção e recuperação de esferas. Uma conexão cônica substituiu a conexão reta mostrada na figura. Essa alteração permitiu diminuir 0 coeficiente de perda localizada $K$ (cujo valor pode ser calculado experimentalmente), sendo $K \circ$ fator adimensional, dado pela equação $\Delta H_{l o c}=K \frac{V^{2}}{2 g}$ ).

3 - alteração da configuração interna das conexões do tipo caps, de 6 polegadas, existentes na versão 1.0 do SIREA 3. A alteração consiste na introdução de uma conexão intermediária, na forma de tronco de cone, de 2 polegadas de diâmetro na base da tubulação e outra de 6 polegadas de diâmetro (diâmetro do tubo central das câmaras de injeção e recuperação). O objetivo desta alteração foi eliminar a expansão brusca que resulta da mudança de diâmetro dos tubos de 2 polegadas para 6 polegadas, eliminando, assim, a formação de vórtices formados nos cantos dos caps, causado pela expansão abrupta, alteração esta que diminui o fator $K$ de perda de carga localizada;

4 - substituição do tramo de retorno à Câmara de Recuperação, para assegurar um trecho reto de tubulação a montante do medidor de vazão Endress Hauser instalado no sistema;

5 - substituição da bomba hidráulica Dancor, Modelo 415 TJM, de 4 cv potência, pela bomba KSB, Modelo METB 065-040-200, de 20 cv de 
potência. A substituição do grupo motor-bomba requereu alterações no acoplamento do novo grupo motor bomba hidráulica.

\section{2}

\section{Versão 2.0 do SIREA 3}

As modificações estruturais nas conexões realizadas no SIREA 3 alteraram as condições de trabalho e o seu desempenho. A nova versão do equipamento otimizado (versão 2.0 do SIREA 3) será, doravante, denominada SIREA 3.

\subsection{1}

\section{Melhorias introduzidas no sistema de limpeza}

O resultado das alterações no projeto constitutivo (conexões e tubulações) descritas na seção 5.1 .2 são destacadas na Figura 68 abaixo.

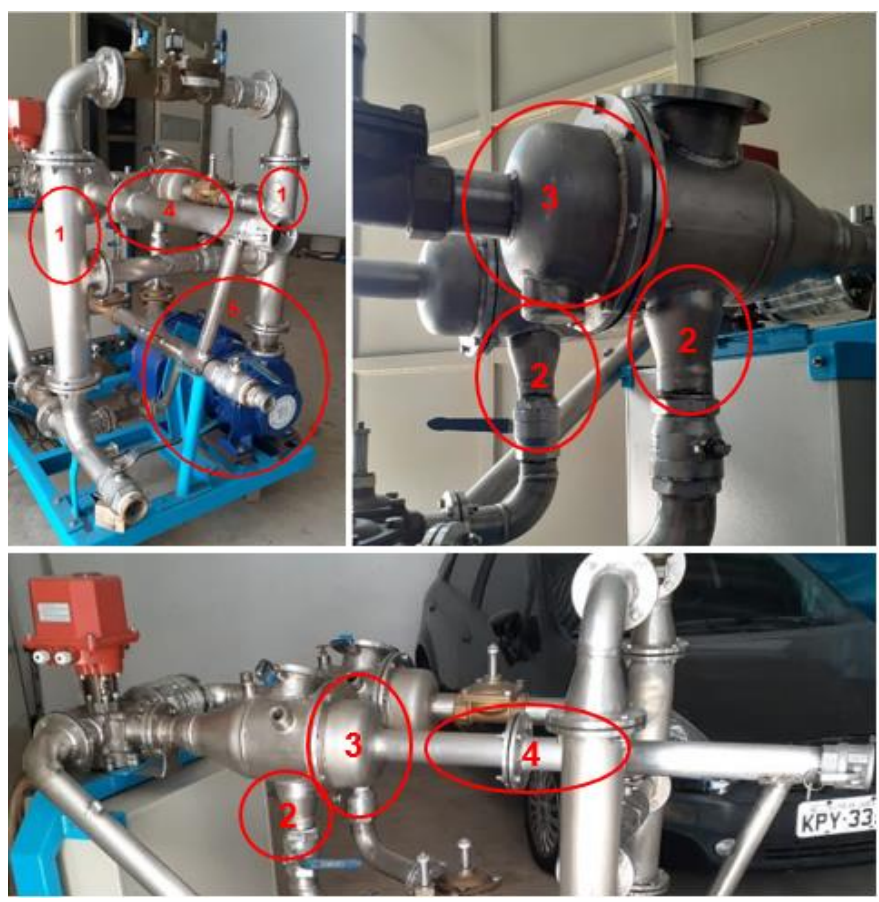

Figura 68 - Resultado das alterações realizadas no sistema de limpeza

\section{2 .2}

\section{Avaliação das melhorias introduzidas}

Em virtude de restrições de segurança impostas pelas autoridades sanitárias em um cenário de pandemia ainda em curso não foi possível realizar o ensaio de estanqueidade após as intervenções no sistema de limpeza. Por seguinte, não foi possível realizar o ensaio que quantificaria o ganho de desempenho hidrodinâmico devido à redução de perda de carga imposta pelo sistema. Contudo, uma projeção de redução dos valores de coeficientes de perda de carga localizadas $K$ das conexões e estruturas alteradas (Figura 67 e 68) são apresentadas na Tabela 15. 
Os dados utilizados para as projeções estão presentes na literatura específica (Fox et al., 2016).

Tabela 15 - Perdas de cargas impostas pelos tramos hidráulicos após alterações

\begin{tabular}{cccc}
\hline $\begin{array}{c}\text { Conexão / } \\
\text { estrutura alterada }\end{array}$ & $\begin{array}{c}\text { Kanterior à } \\
\text { mudança }\end{array}$ & $\begin{array}{c}\text { K posterior à } \\
\text { mudança }\end{array}$ & $\begin{array}{c}\text { Redução percentual de } K \\
(\%)\end{array}$ \\
2 & 0,50 & 0,30 & 40,0 \\
\hline 3 & 0,79 & 0,40 & 49,4 \\
\hline 4 & 0,40 & 0,04 & 90,0 \\
\hline
\end{tabular}

Conforme apresentado na Tabela 15, a redução dos valores de $K$ teórico são significativos e refletem diretamente na perda de carga conforme é descrito na fórmula $\Delta H_{l o c}=K \frac{V^{2}}{2 g}$. 


\section{6 \\ Conclusões e recomendações}

Em sintonia com o objetivo central originalmente proposto, esta dissertação de mestrado avaliou em laboratório o desempenho funcional de um dispositivo de limpeza que faz uso de esferas abrasivas para mitigar indesejáveis incrustações em trocadores de calor industriais. Fundamentado nos ensaios realizados, incrementou-se melhorias e inovações visando adequar o dispositivo a diferentes portes de trocadores de calor tendo como preceito a redução dos custos de bombeamento e a otimização dos ciclos de limpeza.

\section{1}

\section{Conclusões}

No que concerne ao primeiro objetivo específico, e fundamentado em pesquisa bibliográfica realizada na literatura especializada, identificou-se e caracterizou-se as alternativas tecnológicas documentadas para limpeza de trocadores de calor (Capítulo 3 da dissertação), o que permitiu confirmar a originalidade do dispositivo de limpeza concebido pelo Programa de PósGraduação em Metrologia da PUC-Rio. Dentre suas características funcionais, o sistema avaliado inova ao propor um sistema móvel compacto, totalmente automatizado, de fácil acoplamento e adaptável a diferentes portes de trocadores de calor, incluindo uma alternativa de ciclos intermediários de limpeza das esferas abrasivas entre ciclos de limpeza dos tubos do trocador, sem a necessidade de interromper o processo industrial que faz uso dos trocadores de calor.

No que concerne ao objetivo específico relacionado à determinação do número ótimo de ciclos de operação do dispositivo para assegurar eficácia do processo de limpeza (Capítulo 4 da dissertação), modelos estatísticos consagrados foram avaliados. Dentre as opções identificadas, o modelo probabilístico de Distribuição Binomial Negativa (Pascal) mostrou-se adequado para determinar o número mínimo de ciclos de limpeza que precisam ser realizados para que todos os tubos de um mesmo passe do trocador sejam visitados pelo menos uma vez, por uma das esferas abrasivas utilizadas no ciclo de limpeza do trocador. O estudo probabilístico realizado considerou o critério fundamentado no trabalho experimental de Müller-Steinhagen (2000), que recomenda utilizar um número máximo de artefatos de limpeza (em cada ciclo de limpeza), determinado como um percentual (30\%) do número de tubos por passe do trocador, visando evitar congestionamento dos artefatos no interior das 
chicanas do trocador. O modelo probabilístico clássico utilizado foi adaptado à realidade física do problema estudado ao incluir "penalidades probabilísticas", que reduzem a chance de um tubo ainda não visitado em um passe do trocador ser revisitado por outro artefato de limpeza no ciclo subsequente, já que este artefato, naturalmente, tende a seguir o caminho de menor resistência hidrodinâmica (um tubo já visitado por uma esfera elimina parte da incrustação, o que reduz a perda de carga imposta ao escoamento neste tubo). Do ponto de vista matemático, deferentes níveis de penalidade (entre 0 e 80 \%) foram aplicadas no parâmetro $p$ da Binomial Negativa (probabilidade $p$ no primeiro ciclo e $p$ ' nos ciclos subsequentes). Como conclusão do estudo foi determinado, para cada nível de penalidade aplicada, o total de ciclos de limpeza requerido para que todos os tubos do trocador de calor sejam visitados pelo menos uma vez por um artefato de limpeza. O resultado desse estudo probabilístico mostrou-se decisivo para orientar a programação do sistema de automação do dispositivo de limpeza.

Já no que concerne ao objetivo específico relacionado à proposição de parâmetros metrológicos críticos para fundamentar a validação metrológica em laboratório do dispositivo de limpeza (discutidos no Capítulo 5 da dissertação), uma detalhada análise de incertezas foi realizada para avaliar a confiabilidade metrológica do sistema embarcado no dispositivo de limpeza SIREA 3. A utilização desse sistema de medição embarcado permitiu, também, mapear a perda de carga imposta em cada tramo do equipamento de limpeza, assim orientando a reconstrução de componentes críticos do equipamento em sua configuração original. As melhorias incrementais no projeto construtivo do dispositivo de limpeza, notadamente nas câmaras de injeção e recuperação (caracterizadas no Capítulo 6) contribuíram para a otimização hidrodinâmica do circuito hidráulico do dispositivo de limpeza (e.g.: eliminação de expansões bruscas, suavização dos desvios de fluxo, sincronização de válvulas de abertura e fechamento do escoamento para evitar golpes de aríete). Essas modificações resultaram em ganhos de funcionalidade e expressiva redução dos custos de bombeamento.

Conclui-se, assim, que os objetivos originalmente concebidos foram integralmente atingidos e que as modificações implantadas no dispositivo de limpeza por esferas abrasivas contribuíram para agregar ganhos econômicos e operacionais ao equipamento concebido. 


\section{2 \\ Recomendações para desdobramentos futuros}

Avaliar o sistema de limpeza validado em laboratório em um trocador de calor em operação em uma planta industrial. Embora o dispositivo de limpeza esteja operacional e pronto para ser acoplado a um trocador de processo industrial, as restrições do isolamento social imposto pela pandemia do coronavírus não permitiram viabilizar o seu acoplamento a um trocador em operação real. Por essa razão, a validação limitou-se ao seu acoplamento a um trocador de calor construído com tubos de acrílico, que permitiu avaliar não apenas características de sua funcionalidade, mas, também, visualizar a eficácia da livre circulação das esferas abrasivas pelos tubos, porém sem o efeito de incrustações. Nesse sentido, recomenda-se uma rodada de ensaios com o dispositivo de limpeza SIREA 3 acoplado a um trocador de calor de um processo industrial. Duas alternativas foram consideradas, planejadas e autorizadas, embora não realizadas: (i) acoplamento a um trocador de calor de pequeno porte (trocador do tipo casco e tubo, com 40 tubos de $16 \mathrm{~mm}$ de diâmetro interno, $1 \mathrm{~m}$ de comprimento, ensaiados com vazão de $40 \mathrm{~m} 3 / \mathrm{h}$ ) em operação na indústria Maroni Ltda. de injeção de plásticos e (ii) trocador de grande porte do tipo feixe de tubos paralelos, escoamento cruzado, do sistema de refrigeração de um dos hidrogeradores da usina Fontes Nova, de propriedade da Light Energia S/A (75 tubos de $23 \mathrm{~mm}$ de diâmetro interno, $2 \mathrm{~m}$ de comprimento, ensaiados com vazão de $40 \mathrm{~m}^{3} / \mathrm{h}$ ).

No que concerne à investigação relacionada ao cálculo de probabilidade que define o número mínimo de ciclos de limpeza, recomenda-se sofisticar o modelo probabilístico utilizado. Acredita-se que um modelo mais robusto, fundamentado em estatística bayesiana, seja capaz de atribuir penalidades distintas a cada tubo de um mesmo passe para modelar a redução de resistência hidrodinâmica nos tubos já visitados do passe. Ao contrário do presente estudo que atribuiu penalidades iguais a todos os tubos do passe, a sofisticação proposta via estatística Bayesiana promete um estudo probabilístico mais representativo do problema físico existente associado ao complexo escoamento que oferece alternativas probabilísticas distintas de percursos a serem perseguidas pelos artefatos de limpeza. 


\section{7 \\ Referências bibliográficas}

ABD-ELHADY, M. S.; MALAYERI, M. R. Impact of hardness and surface texture on cleaning action of various projectiles. Chemical Engineering Research and Design, v. 94, p. 153-163, February $20152015 . \quad$ DOI: 10.1016/j.cherd.2014.07.022.

BARBOSA, C. R. H, NUNES, J. R. C.; GERMANO, S. B.; FROTA, M. N.; VALENTE, G. Sistema Optoeletrônico na Faixa do Infravermelho para Contagem de Esferas em Meios Turvos. In: Anais do 9 Congresso Brasileiro de Metrologia. 2017. Anais... Fortaleza: Gran Mareiro Hotel, 27 de novembro de 2017.

BERGMAN, T. L.; LAVINE, A. S.; INCROPERA, F.P.; DEWITT, D.P.; Fundamentos de Transferência de Calor e de Massa, 7a edição, LTC - Livros Técnicos e Científicos Editora S. A., R. J., 2016.

BOLSTAD, W. M. Introduction to Bayesian Statistics. $1^{\text {st }}$ ed. John Wiley \& Sons, Inc., 2007.

BOTT, T. R. Aspects of crystallization fouling. Experimental thermal and fluid science, v.14, n.4, p.356-360, 1997.

BOTT, T. R. Fouling of heat exchangers and its mitigation with special reference to biofouling. In: 2nd European Thermal Science UTI National Heat Transfer Conference, 1996, Rome. Proceedings of the 2nd European Thermal Science UTI National Heat Transfer Conference. Rome: UIT, 1996, vol 1, pp 115-125.

BOTT, T. R., MELO, L.F. Fouling of heat exchangers. Experimental thermal and fluid science, v.14, n.4, p.315, 1997.

BOTT, T.R. Heat Exchanger Cleaning. In: Fouling of Heat Exchangers. 1. ed. Birmingham: Elsevier B.V., 1995. p.357-407.

BOTT, T.R. Heat Exchanger Cleaning. In: Fouling of Heat Exchangers. 1. ed. Birmingham: Elsevier B.V., 1995. p.413.

BRAGA, S.L., FROTA, M.N., MILON, J.J., TICONA, E.M., NETO, J.R.C.A. Hydrodynamic and thermal evaluation of fouling mitigation in hydro generators heat exchangers. In: 8th International Conference on Heat Transfer, Fluid Mechanics and Thermodynamics, 2011, Point Aux Piments, Mauritius Island. (2011. Proceedings of the 8th International Conference on Heat Transfer, Fluid Mechanics and Thermodynamics). June 26 $6^{\text {th }}-J u l y 1^{\text {st }}, 2011$.

CHAUVENET, W. Manual of Spherical and Practical Astronomy - vol. II: Theory and Use of Astronomical Instruments. Londres: Trübner \& CO, 1868. Filadélfia: J. B. Lippincott \& CO, 1868.

CONOVER, W. J. Practical nonparametric statistics. New York: Wiley 1971. $462 p$. 
DANCOR S.A. Catálogo geral de produtos 2014. Disponível em: <http://www.dancor.com.br/dancor-site-novo/public/uploads/catalogo_geral/catal ogo_geraleral-2014.pdf>. Acesso em: 14 jan. 19.

de OLIVEIRA, E. C.; de FARO ORLANDO, A.; dos SANTOS FERREIRA, A. L.; de OLIVEIRA CHAVES, C. E. Comparison of different approaches for detection and treatment of outliers in meter proving factors determination. Flow Measurement and Instrumentation, v.48, p.29-35, 2016.

de OLIVEIRA, K. C. Projeto e desenvolvimento de um sistema opto eletrônico para contagem automática de esferas abrasivas mitigadoras de incrustações em trocadores de calor. Rio de Janeiro, 2016, 45 p. Trabalho de Graduação (Graduação em Mecânica). Pontifícia Universidade Católica do Rio de Janeiro.

FOX, R. W.; McDONALD, A. T.; PRITCHARD, P. J. Introdução à Mecânica dos Fluidos. $8^{\mathrm{a}}$ ed. Rio de Janeiro: LTC, 2016.

Frota M.N.; BARBOSA C.R. H.; Germano S.B.; Valente. G. Jr. Cabeça de série de um sistema inovador de limpeza de trocadores de calor de hidrogeradores. In: anais do 10ํㅡㄹ Congresso de Inovação Tecnológica e Eficiência Energética no Setor Elétrico (CITENEL). 2019. Anais... Campinas: outubro de 2019.

FROTA, M. N., TICONA, E. M., NEVES, A. V., Marques, R. P., Braga, S. L., \& Valente, G. On-line cleaning technique for mitigation of biofouling in heat exchangers: A case study of a hydroelectric power plant in brazil. Experimental Thermal and Fluid Science, v.53, p.197-206, 2014. DOI: 10.1016/j.expthermflusci.2013.12.006

FROTA, M.N., OLIVEIRA, V. H., TICONA, J.M., VALENTE, G. O papel da qualidade da água em trocadores de calor: estudo de caso em sistemas de arrefecimento de hidrogeradores. In: Congresso 2014 RESAG-Enqualab. 2014. Anais... São Paulo: Associação Brasileira da Indústria de Máquinas e Equipamentos - ABIMAQ, 29 a 31 de outubro de 2014.

HITACHI Ltd. Isao Okouchi; Sankichi Takahashi; Yasuteru Mukai; Katsumoto Otake; Takuya Sasaki; Masahiko Miyai. Cleaning System for Heat Conductive Condults of a Heat Exchanger. EUA n. US4420038 13 de dezembro de 1983.

INMETRO, Calibração de transdutor/ transmissor de pressão - Guia de calibração. Rio de Janeiro, 2010.

ISO GUM 2008, Avaliação de dados de Medição - Guia para a expressão de incerteza de medição. $1^{\underline{a}}$ ed. Rio de Janeiro, 2012.

JALALIRAD, M. R.; ABD-ELHADY, M. S.; MALAYERI, M. R. Cleaning action of spherical projectiles in tubular heat exchangers. International Journal of Heat and Mass Transfer, v. 57, n. 2, p. 491-499, 2// 2013. ISSN 0017-9310. Disponível em: < http://www.sciencedirect.com/science/article/pii/S001793101200837X >.

KRAFT, C. H.; EEDEN, Constance van. A nonparametric introduction to statistics. New York: MacMillan, 1968.

KRISHNAIAH, P. R.; SEN, P. K. Nonparametric Methods. Amsterdam: NorthHolland, 1984. 968p.: ISBN 0444 868712: (enc). 
KSB SE \& Co. Cavitação em bombas centrífugas. 2015. Disponível em: $<$ https://www.ksb.com/ksb-pt/Informacoes_tecnicas-noticias_ch/Arquivo/ 2015info-tecnicas-e-noticias/cavitacao-em-bombas-centrifugas/177256/>. Acesso em: 02 dez. 18.

LUBICZ, S. B. Projeto e desenvolvimento de contador de esferas abrasivas em meios turvos. Rio de Janeiro, 2016, 50 p. Trabalho de Graduação (Graduação em Mecânica). Pontifícia Universidade Católica do Rio de Janeiro.

MAPLES, M. P.; REICHART, D. E.; Konz, N. C.; BERGER, T. A.; TROTTER, A. S.; MARTIN, J. R.; SALEMI, C. P. Robust chauvenet outlier rejection. The Astrophysical Journal Supplement Series, v.238, n.2, p.49, 2018.

MÜLLER-STEINHAGEN, H. M. Handbook of Heat Exchanger Fouling:Mitigation and cleaning technologies. 2000. ISBN 0852954360. Disponível em:<https://books.google.com.br/books/about/Handbook_of_ Heat_Exchanger_Fouling.html?hl=pt-BR\&id=e5ah-CL-0q4C >.Disponível em: <http://www.scopus.com/inward/record.url?eid=2-s2.0-33847101049\&partnerlD= $40 \& \mathrm{md} 5=3 c 7352 \mathrm{~b} 0 \mathrm{ff} 5 \mathrm{~b} 2 \mathrm{c} 0873 \mathrm{ffe} 59123252$ cc9 > . Acesso em 03 dez. 20.

MÜLLER-STEINHAGEN, H.; MALAYERI, M. R.; WATKINSON, A. P. Recent advances in heat exchanger fouling research, mitigation, and cleaning techniques. Heat Transfer Engineering, v. 28, n. 3, p. 173-176, 2007. Disponível em:<http://www.scopus.com/inward/record.url?eid=2-s2.033847101049\&partnerl $\mathrm{D}=40 \& \mathrm{md5}=3 \mathrm{c} 7352 \mathrm{~b} 0 \mathrm{ff5} b 2 \mathrm{c0873ffe} 59123252$ cc9 > .

NEVES, A. V. Mitigação de incrustação em trocadores de calor de hidrogeradores: estudo de caso da usina Fontes Nova. Rio de Janeiro, 2013, 118 p. Dissertação (Mestrado) - Programa de Pós-Graduação em Metrologia. Pontifícia Universidade Católica do Rio de Janeiro.

NUNES, J. R. C. Dispositivo optoeletrônico na faixa do infravermelho para detecção e medição de velocidade de esferas utilizadas como artefatos de limpeza de trocadores de calor. Rio de Janeiro, 2018, 89 p. Dissertação (Mestrado) - Programa de Pós-Graduação em Metrologia. Pontifícia Universidade Católica do Rio de Janeiro.

OLIVEIRA, V. H. Alternativa tecnológica para monitoramento e mitigação de incrustação em trocadores de calor pela circulação de esferas abrasivas. 2015. 90 p. Dissertação (Mestrado em Metrologia). Departamento de Pós-Graduação em Metrologia, Pontifícia Universidade Católica do Rio de Janeiro, Rio de Janeiro.

OLIVEIRA, V. H.; FROTA, M. N.; VALENTE, G. Estudo do comportamento de esferas abrasivas usadas como artefatos de limpeza de trocadores de calor. In: Anais do 9ํㅡㄹ Congresso Brasileiro de Metrologia. 2017. Anais... Fortaleza: Gran Mareiro Hotel, 27 de novembro de 2017.

PACHECO, E.R.C. Controle metrológico em tempo real do desempenho térmico de trocadores de calor de hidrogeradores. Rio de Janeiro, 2020, 104 p. Dissertação (Mestrado em Metrologia). Departamento de Pós-Graduação em Metrologia, Pontifícia Universidade Católica do Rio de Janeiro, Rio de Janeiro. 
PAIXÃO, C. M. Automação de uma alternativa tecnológica concebida para realizar a limpeza de trocadores de calor por esferas abrasivas. Rio de Janeiro, 2017, 41 p. Trabalho de Graduação (Graduação em Mecânica). Pontifícia Universidade Católica do Rio de Janeiro.

Relatório Técnico. FROTA, M. N, VALENTE, G. J. Relatório final do Projeto de P\&D Light-Aneel Ref.: 5161-010/2016 - Cabeça de Série de um sistema inovador de limpeza de trocadores de calor de hidrogeradores. Rio de Janeiro: PUC-Rio, 2018. 144p. Relatório Técnico.

Relatório Técnico. FROTA, M. N. Relatório final P\&D Light-Aneel Ref.: 07/2011 Proposição de solução inovadora para o sistema de resfriamento dos hidrogeradores da Usina Fontes Nova. Rio de Janeiro: PUC-Rio, 2014. 84p. Relatório Técnico.

Relatório Técnico. FROTA, M. N. Relatório final P\&D OKE06-07, Tecnologia de Tratamento de Água de Refrigeração da Usina Fontes Nova, P\&D Light Energia, Ciclo 2006-2007. Rio de Janeiro: PUC-Rio, 2007. Relatório Técnico.

Relatório Técnico. FROTA, M.N.; BARBOSA C.R.H.; NUNES, J. R. C.; Rios, J.L. Relatório Técnico no: 14/2018 - Calibração de comprimentos optoeletrônicos ("distâncias efetivas") medidos pelo Contador de Esferas (CONDE) Rio de Janeiro: PUC-Rio, 2018. 21p. Relatório Técnico do Projeto de P\&D Light/Aneel 5161010/2016.

Relatório Técnico. OLIVEIRA, V. H.; RIOS, J. L. R.; FROTA, M. N. Relatório Temático no.: 03/2016, P\&D LIGHT/ANEEL 010/2016 - Subsídios técnicos para projeto e construção de esferas abrasivas. Rio de Janeiro: PUC-Rio, 2016. 19p. Relatório Técnico.

RIOS, J. L. R. Dispositivo servo-hidráulico para introdução e recuperação de partículas em escoamentos internos de interesse industrial. 2017. p155. Trabalho de Conclusão de Curso (Graduação em Engenharia Mecânica). Departamento de Graduação em Engenharia Mecânica, Pontifícia Universidade Católica do Rio de Janeiro, Rio de Janeiro.

RIOS, J. L. R.; FROTA, M. N.; GERMANO, S. B. Sistema inteligente para ablução de trocadores de calor. In: Anais do 9o Congresso Brasileiro de Metrologia. 2017. Anais... Fortaleza: Gran Mareiro Hotel, 27 de novembro de 2017.

TAPROGGE. Josef Taprogge. Self-Cleaning Heat - Exchanger. EUA n. US3021117 A, 13 de fevereiro de 1962.

VERGARA, S.C. Metodologia do trabalho científico. 22ํㅡㄹ ed. São Paulo: Cortez. 2002.

ZIHAO, Z.; LINGLI, Z.; WANG, Y. Outlier removal based on Chauvenet's criterion and dense disparity refinement using least square support vector machine. Journal of Electronic Imaging, v.28, n.023028, 2019. 


\section{Apêndice A: Estudo para determinação do número de ciclos de limpeza}

Estudo de número de ciclos necessários para garantir que todos os tubos do trocador de calor sejam visitados ao menos uma vez por pelo menos uma esfera.

Neste apêndice são apresentados os dados dos estudos realizados para determinação do número de ciclos necessários para garantir que ao menos uma vez todos os tubos do trocador de calor sejam visitados por uma esfera. As condições que delimitam o alcance deste estudo estão especificadas no Capítulo 4.

Os dados apresentados nas tabelas, a seguir, foram obtidos por meio da função "DIST.BIN.NEG.N"- Distribuição Binomial Negativa- utilizando o software Excel. 
Tabela 16 - Número de ciclos sem aplicação de penalidade

\begin{tabular}{|c|c|c|c|}
\hline $\begin{array}{l}\text { № de } \\
\text { ciclos } \\
\end{array}$ & $p$ & $\begin{array}{c}\text { Probabilidade } \\
\text { Calculada }\end{array}$ & $\begin{array}{c}\text { Probabilidade } \\
\text { Acumulada }\end{array}$ \\
\hline 4 & 0,308 & $0,90 \%$ & $0,9 \%$ \\
\hline 5 & & $2,48 \%$ & $3,4 \%$ \\
\hline 6 & & $4,30 \%$ & $7,7 \%$ \\
\hline 7 & & $5,95 \%$ & $13,6 \%$ \\
\hline 8 & & $7,21 \%$ & $20,8 \%$ \\
\hline 9 & & $7,98 \%$ & $28,8 \%$ \\
\hline 10 & . & $8,29 \%$ & $37,1 \%$ \\
\hline 11 & . & $8,20 \%$ & $45,3 \%$ \\
\hline 12 & . & $7,80 \%$ & $53,1 \%$ \\
\hline 13 & & $7,20 \%$ & $60,3 \%$ \\
\hline 14 & & $6,48 \%$ & $66,8 \%$ \\
\hline 15 & & $5,71 \%$ & $72,5 \%$ \\
\hline 16 & & $4,94 \%$ & $77,4 \%$ \\
\hline 17 & & $4,21 \%$ & $81,7 \%$ \\
\hline 18 & & $3,54 \%$ & $85,2 \%$ \\
\hline 19 & & $2,94 \%$ & $88,1 \%$ \\
\hline 20 & & $2,42 \%$ & $90,6 \%$ \\
\hline 21 & . & $1,97 \%$ & $92,5 \%$ \\
\hline 22 & . & $1,59 \%$ & $94,1 \%$ \\
\hline 23 & . & $1,28 \%$ & $95,4 \%$ \\
\hline 24 & & $1,02 \%$ & $96,4 \%$ \\
\hline 25 & & $0,80 \%$ & $97,2 \%$ \\
\hline 26 & & $0,63 \%$ & $97,9 \%$ \\
\hline 27 & & $0,49 \%$ & $98,3 \%$ \\
\hline 28 & & $0,39 \%$ & $98,7 \%$ \\
\hline 29 & & $0,30 \%$ & $99,0 \%$ \\
\hline 30 & & $0,23 \%$ & $99,3 \%$ \\
\hline 31 & & $0,18 \%$ & $99,4 \%$ \\
\hline 32 & . & $0,14 \%$ & $99,6 \%$ \\
\hline 33 & . & $0,10 \%$ & $99,7 \%$ \\
\hline 34 & . & $0,08 \%$ & $99,8 \%$ \\
\hline 35 & & $0,06 \%$ & $99,8 \%$ \\
\hline 36 & & $0,05 \%$ & $99,9 \%$ \\
\hline 37 & & $0,03 \%$ & $99,9 \%$ \\
\hline 38 & & $0,03 \%$ & $99,9 \%$ \\
\hline 39 & & $0,02 \%$ & $99,9 \%$ \\
\hline 40 & & $0,01 \%$ & $100,0 \%$ \\
\hline
\end{tabular}

Tabela 17 - Número de ciclos com aplicação de penalidade de $10 \%$

\begin{tabular}{|c|c|c|c|}
\hline $\begin{array}{l}\text { № de } \\
\text { ciclos }\end{array}$ & $p$ & $\begin{array}{c}\text { Probabilidade } \\
\text { Calculada }\end{array}$ & $\begin{array}{c}\text { Probabilidade } \\
\text { Acumulada }\end{array}$ \\
\hline 4 & 0,308 & $0,9 \%$ & $0,9 \%$ \\
\hline 5 & 0,277 & $1,7 \%$ & $2,6 \%$ \\
\hline 6 & & $3,1 \%$ & $5,7 \%$ \\
\hline 7 & & $4,4 \%$ & $10,1 \%$ \\
\hline 8 & & $5,6 \%$ & $15,7 \%$ \\
\hline 9 & & $6,5 \%$ & $22,3 \%$ \\
\hline 10 & . & $7,1 \%$ & $29,3 \%$ \\
\hline 11 & . & $7,3 \%$ & $36,6 \%$ \\
\hline 12 & . & $7,3 \%$ & $43,9 \%$ \\
\hline 13 & & $7,0 \%$ & $50,8 \%$ \\
\hline 14 & & $6,6 \%$ & $57,4 \%$ \\
\hline 15 & & $6,0 \%$ & $63,5 \%$ \\
\hline 16 & & $5,5 \%$ & $68,9 \%$ \\
\hline 17 & & $4,9 \%$ & $73,8 \%$ \\
\hline 18 & & $4,3 \%$ & $78,1 \%$ \\
\hline 19 & & $3,7 \%$ & $81,8 \%$ \\
\hline 20 & & $3,2 \%$ & $85,0 \%$ \\
\hline 21 & . & $2,7 \%$ & $87,7 \%$ \\
\hline 22 & . & $2,3 \%$ & $89,9 \%$ \\
\hline 23 & . & $1,9 \%$ & $91,9 \%$ \\
\hline 24 & & $1,6 \%$ & $93,4 \%$ \\
\hline 25 & & $1,3 \%$ & $94,8 \%$ \\
\hline 26 & & $1,1 \%$ & $95,8 \%$ \\
\hline 27 & & $0,9 \%$ & $96,7 \%$ \\
\hline 28 & & $0,7 \%$ & $97,4 \%$ \\
\hline 29 & & $0,6 \%$ & $98,0 \%$ \\
\hline 30 & & $0,5 \%$ & $98,5 \%$ \\
\hline 31 & & $0,4 \%$ & $98,9 \%$ \\
\hline 32 & . & $0,3 \%$ & $99,2 \%$ \\
\hline 33 & . & $0,2 \%$ & $99,4 \%$ \\
\hline 34 & . & $0,2 \%$ & $99,6 \%$ \\
\hline 35 & & $0,2 \%$ & $99,8 \%$ \\
\hline 36 & & $0,1 \%$ & $99,9 \%$ \\
\hline 37 & & $0,1 \%$ & $100,0 \%$ \\
\hline
\end{tabular}


Tabela 18 - Número de ciclos com aplicação de penalidade de $20 \%$

\begin{tabular}{|c|c|c|c|}
\hline $\begin{array}{l}\text { № de } \\
\text { ciclos }\end{array}$ & $p$ & $\begin{array}{c}\text { Probabilidade } \\
\text { Calculada }\end{array}$ & $\begin{array}{c}\text { Probabilidade } \\
\text { Acumulada }\end{array}$ \\
\hline 4 & 0,308 & $0,9 \%$ & $0,9 \%$ \\
\hline 5 & 0,246 & $1,1 \%$ & $2,0 \%$ \\
\hline 6 & & $2,1 \%$ & $4,1 \%$ \\
\hline 7 & & $3,1 \%$ & $7,2 \%$ \\
\hline 8 & & $4,1 \%$ & $11,4 \%$ \\
\hline 9 & & $5,0 \%$ & $16,4 \%$ \\
\hline 10 & . & $5,7 \%$ & $22,1 \%$ \\
\hline 11 & . & $6,1 \%$ & $28,1 \%$ \\
\hline 12 & . & $6,3 \%$ & $34,5 \%$ \\
\hline 13 & & $6,4 \%$ & $40,8 \%$ \\
\hline 14 & & $6,2 \%$ & $47,0 \%$ \\
\hline 15 & & $6,0 \%$ & $53,0 \%$ \\
\hline 16 & & $5,6 \%$ & $58,6 \%$ \\
\hline 17 & & $5,2 \%$ & $63,9 \%$ \\
\hline 18 & & $4,8 \%$ & $68,6 \%$ \\
\hline 19 & & $4,3 \%$ & $73,0 \%$ \\
\hline 20 & & $3,9 \%$ & $76,8 \%$ \\
\hline 21 & . & $3,4 \%$ & $80,3 \%$ \\
\hline 22 & . & $3,0 \%$ & $83,3 \%$ \\
\hline 23 & . & $2,6 \%$ & $85,9 \%$ \\
\hline 24 & & $2,3 \%$ & $88,2 \%$ \\
\hline 25 & & $2,0 \%$ & $90,2 \%$ \\
\hline 26 & & $1,7 \%$ & $91,8 \%$ \\
\hline 27 & & $1,4 \%$ & $93,3 \%$ \\
\hline 28 & & $1,2 \%$ & $94,5 \%$ \\
\hline 29 & & $1,0 \%$ & $95,5 \%$ \\
\hline 30 & & $0,9 \%$ & $96,4 \%$ \\
\hline 31 & & $0,7 \%$ & $97,1 \%$ \\
\hline 32 & . & $0,6 \%$ & $97,7 \%$ \\
\hline 33 & . & $0,5 \%$ & $98,2 \%$ \\
\hline 34 & . & $0,4 \%$ & $98,6 \%$ \\
\hline 35 & & $0,3 \%$ & $99,0 \%$ \\
\hline 36 & & $0,3 \%$ & $99,3 \%$ \\
\hline 37 & & $0,2 \%$ & $99,5 \%$ \\
\hline 38 & & $0,2 \%$ & $99,7 \%$ \\
\hline 39 & & $0,2 \%$ & $99,9 \%$ \\
\hline 40 & & $0,1 \%$ & $100,0 \%$ \\
\hline
\end{tabular}

Tabela 19 - Número de ciclos com aplicação de penalidade de $30 \%$

\begin{tabular}{|c|c|c|c|}
\hline $\begin{array}{l}N \text { de } \\
\text { ciclos }\end{array}$ & $p$ & $\begin{array}{c}\text { Probabilidade } \\
\text { Calculada }\end{array}$ & $\begin{array}{c}\text { Probabilidade } \\
\text { Acumulada }\end{array}$ \\
\hline 4 & 0,308 & $0,9 \%$ & $0,9 \%$ \\
\hline 5 & 0,215 & $0,7 \%$ & $1,6 \%$ \\
\hline 6 & & $1,3 \%$ & $2,9 \%$ \\
\hline 7 & & $2,1 \%$ & $5,0 \%$ \\
\hline 8 & & $2,9 \%$ & $7,8 \%$ \\
\hline 9 & & $3,6 \%$ & $11,4 \%$ \\
\hline 10 & . & $4,2 \%$ & $15,6 \%$ \\
\hline 11 & . & $4,7 \%$ & $20,4 \%$ \\
\hline 12 & . & $5,1 \%$ & $25,5 \%$ \\
\hline 13 & & $5,3 \%$ & $30,8 \%$ \\
\hline 14 & & $5,4 \%$ & $36,2 \%$ \\
\hline 15 & & $5,4 \%$ & $41,7 \%$ \\
\hline 16 & & $5,3 \%$ & $47,0 \%$ \\
\hline 17 & & $5,1 \%$ & $52,2 \%$ \\
\hline 18 & & $4,9 \%$ & $57,1 \%$ \\
\hline 19 & & $4,6 \%$ & $61,7 \%$ \\
\hline 20 & & $4,3 \%$ & $66,0 \%$ \\
\hline 21 & . & $4,0 \%$ & $69,9 \%$ \\
\hline 22 & . & $3,6 \%$ & $73,6 \%$ \\
\hline 23 & . & $3,3 \%$ & $76,9 \%$ \\
\hline 24 & & $3,0 \%$ & $79,9 \%$ \\
\hline 25 & & $2,7 \%$ & $82,5 \%$ \\
\hline 26 & & $2,4 \%$ & $84,9 \%$ \\
\hline 27 & & $2,1 \%$ & $87,0 \%$ \\
\hline 28 & & $1,9 \%$ & $88,9 \%$ \\
\hline 29 & & $1,6 \%$ & $90,5 \%$ \\
\hline 30 & & $1,4 \%$ & $92,0 \%$ \\
\hline 31 & & $1,3 \%$ & $93,2 \%$ \\
\hline 32 & . & $1,1 \%$ & $94,3 \%$ \\
\hline 33 & . & $0,9 \%$ & $95,2 \%$ \\
\hline 34 & . & $0,8 \%$ & $96,1 \%$ \\
\hline 35 & & $0,7 \%$ & $96,8 \%$ \\
\hline 36 & & $0,6 \%$ & $97,4 \%$ \\
\hline 37 & & $0,5 \%$ & $97,9 \%$ \\
\hline 38 & & $0,4 \%$ & $98,3 \%$ \\
\hline 39 & & $0,4 \%$ & $98,7 \%$ \\
\hline 40 & & $0,3 \%$ & $99,0 \%$ \\
\hline 41 & & $0,3 \%$ & $99,3 \%$ \\
\hline 42 & & $0,2 \%$ & $99,5 \%$ \\
\hline 43 & & $0,2 \%$ & $99,7 \%$ \\
\hline 44 & & $0,2 \%$ & $99,9 \%$ \\
\hline 45 & & $0,1 \%$ & $100,0 \%$ \\
\hline
\end{tabular}

Tabela 20 - Número de ciclos com aplicação de penalidade de $40 \%$

\begin{tabular}{|c|c|c|c|c|c|c|c|}
\hline $\begin{array}{l}\text { № de } \\
\text { ciclos }\end{array}$ & $p$ & $\begin{array}{l}\text { Probabilidade } \\
\text { Calculada }\end{array}$ & $\begin{array}{l}\text { Probabilidade } \\
\text { Acumulada }\end{array}$ & $\begin{array}{l}\text { № de } \\
\text { ciclos }\end{array}$ & $p$ & $\begin{array}{c}\text { Probabilidade } \\
\text { Calculada }\end{array}$ & $\begin{array}{c}\text { Probabilidade } \\
\text { Acumulada }\end{array}$ \\
\hline 4 & 0,308 & $0,9 \%$ & $0,9 \%$ & 46 & 0,215 & $0,3 \%$ & $98,8 \%$ \\
\hline 5 & 0,215 & $0,7 \%$ & $1,6 \%$ & 47 & & $0,3 \%$ & $99,0 \%$ \\
\hline 6 & & $1,3 \%$ & $2,9 \%$ & 48 & & $0,2 \%$ & $99,3 \%$ \\
\hline 7 & & $2,1 \%$ & $5,0 \%$ & 49 & & $0,2 \%$ & $99,5 \%$ \\
\hline 8 & & $2,9 \%$ & $7,8 \%$ & 50 & & $0,2 \%$ & $99,7 \%$ \\
\hline 9 & & $3,6 \%$ & $11,4 \%$ & 51 & & $0,2 \%$ & $99,8 \%$ \\
\hline 10 & . & $4,2 \%$ & $15,6 \%$ & 52 & & $0,1 \%$ & $100,0 \%$ \\
\hline 11 & . & $4,7 \%$ & $20,4 \%$ & & & & \\
\hline 12 & . & $5,1 \%$ & $25,5 \%$ & & & & \\
\hline 13 & & $5,3 \%$ & $30,8 \%$ & & & & \\
\hline 14 & & $5,4 \%$ & $36,2 \%$ & & & & \\
\hline 15 & & $5,4 \%$ & $41,7 \%$ & & & & \\
\hline 16 & & $5,3 \%$ & $47,0 \%$ & & & & \\
\hline 17 & & $5,1 \%$ & $52,2 \%$ & & & & \\
\hline 18 & & $4,9 \%$ & $57,1 \%$ & & & & \\
\hline 19 & & $4,6 \%$ & $61,7 \%$ & & & & \\
\hline 20 & & $4,3 \%$ & $66,0 \%$ & & & & \\
\hline 21 & . & $4,0 \%$ & $69,9 \%$ & & & & \\
\hline 22 & . & $3,6 \%$ & $73,6 \%$ & & & & \\
\hline 23 & . & $3,3 \%$ & $76,9 \%$ & & & & \\
\hline 24 & & $3,0 \%$ & $79,9 \%$ & & & & \\
\hline 25 & & $2,7 \%$ & $82,5 \%$ & & & & \\
\hline 26 & & $2,4 \%$ & $84,9 \%$ & & & & \\
\hline 27 & & $2,1 \%$ & $87,0 \%$ & & & & \\
\hline 28 & & $1,9 \%$ & $88,9 \%$ & & & & \\
\hline
\end{tabular}




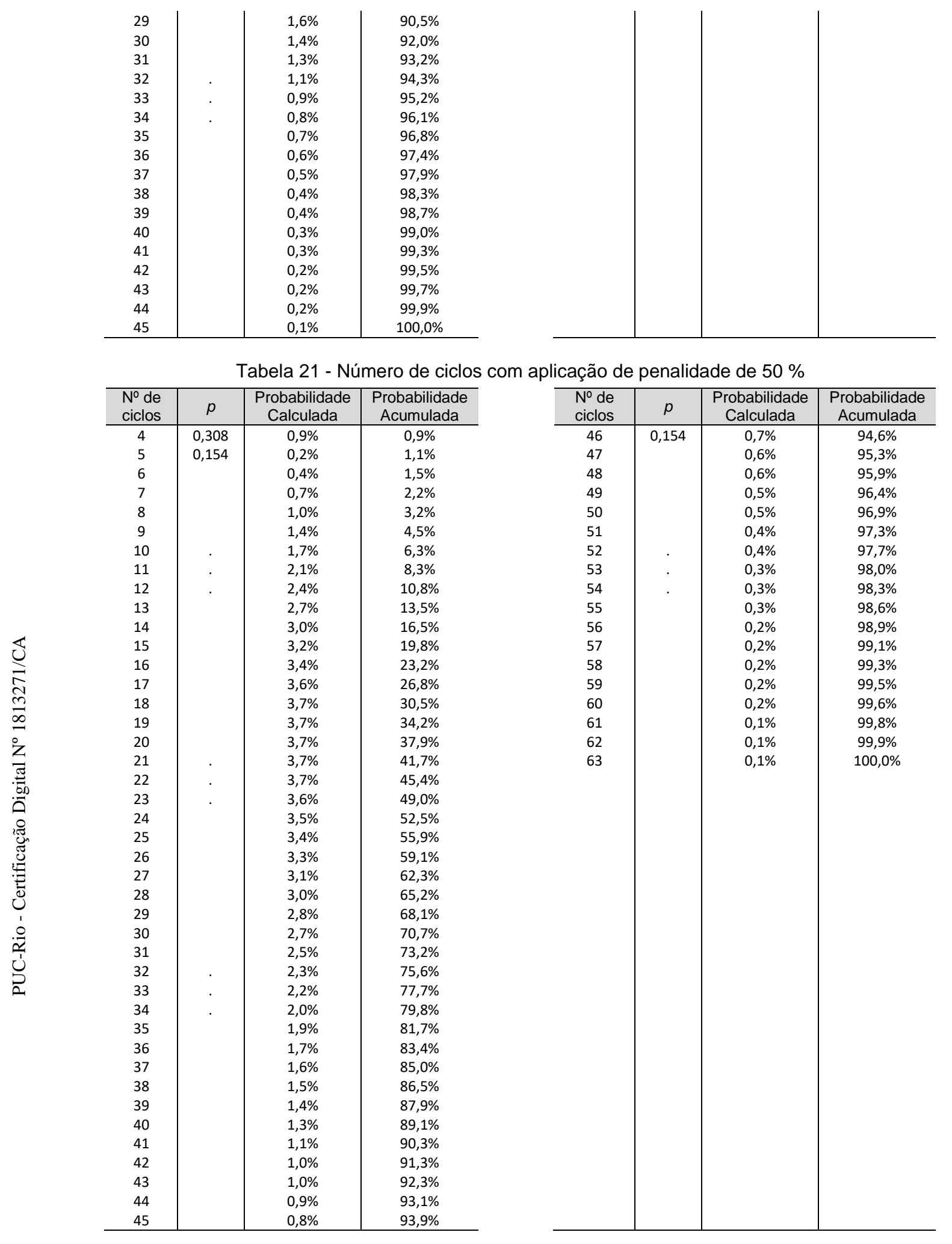


Tabela 22 - Número de ciclos com aplicação de penalidade de $60 \%$

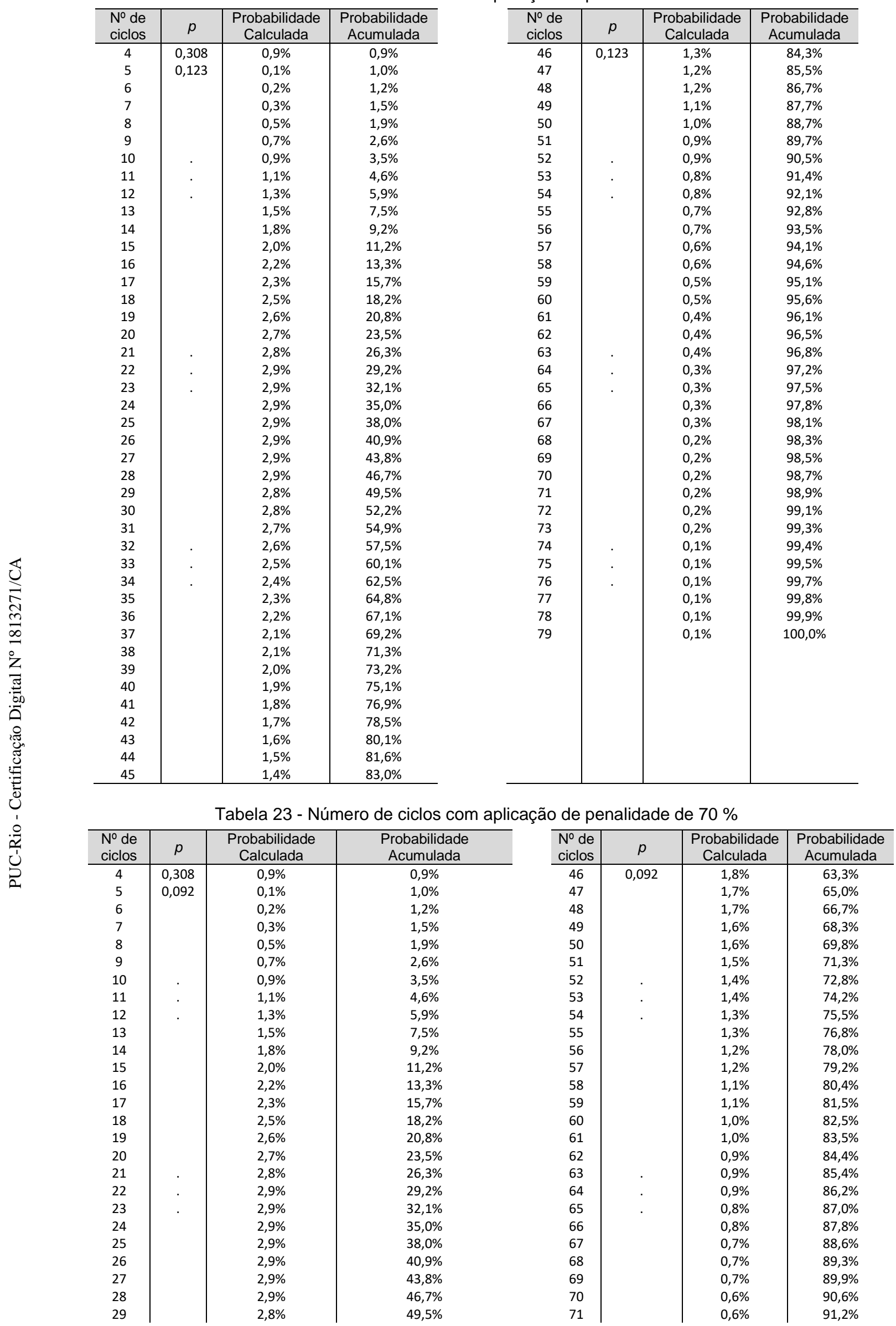




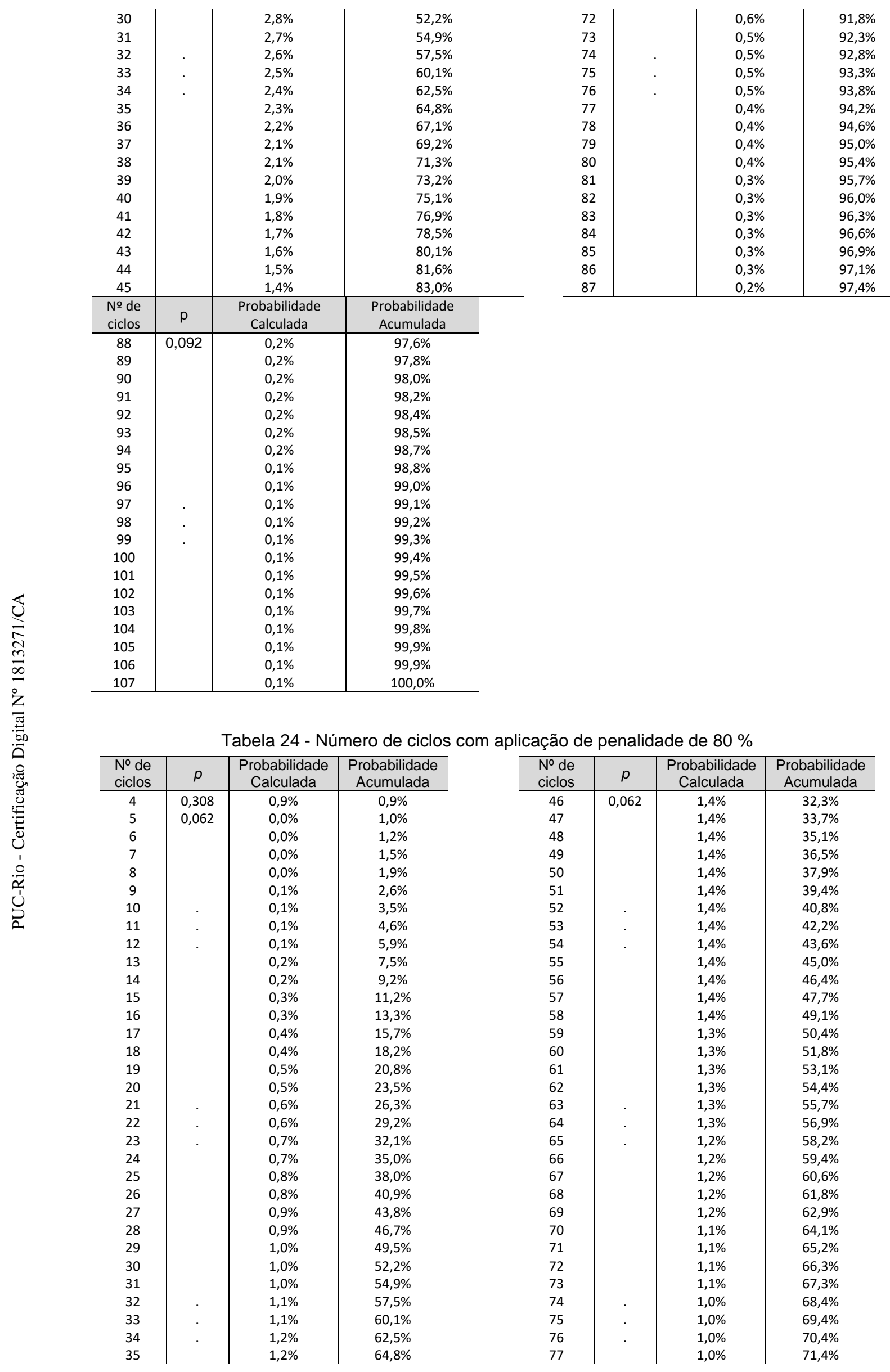




\begin{tabular}{|c|c|c|c|}
\hline 36 & & $1,2 \%$ & $67,1 \%$ \\
\hline 37 & & $1,3 \%$ & $69,2 \%$ \\
\hline 38 & & $1,3 \%$ & $71,3 \%$ \\
\hline 39 & & $1,3 \%$ & $73,2 \%$ \\
\hline 40 & & $1,3 \%$ & $75,1 \%$ \\
\hline 41 & & $1,4 \%$ & $76,9 \%$ \\
\hline 42 & & $1,4 \%$ & $78,5 \%$ \\
\hline 43 & & $1,4 \%$ & $80,1 \%$ \\
\hline 44 & & $1,4 \%$ & $81,6 \%$ \\
\hline 45 & & $1,4 \%$ & $83,0 \%$ \\
\hline $\begin{array}{l}\text { № de } \\
\text { ciclos }\end{array}$ & $p$ & $\begin{array}{c}\text { Probabilidade } \\
\text { Calculada }\end{array}$ & $\begin{array}{c}\text { Probabilidade } \\
\text { Acumulada }\end{array}$ \\
\hline 88 & 0,062 & $0,7 \%$ & $80,6 \%$ \\
\hline 89 & & $0,7 \%$ & $81,4 \%$ \\
\hline 90 & & $0,7 \%$ & $82,0 \%$ \\
\hline 91 & & $0,7 \%$ & $82,7 \%$ \\
\hline 92 & & $0,7 \%$ & $83,4 \%$ \\
\hline 93 & & $0,6 \%$ & $84,0 \%$ \\
\hline 94 & & $0,6 \%$ & $84,6 \%$ \\
\hline 95 & & $0,6 \%$ & $85,2 \%$ \\
\hline 96 & & $0,6 \%$ & $85,8 \%$ \\
\hline 97 & & $0,6 \%$ & $86,3 \%$ \\
\hline 98 & & $0,5 \%$ & $86,9 \%$ \\
\hline 99 & & $0,5 \%$ & $87,4 \%$ \\
\hline 100 & & $0,5 \%$ & $87,9 \%$ \\
\hline 101 & & $0,5 \%$ & $88,4 \%$ \\
\hline 102 & & $0,5 \%$ & $88,9 \%$ \\
\hline 103 & & $0,5 \%$ & $89,3 \%$ \\
\hline 104 & & $0,4 \%$ & $89,8 \%$ \\
\hline 105 & & $0,4 \%$ & $90,2 \%$ \\
\hline 106 & & $0,4 \%$ & $90,6 \%$ \\
\hline 107 & & $0,4 \%$ & $91,0 \%$ \\
\hline 108 & & $0,4 \%$ & $91,4 \%$ \\
\hline 109 & & $0,4 \%$ & $91,8 \%$ \\
\hline 110 & & $0,4 \%$ & $92,1 \%$ \\
\hline 111 & & $0,3 \%$ & $92,5 \%$ \\
\hline 112 & & $0,3 \%$ & $92,8 \%$ \\
\hline 113 & & $0,3 \%$ & $93,1 \%$ \\
\hline 114 & & $0,3 \%$ & $93,4 \%$ \\
\hline 115 & & $0,3 \%$ & $93,7 \%$ \\
\hline 116 & & $0,3 \%$ & $94,0 \%$ \\
\hline 117 & & $0,3 \%$ & $94,3 \%$ \\
\hline 118 & & $0,3 \%$ & $94,6 \%$ \\
\hline 119 & & $0,3 \%$ & $94,8 \%$ \\
\hline 120 & & $0,2 \%$ & $95,1 \%$ \\
\hline 121 & & $0,2 \%$ & $95,3 \%$ \\
\hline 122 & & $0,2 \%$ & $95,5 \%$ \\
\hline 123 & & $0,2 \%$ & $95,8 \%$ \\
\hline 124 & & $0,2 \%$ & $96,0 \%$ \\
\hline 125 & & $0,2 \%$ & $96,2 \%$ \\
\hline 126 & & $0,2 \%$ & $96,4 \%$ \\
\hline 127 & & $0,2 \%$ & $96,6 \%$ \\
\hline 128 & & $0,2 \%$ & $96,8 \%$ \\
\hline 129 & & $0,2 \%$ & $96,9 \%$ \\
\hline
\end{tabular}

\begin{tabular}{l|l|l|l}
78 & $1,0 \%$ & $72,3 \%$ \\
79 & & $0,9 \%$ & $73,3 \%$ \\
80 & & $0,9 \%$ & $74,2 \%$ \\
81 & & $0,9 \%$ & $75,1 \%$ \\
82 & $0,9 \%$ & $75,9 \%$ \\
83 & $0,8 \%$ & $76,8 \%$ \\
84 & & $0,8 \%$ & $77,6 \%$ \\
85 & & $0,8 \%$ & $78,4 \%$ \\
86 & $0,8 \%$ & $79,2 \%$ \\
87 & $0,8 \%$ & $79,9 \%$ \\
\hline
\end{tabular}

\begin{tabular}{|c|c|c|c|}
\hline $\begin{array}{l}\text { № de } \\
\text { ciclos }\end{array}$ & $p$ & $\begin{array}{c}\text { Probabilidade } \\
\text { Calculada } \\
\end{array}$ & $\begin{array}{c}\text { Probabilidade } \\
\text { Acumulada }\end{array}$ \\
\hline 130 & \multirow[t]{32}{*}{0,062} & $0,2 \%$ & $97,1 \%$ \\
\hline 131 & & $0,2 \%$ & $97,3 \%$ \\
\hline 132 & & $0,2 \%$ & $97,4 \%$ \\
\hline 133 & & $0,1 \%$ & $97,6 \%$ \\
\hline 134 & & $0,1 \%$ & $97,7 \%$ \\
\hline 135 & & $0,1 \%$ & $97,8 \%$ \\
\hline 136 & & $0,1 \%$ & $98,0 \%$ \\
\hline 137 & & $0,1 \%$ & $98,1 \%$ \\
\hline 138 & & $0,1 \%$ & $98,2 \%$ \\
\hline 139 & & $0,1 \%$ & $98,3 \%$ \\
\hline 140 & & $0,1 \%$ & $98,4 \%$ \\
\hline 141 & & $0,1 \%$ & $98,6 \%$ \\
\hline 142 & & $0,1 \%$ & $98,7 \%$ \\
\hline 143 & & $0,1 \%$ & $98,8 \%$ \\
\hline 144 & & $0,1 \%$ & $98,8 \%$ \\
\hline 145 & & $0,1 \%$ & $98,9 \%$ \\
\hline 146 & & $0,1 \%$ & $99,0 \%$ \\
\hline 147 & & $0,1 \%$ & $99,1 \%$ \\
\hline 148 & & $0,1 \%$ & $99,2 \%$ \\
\hline 149 & & $0,1 \%$ & $99,3 \%$ \\
\hline 150 & & $0,1 \%$ & $99,3 \%$ \\
\hline 151 & & $0,1 \%$ & $99,4 \%$ \\
\hline 152 & & $0,1 \%$ & $99,5 \%$ \\
\hline 153 & & $0,1 \%$ & $99,5 \%$ \\
\hline 154 & & $0,1 \%$ & $99,6 \%$ \\
\hline 155 & & $0,1 \%$ & $99,7 \%$ \\
\hline 156 & & $0,1 \%$ & $99,7 \%$ \\
\hline 157 & & $0,1 \%$ & $99,8 \%$ \\
\hline 158 & & $0,1 \%$ & $99,8 \%$ \\
\hline 159 & & $0,0 \%$ & $99,9 \%$ \\
\hline 160 & & $0,0 \%$ & $99,9 \%$ \\
\hline 161 & & $0,0 \%$ & $100,0 \%$ \\
\hline & & & \\
\hline & & & \\
\hline & & & \\
\hline & & & \\
\hline & & & \\
\hline
\end{tabular}




\section{Apêndice B: Calibração do contador de esferas}

O Apêndice B apresenta os dados referentes à calibração do CONDE Duplo para determinação do diâmetro efetivo e distância efetiva (espaçamento efetivo) entre os planos de medição.

Tabela 25 - Valores obtidos na medição de Def1 pelo procedimento de calibração

\begin{tabular}{|c|c|c|c|c|c|c|c|}
\hline \multicolumn{8}{|c|}{$\begin{array}{c}\text { Plano de medição 01: } \\
\text { Tabela com todos os valores medidos (Inclui possíveis outliers) }\end{array}$} \\
\hline Medições & $\begin{array}{c}\mathrm{L} \text { - iminência de } \\
\text { desativação do } \\
\text { sensor óptico } \\
\text { (mm) }\end{array}$ & $\begin{array}{c}{ }^{*} \mathrm{~L} \\
(\mathrm{~mm})\end{array}$ & Valor de $r$ & Po & Área & Valor Crítico & Outlier \\
\hline 1 & 24,46 & 24,46 & 0,49 & 0,017 & 0,992 & 2,39 & Não \\
\hline 2 & 24,47 & 24,47 & 1,20 & 0,017 & 0,992 & 2,39 & Não \\
\hline 3 & 24,46 & 24,46 & 0,49 & 0,017 & 0,992 & 2,39 & Não \\
\hline 4 & 24,45 & 24,45 & 0,21 & 0,017 & 0,992 & 2,39 & Não \\
\hline 5 & 24,46 & 24,46 & 0,49 & 0,017 & 0,992 & 2,39 & Não \\
\hline 6 & 24,47 & 24,47 & 1,20 & 0,017 & 0,992 & 2,39 & Não \\
\hline 7 & 24,47 & 24,47 & 1,20 & 0,017 & 0,992 & 2,39 & Não \\
\hline 8 & 24,48 & 24,48 & 1,90 & 0,017 & 0,992 & 2,39 & Não \\
\hline 9 & 24,46 & 24,46 & 0,49 & 0,017 & 0,992 & 2,39 & Não \\
\hline 10 & 24,48 & 24,48 & 1,90 & 0,017 & 0,992 & 2,39 & Não \\
\hline 11 & 24,46 & 24,46 & 0,49 & 0,017 & 0,992 & 2,39 & Não \\
\hline 12 & 24,46 & 24,46 & 0,49 & 0,017 & 0,992 & 2,39 & Não \\
\hline 13 & 24,46 & 24,46 & 0,49 & 0,017 & 0,992 & 2,39 & Não \\
\hline 14 & 24,46 & 24,46 & 0,49 & 0,017 & 0,992 & 2,39 & Não \\
\hline 15 & 24,45 & 24,45 & 0,21 & 0,017 & 0,992 & 2,39 & Não \\
\hline 16 & 24,45 & 24,45 & 0,21 & 0,017 & 0,992 & 2,39 & Não \\
\hline 17 & 24,46 & 24,46 & 0,49 & 0,017 & 0,992 & 2,39 & Não \\
\hline 18 & 24,46 & 24,46 & 0,49 & 0,017 & 0,992 & 2,39 & Não \\
\hline 19 & 24,44 & 24,44 & 0,92 & 0,017 & 0,992 & 2,39 & Não \\
\hline 20 & 24,44 & 24,44 & 0,92 & 0,017 & 0,992 & 2,39 & Não \\
\hline 21 & 24,44 & 24,44 & 0,92 & 0,017 & 0,992 & 2,39 & Não \\
\hline 22 & 24,44 & 24,44 & 0,92 & 0,017 & 0,992 & 2,39 & Não \\
\hline 23 & 24,44 & 24,44 & 0,92 & 0,017 & 0,992 & 2,39 & Não \\
\hline 24 & 24,43 & 24,43 & 1,62 & 0,017 & 0,992 & 2,39 & Não \\
\hline 25 & 24,43 & 24,43 & 1,62 & 0,017 & 0,992 & 2,39 & Não \\
\hline 26 & 24,44 & 24,44 & 0,92 & 0,017 & 0,992 & 2,39 & Não \\
\hline 27 & 24,43 & 24,43 & 1,62 & 0,017 & 0,992 & 2,39 & Não \\
\hline 28 & 24,44 & 24,44 & 0,92 & 0,017 & 0,992 & 2,39 & Não \\
\hline 29 & 24,44 & 24,44 & 0,92 & 0,017 & 0,992 & 2,39 & Não \\
\hline 30 & 24,46 & 24,46 & 0,49 & 0,017 & 0,992 & 2,39 & Não \\
\hline
\end{tabular}

${ }^{*}$ Ajuste do zero

Cuidados foram tomados para eliminar o efeito da folga existente no parafuso sem fim (power screw), que aciona o travessão da INSTRON; i.e.: cuidados foram tomados para que este sempre retornasse à mesma posição inicial antes de se iniciar uma nova medição.

Tabela 26 - Valores obtidos na medição de Def2 pelo procedimento de calibração

\begin{tabular}{|c|c|c|c|c|c|c|c|}
\hline \multicolumn{8}{|c|}{$\begin{array}{l}\text { Plano de medição 02: } \\
\text { Tabela com todos valores medidos (Inclui possiveis outliers) }\end{array}$} \\
\hline Medições & $\begin{array}{c}\mathrm{L} \text { - iminência de } \\
\text { desativação do } \\
\text { sensor óptico } \\
(\mathrm{mm})\end{array}$ & $\begin{array}{c}{ }^{*} \mathrm{~L} \\
(\mathrm{~mm})\end{array}$ & Valor de $r$ & Po & Área & Valor Crítico & Outlier \\
\hline 1 & 22,58 & 22,58 & 0,96 & 0,017 & 0,992 & 2,39 & Não \\
\hline 2 & 22,58 & 22,58 & 0,96 & 0,017 & 0,992 & 2,39 & Não \\
\hline 3 & 22,59 & 22,59 & 0,47 & 0,017 & 0,992 & 2,39 & Não \\
\hline 4 & 22,59 & 22,59 & 0,47 & 0,017 & 0,992 & 2,39 & Não \\
\hline 5 & 22,59 & 22,59 & 0,47 & 0,017 & 0,992 & 2,39 & Não \\
\hline 6 & 22,60 & 22,60 & 0,02 & 0,017 & 0,992 & 2,39 & Não \\
\hline 7 & 22,58 & 22,58 & 0,96 & 0,017 & 0,992 & 2,39 & Não \\
\hline 8 & 22,59 & 22,59 & 0,47 & 0,017 & 0,992 & 2,39 & Não \\
\hline 9 & 22,60 & 22,60 & 0,02 & 0,017 & 0,992 & 2,39 & Não \\
\hline 10 & 22,59 & 22,59 & 0,47 & 0,017 & 0,992 & 2,39 & Não \\
\hline 11 & 22,57 & 22,57 & 1,44 & 0,017 & 0,992 & 2,39 & Não \\
\hline
\end{tabular}




\begin{tabular}{|c|c|c|c|c|c|c|c|}
\hline 12 & 22,60 & 22,60 & 0,02 & 0,017 & 0,992 & 2,39 & Não \\
\hline 13 & 22,61 & 22,61 & 0,50 & 0,017 & 0,992 & 2,39 & Não \\
\hline 14 & 22,59 & 22,59 & 0,47 & 0,017 & 0,992 & 2,39 & Não \\
\hline 15 & 22,59 & 22,59 & 0,47 & 0,017 & 0,992 & 2,39 & Não \\
\hline 16 & 22,60 & 22,60 & 0,02 & 0,017 & 0,992 & 2,39 & Não \\
\hline 17 & 22,59 & 22,59 & 0,47 & 0,017 & 0,992 & 2,39 & Não \\
\hline 18 & 22,60 & 22,60 & 0,02 & 0,017 & 0,992 & 2,39 & Não \\
\hline 19 & 22,60 & 22,60 & 0,02 & 0,017 & 0,992 & 2,39 & Não \\
\hline 20 & 22,61 & 22,61 & 0,50 & 0,017 & 0,992 & 2,39 & Não \\
\hline 21 & 22,60 & 22,60 & 0,02 & 0,017 & 0,992 & 2,39 & Não \\
\hline 22 & 22,57 & 22,57 & 1,44 & 0,017 & 0,992 & 2,39 & Não \\
\hline 23 & 22,57 & 22,57 & 1,44 & 0,017 & 0,992 & 2,39 & Não \\
\hline 24 & 22,60 & 22,60 & 0,02 & 0,017 & 0,992 & 2,39 & Não \\
\hline 25 & 22,61 & 22,61 & 0,50 & 0,017 & 0,992 & 2,39 & Não \\
\hline 26 & 22,63 & 22,63 & 1,47 & 0,017 & 0,992 & 2,39 & Não \\
\hline 27 & 22,64 & 22,64 & 1,96 & 0,017 & 0,992 & 2,39 & Não \\
\hline 28 & 22,64 & 22,64 & 1,96 & 0,017 & 0,992 & 2,39 & Não \\
\hline 29 & 22,64 & 22,64 & 1,96 & 0,017 & 0,992 & 2,39 & Não \\
\hline 30 & 22,64 & 22,64 & 1,96 & 0,017 & 0,992 & 2,39 & Não \\
\hline
\end{tabular}

\begin{abstract}
*Ajuste do zero
Cuidados foram tomados para eliminar o efeito da folga existente no parafuso sem fim (power screw), que aciona o travessão da INSTRON; i.e.: cuidados foram tomados para que este sempre retornasse à mesma posição inicial antes de se iniciar uma nova medição.
\end{abstract}

Tabela 27 - Valores obtidos de LEF pelo procedimento de calibração

\begin{tabular}{|c|c|c|c|c|c|c|c|}
\hline \multicolumn{8}{|c|}{$\begin{array}{l}\text { Distância entre Planos de Medição } 01 \text { e 02: } \\
\text { Tabela com todos valores medidos (Inclui possíveis outliers) }\end{array}$} \\
\hline Medições & $\begin{array}{l}\text { LEF - espaçamento } \\
\text { entre planos de } \\
\text { medição } \\
(\mathrm{mm})\end{array}$ & $\begin{array}{c}{ }^{*} \mathrm{~L} \\
(\mathrm{~mm})\end{array}$ & Valor de $r$ & Po & Área & Valor Crítico & Outlier \\
\hline 1 & 49,28 & 49,28 & 0,98 & 0,017 & 0,992 & 2,39 & Não \\
\hline 2 & 49,28 & 49,28 & 0,98 & 0,017 & 0,992 & 2,39 & Não \\
\hline 3 & 49,28 & 49,28 & 0,98 & 0,017 & 0,992 & 2,39 & Não \\
\hline 4 & 49,28 & 49,28 & 0,98 & 0,017 & 0,992 & 2,39 & Não \\
\hline 5 & 49,28 & 49,28 & 0,98 & 0,017 & 0,992 & 2,39 & Não \\
\hline 6 & 49,28 & 49,28 & 0,98 & 0,017 & 0,992 & 2,39 & Não \\
\hline 7 & 49,28 & 49,28 & 0,98 & 0,017 & 0,992 & 2,39 & Não \\
\hline 8 & 49,28 & 49,28 & 0,98 & 0,017 & 0,992 & 2,39 & Não \\
\hline 9 & 49,28 & 49,28 & 0,98 & 0,017 & 0,992 & 2,39 & Não \\
\hline 10 & 49,28 & 49,28 & 0,98 & 0,017 & 0,992 & 2,39 & Não \\
\hline 11 & 49,28 & 49,28 & 0,98 & 0,017 & 0,992 & 2,39 & Não \\
\hline 12 & 49,28 & 49,28 & 0,98 & 0,017 & 0,992 & 2,39 & Não \\
\hline 13 & 49,28 & 49,28 & 0,98 & 0,017 & 0,992 & 2,39 & Não \\
\hline 14 & 49,28 & 49,28 & 0,98 & 0,017 & 0,992 & 2,39 & Não \\
\hline 15 & 49,28 & 49,28 & 0,98 & 0,017 & 0,992 & 2,39 & Não \\
\hline 16 & 49,28 & 49,28 & 0,98 & 0,017 & 0,992 & 2,39 & Não \\
\hline 17 & 49,28 & 49,28 & 0,98 & 0,017 & 0,992 & 2,39 & Não \\
\hline 18 & 49,28 & 49,28 & 0,98 & 0,017 & 0,992 & 2,39 & Não \\
\hline 19 & 49,28 & 49,28 & 0,98 & 0,017 & 0,992 & 2,39 & Não \\
\hline 20 & 49,28 & 49,28 & 0,98 & 0,017 & 0,992 & 2,39 & Não \\
\hline 21 & 49,28 & 49,28 & 0,98 & 0,017 & 0,992 & 2,39 & Não \\
\hline 22 & 49,28 & 49,28 & 0,98 & 0,017 & 0,992 & 2,39 & Não \\
\hline 23 & 49,28 & 49,28 & 0,98 & 0,017 & 0,992 & 2,39 & Não \\
\hline 24 & 49,28 & 49,28 & 0,98 & 0,017 & 0,992 & 2,39 & Não \\
\hline 25 & 49,28 & 49,28 & 0,98 & 0,017 & 0,992 & 2,39 & Não \\
\hline 26 & 49,28 & 49,28 & 0,98 & 0,017 & 0,992 & 2,39 & Não \\
\hline 27 & 49,28 & 49,28 & 0,98 & 0,017 & 0,992 & 2,39 & Não \\
\hline 28 & 49,28 & 49,28 & 0,98 & 0,017 & 0,992 & 2,39 & Não \\
\hline 29 & 49,28 & 49,28 & 0,98 & 0,017 & 0,992 & 2,39 & Não \\
\hline 30 & 49,28 & 49,28 & 0,98 & 0,017 & 0,992 & 2,39 & Não \\
\hline
\end{tabular}

${ }^{*}$ Ajuste do zero

Cuidados foram tomados para eliminar o efeito da folga existente no parafuso sem fim (power screw), que aciona o travessão da INSTRON; i.e.: cuidados foram tomados para que este sempre retornasse à mesma posição inicial antes de se iniciar uma nova medição. 


\section{Apêndice C: Calibração do subsistema de vazão do dispositivo SIREA 3}

Neste apêndice são apresentados os resultados das medições de calibração dos medidores de vazão que foram utilizados ao longo do processo de melhoria do dispositivo de limpeza de trocadores de calor (SIREA 3). Cada um dos instrumentos utilizados encontra-se devidamente caracterizado no corpo do capítulo 5 da dissertação. A título de ilustração, apenas os resultados das medições de calibração realizada com o grupo motor-bomba operando na frequência de $50 \mathrm{~Hz}$ foram incluídos na sua totalidade, assim ilustrando o tamanho e a estrutura da base de dados. Por limitação de espaço, apenas extratos da base de dados completa dos dados da calibração realizada nas demais frequências (60 $\mathrm{Hz}, 55 \mathrm{~Hz}, 45 \mathrm{~Hz}, 40 \mathrm{~Hz}, 35 \mathrm{~Hz}$ e $30 \mathrm{~Hz}$ ) foram documentados neste apêndice.

Os resultados de medições de vazão associados ao processo de calibração destacados em vermelho representam os valores outliers que foram eliminados em conformidade ao critério Chauvenet, fundamentado na teoria detalhada no capítulo 5. Os procedimentos de cálculo dos parâmetros $r$ e do valor crítico para definir se o dado reflete ou não um outlier (que deve eliminado da base de dados) está descrito nas equações 18, 19, 20 e 21, do capítulo 5 .

Os dados apresentados nas tabelas, a seguir, foram obtidos de maneira experimental e seguindo todos as orientações de boas práticas de calibração de instrumentos de medição. 
Tabela 28 - Dados obtidos com o rotor da bomba hidráulica girando na frequência de $60 \mathrm{~Hz}$

\begin{tabular}{|c|c|c|c|c|c|c|c|c|c|c|c|}
\hline \multicolumn{12}{|c|}{$\begin{array}{l}\text { Dados obtidos na frequência de } 60 \mathrm{~Hz} \text { : } \\
\text { Tabela com todos valores medidos (Inclui possíveis outliers) }\end{array}$} \\
\hline Medições & $\begin{array}{l}\text { Qpadrão } \\
\mathrm{m}^{3} / \mathrm{h}\end{array}$ & $\begin{array}{l}\text { QIFM } \\
\mathrm{m}^{3} / \mathrm{h}\end{array}$ & $\begin{array}{c}\text { Qvectus } \\
\mathrm{m}^{3} / \mathrm{h}\end{array}$ & Medições & $\begin{array}{c}\text { Qpadrão } \\
\mathrm{m}^{3} / \mathrm{h}\end{array}$ & $\begin{array}{l}\text { QIFM } \\
\mathrm{m}^{3} / \mathrm{h}\end{array}$ & $\begin{array}{c}\text { Qvectus } \\
\mathrm{m}^{3} / \mathrm{h}\end{array}$ & Medições & $\begin{array}{c}\text { Qpadrão } \\
\mathrm{m}^{3} / \mathrm{h}\end{array}$ & $\begin{array}{l}\text { QIFM } \\
m^{3} / h\end{array}$ & $\begin{array}{l}\text { Qvectus } \\
\mathrm{m}^{3} / \mathrm{h}\end{array}$ \\
\hline 1 & 13,262 & 13,30 & 12,27 & 21 & 13,243 & 13,27 & 12,36 & 41 & 13,269 & 13,26 & 12,38 \\
\hline 2 & 13,254 & 13,30 & 12,28 & 22 & 13,234 & 12,85 & 12,36 & 42 & 13,268 & 12,86 & 12,38 \\
\hline 3 & 13,237 & 13,30 & 12,29 & 23 & 13,233 & 13,26 & 12,36 & 43 & 13,265 & 12,86 & 12,38 \\
\hline 4 & 13,226 & 13,29 & 12,30 & 24 & 13,23 & 12,85 & 12,36 & 44 & 13,252 & 12,86 & 12,38 \\
\hline 5 & 13,217 & 13,29 & 12,30 & 25 & 13,226 & 12,85 & 12,37 & 45 & 13,245 & 13,26 & 12,38 \\
\hline 6 & 13,212 & 13,29 & 12,30 & 26 & 13,228 & 13,26 & 12,37 & 46 & 13,241 & 13,26 & 12,38 \\
\hline 7 & 13,206 & 13,28 & 12,30 & 27 & 13,231 & 13,26 & 12,37 & 47 & 13,24 & 12,86 & 12,39 \\
\hline 8 & 13,208 & 13,28 & 12,30 & 28 & 13,233 & 12,85 & 12,37 & 48 & 13,233 & 12,86 & 12,39 \\
\hline 9 & 13,211 & 13,28 & 12,30 & 29 & 13,239 & 13,26 & 12,37 & 49 & 13,218 & 12,86 & 12,39 \\
\hline 10 & 13,216 & 12,83 & 12,32 & 30 & 13,237 & 12,85 & 12,37 & 50 & 13,207 & 12,86 & 12,39 \\
\hline 11 & 13,225 & 13,28 & 12,33 & 31 & 13,234 & 12,86 & 12,37 & 51 & 13,193 & 12,86 & 12,39 \\
\hline 12 & 13,227 & 12,84 & 12,34 & 32 & 13,233 & 12,86 & 12,37 & 52 & 13,186 & 12,86 & 12,39 \\
\hline 13 & 13,225 & 13,28 & 12,34 & 33 & 13,23 & 12,86 & 12,37 & 53 & 13,189 & 12,86 & 12,40 \\
\hline 14 & 13,223 & 12,84 & 12,34 & 34 & 13,227 & 12,86 & 12,37 & 54 & 13,206 & 12,86 & 12,40 \\
\hline 15 & 13,229 & 13,27 & 12,35 & 35 & 13,222 & 12,86 & 12,37 & 55 & 13,212 & 12,86 & 12,40 \\
\hline 16 & 13,231 & 12,85 & 12,35 & 36 & 13,227 & 13,26 & 12,37 & 56 & 13,212 & 12,86 & 12,40 \\
\hline 17 & 13,234 & 12,85 & 12,36 & 37 & 13,231 & 12,86 & 12,38 & 57 & 13,212 & 12,86 & 12,40 \\
\hline 18 & 13,239 & 12,85 & 12,36 & 38 & 13,237 & 12,86 & 12,38 & 58 & 13,219 & 13,25 & 12,40 \\
\hline 19 & 13,245 & 12,85 & 12,36 & 39 & 13,248 & 12,86 & 12,38 & 59 & 13,229 & 12,86 & 12,40 \\
\hline 20 & 13,248 & 13,27 & 12,36 & 40 & 13,259 & 12,86 & 12,38 & 60 & 13,24 & 12,86 & 12,40 \\
\hline$:$ & : & $:$ & $:$ & : & $:$ & : & $:$ & : & : & $:$ & $:$ \\
\hline$:$ & : & : & : & : & : & : & : & : & : & : & : \\
\hline : & : & : & : & : & : & : & : & : & : & : & : \\
\hline : & : & $:$ & : & : & : & $:$ & $:$ & : & $:$ & : & $:$ \\
\hline : & : & $:$ & : & : & : & $:$ & : & : & $:$ & : & : \\
\hline 1940 & 12,877 & 13,06 & 13,36 & 1968 & 12,863 & 13,06 & 13,37 & 1996 & 12,858 & 13,06 & 13,39 \\
\hline 1941 & 12,879 & 13,06 & 13,36 & 1969 & 12,86 & 13,06 & 13,41 & 1997 & 12,862 & 13,06 & 13,38 \\
\hline 1942 & 12,879 & 13,05 & 13,41 & 1970 & 12,862 & 13,06 & 13,41 & 1998 & 12,872 & 13,06 & 13,39 \\
\hline 1943 & 12,875 & 13,05 & 13,36 & 1971 & 12,863 & 13,06 & 13,37 & 1999 & 12,885 & 13,06 & 13,38 \\
\hline 1944 & 12,871 & 13,05 & 13,36 & 1972 & 12,87 & 13,06 & 13,40 & 2000 & 12,899 & 13,06 & 13,38 \\
\hline 1945 & 12,871 & 13,05 & 13,36 & 1973 & 12,891 & 13,06 & 13,40 & 2001 & 12,912 & 13,06 & 13,39 \\
\hline 1946 & 12,869 & 13,05 & 13,36 & 1974 & 12,912 & 13,05 & 13,40 & 2002 & 12,905 & 13,06 & 13,38 \\
\hline 1947 & 12,867 & 13,05 & 13,36 & 1975 & 12,918 & 13,05 & 13,40 & 2003 & 12,893 & 13,06 & 13,38 \\
\hline 1948 & 12,871 & 13,06 & 13,41 & 1976 & 12,926 & 13,05 & 13,37 & 2004 & 12,867 & 13,06 & 13,39 \\
\hline 1949 & 12,879 & 13,06 & 13,41 & 1977 & 12,931 & 13,06 & 13,40 & 2005 & 12,851 & 13,06 & 13,39 \\
\hline 1950 & 12,889 & 13,06 & 13,41 & 1978 & 12,935 & 13,06 & 13,40 & 2006 & 12,844 & 13,06 & 13,38 \\
\hline 1951 & 12,894 & 13,06 & 13,36 & 1979 & 12,931 & 13,06 & 13,37 & 2007 & 12,835 & 13,06 & 13,38 \\
\hline 1952 & 12,892 & 13,06 & 13,36 & 1980 & 12,918 & 13,06 & 13,37 & 2008 & 12,837 & 13,06 & 13,38 \\
\hline 1953 & 12,89 & 13,06 & 13,36 & 1981 & 12,918 & 13,06 & 13,37 & 2009 & 12,848 & 13,06 & 13,39 \\
\hline 1954 & 12,894 & 13,06 & 13,41 & 1982 & 12,919 & 13,06 & 13,37 & 2010 & 12,859 & 13,06 & 13,39 \\
\hline 1955 & 12,891 & 13,06 & 13,36 & 1983 & 12,913 & 13,06 & 13,37 & 2011 & 12,862 & 13,06 & 13,39 \\
\hline 1956 & 12,89 & 13,06 & 13,36 & 1984 & 12,902 & 13,06 & 13,37 & 2012 & 12,861 & 13,06 & 13,39 \\
\hline 1957 & 12,9 & 13,06 & 13,36 & 1985 & 12,893 & 13,06 & 13,37 & 2013 & 12,859 & 13,06 & 13,39 \\
\hline 1958 & 12,907 & 13,06 & 13,41 & 1986 & 12,88 & 13,06 & 13,40 & 2014 & 12,861 & 13,06 & 13,38 \\
\hline 1959 & 12,915 & 13,06 & 13,41 & 1987 & 12,864 & 13,06 & 13,40 & 2015 & 12,858 & 13,06 & 13,38 \\
\hline 1960 & 12,916 & 13,05 & 13,41 & 1988 & 12,864 & 13,06 & 13,40 & 2016 & 12,856 & 13,06 & 13,38 \\
\hline 1961 & 12,909 & 13,05 & 13,36 & 1989 & 12,866 & 13,06 & 13,40 & 2017 & 12,86 & 13,06 & 13,39 \\
\hline 1962 & 12,899 & 13,05 & 13,36 & 1990 & 12,856 & 13,06 & 13,40 & 2018 & 12,861 & 13,06 & 13,39 \\
\hline 1963 & 12,888 & 13,05 & 13,36 & 1991 & 12,847 & 13,05 & 13,40 & 2019 & 12,862 & 13,06 & 13,39 \\
\hline 1964 & 12,877 & 13,05 & 13,37 & 1992 & 12,848 & 13,05 & 13,40 & 2020 & 12,861 & 13,06 & 13,39 \\
\hline 1965 & 12,877 & 13,05 & 13,41 & 1993 & 12,857 & 13,05 & 13,38 & 2021 & 12,874 & 13,06 & 13,39 \\
\hline 1966 & 12,876 & 13,06 & 13,37 & 1994 & 12,859 & 13,05 & 13,38 & 2022 & 12,883 & 13,06 & 13,39 \\
\hline 1967 & 12,869 & 13,06 & 13,37 & 1995 & 12,858 & 13,05 & 13,39 & 2023 & 12,892 & 13,06 & 13,39 \\
\hline
\end{tabular}


Tabela 29 - Dados obtidos com o rotor da bomba hidráulica girando na frequência de $55 \mathrm{~Hz}$

\begin{tabular}{|c|c|c|c|c|c|c|c|c|c|c|c|}
\hline \multicolumn{12}{|c|}{$\begin{array}{c}\text { Dados obtidos na frequência de } 55 \mathrm{~Hz} \text { : } \\
\text { Tabela com todos valores medidos (Inclui possíveis outliers) }\end{array}$} \\
\hline Medições & $\begin{array}{c}\text { Qpadrão } \\
\mathrm{m}^{3} / \mathrm{h}\end{array}$ & $\begin{array}{l}\text { QIFM } \\
\mathrm{m}^{3} / \mathrm{h}\end{array}$ & $\begin{array}{c}\text { Qvectus } \\
\mathrm{m}^{3} / \mathrm{h}\end{array}$ & Medições & $\begin{array}{c}\text { Qpadrão } \\
\mathrm{m}^{3} / \mathrm{h}\end{array}$ & $\begin{array}{l}\text { QIFM } \\
\mathrm{m}^{3} / \mathrm{h}\end{array}$ & $\begin{array}{c}\text { Qvectus } \\
\mathrm{m}^{3} / \mathrm{h}\end{array}$ & Medições & $\begin{array}{c}\text { Qpadrão } \\
\mathrm{m}^{3} / \mathrm{h}\end{array}$ & $\begin{array}{l}\text { QIFM } \\
\mathrm{m}^{3} / \mathrm{h}\end{array}$ & $\begin{array}{c}\text { Qvectus } \\
\mathrm{m}^{3} / \mathrm{h}\end{array}$ \\
\hline 1 & 12,294 & 11,95 & 11,29 & 21 & 12,269 & 11,99 & 11,32 & 41 & 11,992 & 12,26 & 11,34 \\
\hline 2 & 12,294 & 11,96 & 11,29 & 22 & 12,267 & 11,99 & 11,32 & 42 & 12,254 & 12,00 & 11,35 \\
\hline 3 & 12,293 & 11,96 & 11,29 & 23 & 12,267 & 11,99 & 11,32 & 43 & 12,254 & 12,26 & 11,35 \\
\hline 4 & 12,285 & 11,97 & 11,29 & 24 & 12,267 & 12,27 & 11,33 & 44 & 12,253 & 12,00 & 11,35 \\
\hline 5 & 12,282 & 11,97 & 11,29 & 25 & 12,266 & 12,27 & 11,33 & 45 & 12,253 & 12,26 & 11,35 \\
\hline 6 & 12,281 & 12,28 & 11,29 & 26 & 12,264 & 12,27 & 11,33 & 46 & 12,253 & 12,26 & 11,35 \\
\hline 7 & 12,279 & 12,28 & 11,29 & 27 & 11,983 & 12,27 & 11,33 & 47 & 11,994 & 12,00 & 11,35 \\
\hline 8 & 12,279 & 11,98 & 11,29 & 28 & 12,262 & 12,27 & 11,33 & 48 & 11,994 & 12,00 & 11,35 \\
\hline 9 & 12,279 & 11,98 & 11,30 & 29 & 12,262 & 12,27 & 11,33 & 49 & 12,252 & 12,00 & 11,35 \\
\hline 10 & 12,278 & 12,28 & 11,30 & 30 & 12,261 & 12,27 & 11,33 & 50 & 12,252 & 12,00 & 11,35 \\
\hline 11 & 11,971 & 12,28 & 11,30 & 31 & 12,261 & 12,27 & 11,33 & 51 & 11,995 & 12,00 & 11,35 \\
\hline 12 & 12,274 & 12,28 & 11,30 & 32 & 11,987 & 12,27 & 11,33 & 52 & 12,251 & 12,26 & 11,36 \\
\hline 13 & 12,274 & 11,99 & 11,31 & 33 & 12,259 & 12,00 & 11,33 & 53 & 11,996 & 12,26 & 11,36 \\
\hline 14 & 11,973 & 11,99 & 11,31 & 34 & 12,259 & 12,26 & 11,33 & 54 & 12,25 & 12,26 & 11,36 \\
\hline 15 & 12,273 & 11,99 & 11,31 & 35 & 11,988 & 12,26 & 11,34 & 55 & 12,25 & 12,00 & 11,36 \\
\hline 16 & 12,272 & 11,99 & 11,32 & 36 & 11,988 & 12,26 & 11,34 & 56 & 12,25 & 12,26 & 11,37 \\
\hline 17 & 12,271 & 11,99 & 11,32 & 37 & 12,256 & 12,00 & 11,34 & 57 & 11,997 & 12,26 & 11,37 \\
\hline 18 & 11,976 & 12,27 & 11,32 & 38 & 12,256 & 12,26 & 11,34 & 58 & 11,997 & 12,26 & 11,38 \\
\hline 19 & 11,977 & 12,27 & 11,32 & 39 & 12,255 & 12,00 & 11,34 & 59 & 11,997 & 12,26 & 11,38 \\
\hline 20 & 12,269 & 12,27 & 11,32 & 40 & 12,255 & 12,26 & 11,34 & 60 & 11,997 & 12,01 & 11,39 \\
\hline$:$ & : & : & : & : & : & : & : & : & : & : & : \\
\hline : & : & : & : & : & : & : & : & : & : & : & : \\
\hline : & : & : & : & : & : & : & : & : & : & : & : \\
\hline 2079 & 12,127 & 12,13 & 12,62 & 2109 & 12,126 & 12,13 & 12,60 & 2139 & 12,125 & 12,13 & 12,61 \\
\hline 2080 & 12,127 & 12,13 & 12,62 & 2110 & 12,126 & 12,13 & 12,61 & 2140 & 12,125 & 12,13 & 12,61 \\
\hline 2081 & 12,127 & 12,13 & 12,60 & 2111 & 12,126 & 12,13 & 12,61 & 2141 & 12,125 & 12,13 & 12,61 \\
\hline 2082 & 12,127 & 12,13 & 12,62 & 2112 & 12,126 & 12,13 & 12,61 & 2142 & 12,125 & 12,13 & 12,61 \\
\hline 2083 & 12,127 & 12,13 & 12,62 & 2113 & 12,126 & 12,13 & 12,61 & 2143 & 12,125 & 12,13 & 12,61 \\
\hline 2084 & 12,127 & 12,13 & 12,62 & 2114 & 12,126 & 12,13 & 12,61 & 2144 & 12,125 & 12,13 & 12,61 \\
\hline 2085 & 12,127 & 12,13 & 12,62 & 2115 & 12,126 & 12,13 & 12,60 & 2145 & 12,125 & 12,13 & 12,61 \\
\hline 2086 & 12,127 & 12,13 & 12,62 & 2116 & 12,126 & 12,13 & 12,60 & 2146 & 12,125 & 12,13 & 12,61 \\
\hline 2087 & 12,127 & 12,13 & 12,62 & 2117 & 12,126 & 12,13 & 12,60 & 2147 & 12,125 & 12,13 & 12,61 \\
\hline 2088 & 12,127 & 12,13 & 12,60 & 2118 & 12,126 & 12,13 & 12,60 & 2148 & 12,122 & 12,13 & 12,61 \\
\hline 2089 & 12,127 & 12,13 & 12,60 & 2119 & 12,121 & 12,13 & 12,60 & 2149 & 12,122 & 12,13 & 12,61 \\
\hline 2090 & 12,12 & 12,13 & 12,62 & 2120 & 12,121 & 12,13 & 12,61 & 2150 & 12,122 & 12,13 & 12,61 \\
\hline 2091 & 12,12 & 12,13 & 12,62 & 2121 & 12,121 & 12,13 & 12,61 & 2151 & 12,122 & 12,13 & 12,61 \\
\hline 2092 & 12,12 & 12,13 & 12,62 & 2122 & 12,121 & 12,13 & 12,61 & 2152 & 12,122 & 12,13 & 12,61 \\
\hline 2093 & 12,12 & 12,13 & 12,62 & 2123 & 12,121 & 12,13 & 12,61 & 2153 & 12,122 & 12,13 & 12,61 \\
\hline 2094 & 12,12 & 12,13 & 12,62 & 2124 & 12,121 & 12,13 & 12,61 & 2154 & 12,122 & 12,13 & 12,61 \\
\hline 2095 & 12,12 & 12,13 & 12,62 & 2125 & 12,121 & 12,13 & 12,60 & 2155 & 12,124 & 12,13 & 12,61 \\
\hline 2096 & 12,12 & 12,13 & 12,60 & 2126 & 12,121 & 12,13 & 12,60 & 2156 & 12,124 & 12,13 & 12,61 \\
\hline 2097 & 12,12 & 12,13 & 12,60 & 2127 & 12,121 & 12,13 & 12,61 & 2157 & 12,124 & 12,13 & 12,61 \\
\hline 2098 & 12,12 & 12,13 & 12,60 & 2128 & 12,121 & 12,13 & 12,61 & 2158 & 12,124 & 12,13 & 12,61 \\
\hline 2099 & 12,126 & 12,13 & 12,62 & 2129 & 12,121 & 12,13 & 12,61 & 2159 & 12,124 & 12,13 & 12,61 \\
\hline 2100 & 12,126 & 12,13 & 12,62 & 2130 & 12,121 & 12,13 & 12,61 & 2160 & 12,124 & 12,13 & 12,61 \\
\hline 2101 & 12,126 & 12,13 & 12,62 & 2131 & 12,121 & 12,13 & 12,61 & 2161 & 12,124 & 12,13 & 12,61 \\
\hline 2102 & 12,126 & 12,13 & 12,62 & 2132 & 12,121 & 12,13 & 12,60 & 2162 & 12,124 & 12,13 & 12,61 \\
\hline 2103 & 12,126 & 12,13 & 12,62 & 2133 & 12,125 & 12,13 & 12,60 & 2163 & 12,124 & 12,13 & 12,61 \\
\hline 2104 & 12,126 & 12,13 & 12,62 & 2134 & 12,125 & 12,13 & 12,60 & 2164 & 12,123 & 12,13 & 12,61 \\
\hline 2105 & 12,126 & 12,13 & 12,62 & 2135 & 12,125 & 12,13 & 12,60 & 2165 & 12,123 & 12,13 & 12,61 \\
\hline 2106 & 12,126 & 12,13 & 12,60 & 2136 & 12,125 & 12,13 & 12,61 & 2166 & 12,123 & 12,13 & 12,61 \\
\hline 2107 & 12,126 & 12,13 & 12,60 & 2137 & 12,125 & 12,13 & 12,61 & 2167 & 12,123 & 12,13 & 12,61 \\
\hline 2108 & 12,126 & 12,13 & 12,60 & 2138 & 12,125 & 12,13 & 12,61 & 2168 & 12,123 & 12,13 & 12,61 \\
\hline
\end{tabular}


Tabela 30 - Dados obtidos com o rotor da bomba hidráulica girando na frequência de $50 \mathrm{~Hz}$

\begin{tabular}{|c|c|c|c|c|c|c|c|c|c|c|c|}
\hline \multicolumn{12}{|c|}{$\begin{array}{l}\text { Dados obtidos na frequência de } 50 \mathrm{~Hz} \text { : } \\
\text { Tabela com todos valores medidos (Inclui possiveis outliers) }\end{array}$} \\
\hline Medições & $\begin{array}{l}\text { Qpadrão } \\
\mathrm{m}^{3} / \mathrm{h}\end{array}$ & $\begin{array}{l}\text { QIFM } \\
\mathrm{m}^{3} / \mathrm{h} \\
\end{array}$ & $\begin{array}{l}\text { Qvectus } \\
\mathrm{m}^{3} / \mathrm{h}\end{array}$ & Medições & $\begin{array}{l}\text { Qpadrão } \\
\mathrm{m}^{3} / \mathrm{h}\end{array}$ & $\begin{array}{l}Q_{\text {IFM }} \\
\mathrm{m}^{3} / \mathrm{h} \\
\end{array}$ & $\begin{array}{l}\text { QVEctus } \\
\mathrm{m}^{3} / \mathrm{h}\end{array}$ & Medições & $\begin{array}{l}\text { Qpadrão } \\
\mathrm{m}^{3} / \mathrm{h}\end{array}$ & $\begin{array}{l}\text { QIFM } \\
\mathrm{m}^{3} / \mathrm{h} \\
\end{array}$ & $\begin{array}{l}\text { Qvectus } \\
\mathrm{m}^{3} / \mathrm{h}\end{array}$ \\
\hline 1 & 12,244 & 12,30 & 12,22 & 68 & 11,944 & 12,16 & 12,48 & 135 & 12,172 & 12,13 & 12,78 \\
\hline 2 & 12,241 & 12,30 & 12,25 & 69 & 11,944 & 12,17 & 12,50 & 136 & 12,172 & 12,14 & 12,77 \\
\hline 3 & 12,241 & 12,28 & 12,28 & 70 & 11,945 & 12,17 & 12,51 & 137 & 12,172 & 12,15 & 12,77 \\
\hline 4 & 12,237 & 12,27 & 12,29 & 71 & 11,945 & 12,17 & 12,52 & 138 & 11,972 & 12,13 & 12,78 \\
\hline 5 & 12,234 & 12,27 & 12,28 & 72 & 11,945 & 12,17 & 12,52 & 139 & 12,171 & 12,13 & 12,79 \\
\hline 6 & 12,233 & 12,27 & 12,27 & 73 & 12,198 & 12,18 & 12,51 & 140 & 12,171 & 12,15 & 12,79 \\
\hline 7 & 12,232 & 12,25 & 12,25 & 74 & 11,946 & 12,16 & 12,53 & 141 & 12,171 & 12,14 & 12,80 \\
\hline 8 & 12,231 & 12,27 & 12,24 & 75 & 11,947 & 12,18 & 12,52 & 142 & 11,973 & 12,14 & 12,81 \\
\hline 9 & 12,228 & 12,25 & 12,25 & 76 & 12,195 & 12,16 & 12,52 & 143 & 11,973 & 12,14 & 12,82 \\
\hline 10 & 12,228 & 12,23 & 12,26 & 77 & 11,949 & 12,15 & 12,52 & 144 & 11,974 & 12,12 & 12,85 \\
\hline 11 & 12,226 & 12,22 & 12,29 & 78 & 11,951 & 12,16 & 12,54 & 145 & 12,169 & 12,13 & 12,83 \\
\hline 12 & 11,920 & 12,21 & 12,30 & 79 & 11,952 & 12,17 & 12,57 & 146 & 11,975 & 12,15 & 12,83 \\
\hline 13 & 11,920 & 12,22 & 12,29 & 80 & 11,952 & 12,18 & 12,57 & 147 & 12,168 & 12,16 & 12,84 \\
\hline 14 & 12,222 & 12,22 & 12,30 & 81 & 11,953 & 12,17 & 12,60 & 148 & 12,168 & 12,16 & 12,86 \\
\hline 15 & 12,222 & 12,22 & 12,32 & 82 & 11,953 & 12,16 & 12,61 & 149 & 11,976 & 12,15 & 12,85 \\
\hline 16 & 11,922 & 12,20 & 12,31 & 83 & 12,190 & 12,16 & 12,61 & 150 & 12,167 & 12,15 & 12,84 \\
\hline 17 & 11,922 & 12,20 & 12,28 & 84 & 11,954 & 12,15 & 12,57 & 151 & 12,167 & 12,17 & 12,85 \\
\hline 18 & 12,221 & 12,21 & 12,27 & 85 & 11,955 & 12,16 & 12,53 & 152 & 11,977 & 12,17 & 12,86 \\
\hline 19 & 11,923 & 12,22 & 12,28 & 86 & 12,188 & 12,17 & 12,54 & 153 & 12,166 & 12,16 & 12,87 \\
\hline 20 & 11,923 & 12,23 & 12,29 & 87 & 11,956 & 12,16 & 12,52 & 154 & 12,166 & 12,13 & 12,88 \\
\hline 21 & 12,220 & 12,20 & 12,28 & 88 & 12,187 & 12,17 & 12,52 & 155 & 12,166 & 12,13 & 12,86 \\
\hline 22 & 12,220 & 12,22 & 12,28 & 89 & 11,957 & 12,17 & 12,55 & 156 & 11,979 & 12,15 & 12,84 \\
\hline 23 & 11,924 & 12,21 & 12,30 & 90 & 11,957 & 12,19 & 12,57 & 157 & 11,979 & 12,16 & 12,84 \\
\hline 24 & 12,218 & 12,21 & 12,29 & 91 & 12,186 & 12,19 & 12,61 & 158 & 11,979 & 12,13 & 12,84 \\
\hline 25 & 11,928 & 12,22 & 12,28 & 92 & 12,186 & 12,18 & 12,64 & 159 & 12,164 & 12,13 & 12,83 \\
\hline 26 & 12,215 & 12,22 & 12,29 & 93 & 11,959 & 12,17 & 12,66 & 160 & 11,980 & 12,15 & 12,83 \\
\hline 27 & 11,929 & 12,21 & 12,28 & 94 & 11,959 & 12,18 & 12,68 & 161 & 12,163 & 12,15 & 12,83 \\
\hline 28 & 12,214 & 12,22 & 12,30 & 95 & 12,184 & 12,17 & 12,68 & 162 & 11,981 & 12,16 & 12,83 \\
\hline 29 & 12,214 & 12,23 & 12,31 & 96 & 11,960 & 12,17 & 12,69 & 163 & 12,162 & 12,15 & 12,82 \\
\hline 30 & 12,214 & 12,21 & 12,33 & 97 & 12,183 & 12,15 & 12,70 & 164 & 12,162 & 12,14 & 12,82 \\
\hline 31 & 12,214 & 12,21 & 12,35 & 98 & 12,183 & 12,16 & 12,69 & 165 & 11,982 & 12,12 & 12,82 \\
\hline 32 & 12,214 & 12,20 & 12,36 & 99 & 11,961 & 12,17 & 12,68 & 166 & 11,982 & 12,12 & 12,80 \\
\hline 33 & 12,213 & 12,20 & 12,38 & 100 & 12,182 & 12,17 & 12,68 & 167 & 11,983 & 12,12 & 12,78 \\
\hline 34 & 12,213 & 12,21 & 12,39 & 101 & 12,182 & 12,18 & 12,70 & 168 & 12,160 & 12,15 & 12,79 \\
\hline 35 & 12,213 & 12,20 & 12,39 & 102 & 12,181 & 12,15 & 12,68 & 169 & 12,160 & 12,15 & 12,78 \\
\hline 36 & 12,212 & 12,21 & 12,38 & 103 & 12,181 & 12,15 & 12,66 & 170 & 12,160 & 12,14 & 12,75 \\
\hline 37 & 12,211 & 12,21 & 12,37 & 104 & 11,963 & 12,15 & 12,65 & 171 & 12,160 & 12,12 & 12,72 \\
\hline 38 & 12,211 & 12,20 & 12,36 & 105 & 12,180 & 12,14 & 12,66 & 172 & 12,160 & 12,13 & 12,69 \\
\hline 39 & 12,210 & 12,18 & 12,36 & 106 & 12,180 & 12,14 & 12,71 & 173 & 11,984 & 12,13 & 12,68 \\
\hline 40 & 12,210 & 12,19 & 12,34 & 107 & 12,179 & 12,15 & 12,71 & 174 & 11,984 & 12,13 & 12,68 \\
\hline 41 & 12,210 & 12,19 & 12,35 & 108 & 12,179 & 12,16 & 12,71 & 175 & 11,984 & 12,12 & 12,69 \\
\hline 42 & 11,934 & 12,18 & 12,37 & 109 & 12,179 & 12,16 & 12,72 & 176 & 12,159 & 12,12 & 12,69 \\
\hline 43 & 11,934 & 12,20 & 12,40 & 110 & 11,965 & 12,17 & 12,73 & 177 & 12,159 & 12,14 & 12,68 \\
\hline 44 & 12,209 & 12,20 & 12,43 & 111 & 11,965 & 12,17 & 12,74 & 178 & 12,159 & 12,15 & 12,68 \\
\hline 45 & 12,209 & 12,19 & 12,43 & 112 & 11,965 & 12,16 & 12,73 & 179 & 11,985 & 12,14 & 12,69 \\
\hline 46 & 11,935 & 12,20 & 12,44 & 113 & 12,178 & 12,13 & 12,74 & 180 & 11,985 & 12,14 & 12,71 \\
\hline 47 & 11,935 & 12,20 & 12,44 & 114 & 12,178 & 12,17 & 12,76 & 181 & 12,158 & 12,13 & 12,73 \\
\hline 48 & 12,208 & 12,21 & 12,44 & 115 & 12,178 & 12,17 & 12,78 & 182 & 12,158 & 12,11 & 12,74 \\
\hline 49 & 12,208 & 12,21 & 12,44 & 116 & 12,178 & 12,17 & 12,80 & 183 & 11,986 & 12,11 & 12,71 \\
\hline 50 & 11,936 & 12,22 & 12,45 & 117 & 11,966 & 12,18 & 12,80 & 184 & 11,986 & 12,11 & 12,72 \\
\hline 51 & 11,937 & 12,23 & 12,45 & 118 & 11,966 & 12,17 & 12,80 & 185 & 12,157 & 12,12 & 12,71 \\
\hline 52 & 12,206 & 12,18 & 12,43 & 119 & 12,177 & 12,15 & 12,81 & 186 & 11,987 & 12,14 & 12,72 \\
\hline 53 & 12,206 & 12,17 & 12,43 & 120 & 12,176 & 12,12 & 12,80 & 187 & 11,987 & 12,14 & 12,71 \\
\hline 54 & 12,206 & 12,20 & 12,43 & 121 & 11,968 & 12,14 & 12,82 & 188 & 12,156 & 12,14 & 12,70 \\
\hline 55 & 12,205 & 12,21 & 12,44 & 122 & 12,175 & 12,16 & 12,82 & 189 & 12,156 & 12,12 & 12,70 \\
\hline 56 & 11,939 & 12,19 & 12,44 & 123 & 11,969 & 12,15 & 12,81 & 190 & 12,156 & 12,12 & 12,69 \\
\hline 57 & 12,204 & 12,19 & 12,43 & 124 & 11,969 & 12,16 & 12,79 & 191 & 12,156 & 12,10 & 12,67 \\
\hline 58 & 12,204 & 12,19 & 12,45 & 125 & 12,174 & 12,17 & 12,79 & 192 & 11,988 & 12,10 & 12,68 \\
\hline 59 & 11,940 & 12,22 & 12,47 & 126 & 12,174 & 12,16 & 12,78 & 193 & 12,155 & 12,12 & 12,68 \\
\hline 60 & 12,203 & 12,23 & 12,48 & 127 & 11,970 & 12,15 & 12,76 & 194 & 12,155 & 12,13 & 12,66 \\
\hline 61 & 12,203 & 12,21 & 12,48 & 128 & 12,173 & 12,15 & 12,77 & 195 & 12,155 & 12,14 & 12,67 \\
\hline 62 & 11,941 & 12,21 & 12,48 & 129 & 12,173 & 12,14 & 12,79 & 196 & 12,155 & 12,14 & 12,66 \\
\hline 63 & 12,202 & 12,20 & 12,48 & 130 & 12,173 & 12,15 & 12,80 & 197 & 12,155 & 12,14 & 12,65 \\
\hline 64 & 12,202 & 12,20 & 12,47 & 131 & 11,971 & 12,12 & 12,78 & 198 & 12,155 & 12,14 & 12,65 \\
\hline 65 & 12,201 & 12,19 & 12,46 & 132 & 11,971 & 12,13 & 12,77 & 199 & 11,989 & 12,14 & 12,66 \\
\hline 66 & 11,943 & 12,19 & 12,46 & 133 & 12,172 & 12,13 & 12,75 & & & & \\
\hline 67 & 12,200 & 12,20 & 12,47 & 134 & 12,172 & 12,13 & 12,77 & & & & \\
\hline
\end{tabular}




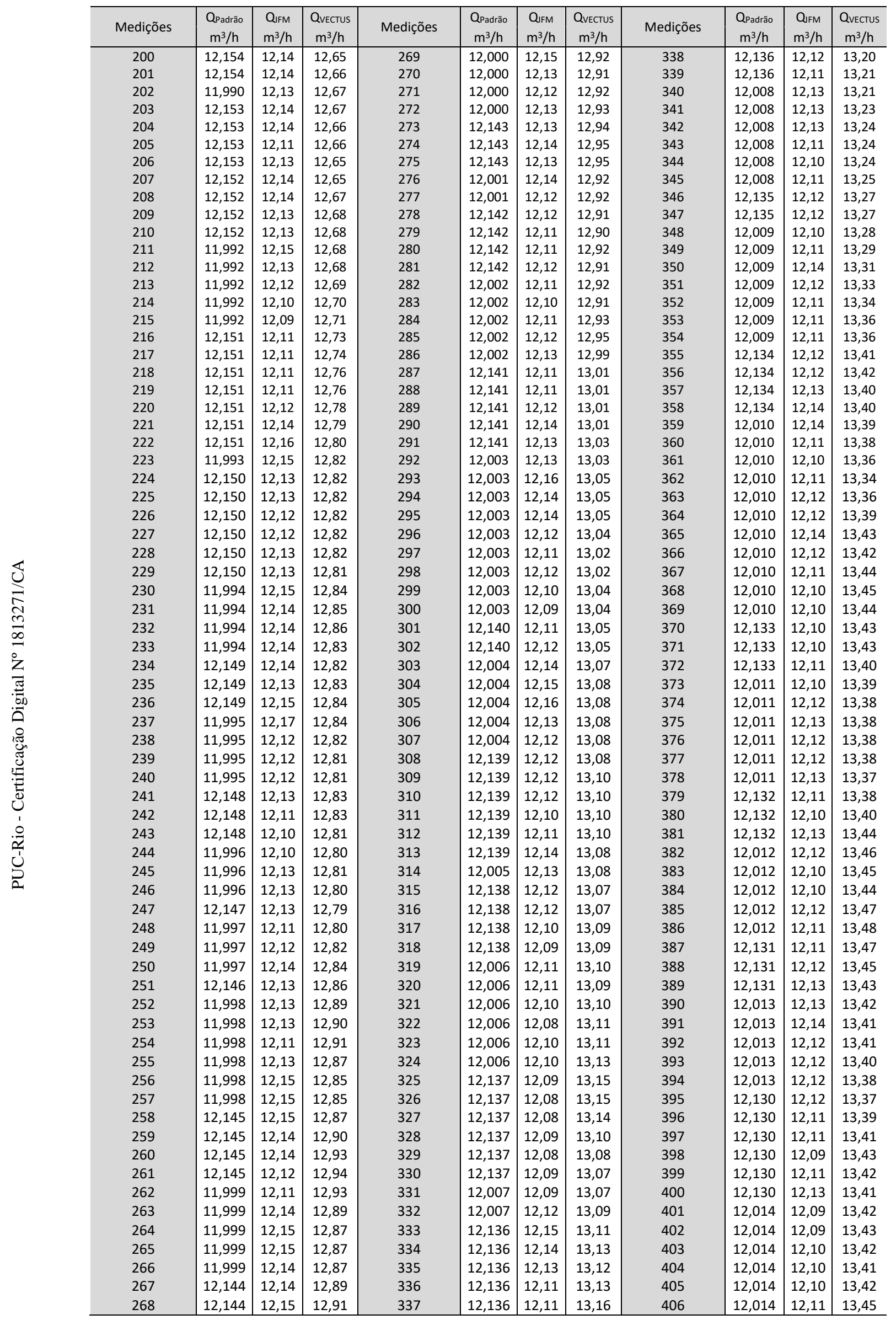




\begin{tabular}{|c|c|c|c|c|c|c|c|c|c|c|c|}
\hline Medições & $\begin{array}{l}\text { Qpadrão } \\
\mathrm{m}^{3} / \mathrm{h}\end{array}$ & $\begin{array}{l}\text { QIFM } \\
\mathrm{m}^{3} / \mathrm{h}\end{array}$ & $\begin{array}{l}\text { Qvectus } \\
\mathrm{m}^{3} / \mathrm{h}\end{array}$ & Medições & $\begin{array}{l}\text { Qpadrão } \\
\mathrm{m}^{3} / \mathrm{h}\end{array}$ & $\begin{array}{l}\text { QIFM } \\
\mathrm{m}^{3} / \mathrm{h}\end{array}$ & $\begin{array}{c}\text { Qvectus } \\
\mathrm{m}^{3} / \mathrm{h}\end{array}$ & Medições & $\begin{array}{l}\text { Qpadrão } \\
\mathrm{m}^{3} / \mathrm{h}\end{array}$ & $\begin{array}{l}\text { QIFM } \\
\mathrm{m}^{3} / \mathrm{h}\end{array}$ & $\begin{array}{l}\text { Qvectus } \\
\mathrm{m}^{3} / \mathrm{h}\end{array}$ \\
\hline 407 & 12,014 & 12,11 & 13,47 & 476 & 12,020 & 12,10 & 13,13 & 545 & 12,024 & 12,11 & 12,80 \\
\hline 408 & 12,014 & 12,11 & 13,48 & 477 & 12,020 & 12,10 & 13,14 & 546 & 12,024 & 12,10 & 12,80 \\
\hline 409 & 12,014 & 12,08 & 13,46 & 478 & 12,020 & 12,12 & 13,14 & 547 & 12,024 & 12,10 & 12,82 \\
\hline 410 & 12,014 & 12,08 & 13,46 & 479 & 12,020 & 12,13 & 13,15 & 548 & 12,024 & 12,08 & 12,84 \\
\hline 411 & 12,014 & 12,10 & 13,47 & 480 & 12,020 & 12,11 & 13,16 & 549 & 12,024 & 12,08 & 12,85 \\
\hline 412 & 12,014 & 12,11 & 13,51 & 481 & 12,020 & 12,09 & 13,14 & 550 & 12,024 & 12,06 & 12,85 \\
\hline 413 & 12,014 & 12,10 & 13,52 & 482 & 12,020 & 12,09 & 13,13 & 551 & 12,024 & 12,08 & 12,86 \\
\hline 414 & 12,014 & 12,11 & 13,54 & 483 & 12,020 & 12,10 & 13,12 & 552 & 12,024 & 12,10 & 12,87 \\
\hline 415 & 12,014 & 12,10 & 13,55 & 484 & 12,020 & 12,10 & 13,12 & 553 & 12,024 & 12,10 & 12,87 \\
\hline 416 & 12,129 & 12,10 & 13,55 & 485 & 12,020 & 12,11 & 13,12 & 554 & 12,024 & 12,08 & 12,89 \\
\hline 417 & 12,129 & 12,11 & 13,53 & 486 & 12,020 & 12,11 & 13,10 & 555 & 12,119 & 12,09 & 12,89 \\
\hline 418 & 12,129 & 12,12 & 13,51 & 487 & 12,020 & 12,14 & 13,06 & 556 & 12,119 & 12,10 & 12,90 \\
\hline 419 & 12,015 & 12,09 & 13,48 & 488 & 12,020 & 12,12 & 13,04 & 557 & 12,119 & 12,10 & 12,90 \\
\hline 420 & 12,015 & 12,09 & 13,46 & 489 & 12,020 & 12,11 & 13,03 & 558 & 12,119 & 12,07 & 12,88 \\
\hline 421 & 12,015 & 12,10 & 13,46 & 490 & 12,020 & 12,08 & 13,05 & 559 & 12,119 & 12,05 & 12,88 \\
\hline 422 & 12,015 & 12,10 & 13,48 & 491 & 12,020 & 12,08 & 13,04 & 560 & 12,119 & 12,04 & 12,85 \\
\hline 423 & 12,015 & 12,09 & 13,50 & 492 & 12,123 & 12,08 & 13,03 & 561 & 12,119 & 12,06 & 12,84 \\
\hline 424 & 12,015 & 12,11 & 13,49 & 493 & 12,123 & 12,09 & 13,02 & 562 & 12,025 & 12,08 & 12,83 \\
\hline 425 & 12,015 & 12,13 & 13,50 & 494 & 12,123 & 12,10 & 13,01 & 563 & 12,025 & 12,09 & 12,84 \\
\hline 426 & 12,015 & 12,12 & 13,50 & 495 & 12,123 & 12,08 & 13,00 & 564 & 12,025 & 12,09 & 12,87 \\
\hline 427 & 12,128 & 12,11 & 13,50 & 496 & 12,123 & 12,02 & 12,98 & 565 & 12,025 & 12,08 & 12,90 \\
\hline 428 & 12,128 & 12,12 & 13,48 & 497 & 12,021 & 11,97 & 12,95 & 566 & 12,025 & 12,09 & 12,87 \\
\hline 429 & 12,128 & 12,12 & 13,45 & 498 & 12,021 & 11,95 & 12,91 & 567 & 12,025 & 12,12 & 12,87 \\
\hline 430 & 12,016 & 12,11 & 13,44 & 499 & 12,021 & 11,98 & 12,89 & 568 & 12,025 & 12,12 & 12,90 \\
\hline 431 & 12,016 & 12,12 & 13,45 & 500 & 12,021 & 12,02 & 12,86 & 569 & 12,025 & 12,11 & 12,90 \\
\hline 432 & 12,016 & 12,11 & 13,48 & 501 & 12,021 & 12,06 & 12,85 & 570 & 12,025 & 12,11 & 12,88 \\
\hline 433 & 12,016 & 12,11 & 13,47 & 502 & 12,021 & 12,07 & 12,86 & 571 & 12,025 & 12,09 & 12,86 \\
\hline 434 & 12,016 & 12,12 & 13,49 & 503 & 12,021 & 12,05 & 12,85 & 572 & 12,025 & 12,08 & 12,84 \\
\hline 435 & 12,016 & 12,11 & 13,50 & 504 & 12,021 & 12,06 & 12,84 & 573 & 12,118 & 12,09 & 12,81 \\
\hline 436 & 12,016 & 12,11 & 13,49 & 505 & 12,021 & 12,07 & 12,83 & 574 & 12,118 & 12,10 & 12,80 \\
\hline 437 & 12,016 & 12,11 & 13,47 & 506 & 12,021 & 12,09 & 12,84 & 575 & 12,118 & 12,06 & 12,76 \\
\hline 438 & 12,127 & 12,12 & 13,44 & 507 & 12,021 & 12,09 & 12,85 & 576 & 12,118 & 12,06 & 12,73 \\
\hline 439 & 12,127 & 12,12 & 13,45 & 508 & 12,122 & 12,07 & 12,86 & 577 & 12,118 & 12,07 & 12,73 \\
\hline 440 & 12,127 & 12,11 & 13,44 & 509 & 12,122 & 12,08 & 12,88 & 578 & 12,026 & 12,10 & 12,72 \\
\hline 441 & 12,127 & 12,12 & 13,44 & 510 & 12,122 & 12,07 & 12,90 & 579 & 12,026 & 12,11 & 12,70 \\
\hline 442 & 12,017 & 12,10 & 13,44 & 511 & 12,122 & 12,04 & 12,96 & 580 & 12,026 & 12,11 & 12,71 \\
\hline 443 & 12,017 & 12,11 & 13,41 & 512 & 12,122 & 12,00 & 12,96 & 581 & 12,026 & 12,10 & 12,72 \\
\hline 444 & 12,017 & 12,11 & 13,41 & 513 & 12,122 & 11,97 & 12,93 & 582 & 12,026 & 12,07 & 12,74 \\
\hline 445 & 12,126 & 12,10 & 13,42 & 514 & 12,022 & 11,97 & 12,87 & 583 & 12,026 & 12,05 & 12,73 \\
\hline 446 & 12,126 & 12,11 & 13,39 & 515 & 12,022 & 11,96 & 12,85 & 584 & 12,026 & 12,06 & 12,71 \\
\hline 447 & 12,126 & 12,10 & 13,35 & 516 & 12,022 & 11,97 & 12,84 & 585 & 12,026 & 12,08 & 12,72 \\
\hline 448 & 12,126 & 12,11 & 13,34 & 517 & 12,022 & 11,98 & 12,81 & 586 & 12,026 & 12,08 & 12,72 \\
\hline 449 & 12,126 & 12,11 & 13,34 & 518 & 12,022 & 11,99 & 12,80 & 587 & 12,117 & 12,07 & 12,70 \\
\hline 450 & 12,126 & 12,11 & 13,31 & 519 & 12,022 & 11,98 & 12,81 & 588 & 12,117 & 12,07 & 12,70 \\
\hline 451 & 12,126 & 12,08 & 13,31 & 520 & 12,022 & 11,96 & 12,82 & 589 & 12,117 & 12,06 & 12,71 \\
\hline 452 & 12,018 & 12,10 & 13,30 & 521 & 12,121 & 11,96 & 12,81 & 590 & 12,117 & 12,05 & 12,71 \\
\hline 453 & 12,018 & 12,09 & 13,31 & 522 & 12,121 & 11,99 & 12,83 & 591 & 12,117 & 12,07 & 12,75 \\
\hline 454 & 12,018 & 12,07 & 13,32 & 523 & 12,121 & 12,03 & 12,85 & 592 & 12,117 & 12,08 & 12,79 \\
\hline 455 & 12,018 & 12,10 & 13,33 & 524 & 12,121 & 12,05 & 12,86 & 593 & 12,117 & 12,08 & 12,80 \\
\hline 456 & 12,018 & 12,10 & 13,35 & 525 & 12,121 & 12,05 & 12,86 & 594 & 12,027 & 12,08 & 12,80 \\
\hline 457 & 12,018 & 12,08 & 13,37 & 526 & 12,121 & 12,07 & 12,88 & 595 & 12,027 & 12,08 & 12,82 \\
\hline 458 & 12,125 & 12,08 & 13,39 & 527 & 12,121 & 12,04 & 12,89 & 596 & 12,027 & 12,07 & 12,82 \\
\hline 459 & 12,125 & 12,10 & 13,39 & 528 & 12,121 & 12,05 & 12,92 & 597 & 12,027 & 12,08 & 12,84 \\
\hline 460 & 12,125 & 12,09 & 13,35 & 529 & 12,023 & 12,05 & 12,94 & 598 & 12,027 & 12,09 & 12,80 \\
\hline 461 & 12,125 & 12,10 & 13,36 & 530 & 12,023 & 12,06 & 12,94 & 599 & 12,027 & 12,08 & 12,76 \\
\hline 462 & 12,125 & 12,08 & 13,36 & 531 & 12,023 & 12,06 & 12,93 & 600 & 12,027 & 12,09 & 12,72 \\
\hline 463 & 12,019 & 12,10 & 13,36 & 532 & 12,023 & 12,07 & 12,92 & 601 & 12,027 & 12,10 & 12,72 \\
\hline 464 & 12,019 & 12,12 & 13,36 & 533 & 12,023 & 12,10 & 12,91 & 602 & 12,027 & 12,08 & 12,71 \\
\hline 465 & 12,019 & 12,12 & 13,35 & 534 & 12,023 & 12,09 & 12,92 & 603 & 12,116 & 12,06 & 12,73 \\
\hline 466 & 12,019 & 12,12 & 13,34 & 535 & 12,023 & 12,10 & 12,91 & 604 & 12,116 & 12,06 & 12,73 \\
\hline 467 & 12,019 & 12,12 & 13,32 & 536 & 12,023 & 12,11 & 12,92 & 605 & 12,116 & 12,09 & 12,73 \\
\hline 468 & 12,019 & 12,12 & 13,31 & 537 & 12,023 & 12,10 & 12,93 & 606 & 12,116 & 12,10 & 12,70 \\
\hline 469 & 12,124 & 12,11 & 13,30 & 538 & 12,023 & 12,09 & 12,94 & 607 & 12,116 & 12,08 & 12,70 \\
\hline 470 & 12,124 & 12,09 & 13,29 & 539 & 12,120 & 12,10 & 12,93 & 608 & 12,116 & 12,11 & 12,68 \\
\hline 471 & 12,124 & 12,08 & 13,25 & 540 & 12,120 & 12,09 & 12,92 & 609 & 12,116 & 12,10 & 12,70 \\
\hline 472 & 12,124 & 12,08 & 13,22 & 541 & 12,120 & 12,09 & 12,89 & 610 & 12,116 & 12,08 & 12,70 \\
\hline 473 & 12,124 & 12,09 & 13,18 & 542 & 12,120 & 12,09 & 12,87 & 611 & 12,028 & 12,07 & 12,68 \\
\hline 474 & 12,124 & 12,09 & 13,16 & 543 & 12,024 & 12,09 & 12,81 & 612 & 12,028 & 12,07 & 12,66 \\
\hline 475 & 12,124 & 12,11 & 13,15 & 544 & 12,024 & 12,11 & 12,80 & 613 & 12,028 & 12,06 & 12,63 \\
\hline
\end{tabular}




\begin{tabular}{|c|c|c|c|c|c|c|c|c|c|c|c|}
\hline Medições & $\begin{array}{l}\text { Qpadrão } \\
\mathrm{m}^{3} / \mathrm{h}\end{array}$ & $\begin{array}{l}\text { Q1FM } \\
\mathrm{m}^{3} / \mathrm{h}\end{array}$ & $\begin{array}{c}\text { Qvectus } \\
\mathrm{m}^{3} / \mathrm{h}\end{array}$ & Medições & $\begin{array}{l}\text { Qpadrão } \\
\mathrm{m}^{3} / \mathrm{h}\end{array}$ & $\begin{array}{c}Q_{\text {IFM }} \\
\mathrm{m}^{3} / \mathrm{h}\end{array}$ & $\begin{array}{l}\text { Qvectus } \\
\mathrm{m}^{3} / \mathrm{h}\end{array}$ & Medições & $\begin{array}{l}\text { Qpadrão } \\
\mathrm{m}^{3} / \mathrm{h}\end{array}$ & $\begin{array}{l}Q_{\text {IFM }} \\
\mathrm{m}^{3} / \mathrm{h}\end{array}$ & $\begin{array}{l}\text { Qvectus } \\
\mathrm{m}^{3} / \mathrm{h}\end{array}$ \\
\hline 614 & 12,028 & 12,09 & 12,62 & 683 & 12,031 & 12,11 & 12,54 & 752 & 12,034 & 12,09 & 12,63 \\
\hline 615 & 12,028 & 12,09 & 12,62 & 684 & 12,031 & 12,07 & 12,56 & 753 & 12,034 & 12,08 & 12,62 \\
\hline 616 & 12,028 & 12,07 & 12,61 & 685 & 12,031 & 12,05 & 12,58 & 754 & 12,034 & 12,07 & 12,62 \\
\hline 617 & 12,028 & 12,06 & 12,61 & 686 & 12,031 & 12,06 & 12,62 & 755 & 12,109 & 12,06 & 12,64 \\
\hline 618 & 12,028 & 12,07 & 12,60 & 687 & 12,112 & 12,07 & 12,69 & 756 & 12,109 & 12,07 & 12,66 \\
\hline 619 & 12,028 & 12,09 & 12,59 & 688 & 12,112 & 12,08 & 12,68 & 757 & 12,109 & 12,07 & 12,66 \\
\hline 620 & 12,028 & 12,08 & 12,58 & 689 & 12,112 & 12,06 & 12,67 & 758 & 12,109 & 12,07 & 12,64 \\
\hline 621 & 12,115 & 12,07 & 12,59 & 690 & 12,112 & 12,07 & 12,66 & 759 & 12,109 & 12,09 & 12,64 \\
\hline 622 & 12,115 & 12,08 & 12,59 & 691 & 12,112 & 12,06 & 12,63 & 760 & 12,109 & 12,08 & 12,64 \\
\hline 623 & 12,115 & 12,11 & 12,60 & 692 & 12,112 & 12,08 & 12,63 & 761 & 12,109 & 12,08 & 12,66 \\
\hline 624 & 12,115 & 12,12 & 12,61 & 693 & 12,112 & 12,08 & 12,64 & 762 & 12,109 & 12,07 & 12,67 \\
\hline 625 & 12,115 & 12,13 & 12,59 & 694 & 12,112 & 12,08 & 12,65 & 763 & 12,035 & 12,07 & 12,64 \\
\hline 626 & 12,115 & 12,11 & 12,58 & 695 & 12,112 & 12,09 & 12,64 & 764 & 12,035 & 12,06 & 12,65 \\
\hline 627 & 12,115 & 12,07 & 12,59 & 696 & 12,032 & 12,10 & 12,65 & 765 & 12,035 & 12,06 & 12,65 \\
\hline 628 & 12,115 & 12,06 & 12,58 & 697 & 12,032 & 12,08 & 12,65 & 766 & 12,035 & 12,06 & 12,65 \\
\hline 629 & 12,029 & 12,07 & 12,55 & 698 & 12,032 & 12,08 & 12,65 & 767 & 12,035 & 12,08 & 12,66 \\
\hline 630 & 12,029 & 12,08 & 12,52 & 699 & 12,032 & 12,07 & 12,64 & 768 & 12,035 & 12,10 & 12,67 \\
\hline 631 & 12,029 & 12,09 & 12,50 & 700 & 12,032 & 12,08 & 12,64 & 769 & 12,035 & 12,10 & 12,71 \\
\hline 632 & 12,029 & 12,10 & 12,50 & 701 & 12,032 & 12,11 & 12,62 & 770 & 12,035 & 12,10 & 12,70 \\
\hline 633 & 12,029 & 12,09 & 12,52 & 702 & 12,032 & 12,11 & 12,62 & 771 & 12,035 & 12,08 & 12,70 \\
\hline 634 & 12,029 & 12,09 & 12,52 & 703 & 12,032 & 12,07 & 12,62 & 772 & 12,108 & 12,08 & 12,69 \\
\hline 635 & 12,029 & 12,09 & 12,52 & 704 & 12,032 & 12,06 & 12,60 & 773 & 12,108 & 12,08 & 12,66 \\
\hline 636 & 12,029 & 12,11 & 12,53 & 705 & 12,111 & 12,07 & 12,60 & 774 & 12,108 & 12,07 & 12,66 \\
\hline 637 & 12,029 & 12,10 & 12,55 & 706 & 12,111 & 12,06 & 12,62 & 775 & 12,108 & 12,05 & 12,70 \\
\hline 638 & 12,029 & 12,08 & 12,55 & 707 & 12,111 & 12,08 & 12,66 & 776 & 12,108 & 12,05 & 12,70 \\
\hline 639 & 12,029 & 12,06 & 12,55 & 708 & 12,111 & 12,07 & 12,68 & 777 & 12,108 & 12,01 & 12,70 \\
\hline 640 & 12,029 & 12,05 & 12,52 & 709 & 12,111 & 12,08 & 12,70 & 778 & 12,108 & 12,03 & 12,71 \\
\hline 641 & 12,029 & 12,06 & 12,49 & 710 & 12,111 & 12,08 & 12,69 & 779 & 12,108 & 12,05 & 12,73 \\
\hline 642 & 12,029 & 12,07 & 12,50 & 711 & 12,111 & 12,07 & 12,69 & 780 & 12,108 & 12,08 & 12,75 \\
\hline 643 & 12,029 & 12,08 & 12,52 & 712 & 12,111 & 12,05 & 12,69 & 781 & 12,108 & 12,05 & 12,72 \\
\hline 644 & 12,029 & 12,08 & 12,50 & 713 & 12,111 & 12,06 & 12,68 & 782 & 12,108 & 12,06 & 12,70 \\
\hline 645 & 12,114 & 12,11 & 12,49 & 714 & 12,111 & 12,06 & 12,69 & 783 & 12,108 & 12,04 & 12,69 \\
\hline 646 & 12,114 & 12,10 & 12,47 & 715 & 12,111 & 12,05 & 12,68 & 784 & 12,036 & 12,09 & 12,67 \\
\hline 647 & 12,114 & 12,09 & 12,48 & 716 & 12,111 & 12,06 & 12,68 & 785 & 12,036 & 12,07 & 12,66 \\
\hline 648 & 12,114 & 12,09 & 12,47 & 717 & 12,033 & 12,07 & 12,67 & 786 & 12,036 & 12,05 & 12,65 \\
\hline 649 & 12,114 & 12,09 & 12,47 & 718 & 12,033 & 12,07 & 12,69 & 787 & 12,036 & 12,01 & 12,64 \\
\hline 650 & 12,114 & 12,07 & 12,49 & 719 & 12,033 & 12,08 & 12,71 & 788 & 12,036 & 12,04 & 12,63 \\
\hline 651 & 12,114 & 12,07 & 12,46 & 720 & 12,033 & 12,07 & 12,69 & 789 & 12,036 & 12,04 & 12,62 \\
\hline 652 & 12,114 & 12,10 & 12,43 & 721 & 12,033 & 12,07 & 12,66 & 790 & 12,036 & 12,06 & 12,62 \\
\hline 653 & 12,114 & 12,10 & 12,44 & 722 & 12,033 & 12,06 & 12,66 & 791 & 12,036 & 12,06 & 12,61 \\
\hline 654 & 12,114 & 12,09 & 12,44 & 723 & 12,033 & 12,04 & 12,65 & 792 & 12,036 & 12,06 & 12,63 \\
\hline 655 & 12,114 & 12,08 & 12,44 & 724 & 12,033 & 12,06 & 12,64 & 793 & 12,036 & 12,05 & 12,65 \\
\hline 656 & 12,030 & 12,09 & 12,47 & 725 & 12,033 & 12,07 & 12,65 & 794 & 12,036 & 12,03 & 12,67 \\
\hline 657 & 12,030 & 12,09 & 12,47 & 726 & 12,033 & 12,06 & 12,65 & 795 & 12,036 & 12,00 & 12,67 \\
\hline 658 & 12,030 & 12,07 & 12,48 & 727 & 12,033 & 12,08 & 12,65 & 796 & 12,036 & 12,00 & 12,66 \\
\hline 659 & 12,030 & 12,08 & 12,49 & 728 & 12,033 & 12,09 & 12,67 & 797 & 12,107 & 12,03 & 12,66 \\
\hline 660 & 12,030 & 12,08 & 12,50 & 729 & 12,033 & 12,07 & 12,67 & 798 & 12,107 & 12,05 & 12,67 \\
\hline 661 & 12,030 & 12,11 & 12,52 & 730 & 12,033 & 12,07 & 12,66 & 799 & 12,107 & 12,08 & 12,64 \\
\hline 662 & 12,030 & 12,09 & 12,51 & 731 & 12,110 & 12,07 & 12,66 & 800 & 12,107 & 12,08 & 12,64 \\
\hline 663 & 12,030 & 12,10 & 12,50 & 732 & 12,110 & 12,07 & 12,67 & 801 & 12,107 & 12,09 & 12,65 \\
\hline 664 & 12,030 & 12,10 & 12,50 & 733 & 12,110 & 12,08 & 12,70 & 802 & 12,107 & 12,09 & 12,65 \\
\hline 665 & 12,030 & 12,08 & 12,49 & 734 & 12,110 & 12,07 & 12,74 & 803 & 12,107 & 12,07 & 12,65 \\
\hline 666 & 12,113 & 12,08 & 12,49 & 735 & 12,110 & 12,08 & 12,76 & 804 & 12,107 & 12,09 & 12,65 \\
\hline 667 & 12,113 & 12,06 & 12,52 & 736 & 12,110 & 12,10 & 12,75 & 805 & 12,107 & 12,06 & 12,66 \\
\hline 668 & 12,113 & 12,05 & 12,54 & 737 & 12,110 & 12,05 & 12,74 & 806 & 12,107 & 12,06 & 12,68 \\
\hline 669 & 12,113 & 12,07 & 12,54 & 738 & 12,110 & 12,05 & 12,74 & 807 & 12,107 & 12,06 & 12,68 \\
\hline 670 & 12,113 & 12,08 & 12,54 & 739 & 12,110 & 12,05 & 12,73 & 808 & 12,037 & 12,05 & 12,68 \\
\hline 671 & 12,113 & 12,09 & 12,54 & 740 & 12,110 & 12,07 & 12,72 & 809 & 12,037 & 12,06 & 12,69 \\
\hline 672 & 12,113 & 12,09 & 12,54 & 741 & 12,034 & 12,08 & 12,73 & 810 & 12,037 & 12,08 & 12,69 \\
\hline 673 & 12,113 & 12,08 & 12,53 & 742 & 12,034 & 12,08 & 12,73 & 811 & 12,037 & 12,07 & 12,69 \\
\hline 674 & 12,113 & 12,07 & 12,54 & 743 & 12,034 & 12,07 & 12,71 & 812 & 12,037 & 12,06 & 12,69 \\
\hline 675 & 12,031 & 12,08 & 12,56 & 744 & 12,034 & 12,06 & 12,68 & 813 & 12,037 & 12,04 & 12,68 \\
\hline 676 & 12,031 & 12,10 & 12,55 & 745 & 12,034 & 12,07 & 12,66 & 814 & 12,037 & 12,06 & 12,69 \\
\hline 677 & 12,031 & 12,10 & 12,51 & 746 & 12,034 & 12,09 & 12,65 & 815 & 12,037 & 12,07 & 12,68 \\
\hline 678 & 12,031 & 12,09 & 12,50 & 747 & 12,034 & 12,09 & 12,65 & 816 & 12,037 & 12,08 & 12,70 \\
\hline 679 & 12,031 & 12,08 & 12,51 & 748 & 12,034 & 12,08 & 12,66 & 817 & 12,037 & 12,08 & 12,71 \\
\hline 680 & 12,031 & 12,09 & 12,51 & 749 & 12,034 & 12,08 & 12,68 & 818 & 12,037 & 12,08 & 12,70 \\
\hline 681 & 12,031 & 12,08 & 12,51 & 750 & 12,034 & 12,08 & 12,69 & 819 & 12,037 & 12,09 & 12,73 \\
\hline 682 & 12,031 & 12,09 & 12,52 & 751 & 12,034 & 12,08 & 12,66 & 820 & 12,037 & 12,08 & 12,72 \\
\hline
\end{tabular}




\begin{tabular}{|c|c|c|c|c|c|c|c|c|c|c|c|}
\hline Medições & $\begin{array}{l}\text { Qpadrão } \\
\mathrm{m}^{3} / \mathrm{h}\end{array}$ & $\begin{array}{l}Q_{1 F M} \\
\mathrm{~m}^{3} / \mathrm{h}\end{array}$ & $\begin{array}{l}\text { Qvectus } \\
\mathrm{m}^{3} / \mathrm{h}\end{array}$ & Medições & $\begin{array}{l}\text { Qpadrão } \\
\mathrm{m}^{3} / \mathrm{h}\end{array}$ & $\begin{array}{l}\text { QIFM } \\
\mathrm{m}^{3} / \mathrm{h}\end{array}$ & $\begin{array}{l}\text { Qvectus } \\
\mathrm{m}^{3} / \mathrm{h}\end{array}$ & Medições & $\begin{array}{l}\text { Qpadrão } \\
\mathrm{m}^{3} / \mathrm{h}\end{array}$ & $\begin{array}{c}Q_{1 F M} \\
\mathrm{~m}^{3} / \mathrm{h}\end{array}$ & $\begin{array}{l}\text { Qvectus } \\
\mathrm{m}^{3} / \mathrm{h}\end{array}$ \\
\hline 821 & 12,037 & 12,06 & 12,71 & 890 & 12,040 & 12,08 & 12,66 & 959 & 12,101 & 12,06 & 12,59 \\
\hline 822 & 12,037 & 12,07 & 12,72 & 891 & 12,040 & 12,08 & 12,67 & 960 & 12,101 & 12,07 & 12,58 \\
\hline 823 & 12,037 & 12,06 & 12,72 & 892 & 12,040 & 12,05 & 12,67 & 961 & 12,101 & 12,07 & 12,57 \\
\hline 824 & 12,037 & 12,07 & 12,71 & 893 & 12,040 & 12,04 & 12,67 & 962 & 12,101 & 12,08 & 12,58 \\
\hline 825 & 12,037 & 12,06 & 12,70 & 894 & 12,040 & 12,05 & 12,65 & 963 & 12,101 & 12,10 & 12,59 \\
\hline 826 & 12,037 & 12,06 & 12,71 & 895 & 12,040 & 12,05 & 12,64 & 964 & 12,101 & 12,09 & 12,61 \\
\hline 827 & 12,037 & 12,07 & 12,73 & 896 & 12,103 & 12,07 & 12,63 & 965 & 12,043 & 12,09 & 12,62 \\
\hline 828 & 12,037 & 12,09 & 12,73 & 897 & 12,103 & 12,08 & 12,63 & 966 & 12,043 & 12,09 & 12,63 \\
\hline 829 & 12,037 & 12,09 & 12,72 & 898 & 12,103 & 12,08 & 12,63 & 967 & 12,043 & 12,08 & 12,63 \\
\hline 830 & 12,037 & 12,10 & 12,72 & 899 & 12,103 & 12,08 & 12,63 & 968 & 12,043 & 12,09 & 12,63 \\
\hline 831 & 12,037 & 12,09 & 12,73 & 900 & 12,103 & 12,08 & 12,65 & 969 & 12,043 & 12,08 & 12,64 \\
\hline 832 & 12,106 & 12,08 & 12,74 & 901 & 12,103 & 12,08 & 12,64 & 970 & 12,043 & 12,07 & 12,66 \\
\hline 833 & 12,106 & 12,10 & 12,75 & 902 & 12,103 & 12,08 & 12,64 & 971 & 12,043 & 12,07 & 12,64 \\
\hline 834 & 12,106 & 12,09 & 12,76 & 903 & 12,103 & 12,08 & 12,64 & 972 & 12,043 & 12,08 & 12,62 \\
\hline 835 & 12,106 & 12,09 & 12,74 & 904 & 12,103 & 12,06 & 12,63 & 973 & 12,043 & 12,06 & 12,61 \\
\hline 836 & 12,106 & 12,09 & 12,73 & 905 & 12,103 & 12,06 & 12,66 & 974 & 12,043 & 12,06 & 12,61 \\
\hline 837 & 12,106 & 12,09 & 12,71 & 906 & 12,103 & 12,05 & 12,68 & 975 & 12,043 & 12,08 & 12,57 \\
\hline 838 & 12,106 & 12,06 & 12,71 & 907 & 12,103 & 12,06 & 12,69 & 976 & 12,043 & 12,08 & 12,54 \\
\hline 839 & 12,106 & 12,05 & 12,72 & 908 & 12,103 & 12,06 & 12,68 & 977 & 12,043 & 12,06 & 12,53 \\
\hline 840 & 12,106 & 12,07 & 12,72 & 909 & 12,103 & 12,06 & 12,65 & 978 & 12,043 & 12,05 & 12,52 \\
\hline 841 & 12,106 & 12,09 & 12,71 & 910 & 12,103 & 12,08 & 12,66 & 979 & 12,043 & 12,05 & 12,49 \\
\hline 842 & 12,038 & 12,09 & 12,70 & 911 & 12,041 & 12,07 & 12,65 & 980 & 12,043 & 12,06 & 12,48 \\
\hline 843 & 12,038 & 12,09 & 12,70 & 912 & 12,041 & 12,05 & 12,66 & 981 & 12,043 & 12,07 & 12,47 \\
\hline 844 & 12,038 & 12,10 & 12,70 & 913 & 12,041 & 12,05 & 12,65 & 982 & 12,043 & 12,08 & 12,48 \\
\hline 845 & 12,038 & 12,09 & 12,70 & 914 & 12,041 & 12,06 & 12,65 & 983 & 12,043 & 12,06 & 12,49 \\
\hline 846 & 12,038 & 12,08 & 12,68 & 915 & 12,041 & 12,07 & 12,67 & 984 & 12,043 & 12,05 & 12,48 \\
\hline 847 & 12,038 & 12,09 & 12,69 & 916 & 12,041 & 12,06 & 12,68 & 985 & 12,100 & 12,03 & 12,47 \\
\hline 848 & 12,038 & 12,10 & 12,70 & 917 & 12,041 & 12,06 & 12,67 & 986 & 12,100 & 12,04 & 12,43 \\
\hline 849 & 12,038 & 12,07 & 12,69 & 918 & 12,041 & 12,08 & 12,66 & 987 & 12,100 & 12,02 & 12,40 \\
\hline 850 & 12,038 & 12,06 & 12,68 & 919 & 12,041 & 12,08 & 12,65 & 988 & 12,100 & 12,05 & 12,39 \\
\hline 851 & 12,038 & 12,07 & 12,68 & 920 & 12,041 & 12,07 & 12,65 & 989 & 12,100 & 12,05 & 12,40 \\
\hline 852 & 12,038 & 12,05 & 12,68 & 921 & 12,041 & 12,06 & 12,68 & 990 & 12,100 & 12,06 & 12,42 \\
\hline 853 & 12,038 & 12,06 & 12,68 & 922 & 12,041 & 12,09 & 12,69 & 991 & 12,100 & 12,06 & 12,41 \\
\hline 854 & 12,105 & 12,06 & 12,69 & 923 & 12,102 & 12,10 & 12,70 & 992 & 12,100 & 12,07 & 12,38 \\
\hline 855 & 12,105 & 12,07 & 12,68 & 924 & 12,102 & 12,09 & 12,68 & 993 & 12,100 & 12,08 & 12,38 \\
\hline 856 & 12,105 & 12,08 & 12,66 & 925 & 12,102 & 12,09 & 12,69 & 994 & 12,100 & 12,07 & 12,37 \\
\hline 857 & 12,105 & 12,08 & 12,63 & 926 & 12,102 & 12,09 & 12,69 & 995 & 12,100 & 12,07 & 12,36 \\
\hline 858 & 12,105 & 12,08 & 12,63 & 927 & 12,102 & 12,07 & 12,68 & 996 & 12,100 & 12,07 & 12,35 \\
\hline 859 & 12,105 & 12,07 & 12,63 & 928 & 12,102 & 12,07 & 12,69 & 997 & 12,100 & 12,08 & 12,35 \\
\hline 860 & 12,105 & 12,08 & 12,66 & 929 & 12,102 & 12,06 & 12,68 & 998 & 12,044 & 12,06 & 12,33 \\
\hline 861 & 12,105 & 12,08 & 12,65 & 930 & 12,102 & 12,05 & 12,68 & 999 & 12,044 & 12,05 & 12,29 \\
\hline 862 & 12,105 & 12,05 & 12,64 & 931 & 12,102 & 12,03 & 12,70 & 1000 & 12,044 & 12,03 & 12,29 \\
\hline 863 & 12,039 & 12,04 & 12,62 & 932 & 12,102 & 12,01 & 12,70 & 1001 & 12,044 & 12,06 & 12,29 \\
\hline 864 & 12,039 & 12,03 & 12,63 & 933 & 12,102 & 12,03 & 12,68 & 1002 & 12,044 & 12,06 & 12,28 \\
\hline 865 & 12,039 & 12,07 & 12,64 & 934 & 12,102 & 12,05 & 12,68 & 1003 & 12,044 & 12,06 & 12,28 \\
\hline 866 & 12,039 & 12,07 & 12,63 & 935 & 12,102 & 12,06 & 12,68 & 1004 & 12,044 & 12,07 & 12,28 \\
\hline 867 & 12,039 & 12,07 & 12,62 & 936 & 12,102 & 12,05 & 12,68 & 1005 & 12,044 & 12,07 & 12,30 \\
\hline 868 & 12,039 & 12,05 & 12,62 & 937 & 12,102 & 12,04 & 12,69 & 1006 & 12,044 & 12,07 & 12,31 \\
\hline 869 & 12,039 & 12,05 & 12,62 & 938 & 12,102 & 12,02 & 12,68 & 1007 & 12,044 & 12,06 & 12,33 \\
\hline 870 & 12,039 & 12,04 & 12,63 & 939 & 12,042 & 12,05 & 12,68 & 1008 & 12,099 & 12,03 & 12,32 \\
\hline 871 & 12,039 & 12,04 & 12,63 & 940 & 12,042 & 12,08 & 12,70 & 1009 & 12,099 & 12,06 & 12,29 \\
\hline 872 & 12,039 & 12,06 & 12,64 & 941 & 12,042 & 12,08 & 12,71 & 1010 & 12,099 & 12,06 & 12,30 \\
\hline 873 & 12,039 & 12,05 & 12,65 & 942 & 12,042 & 12,08 & 12,73 & 1011 & 12,099 & 12,06 & 12,31 \\
\hline 874 & 12,039 & 12,05 & 12,65 & 943 & 12,042 & 12,07 & 12,72 & 1012 & 12,099 & 12,07 & 12,32 \\
\hline 875 & 12,039 & 12,04 & 12,65 & 944 & 12,042 & 12,08 & 12,72 & 1013 & 12,099 & 12,07 & 12,32 \\
\hline 876 & 12,039 & 12,07 & 12,64 & 945 & 12,042 & 12,09 & 12,73 & 1014 & 12,099 & 12,05 & 12,31 \\
\hline 877 & 12,104 & 12,06 & 12,65 & 946 & 12,042 & 12,07 & 12,74 & 1015 & 12,099 & 12,06 & 12,30 \\
\hline 878 & 12,104 & 12,06 & 12,64 & 947 & 12,042 & 12,06 & 12,73 & 1016 & 12,099 & 12,07 & 12,28 \\
\hline 879 & 12,104 & 12,05 & 12,64 & 948 & 12,042 & 12,08 & 12,71 & 1017 & 12,099 & 12,06 & 12,27 \\
\hline 880 & 12,104 & 12,07 & 12,63 & 949 & 12,042 & 12,08 & 12,70 & 1018 & 12,099 & 12,06 & 12,27 \\
\hline 881 & 12,104 & 12,07 & 12,62 & 950 & 12,042 & 12,10 & 12,72 & 1019 & 12,099 & 12,06 & 12,26 \\
\hline 882 & 12,104 & 12,07 & 12,62 & 951 & 12,042 & 12,09 & 12,71 & 1020 & 12,099 & 12,06 & 12,25 \\
\hline 883 & 12,104 & 12,08 & 12,61 & 952 & 12,042 & 12,06 & 12,69 & 1021 & 12,099 & 12,05 & 12,25 \\
\hline 884 & 12,104 & 12,09 & 12,62 & 953 & 12,042 & 12,05 & 12,69 & 1022 & 12,099 & 12,05 & 12,24 \\
\hline 885 & 12,104 & 12,08 & 12,65 & 954 & 12,042 & 12,04 & 12,68 & 1023 & 12,045 & 12,05 & 12,24 \\
\hline 886 & 12,104 & 12,08 & 12,67 & 955 & 12,042 & 12,05 & 12,67 & 1024 & 12,045 & 12,06 & 12,23 \\
\hline 887 & 12,104 & 12,06 & 12,68 & 956 & 12,042 & 12,02 & 12,66 & 1025 & 12,045 & 12,05 & 12,24 \\
\hline 888 & 12,104 & 12,05 & 12,67 & 957 & 12,042 & 12,03 & 12,64 & 1026 & 12,045 & 12,05 & 12,24 \\
\hline 889 & 12,040 & 12,08 & 12,65 & 958 & 12,101 & 12,05 & 12,61 & 1027 & 12,045 & 12,05 & 12,24 \\
\hline
\end{tabular}




\begin{tabular}{|c|c|c|c|c|c|c|c|c|c|c|c|}
\hline Medições & $\begin{array}{c}\text { Qpadrão } \\
\mathrm{m}^{3} / \mathrm{h}\end{array}$ & $\begin{array}{l}Q_{1 F M} \\
\mathrm{~m}^{3} / \mathrm{h}\end{array}$ & $\begin{array}{l}\text { Qvectus } \\
\mathrm{m}^{3} / \mathrm{h}\end{array}$ & Medições & $\begin{array}{l}\text { Qpadrão } \\
\mathrm{m}^{3} / \mathrm{h}\end{array}$ & $\begin{array}{c}Q_{1 F M} \\
m^{3} / h\end{array}$ & $\begin{array}{l}\text { Qvectus } \\
\mathrm{m}^{3} / \mathrm{h}\end{array}$ & Medições & $\begin{array}{l}\text { Qpadrão } \\
\mathrm{m}^{3} / \mathrm{h}\end{array}$ & $\begin{array}{c}Q_{\text {IFM }} \\
\mathrm{m}^{3} / \mathrm{h}\end{array}$ & $\begin{array}{l}\text { Qvectus } \\
\mathrm{m}^{3} / \mathrm{h}\end{array}$ \\
\hline 1235 & 12,092 & 12,05 & 12,82 & 1304 & 12,054 & 12,06 & 13,33 & 1373 & 12,088 & 12,04 & 13,68 \\
\hline 1236 & 12,092 & 12,08 & 12,82 & 1305 & 12,054 & 12,04 & 13,35 & 1374 & 12,088 & 12,04 & 13,68 \\
\hline 1237 & 12,092 & 12,07 & 12,83 & 1306 & 12,054 & 12,03 & 13,36 & 1375 & 12,088 & 12,05 & 13,68 \\
\hline 1238 & 12,092 & 12,07 & 12,84 & 1307 & 12,054 & 12,02 & 13,37 & 1376 & 12,088 & 12,06 & 13,68 \\
\hline 1239 & 12,052 & 12,09 & 12,83 & 1308 & 12,054 & 12,05 & 13,37 & 1377 & 12,088 & 12,07 & 13,69 \\
\hline 1240 & 12,052 & 12,08 & 12,85 & 1309 & 12,054 & 12,06 & 13,37 & 1378 & 12,088 & 12,04 & 13,67 \\
\hline 1241 & 12,052 & 12,06 & 12,87 & 1310 & 12,054 & 12,05 & 13,38 & 1379 & 12,088 & 12,04 & 13,67 \\
\hline 1242 & 12,052 & 12,07 & 12,89 & 1311 & 12,054 & 12,06 & 13,40 & 1380 & 12,088 & 12,05 & 13,67 \\
\hline 1243 & 12,052 & 12,07 & 12,92 & 1312 & 12,054 & 12,06 & 13,42 & 1381 & 12,088 & 12,05 & 13,65 \\
\hline 1244 & 12,052 & 12,07 & 12,93 & 1313 & 12,054 & 12,08 & 13,44 & 1382 & 12,088 & 12,05 & 13,64 \\
\hline 1245 & 12,052 & 12,04 & 12,93 & 1314 & 12,054 & 12,08 & 13,45 & 1383 & 12,088 & 12,05 & 13,63 \\
\hline 1246 & 12,052 & 12,04 & 12,92 & 1315 & 12,054 & 12,06 & 13,47 & 1384 & 12,088 & 12,05 & 13,64 \\
\hline 1247 & 12,052 & 12,05 & 12,95 & 1316 & 12,054 & 12,05 & 13,49 & 1385 & 12,088 & 12,07 & 13,67 \\
\hline 1248 & 12,052 & 12,07 & 12,97 & 1317 & 12,054 & 12,04 & 13,51 & 1386 & 12,088 & 12,06 & 13,67 \\
\hline 1249 & 12,052 & 12,06 & 12,97 & 1318 & 12,054 & 12,05 & 13,51 & 1387 & 12,056 & 12,07 & 13,66 \\
\hline 1250 & 12,052 & 12,04 & 12,98 & 1319 & 12,054 & 12,04 & 13,52 & 1388 & 12,056 & 12,04 & 13,67 \\
\hline 1251 & 12,052 & 12,03 & 12,98 & 1320 & 12,054 & 12,05 & 13,51 & 1389 & 12,056 & 12,03 & 13,66 \\
\hline 1252 & 12,052 & 12,05 & 13,00 & 1321 & 12,054 & 12,03 & 13,50 & 1390 & 12,056 & 12,03 & 13,65 \\
\hline 1253 & 12,052 & 12,05 & 13,02 & 1322 & 12,054 & 12,03 & 13,50 & 1391 & 12,056 & 12,04 & 13,66 \\
\hline 1254 & 12,052 & 12,04 & 13,01 & 1323 & 12,054 & 12,02 & 13,50 & 1392 & 12,056 & 12,06 & 13,66 \\
\hline 1255 & 12,091 & 12,04 & 13,01 & 1324 & 12,054 & 12,03 & 13,51 & 1393 & 12,056 & 12,06 & 13,67 \\
\hline 1256 & 12,091 & 12,03 & 13,01 & 1325 & 12,089 & 12,04 & 13,53 & 1394 & 12,056 & 12,05 & 13,67 \\
\hline 1257 & 12,091 & 12,05 & 12,99 & 1326 & 12,089 & 12,04 & 13,53 & 1395 & 12,056 & 12,03 & 13,67 \\
\hline 1258 & 12,091 & 12,06 & 12,98 & 1327 & 12,089 & 12,06 & 13,53 & 1396 & 12,056 & 12,03 & 13,67 \\
\hline 1259 & 12,091 & 12,08 & 12,99 & 1328 & 12,089 & 12,06 & 13,54 & 1397 & 12,056 & 12,04 & 13,68 \\
\hline 1260 & 12,091 & 12,08 & 13,00 & 1329 & 12,089 & 12,07 & 13,55 & 1398 & 12,056 & 12,05 & 13,67 \\
\hline 1261 & 12,091 & 12,09 & 13,00 & 1330 & 12,089 & 12,06 & 13,56 & 1399 & 12,056 & 12,05 & 13,66 \\
\hline 1262 & 12,091 & 12,09 & 13,01 & 1331 & 12,089 & 12,06 & 13,56 & 1400 & 12,056 & 12,05 & 13,67 \\
\hline 1263 & 12,091 & 12,06 & 13,05 & 1332 & 12,089 & 12,07 & 13,57 & 1401 & 12,056 & 12,06 & 13,67 \\
\hline 1264 & 12,091 & 12,04 & 13,05 & 1333 & 12,089 & 12,07 & 13,59 & 1402 & 12,056 & 12,06 & 13,69 \\
\hline 1265 & 12,053 & 12,02 & 13,04 & 1334 & 12,089 & 12,07 & 13,59 & 1403 & 12,087 & 12,06 & 13,68 \\
\hline 1266 & 12,053 & 12,01 & 13,05 & 1335 & 12,089 & 12,08 & 13,59 & 1404 & 12,087 & 12,06 & 13,67 \\
\hline 1267 & 12,053 & 12,02 & 13,07 & 1336 & 12,089 & 12,05 & 13,60 & 1405 & 12,087 & 12,06 & 13,65 \\
\hline 1268 & 12,053 & 12,04 & 13,07 & 1337 & 12,089 & 12,04 & 13,63 & 1406 & 12,087 & 12,05 & 13,62 \\
\hline 1269 & 12,053 & 12,05 & 13,09 & 1338 & 12,089 & 12,05 & 13,62 & 1407 & 12,087 & 12,04 & 13,62 \\
\hline 1270 & 12,053 & 12,05 & 13,10 & 1339 & 12,089 & 12,07 & 13,62 & 1408 & 12,087 & 12,05 & 13,63 \\
\hline 1271 & 12,053 & 12,06 & 13,12 & 1340 & 12,089 & 12,06 & 13,63 & 1409 & 12,057 & 12,03 & 13,65 \\
\hline 1272 & 12,053 & 12,02 & 13,13 & 1341 & 12,089 & 12,04 & 13,64 & 1410 & 12,057 & 12,04 & 13,66 \\
\hline 1273 & 12,053 & 12,03 & 13,15 & 1342 & 12,089 & 12,02 & 13,66 & 1411 & 12,057 & 12,05 & 13,64 \\
\hline 1274 & 12,053 & 12,03 & 13,17 & 1343 & 12,089 & 12,03 & 13,66 & 1412 & 12,057 & 12,06 & 13,65 \\
\hline 1275 & 12,053 & 12,05 & 13,16 & 1344 & 12,089 & 12,05 & 13,67 & 1413 & 12,057 & 12,06 & 13,67 \\
\hline 1276 & 12,053 & 12,06 & 13,15 & 1345 & 12,089 & 12,05 & 13,65 & 1414 & 12,057 & 12,07 & 13,67 \\
\hline 1277 & 12,053 & 12,07 & 13,16 & 1346 & 12,089 & 12,05 & 13,66 & 1415 & 12,057 & 12,04 & 13,65 \\
\hline 1278 & 12,053 & 12,08 & 13,17 & 1347 & 12,089 & 12,03 & 13,66 & 1416 & 12,057 & 12,02 & 13,61 \\
\hline 1279 & 12,053 & 12,07 & 13,15 & 1348 & 12,089 & 12,04 & 13,64 & 1417 & 12,057 & 12,03 & 13,59 \\
\hline 1280 & 12,053 & 12,06 & 13,15 & 1349 & 12,089 & 12,06 & 13,63 & 1418 & 12,057 & 12,05 & 13,58 \\
\hline 1281 & 12,053 & 12,06 & 13,17 & 1350 & 12,089 & 12,04 & 13,61 & 1419 & 12,057 & 12,04 & 13,58 \\
\hline 1282 & 12,053 & 12,05 & 13,20 & 1351 & 12,055 & 12,04 & 13,59 & 1420 & 12,057 & 12,03 & 13,56 \\
\hline 1283 & 12,053 & 12,05 & 13,21 & 1352 & 12,055 & 12,06 & 13,57 & 1421 & 12,057 & 12,05 & 13,56 \\
\hline 1284 & 12,053 & 12,06 & 13,22 & 1353 & 12,055 & 12,04 & 13,57 & 1422 & 12,057 & 12,05 & 13,56 \\
\hline 1285 & 12,090 & 12,05 & 13,22 & 1354 & 12,055 & 12,04 & 13,57 & 1423 & 12,057 & 12,05 & 13,57 \\
\hline 1286 & 12,090 & 12,05 & 13,25 & 1355 & 12,055 & 12,04 & 13,57 & 1424 & 12,057 & 12,04 & 13,58 \\
\hline 1287 & 12,090 & 12,03 & 13,26 & 1356 & 12,055 & 12,05 & 13,57 & 1425 & 12,086 & 12,04 & 13,57 \\
\hline 1288 & 12,090 & 12,04 & 13,24 & 1357 & 12,055 & 12,06 & 13,57 & 1426 & 12,086 & 12,06 & 13,57 \\
\hline 1289 & 12,090 & 12,04 & 13,25 & 1358 & 12,055 & 12,06 & 13,58 & 1427 & 12,086 & 12,06 & 13,60 \\
\hline 1290 & 12,090 & 12,06 & 13,28 & 1359 & 12,055 & 12,07 & 13,57 & 1428 & 12,086 & 12,07 & 13,58 \\
\hline 1291 & 12,090 & 12,06 & 13,29 & 1360 & 12,055 & 12,08 & 13,57 & 1429 & 12,086 & 12,07 & 13,60 \\
\hline 1292 & 12,090 & 12,07 & 13,30 & 1361 & 12,055 & 12,08 & 13,58 & 1430 & 12,086 & 12,07 & 13,60 \\
\hline 1293 & 12,090 & 12,06 & 13,33 & 1362 & 12,055 & 12,07 & 13,58 & 1431 & 12,086 & 12,07 & 13,61 \\
\hline 1294 & 12,090 & 12,06 & 13,34 & 1363 & 12,055 & 12,04 & 13,59 & 1432 & 12,086 & 12,05 & 13,59 \\
\hline 1295 & 12,090 & 12,05 & 13,36 & 1364 & 12,055 & 12,04 & 13,58 & 1433 & 12,086 & 12,06 & 13,56 \\
\hline 1296 & 12,090 & 12,05 & 13,37 & 1365 & 12,055 & 12,04 & 13,62 & 1434 & 12,086 & 12,07 & 13,56 \\
\hline 1297 & 12,090 & 12,07 & 13,37 & 1366 & 12,055 & 12,06 & 13,65 & 1435 & 12,086 & 12,07 & 13,54 \\
\hline 1298 & 12,090 & 12,07 & 13,37 & 1367 & 12,055 & 12,05 & 13,66 & 1436 & 12,086 & 12,07 & 13,49 \\
\hline 1299 & 12,090 & 12,07 & 13,36 & 1368 & 12,055 & 12,03 & 13,65 & 1437 & 12,086 & 12,06 & 13,46 \\
\hline 1300 & 12,054 & 12,03 & 13,33 & 1369 & 12,055 & 12,04 & 13,65 & 1438 & 12,086 & 12,04 & 13,46 \\
\hline 1301 & 12,054 & 12,04 & 13,34 & 1370 & 12,055 & 12,07 & 13,67 & 1439 & 12,086 & 12,05 & 13,48 \\
\hline 1302 & 12,054 & 12,06 & 13,35 & 1371 & 12,055 & 12,05 & 13,67 & 1440 & 12,086 & 12,04 & 13,48 \\
\hline 1303 & 12,054 & 12,04 & 13,33 & 1372 & 12,088 & 12,04 & 13,68 & 1441 & 12,086 & 12,03 & 13,48 \\
\hline
\end{tabular}




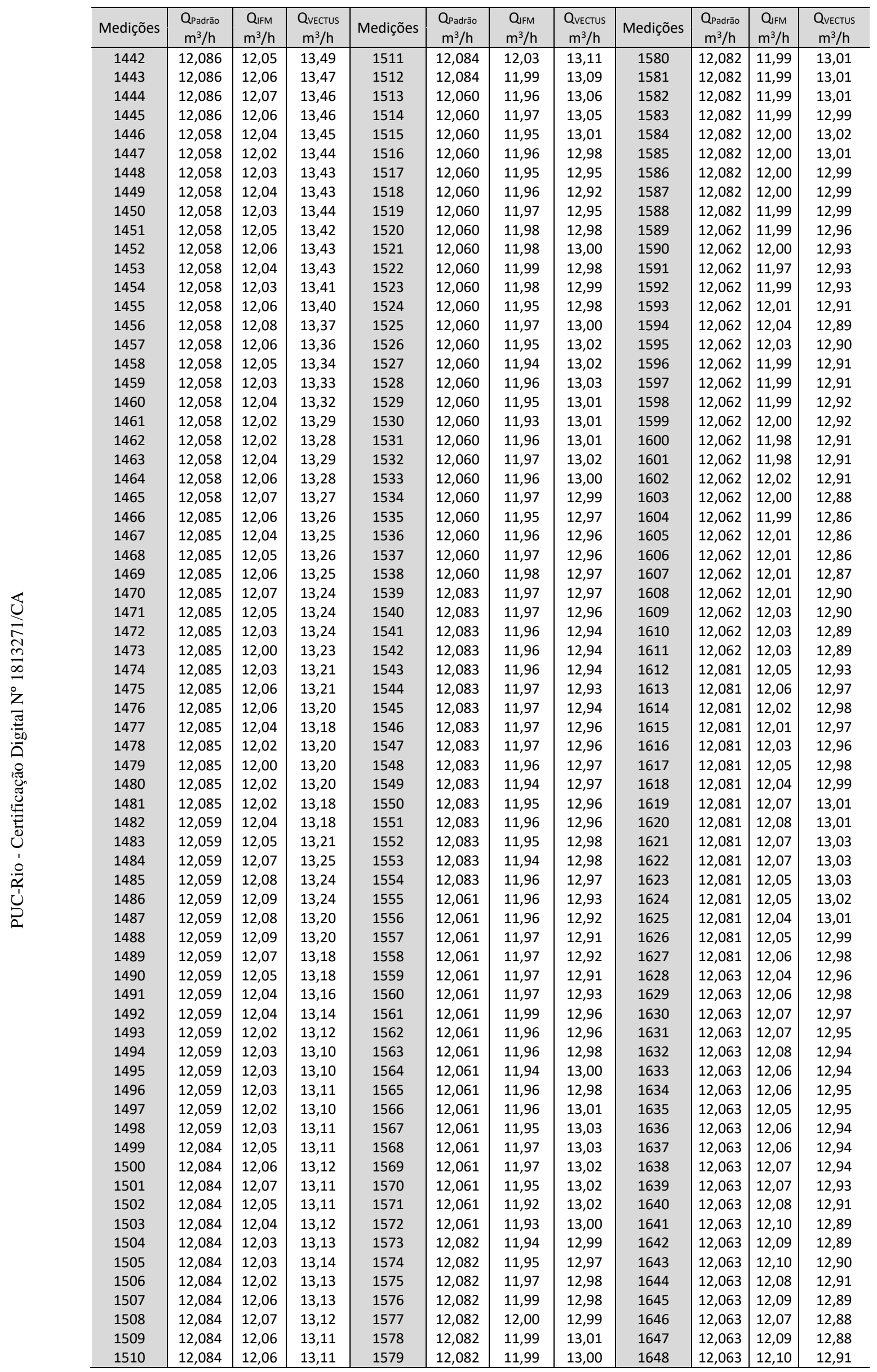




\begin{tabular}{|c|c|c|c|c|c|c|c|c|c|c|c|}
\hline Medições & $\begin{array}{l}\text { Qpadrão } \\
\mathrm{m}^{3} / \mathrm{h}\end{array}$ & $\begin{array}{l}\text { QIFM } \\
\mathrm{m}^{3} / \mathrm{h}\end{array}$ & $\begin{array}{l}\text { Qvectus } \\
\mathrm{m}^{3} / \mathrm{h}\end{array}$ & Medições & $\begin{array}{l}\text { Qpadrão } \\
\mathrm{m}^{3} / \mathrm{h}\end{array}$ & $\begin{array}{l}\text { QIFM } \\
\mathrm{m}^{3} / \mathrm{h}\end{array}$ & $\begin{array}{l}\text { Qvectus } \\
\mathrm{m}^{3} / \mathrm{h}\end{array}$ & Medições & $\begin{array}{l}\text { Qpadrão } \\
\mathrm{m}^{3} / \mathrm{h}\end{array}$ & $\begin{array}{l}\text { Qifm } \\
\mathrm{m}^{3} / \mathrm{h}\end{array}$ & $\begin{array}{l}\text { Qvectus } \\
\mathrm{m}^{3} / \mathrm{h}\end{array}$ \\
\hline 1649 & 12,063 & 12,09 & 12,91 & 1718 & 12,065 & 12,10 & 12,72 & 1787 & 12,077 & 12,05 & 12,33 \\
\hline 1650 & 12,063 & 12,11 & 12,93 & 1719 & 12,065 & 12,09 & 12,70 & 1788 & 12,077 & 12,03 & 12,35 \\
\hline 1651 & 12,080 & 12,10 & 12,94 & 1720 & 12,065 & 12,09 & 12,69 & 1789 & 12,077 & 12,03 & 12,35 \\
\hline 1652 & 12,080 & 12,08 & 12,94 & 1721 & 12,065 & 12,09 & 12,68 & 1790 & 12,077 & 12,05 & 12,35 \\
\hline 1653 & 12,080 & 12,06 & 12,97 & 1722 & 12,065 & 12,09 & 12,65 & 1791 & 12,077 & 12,04 & 12,34 \\
\hline 1654 & 12,080 & 12,07 & 12,95 & 1723 & 12,065 & 12,09 & 12,62 & 1792 & 12,077 & 12,06 & 12,32 \\
\hline 1655 & 12,080 & 12,06 & 12,95 & 1724 & 12,065 & 12,09 & 12,60 & 1793 & 12,077 & 12,07 & 12,35 \\
\hline 1656 & 12,080 & 12,10 & 12,94 & 1725 & 12,065 & 12,07 & 12,57 & 1794 & 12,077 & 12,09 & 12,34 \\
\hline 1657 & 12,080 & 12,10 & 12,95 & 1726 & 12,065 & 12,07 & 12,57 & 1795 & 12,077 & 12,05 & 12,32 \\
\hline 1658 & 12,080 & 12,10 & 12,95 & 1727 & 12,065 & 12,10 & 12,57 & 1796 & 12,077 & 12,05 & 12,31 \\
\hline 1659 & 12,080 & 12,10 & 12,93 & 1728 & 12,065 & 12,11 & 12,57 & 1797 & 12,077 & 12,02 & 12,31 \\
\hline 1660 & 12,080 & 12,10 & 12,92 & 1729 & 12,065 & 12,09 & 12,57 & 1798 & 12,077 & 12,03 & 12,30 \\
\hline 1661 & 12,080 & 12,11 & 12,90 & 1730 & 12,065 & 12,08 & 12,56 & 1799 & 12,077 & 12,05 & 12,28 \\
\hline 1662 & 12,080 & 12,07 & 12,90 & 1731 & 12,065 & 12,09 & 12,53 & 1800 & 12,077 & 12,06 & 12,29 \\
\hline 1663 & 12,080 & 12,08 & 12,87 & 1732 & 12,065 & 12,07 & 12,51 & 1801 & 12,077 & 12,05 & 12,29 \\
\hline 1664 & 12,080 & 12,05 & 12,85 & 1733 & 12,065 & 12,07 & 12,49 & 1802 & 12,077 & 12,07 & 12,29 \\
\hline 1665 & 12,080 & 12,07 & 12,84 & 1734 & 12,065 & 12,07 & 12,50 & 1803 & 12,077 & 12,09 & 12,29 \\
\hline 1666 & 12,080 & 12,09 & 12,84 & 1735 & 12,065 & 12,06 & 12,50 & 1804 & 12,077 & 12,08 & 12,31 \\
\hline 1667 & 12,080 & 12,08 & 12,85 & 1736 & 12,065 & 12,04 & 12,48 & 1805 & 12,077 & 12,07 & 12,32 \\
\hline 1668 & 12,080 & 12,06 & 12,83 & 1737 & 12,065 & 12,02 & 12,47 & 1806 & 12,077 & 12,06 & 12,33 \\
\hline 1669 & 12,080 & 12,08 & 12,83 & 1738 & 12,065 & 12,05 & 12,45 & 1807 & 12,077 & 12,06 & 12,35 \\
\hline 1670 & 12,080 & 12,08 & 12,84 & 1739 & 12,065 & 12,08 & 12,45 & 1808 & 12,077 & 12,10 & 12,35 \\
\hline 1671 & 12,080 & 12,06 & 12,83 & 1740 & 12,065 & 12,05 & 12,46 & 1809 & 12,077 & 12,07 & 12,36 \\
\hline 1672 & 12,080 & 12,07 & 12,83 & 1741 & 12,065 & 12,06 & 12,45 & 1810 & 12,077 & 12,06 & 12,38 \\
\hline 1673 & 12,080 & 12,08 & 12,84 & 1742 & 12,065 & 12,06 & 12,42 & 1811 & 12,077 & 12,06 & 12,38 \\
\hline 1674 & 12,080 & 12,09 & 12,84 & 1743 & 12,065 & 12,07 & 12,41 & 1812 & 12,077 & 12,09 & 12,40 \\
\hline 1675 & 12,064 & 12,09 & 12,84 & 1744 & 12,078 & 12,07 & 12,42 & 1813 & 12,077 & 12,12 & 12,39 \\
\hline 1676 & 12,064 & 12,10 & 12,83 & 1745 & 12,078 & 12,06 & 12,44 & 1814 & 12,077 & 12,11 & 12,37 \\
\hline 1677 & 12,064 & 12,10 & 12,83 & 1746 & 12,078 & 12,07 & 12,44 & 1815 & 12,077 & 12,09 & 12,34 \\
\hline 1678 & 12,064 & 12,10 & 12,84 & 1747 & 12,078 & 12,08 & 12,43 & 1816 & 12,067 & 12,08 & 12,32 \\
\hline 1679 & 12,064 & 12,11 & 12,84 & 1748 & 12,078 & 12,09 & 12,45 & 1817 & 12,067 & 12,11 & 12,29 \\
\hline 1680 & 12,064 & 12,11 & 12,84 & 1749 & 12,078 & 12,07 & 12,46 & 1818 & 12,067 & 12,11 & 12,28 \\
\hline 1681 & 12,064 & 12,10 & 12,83 & 1750 & 12,078 & 12,06 & 12,45 & 1819 & 12,067 & 12,07 & 12,31 \\
\hline 1682 & 12,064 & 12,09 & 12,83 & 1751 & 12,078 & 12,04 & 12,42 & 1820 & 12,067 & 12,07 & 12,30 \\
\hline 1683 & 12,064 & 12,07 & 12,83 & 1752 & 12,078 & 12,03 & 12,38 & 1821 & 12,067 & 12,08 & 12,29 \\
\hline 1684 & 12,064 & 12,09 & 12,82 & 1753 & 12,078 & 12,05 & 12,40 & 1822 & 12,067 & 12,07 & 12,29 \\
\hline 1685 & 12,064 & 12,09 & 12,84 & 1754 & 12,078 & 12,07 & 12,42 & 1823 & 12,067 & 12,06 & 12,30 \\
\hline 1686 & 12,064 & 12,11 & 12,83 & 1755 & 12,078 & 12,08 & 12,43 & 1824 & 12,067 & 12,08 & 12,30 \\
\hline 1687 & 12,064 & 12,12 & 12,84 & 1756 & 12,078 & 12,09 & 12,44 & 1825 & 12,067 & 12,08 & 12,30 \\
\hline 1688 & 12,064 & 12,12 & 12,84 & 1757 & 12,078 & 12,08 & 12,42 & 1826 & 12,067 & 12,09 & 12,29 \\
\hline 1689 & 12,064 & 12,11 & 12,84 & 1758 & 12,078 & 12,08 & 12,40 & 1827 & 12,067 & 12,10 & 12,31 \\
\hline 1690 & 12,064 & 12,09 & 12,83 & 1759 & 12,078 & 12,07 & 12,39 & 1828 & 12,067 & 12,07 & 12,33 \\
\hline 1691 & 12,064 & 12,11 & 12,84 & 1760 & 12,078 & 12,06 & 12,38 & 1829 & 12,067 & 12,09 & 12,31 \\
\hline 1692 & 12,064 & 12,10 & 12,86 & 1761 & 12,078 & 12,08 & 12,38 & 1830 & 12,067 & 12,10 & 12,34 \\
\hline 1693 & 12,064 & 12,10 & 12,86 & 1762 & 12,078 & 12,08 & 12,38 & 1831 & 12,067 & 12,11 & 12,34 \\
\hline 1694 & 12,079 & 12,12 & 12,84 & 1763 & 12,078 & 12,08 & 12,40 & 1832 & 12,067 & 12,09 & 12,36 \\
\hline 1695 & 12,079 & 12,09 & 12,83 & 1764 & 12,078 & 12,08 & 12,40 & 1833 & 12,067 & 12,06 & 12,36 \\
\hline 1696 & 12,079 & 12,05 & 12,80 & 1765 & 12,078 & 12,09 & 12,41 & 1834 & 12,067 & 12,08 & 12,34 \\
\hline 1697 & 12,079 & 12,10 & 12,81 & 1766 & 12,066 & 12,08 & 12,43 & 1835 & 12,067 & 12,10 & 12,33 \\
\hline 1698 & 12,079 & 12,11 & 12,82 & 1767 & 12,066 & 12,06 & 12,43 & 1836 & 12,067 & 12,11 & 12,32 \\
\hline 1699 & 12,079 & 12,09 & 12,81 & 1768 & 12,066 & 12,07 & 12,44 & 1837 & 12,067 & 12,09 & 12,32 \\
\hline 1700 & 12,079 & 12,09 & 12,77 & 1769 & 12,066 & 12,07 & 12,44 & 1838 & 12,067 & 12,09 & 12,31 \\
\hline 1701 & 12,079 & 12,09 & 12,74 & 1770 & 12,066 & 12,09 & 12,45 & 1839 & 12,067 & 12,09 & 12,31 \\
\hline 1702 & 12,079 & 12,08 & 12,71 & 1771 & 12,066 & 12,08 & 12,46 & 1840 & 12,067 & 12,09 & 12,32 \\
\hline 1703 & 12,079 & 12,07 & 12,71 & 1772 & 12,066 & 12,08 & 12,45 & 1841 & 12,067 & 12,10 & 12,34 \\
\hline 1704 & 12,079 & 12,07 & 12,72 & 1773 & 12,066 & 12,07 & 12,42 & 1842 & 12,067 & 12,09 & 12,34 \\
\hline 1705 & 12,079 & 12,07 & 12,72 & 1774 & 12,066 & 12,06 & 12,40 & 1843 & 12,067 & 12,11 & 12,34 \\
\hline 1706 & 12,079 & 12,10 & 12,71 & 1775 & 12,066 & 12,05 & 12,39 & 1844 & 12,076 & 12,12 & 12,37 \\
\hline 1707 & 12,079 & 12,10 & 12,72 & 1776 & 12,066 & 12,03 & 12,38 & 1845 & 12,076 & 12,11 & 12,37 \\
\hline 1708 & 12,079 & 12,11 & 12,71 & 1777 & 12,066 & 12,04 & 12,37 & 1846 & 12,076 & 12,11 & 12,35 \\
\hline 1709 & 12,079 & 12,11 & 12,71 & 1778 & 12,066 & 12,04 & 12,36 & 1847 & 12,076 & 12,10 & 12,33 \\
\hline 1710 & 12,079 & 12,11 & 12,71 & 1779 & 12,066 & 12,06 & 12,37 & 1848 & 12,076 & 12,06 & 12,30 \\
\hline 1711 & 12,079 & 12,07 & 12,72 & 1780 & 12,066 & 12,08 & 12,36 & 1849 & 12,076 & 12,08 & 12,27 \\
\hline 1712 & 12,079 & 12,08 & 12,73 & 1781 & 12,066 & 12,08 & 12,37 & 1850 & 12,076 & 12,09 & 12,28 \\
\hline 1713 & 12,079 & 12,08 & 12,74 & 1782 & 12,066 & 12,05 & 12,35 & 1851 & 12,076 & 12,08 & 12,31 \\
\hline 1714 & 12,079 & 12,06 & 12,72 & 1783 & 12,066 & 12,04 & 12,32 & 1852 & 12,076 & 12,06 & 12,32 \\
\hline 1715 & 12,079 & 12,08 & 12,71 & 1784 & 12,066 & 12,06 & 12,32 & 1853 & 12,076 & 12,06 & 12,31 \\
\hline 1716 & 12,079 & 12,12 & 12,71 & 1785 & 12,066 & 12,08 & 12,33 & 1854 & 12,076 & 12,06 & 12,29 \\
\hline 1717 & 12,065 & 12,11 & 12,71 & 1786 & 12,066 & 12,07 & 12,32 & 1855 & 12,076 & 12,05 & 12,27 \\
\hline
\end{tabular}




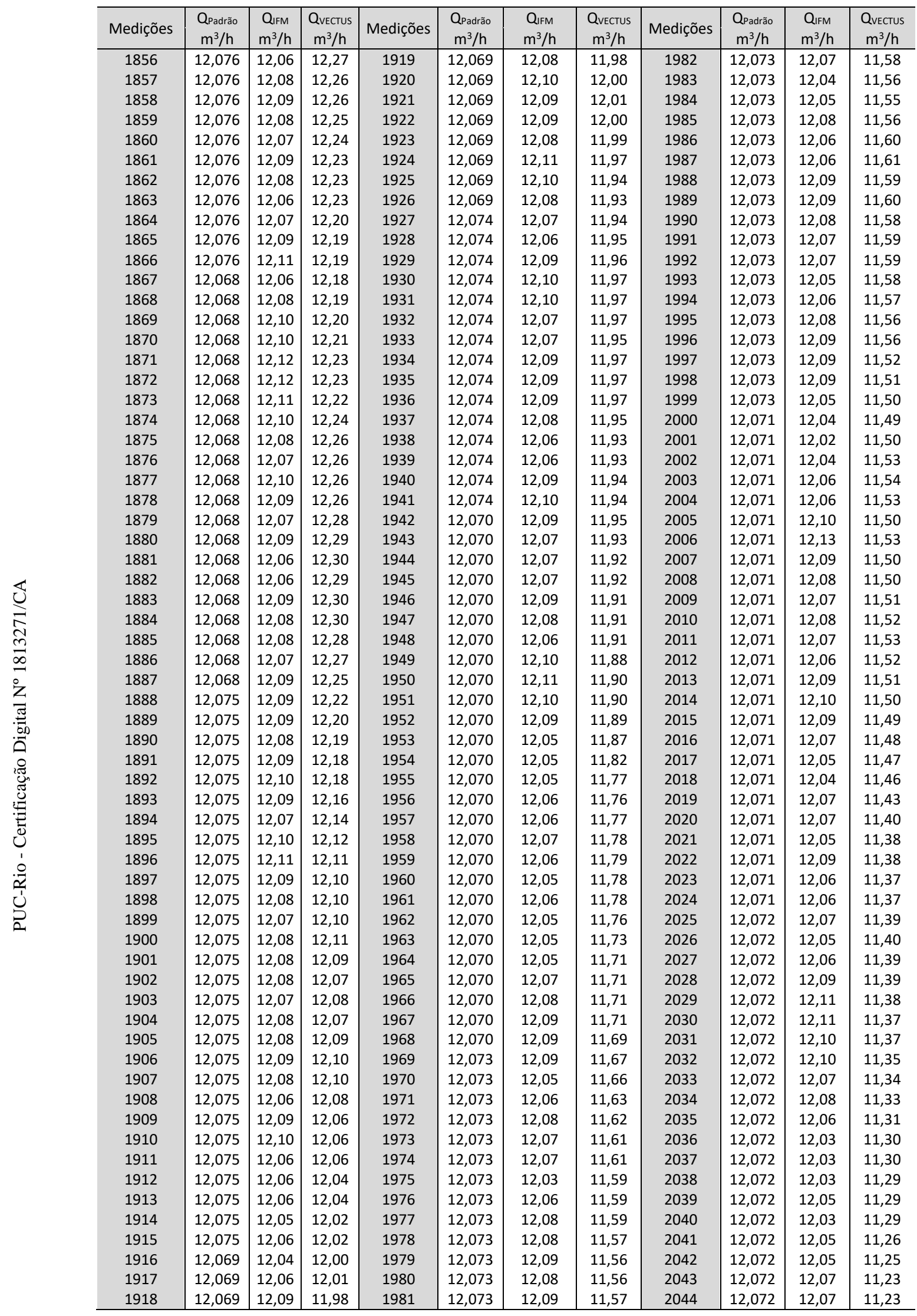


Tabela 31 - Dados obtidos com o rotor da bomba hidráulica girando na frequência de $45 \mathrm{~Hz}$

\begin{tabular}{|c|c|c|c|c|c|c|c|c|c|c|c|}
\hline & & & bela com & $\begin{array}{l}\text { Jados obti } \\
\text { todos valo }\end{array}$ & $\begin{array}{l}\text { Jos na fr } \\
\text { res med }\end{array}$ & $\begin{array}{l}\text { quênci } \\
\text { os (Inc }\end{array}$ & $\begin{array}{l}\text { de } 45 \mathrm{~Hz} \\
\text { ui possív }\end{array}$ & eis outliers & & & \\
\hline Medições & $\begin{array}{c}\text { Qpadrão } \\
\mathrm{m}^{3} / \mathrm{h}\end{array}$ & $\begin{array}{l}\text { QIFM } \\
\mathrm{m}^{3} / \mathrm{h}\end{array}$ & $\begin{array}{c}\text { Qvectus } \\
\mathrm{m}^{3} / \mathrm{h}\end{array}$ & Medições & $\begin{array}{c}\text { Qpadrão } \\
\mathrm{m}^{3} / \mathrm{h}\end{array}$ & $\begin{array}{l}\text { QIFM } \\
\mathrm{m}^{3} / \mathrm{h}\end{array}$ & $\begin{array}{c}\text { QVectus } \\
\mathrm{m}^{3} / \mathrm{h}\end{array}$ & Medições & $\begin{array}{c}\text { Qpadrão } \\
\mathrm{m}^{3} / \mathrm{h}\end{array}$ & $\begin{array}{l}\text { QIFM } \\
\mathrm{m}^{3} / \mathrm{h}\end{array}$ & $\begin{array}{c}\text { QVectus } \\
\mathrm{m}^{3} / \mathrm{h}\end{array}$ \\
\hline 1 & 10,975 & 10,99 & 10,42 & 21 & 10,971 & 10,99 & 10,40 & 41 & 10,954 & 10,96 & 10,27 \\
\hline 2 & 10,970 & 10,99 & 10,43 & 22 & 10,969 & 10,98 & 10,42 & 42 & 10,950 & 10,95 & 10,25 \\
\hline 3 & 10,970 & 11,00 & 10,43 & 23 & 10,964 & 10,95 & 10,41 & 43 & 10,943 & 10,96 & 10,23 \\
\hline 4 & 10,974 & 10,99 & 10,43 & 24 & 10,958 & 10,96 & 10,39 & 44 & 10,940 & 10,98 & 10,23 \\
\hline 5 & 10,984 & 10,98 & 10,42 & 25 & 10,955 & 10,97 & 10,40 & 45 & 10,939 & 10,98 & 10,21 \\
\hline 6 & 10,987 & 10,98 & 10,42 & 26 & 10,956 & 10,98 & 10,39 & 46 & 10,942 & 10,97 & 10,21 \\
\hline 7 & 10,986 & 10,99 & 10,40 & 27 & 10,958 & 10,98 & 10,37 & 47 & 10,946 & 10,96 & 10,20 \\
\hline 8 & 10,982 & 10,98 & 10,41 & 28 & 10,956 & 10,98 & 10,35 & 48 & 10,946 & 10,93 & 10,22 \\
\hline 9 & 10,978 & 10,97 & 10,41 & 29 & 10,953 & 10,98 & 10,34 & 49 & 10,944 & 10,90 & 10,23 \\
\hline 10 & 10,976 & 10,97 & 10,40 & 30 & 10,951 & 10,97 & 10,34 & 50 & 10,939 & 10,93 & 10,24 \\
\hline 11 & 10,976 & 10,97 & 10,41 & 31 & 10,950 & 10,97 & 10,32 & 51 & 10,933 & 10,96 & 10,28 \\
\hline 12 & 10,972 & 10,95 & 10,41 & 32 & 10,953 & 10,93 & 10,32 & 52 & 10,925 & 10,99 & 10,31 \\
\hline 13 & 10,970 & 10,94 & 10,42 & 33 & 10,958 & 10,93 & 10,29 & 53 & 10,926 & 10,96 & 10,32 \\
\hline 14 & 10,969 & 10,94 & 10,42 & 34 & 10,963 & 10,95 & 10,24 & 54 & 10,926 & 10,96 & 10,31 \\
\hline 15 & 10,962 & 10,97 & 10,42 & 35 & 10,971 & 10,95 & 10,24 & 55 & 10,923 & 10,95 & 10,30 \\
\hline 16 & 10,955 & 10,99 & 10,42 & 36 & 10,977 & 10,97 & 10,26 & 56 & 10,923 & 10,95 & 10,28 \\
\hline 17 & 10,959 & 11,00 & 10,43 & 37 & 10,981 & 10,97 & 10,27 & 57 & 10,928 & 10,98 & 10,27 \\
\hline 18 & 10,969 & 11,00 & 10,43 & 38 & 10,977 & 10,95 & 10,29 & 58 & 10,936 & 10,98 & 10,28 \\
\hline 19 & 10,972 & 10,98 & 10,42 & 39 & 10,968 & 10,92 & 10,29 & 59 & 10,945 & 10,96 & 10,28 \\
\hline 20 & 10,969 & 10,99 & 10,40 & 40 & 10,960 & 10,94 & 10,28 & 60 & 10,948 & 10,95 & 10,28 \\
\hline : & : & : & : & : & : & : & : & : & : & : & : \\
\hline : & : & : & : & : & : & : & : & : & : & : & : \\
\hline : & : & : & : & : & : & : & : & : & : & : & : \\
\hline 2215 & 10,748 & 10,74 & 11,90 & 2243 & 10,690 & 10,73 & 11,88 & 2271 & 10,704 & 10,72 & 11,84 \\
\hline 2216 & 10,748 & 10,70 & 11,91 & 2244 & 10,690 & 10,73 & 11,90 & 2272 & 10,713 & 10,73 & 11,86 \\
\hline 2217 & 10,743 & 10,71 & 11,92 & 2245 & 10,690 & 10,74 & 11,89 & 2273 & 10,720 & 10,73 & 11,86 \\
\hline 2218 & 10,740 & 10,72 & 11,90 & 2246 & 10,695 & 10,75 & 11,89 & 2274 & 10,717 & 10,71 & 11,83 \\
\hline 2219 & 10,740 & 10,73 & 11,91 & 2247 & 10,702 & 10,74 & 11,90 & 2275 & 10,710 & 10,73 & 11,83 \\
\hline 2220 & 10,748 & 10,72 & 11,90 & 2248 & 10,709 & 10,71 & 11,90 & 2276 & 10,707 & 10,73 & 11,79 \\
\hline 2221 & 10,750 & 10,74 & 11,90 & 2249 & 10,713 & 10,71 & 11,89 & 2277 & 10,707 & 10,72 & 11,79 \\
\hline 2222 & 10,741 & 10,72 & 11,91 & 2250 & 10,716 & 10,70 & 11,91 & 2278 & 10,707 & 10,69 & 11,79 \\
\hline 2223 & 10,733 & 10,71 & 11,90 & 2251 & 10,712 & 10,70 & 11,91 & 2279 & 10,710 & 10,68 & 11,80 \\
\hline 2224 & 10,725 & 10,70 & 11,91 & 2252 & 10,705 & 10,69 & 11,89 & 2280 & 10,712 & 10,71 & 11,78 \\
\hline 2225 & 10,719 & 10,71 & 11,92 & 2253 & 10,701 & 10,70 & 11,90 & 2281 & 10,710 & 10,72 & 11,79 \\
\hline 2226 & 10,719 & 10,72 & 11,93 & 2254 & 10,704 & 10,72 & 11,90 & 2282 & 10,707 & 10,70 & 11,77 \\
\hline 2227 & 10,714 & 10,71 & 11,92 & 2255 & 10,709 & 10,70 & 11,90 & 2283 & 10,701 & 10,70 & 11,76 \\
\hline 2228 & 10,713 & 10,71 & 11,91 & 2256 & 10,718 & 10,71 & 11,91 & 2284 & 10,691 & 10,71 & 11,76 \\
\hline 2229 & 10,712 & 10,74 & 11,92 & 2257 & 10,722 & 10,70 & 11,90 & 2285 & 10,687 & 10,72 & 11,76 \\
\hline 2230 & 10,713 & 10,67 & 11,93 & 2258 & 10,726 & 10,72 & 11,89 & 2286 & 10,686 & 10,74 & 11,78 \\
\hline 2231 & 10,713 & 10,65 & 11,90 & 2259 & 10,729 & 10,71 & 11,88 & 2287 & 10,689 & 10,72 & 11,80 \\
\hline 2232 & 10,713 & 10,68 & 11,87 & 2260 & 10,735 & 10,71 & 11,87 & 2288 & 10,688 & 10,73 & 11,79 \\
\hline 2233 & 10,708 & 10,68 & 11,85 & 2261 & 10,734 & 10,70 & 11,86 & 2289 & 10,689 & 10,74 & 11,75 \\
\hline 2234 & 10,700 & 10,70 & 11,85 & 2262 & 10,729 & 10,71 & 11,88 & 2290 & 10,687 & 10,74 & 11,75 \\
\hline 2235 & 10,693 & 10,70 & 11,87 & 2263 & 10,717 & 10,70 & 11,90 & 2291 & 10,689 & 10,72 & 11,75 \\
\hline 2236 & 10,683 & 10,70 & 11,86 & 2264 & 10,705 & 10,69 & 11,87 & 2292 & 10,692 & 10,71 & 11,76 \\
\hline 2237 & 10,681 & 10,73 & 11,88 & 2265 & 10,695 & 10,69 & 11,84 & 2293 & 10,692 & 10,70 & 11,76 \\
\hline 2238 & 10,684 & 10,72 & 11,90 & 2266 & 10,690 & 10,67 & 11,83 & 2294 & 10,694 & 10,70 & 11,76 \\
\hline 2239 & 10,686 & 10,71 & 11,91 & 2267 & 10,686 & 10,69 & 11,85 & 2295 & 10,698 & 10,72 & 11,74 \\
\hline 2240 & 10,689 & 10,72 & 11,90 & 2268 & 10,691 & 10,71 & 11,83 & 2296 & 10,706 & 10,70 & 11,71 \\
\hline 2241 & 10,691 & 10,71 & 11,90 & 2269 & 10,698 & 10,70 & 11,82 & 2297 & 10,715 & 10,70 & 11,70 \\
\hline 2242 & 10,690 & 10,71 & 11,89 & 2270 & 10,700 & 10,73 & 11,83 & 2298 & 10,711 & 10,71 & 11,70 \\
\hline
\end{tabular}


Tabela 32 - Dados obtidos com o rotor da bomba hidráulica girando na frequência de $40 \mathrm{~Hz}$

\begin{tabular}{|c|c|c|c|c|c|c|c|c|c|c|c|}
\hline & & & bela com & $\begin{array}{l}\text { Jados obti } \\
\text { todos valo }\end{array}$ & $\begin{array}{l}\text { Ios na fr } \\
\text { res med }\end{array}$ & os (In & $\begin{array}{l}\text { de } 40 \mathrm{~Hz} \\
\text { ui possív }\end{array}$ & $\begin{array}{l}\text { eis outliers } \\
\text { eis }\end{array}$ & & & \\
\hline Medições & $\begin{array}{c}\text { Qpadrão } \\
\mathrm{m}^{3} / \mathrm{h}\end{array}$ & $\begin{array}{l}\text { QIFM } \\
\mathrm{m}^{3} / \mathrm{h}\end{array}$ & $\begin{array}{c}\text { Qvectus } \\
\mathrm{m}^{3} / \mathrm{h}\end{array}$ & Medições & $\begin{array}{c}\text { Qpadrão } \\
\mathrm{m}^{3} / \mathrm{h}\end{array}$ & $\begin{array}{l}\text { QIFM } \\
\mathrm{m}^{3} / \mathrm{h}\end{array}$ & $\begin{array}{c}\text { QVectus } \\
\mathrm{m}^{3} / \mathrm{h}\end{array}$ & Medições & $\begin{array}{c}\text { Qpadrão } \\
\mathrm{m}^{3} / \mathrm{h}\end{array}$ & $\begin{array}{l}\text { QIFM } \\
\mathrm{m}^{3} / \mathrm{h}\end{array}$ & $\begin{array}{c}\text { Qvectus } \\
\mathrm{m}^{3} / \mathrm{h}\end{array}$ \\
\hline 1 & 9,522 & 9,52 & 10,53 & 21 & 9,553 & 9,49 & 10,91 & 41 & 9,544 & 9,51 & 10,96 \\
\hline 2 & 9,525 & 9,52 & 10,58 & 22 & 9,553 & 9,51 & 10,91 & 42 & 9,535 & 9,51 & 10,96 \\
\hline 3 & 9,523 & 9,53 & 10,61 & 23 & 9,543 & 9,52 & 10,92 & 43 & 9,514 & 9,51 & 10,96 \\
\hline 4 & 9,536 & 9,53 & 10,66 & 24 & 9,532 & 9,52 & 10,91 & 44 & 9,498 & 9,51 & 10,94 \\
\hline 5 & 9,537 & 9,53 & 10,68 & 25 & 9,541 & 9,52 & 10,90 & 45 & 9,514 & 9,50 & 10,90 \\
\hline 6 & 9,514 & 9,53 & 10,70 & 26 & 9,547 & 9,52 & 10,93 & 46 & 9,529 & 9,50 & 10,89 \\
\hline 7 & 9,504 & 9,52 & 10,72 & 27 & 9,519 & 9,52 & 10,94 & 47 & 9,549 & 9,50 & 10,88 \\
\hline 8 & 9,526 & 9,52 & 10,73 & 28 & 9,523 & 9,52 & 10,94 & 48 & 9,519 & 9,51 & 10,86 \\
\hline 9 & 9,519 & 9,52 & 10,75 & 29 & 9,531 & 9,52 & 10,95 & 49 & 9,507 & 9,51 & 10,86 \\
\hline 10 & 9,532 & 9,52 & 10,76 & 30 & 9,543 & 9,52 & 10,96 & 50 & 9,52 & 9,51 & 10,87 \\
\hline 11 & 9,540 & 9,51 & 10,80 & 31 & 9,545 & 9,52 & 10,96 & 51 & 9,517 & 9,51 & 10,87 \\
\hline 12 & 9,545 & 9,50 & 10,83 & 32 & 9,533 & 9,53 & 10,95 & 52 & 9,521 & 9,51 & 10,89 \\
\hline 13 & 9,531 & 9,50 & 10,84 & 33 & 9,529 & 9,52 & 10,94 & 53 & 9,522 & 9,51 & 10,91 \\
\hline 14 & 9,553 & 9,50 & 10,86 & 34 & 9,538 & 9,52 & 10,95 & 54 & 9,518 & 9,51 & 10,89 \\
\hline 15 & 9,559 & 9,49 & 10,86 & 35 & 9,540 & 9,51 & 10,95 & 55 & 9,512 & 9,51 & 10,89 \\
\hline 16 & 9,562 & 9,49 & 10,85 & 36 & 9,524 & 9,51 & 10,95 & 56 & 9,528 & 9,52 & 10,89 \\
\hline 17 & 9,546 & 9,49 & 10,85 & 37 & 9,517 & 9,51 & 10,96 & 57 & 9,528 & 9,53 & 10,90 \\
\hline 18 & 9,528 & 9,49 & 10,86 & 38 & 9,515 & 9,51 & 10,95 & 58 & 9,518 & 9,54 & 10,91 \\
\hline 19 & 9,535 & 9,49 & 10,87 & 39 & 9,505 & 9,51 & 10,94 & 59 & 9,517 & 9,55 & 10,89 \\
\hline 20 & 9,556 & 9,49 & 10,88 & 40 & 9,539 & 9,51 & 10,94 & 60 & 9,530 & 9,55 & 10,89 \\
\hline : & : & : & : & : & : & : & : & : & : & : & : \\
\hline : & : & : & : & : & : & : & : & : & : & : & : \\
\hline : & : & : & : & : & : & : & : & : & : & : & : \\
\hline 1536 & 9,757 & 9,75 & 9,73 & 1564 & 9,744 & 9,77 & 9,76 & 1592 & 9,752 & 9,76 & 9,75 \\
\hline 1537 & 9,758 & 9,75 & 9,73 & 1565 & 9,739 & 9,77 & 9,75 & 1593 & 9,751 & 9,76 & 9,74 \\
\hline 1538 & 9,763 & 9,75 & 9,74 & 1566 & 9,731 & 9,76 & 9,74 & 1594 & 9,762 & 9,76 & 9,76 \\
\hline 1539 & 9,764 & 9,76 & 9,73 & 1567 & 9,745 & 9,76 & 9,74 & 1595 & 9,766 & 9,77 & 9,77 \\
\hline 1540 & 9,765 & 9,76 & 9,75 & 1568 & 9,764 & 9,76 & 9,77 & 1596 & 9,771 & 9,77 & 9,77 \\
\hline 1541 & 9,762 & 9,76 & 9,72 & 1569 & 9,777 & 9,76 & 9,79 & 1597 & 9,782 & 9,77 & 9,77 \\
\hline 1542 & 9,762 & 9,76 & 9,76 & 1570 & 9,773 & 9,75 & 9,81 & 1598 & 9,781 & 9,77 & 9,76 \\
\hline 1543 & 9,764 & 9,76 & 9,76 & 1571 & 9,752 & 9,75 & 9,81 & 1599 & 9,773 & 9,77 & 9,80 \\
\hline 1544 & 9,762 & 9,76 & 9,78 & 1572 & 9,757 & 9,75 & 9,80 & 1600 & 9,777 & 9,76 & 9,81 \\
\hline 1545 & 9,77 & 9,75 & 9,80 & 1573 & 9,762 & 9,75 & 9,81 & 1601 & 9,783 & 9,77 & 9,82 \\
\hline 1546 & 9,763 & 9,75 & 9,80 & 1574 & 9,760 & 9,75 & 9,81 & 1602 & 9,771 & 9,77 & 9,84 \\
\hline 1547 & 9,765 & 9,75 & 9,80 & 1575 & 9,762 & 9,75 & 9,80 & 1603 & 9,767 & 9,77 & 9,85 \\
\hline 1548 & 9,772 & 9,75 & 9,82 & 1576 & 9,767 & 9,75 & 9,79 & 1604 & 9,769 & 9,78 & 9,84 \\
\hline 1549 & 9,763 & 9,75 & 9,81 & 1577 & 9,757 & 9,75 & 9,77 & 1605 & 9,762 & 9,79 & 9,84 \\
\hline 1550 & 9,752 & 9,76 & 9,79 & 1578 & 9,753 & 9,76 & 9,75 & 1606 & 9,759 & 9,79 & 9,83 \\
\hline 1551 & 9,756 & 9,76 & 9,78 & 1579 & 9,763 & 9,76 & 9,74 & 1607 & 9,743 & 9,78 & 9,82 \\
\hline 1552 & 9,754 & 9,76 & 9,76 & 1580 & 9,752 & 9,76 & 9,74 & 1608 & 9,754 & 9,77 & 9,82 \\
\hline 1553 & 9,753 & 9,76 & 9,77 & 1581 & 9,763 & 9,75 & 9,78 & 1609 & 9,772 & 9,76 & 9,82 \\
\hline 1554 & 9,752 & 9,76 & 9,80 & 1582 & 9,764 & 9,75 & 9,82 & 1610 & 9,761 & 9,77 & 9,82 \\
\hline 1555 & 9,752 & 9,76 & 9,81 & 1583 & 9,761 & 9,75 & 9,83 & 1611 & 9,753 & 9,77 & 9,81 \\
\hline 1556 & 9,768 & 9,77 & 9,81 & 1584 & 9,767 & 9,75 & 9,83 & 1612 & 9,751 & 9,77 & 9,81 \\
\hline 1557 & 9,764 & 9,77 & 9,80 & 1585 & 9,761 & 9,75 & 9,83 & 1613 & 9,751 & 9,77 & 9,81 \\
\hline 1558 & 9,757 & 9,77 & 9,81 & 1586 & 9,750 & 9,75 & 9,84 & 1614 & 9,768 & 9,77 & 9,79 \\
\hline 1559 & 9,770 & 9,77 & 9,80 & 1587 & 9,756 & 9,74 & 9,79 & 1615 & 9,770 & 9,77 & 9,80 \\
\hline 1560 & 9,755 & 9,78 & 9,79 & 1588 & 9,763 & 9,74 & 9,76 & 1616 & 9,773 & 9,77 & 9,80 \\
\hline 1561 & 9,755 & 9,78 & 9,79 & 1589 & 9,770 & 9,74 & 9,77 & 1617 & 9,786 & 9,77 & 9,80 \\
\hline 1562 & 9,771 & 9,77 & 9,76 & 1590 & 9,788 & 9,75 & 9,77 & 1618 & 9,773 & 9,78 & 9,81 \\
\hline 1563 & 9,766 & 9,77 & 9,76 & 1591 & 9,760 & 9,76 & 9,75 & 1619 & 9,767 & 9,77 & 9,85 \\
\hline
\end{tabular}


Tabela 33 - Dados obtidos com o rotor da bomba hidráulica girando na frequência de $35 \mathrm{~Hz}$

\begin{tabular}{|c|c|c|c|c|c|c|c|c|c|c|c|}
\hline & & & bela com & $\begin{array}{l}\text { Jados obti } \\
\text { todos valo }\end{array}$ & $\begin{array}{l}\text { Ios na fr } \\
\text { res med }\end{array}$ & $\begin{array}{l}\text { uênc } \\
\text { os (In }\end{array}$ & $\begin{array}{l}\text { de } 35 \mathrm{~Hz} \\
\text { ui possív }\end{array}$ & $\begin{array}{l}\text { eis outliers } \\
\text { es }\end{array}$ & & & \\
\hline Medições & $\begin{array}{c}\text { Qpadrão } \\
\mathrm{m}^{3} / \mathrm{h}\end{array}$ & $\begin{array}{l}\text { QIFM } \\
\mathrm{m}^{3} / \mathrm{h}\end{array}$ & $\begin{array}{c}\text { QVectus } \\
\mathrm{m}^{3} / \mathrm{h}\end{array}$ & Medições & $\begin{array}{c}\text { Qpadrão } \\
\mathrm{m}^{3} / \mathrm{h}\end{array}$ & $\begin{array}{l}\text { QIFM } \\
\mathrm{m}^{3} / \mathrm{h}\end{array}$ & $\begin{array}{c}\text { QVectus } \\
\mathrm{m}^{3} / \mathrm{h}\end{array}$ & Medições & $\begin{array}{c}\text { Qpadrão } \\
\mathrm{m}^{3} / \mathrm{h}\end{array}$ & $\begin{array}{l}\text { QIFM } \\
\mathrm{m}^{3} / \mathrm{h}\end{array}$ & $\begin{array}{l}\text { QVectus } \\
\mathrm{m}^{3} / \mathrm{h}\end{array}$ \\
\hline 1 & 7,049 & 7,04 & 6,51 & 21 & 7,055 & 7,03 & 6,70 & 41 & 7,054 & 7,11 & 6,64 \\
\hline 2 & 7,047 & 7,04 & 6,52 & 22 & 7,059 & 7,05 & 6,68 & 42 & 7,059 & 7,09 & 6,62 \\
\hline 3 & 7,042 & 7,06 & 6,51 & 23 & 7,063 & 7,07 & 6,69 & 43 & 7,061 & 7,06 & 6,62 \\
\hline 4 & 7,04 & 7,06 & 6,52 & 24 & 7,069 & 7,08 & 6,69 & 44 & 7,062 & 7,05 & 6,62 \\
\hline 5 & 7,042 & 7,06 & 6,53 & 25 & 7,075 & 7,07 & 6,72 & 45 & 7,06 & 7,04 & 6,63 \\
\hline 6 & 7,053 & 7,07 & 6,57 & 26 & 7,077 & 7,07 & 6,74 & 46 & 7,056 & 7,06 & 6,62 \\
\hline 7 & 7,067 & 7,06 & 6,61 & 27 & 7,078 & 7,07 & 6,74 & 47 & 7,053 & 7,09 & 6,63 \\
\hline 8 & 7,080 & 7,06 & 6,61 & 28 & 7,076 & 7,07 & 6,74 & 48 & 7,053 & 7,08 & 6,63 \\
\hline 9 & 7,086 & 7,06 & 6,59 & 29 & 7,075 & 7,06 & 6,74 & 49 & 7,052 & 7,06 & 6,62 \\
\hline 10 & 7,088 & 7,06 & 6,58 & 30 & 7,077 & 7,07 & 6,73 & 50 & 7,05 & 7,06 & 6,59 \\
\hline 11 & 7,086 & 7,05 & 6,59 & 31 & 7,078 & 7,08 & 6,71 & 51 & 7,049 & 7,06 & 6,58 \\
\hline 12 & 7,079 & 7,05 & 6,60 & 32 & 7,077 & 7,08 & 6,69 & 52 & 7,049 & 7,05 & 6,58 \\
\hline 13 & 7,073 & 7,04 & 6,59 & 33 & 7,075 & 7,06 & 6,69 & 53 & 7,046 & 7,06 & 6,58 \\
\hline 14 & 7,068 & 7,03 & 6,56 & 34 & 7,071 & 7,06 & 6,68 & 54 & 7,045 & 7,08 & 6,60 \\
\hline 15 & 7,062 & 7,04 & 6,59 & 35 & 7,067 & 7,06 & 6,68 & 55 & 7,044 & 7,09 & 6,59 \\
\hline 16 & 7,058 & 7,04 & 6,62 & 36 & 7,065 & 7,06 & 6,66 & 56 & 7,043 & 7,07 & 6,61 \\
\hline 17 & 7,056 & 7,04 & 6,64 & 37 & 7,064 & 7,06 & 6,65 & 57 & 7,045 & 7,06 & 6,61 \\
\hline 18 & 7,052 & 7,04 & 6,66 & 38 & 7,062 & 7,06 & 6,65 & 58 & 7,050 & 7,04 & 6,61 \\
\hline 19 & 7,052 & 7,04 & 6,67 & 39 & 7,057 & 7,06 & 6,65 & 59 & 7,053 & 7,04 & 6,62 \\
\hline 20 & 7,053 & 7,04 & 6,70 & 40 & 7,054 & 7,08 & 6,64 & 60 & 7,053 & 7,04 & 6,64 \\
\hline : & : & : & : & : & : & : & : & : & : & : & : \\
\hline : & : & : & : & : & : & : & : & : & : & : & : \\
\hline : & : & : & : & : & : & : & : & : & : & : & : \\
\hline 1603 & 7,096 & 7,10 & 6,66 & 1631 & 7,099 & 7,08 & 6,77 & 1659 & 7,083 & 7,11 & 6,74 \\
\hline 1604 & 7,095 & 7,11 & 6,65 & 1632 & 7,097 & 7,07 & 6,74 & 1660 & 7,083 & 7,11 & 6,73 \\
\hline 1605 & 7,097 & 7,12 & 6,65 & 1633 & 7,094 & 7,08 & 6,72 & 1661 & 7,083 & 7,11 & 6,72 \\
\hline 1606 & 7,101 & 7,12 & 6,65 & 1634 & 7,090 & 7,09 & 6,70 & 1662 & 7,085 & 7,10 & 6,71 \\
\hline 1607 & 7,102 & 7,12 & 6,65 & 1635 & 7,088 & 7,08 & 6,68 & 1663 & 7,088 & 7,10 & 6,72 \\
\hline 1608 & 7,102 & 7,11 & 6,67 & 1636 & 7,088 & 7,07 & 6,67 & 1664 & 7,092 & 7,11 & 6,73 \\
\hline 1609 & 7,102 & 7,11 & 6,67 & 1637 & 7,090 & 7,07 & 6,69 & 1665 & 7,092 & 7,11 & 6,72 \\
\hline 1610 & 7,101 & 7,12 & 6,65 & 1638 & 7,089 & 7,08 & 6,69 & 1666 & 7,09 & 7,10 & 6,72 \\
\hline 1611 & 7,099 & 7,12 & 6,64 & 1639 & 7,088 & 7,09 & 6,69 & 1667 & 7,092 & 7,10 & 6,74 \\
\hline 1612 & 7,096 & 7,11 & 6,63 & 1640 & 7,087 & 7,09 & 6,72 & 1668 & 7,096 & 7,10 & 6,75 \\
\hline 1613 & 7,093 & 7,09 & 6,62 & 1641 & 7,087 & 7,10 & 6,74 & 1669 & 7,098 & 7,09 & 6,73 \\
\hline 1614 & 7,091 & 7,09 & 6,62 & 1642 & 7,088 & 7,11 & 6,75 & 1670 & 7,099 & 7,10 & 6,71 \\
\hline 1615 & 7,09 & 7,10 & 6,62 & 1643 & 7,087 & 7,12 & 6,75 & 1671 & 7,096 & 7,09 & 6,69 \\
\hline 1616 & 7,093 & 7,11 & 6,63 & 1644 & 7,088 & 7,13 & 6,77 & 1672 & 7,093 & 7,09 & 6,68 \\
\hline 1617 & 7,095 & 7,10 & 6,62 & 1645 & 7,093 & 7,12 & 6,75 & 1673 & 7,09 & 7,09 & 6,67 \\
\hline 1618 & 7,096 & 7,09 & 6,63 & 1646 & 7,102 & 7,12 & 6,77 & 1674 & 7,087 & 7,09 & 6,68 \\
\hline 1619 & 7,099 & 7,10 & 6,67 & 1647 & 7,113 & 7,12 & 6,76 & 1675 & 7,088 & 7,09 & 6,69 \\
\hline 1620 & 7,099 & 7,12 & 6,69 & 1648 & 7,116 & 7,12 & 6,74 & 1676 & 7,089 & 7,11 & 6,71 \\
\hline 1621 & 7,101 & 7,13 & 6,71 & 1649 & 7,119 & 7,11 & 6,72 & 1677 & 7,091 & 7,13 & 6,72 \\
\hline 1622 & 7,103 & 7,12 & 6,71 & 1650 & 7,108 & 7,11 & 6,72 & 1678 & 7,094 & 7,14 & 6,71 \\
\hline 1623 & 7,105 & 7,10 & 6,72 & 1651 & 7,099 & 7,10 & 6,73 & 1679 & 7,097 & 7,12 & 6,68 \\
\hline 1624 & 7,104 & 7,10 & 6,71 & 1652 & 7,097 & 7,09 & 6,73 & 1680 & 7,101 & 7,11 & 6,69 \\
\hline 1625 & 7,104 & 7,11 & 6,71 & 1653 & 7,096 & 7,11 & 6,75 & 1681 & 7,107 & 7,11 & 6,70 \\
\hline 1626 & 7,101 & 7,12 & 6,71 & 1654 & 7,095 & 7,10 & 6,75 & 1682 & 7,107 & 7,09 & 6,70 \\
\hline 1627 & 7,101 & 7,12 & 6,74 & 1655 & 7,093 & 7,08 & 6,75 & 1683 & 7,106 & 7,08 & 6,71 \\
\hline 1628 & 7,101 & 7,11 & 6,75 & 1656 & 7,094 & 7,08 & 6,75 & 1684 & 7,106 & 7,08 & 6,71 \\
\hline 1629 & 7,100 & 7,10 & 6,78 & 1657 & 7,090 & 7,08 & 6,75 & 1685 & 7,104 & 7,10 & 6,68 \\
\hline 1630 & 7,099 & 7,08 & 6,79 & 1658 & 7,086 & 7,10 & 6,75 & 1686 & 7,101 & 7,10 & 6,68 \\
\hline
\end{tabular}


Tabela 34 - Dados obtidos com o rotor da bomba hidráulica girando na frequência de $30 \mathrm{~Hz}$

\begin{tabular}{|c|c|c|c|c|c|c|c|c|c|c|c|}
\hline \multicolumn{12}{|c|}{$\begin{array}{c}\text { Dados obtidos na frequência de } 30 \mathrm{~Hz} \text { : } \\
\text { Tabela com todos valores medidos (Inclui possíveis outliers) }\end{array}$} \\
\hline Medições & $\begin{array}{l}\text { Qpadrão } \\
\mathrm{m}^{3} / \mathrm{h}\end{array}$ & $\begin{array}{l}\text { QIFM } \\
\mathrm{m}^{3} / \mathrm{h}\end{array}$ & $\begin{array}{l}\text { Qvectus } \\
\mathrm{m}^{3} / \mathrm{h}\end{array}$ & Medições & $\begin{array}{c}\text { QPadrão } \\
\mathrm{m}^{3} / \mathrm{h}\end{array}$ & $\begin{array}{l}\text { QIFM } \\
\mathrm{m}^{3} / \mathrm{h}\end{array}$ & $\begin{array}{c}\text { QVECTUS } \\
\mathrm{m}^{3} / \mathrm{h}\end{array}$ & Medições & $\begin{array}{c}\text { Qpadrão } \\
\mathrm{m}^{3} / \mathrm{h}\end{array}$ & $\begin{array}{l}\text { QIFM } \\
\mathrm{m}^{3} / \mathrm{h}\end{array}$ & $\begin{array}{c}\text { QVECTUS } \\
\mathrm{m}^{3} / \mathrm{h}\end{array}$ \\
\hline 1 & 5,577 & 5,61 & 6,31 & 21 & 5,578 & 5,60 & 6,29 & 41 & 5,580 & 5,60 & 6,31 \\
\hline 2 & 5,577 & 5,61 & 6,30 & 22 & 5,580 & 5,60 & 6,30 & 42 & 5,580 & 5,61 & 6,30 \\
\hline 3 & 5,577 & 5,61 & 6,28 & 23 & 5,582 & 5,61 & 6,29 & 43 & 5,581 & 5,61 & 6,30 \\
\hline 4 & 5,578 & 5,61 & 6,29 & 24 & 5,584 & 5,61 & 6,30 & 44 & 5,583 & 5,61 & 6,29 \\
\hline 5 & 5,579 & 5,61 & 6,30 & 25 & 5,586 & 5,61 & 6,32 & 45 & 5,583 & 5,61 & 6,28 \\
\hline 6 & 5,579 & 5,60 & 6,31 & 26 & 5,588 & 5,60 & 6,33 & 46 & 5,582 & 5,61 & 6,29 \\
\hline 7 & 5,579 & 5,61 & 6,31 & 27 & 5,588 & 5,60 & 6,33 & 47 & 5,582 & 5,61 & 6,30 \\
\hline 8 & 5,579 & 5,61 & 6,31 & 28 & 5,586 & 5,60 & 6,31 & 48 & 5,582 & 5,61 & 6,30 \\
\hline 9 & 5,581 & 5,61 & 6,31 & 29 & 5,584 & 5,60 & 6,32 & 49 & 5,584 & 5,61 & 6,31 \\
\hline 10 & 5,583 & 5,61 & 6,31 & 30 & 5,583 & 5,60 & 6,32 & 50 & 5,586 & 5,61 & 6,31 \\
\hline 11 & 5,584 & 5,61 & 6,30 & 31 & 5,582 & 5,61 & 6,31 & 51 & 5,587 & 5,61 & 6,31 \\
\hline 12 & 5,583 & 5,61 & 6,30 & 32 & 5,582 & 5,62 & 6,31 & 52 & 5,588 & 5,61 & 6,30 \\
\hline 13 & 5,582 & 5,61 & 6,30 & 33 & 5,581 & 5,61 & 6,32 & 53 & 5,590 & 5,60 & 6,31 \\
\hline 14 & 5,582 & 5,61 & 6,29 & 34 & 5,579 & 5,61 & 6,32 & 54 & 5,590 & 5,61 & 6,31 \\
\hline 15 & 5,583 & 5,61 & 6,29 & 35 & 5,579 & 5,60 & 6,33 & 55 & 5,588 & 5,61 & 6,33 \\
\hline 16 & 5,582 & 5,61 & 6,29 & 36 & 5,581 & 5,60 & 6,32 & 56 & 5,588 & 5,61 & 6,35 \\
\hline 17 & 5,581 & 5,61 & 6,30 & 37 & 5,582 & 5,61 & 6,33 & 57 & 5,588 & 5,61 & 6,35 \\
\hline 18 & 5,579 & 5,61 & 6,30 & 38 & 5,582 & 5,61 & 6,32 & 58 & 5,588 & 5,61 & 6,35 \\
\hline 19 & 5,577 & 5,61 & 6,29 & 39 & 5,582 & 5,61 & 6,32 & 59 & 5,588 & 5,61 & 6,35 \\
\hline 20 & 5,577 & 5,61 & 6,28 & 40 & 5,581 & 5,61 & 6,32 & 60 & 5,588 & 5,62 & 6,35 \\
\hline : & : & : & : & : & : & : & : & : & : & : & : \\
\hline : & : & : & : & : & : & : & : & : & : & : & : \\
\hline : & : & : & : & : & : & : & : & : & : & : & : \\
\hline 1984 & 5,596 & 5,62 & 6,38 & 2012 & 5,607 & 5,62 & 6,34 & 2040 & 5,613 & 5,62 & 6,35 \\
\hline 1985 & 5,598 & 5,61 & 6,40 & 2013 & 5,606 & 5,62 & 6,33 & 2041 & 5,611 & 5,63 & 6,35 \\
\hline 1986 & 5,598 & 5,61 & 6,40 & 2014 & 5,607 & 5,62 & 6,34 & 2042 & 5,610 & 5,62 & 6,35 \\
\hline 1987 & 5,598 & 5,61 & 6,39 & 2015 & 5,608 & 5,63 & 6,33 & 2043 & 5,611 & 5,62 & 6,35 \\
\hline 1988 & 5,599 & 5,62 & 6,38 & 2016 & 5,608 & 5,63 & 6,33 & 2044 & 5,615 & 5,62 & 6,34 \\
\hline 1989 & 5,601 & 5,62 & 6,37 & 2017 & 5,609 & 5,62 & 6,34 & 2045 & 5,616 & 5,62 & 6,33 \\
\hline 1990 & 5,601 & 5,62 & 6,37 & 2018 & 5,611 & 5,62 & 6,34 & 2046 & 5,613 & 5,63 & 6,33 \\
\hline 1991 & 5,600 & 5,62 & 6,35 & 2019 & 5,611 & 5,62 & 6,35 & 2047 & 5,609 & 5,63 & 6,32 \\
\hline 1992 & 5,599 & 5,62 & 6,34 & 2020 & 5,612 & 5,62 & 6,33 & 2048 & 5,607 & 5,63 & 6,31 \\
\hline 1993 & 5,599 & 5,62 & 6,35 & 2021 & 5,612 & 5,62 & 6,32 & 2049 & 5,603 & 5,62 & 6,32 \\
\hline 1994 & 5,598 & 5,62 & 6,35 & 2022 & 5,612 & 5,62 & 6,32 & 2050 & 5,601 & 5,62 & 6,32 \\
\hline 1995 & 5,597 & 5,62 & 6,36 & 2023 & 5,613 & 5,62 & 6,32 & 2051 & 5,600 & 5,61 & 6,32 \\
\hline 1996 & 5,598 & 5,62 & 6,36 & 2024 & 5,612 & 5,62 & 6,329 & 2052 & 5,601 & 5,61 & 6,30 \\
\hline 1997 & 5,597 & 5,63 & 6,36 & 2025 & 5,611 & 5,62 & 6,325 & 2053 & 5,602 & 5,62 & 6,29 \\
\hline 1998 & 5,598 & 5,63 & 6,36 & 2026 & 5,609 & 5,62 & 6,318 & 2054 & 5,603 & 5,62 & 6,28 \\
\hline 1999 & 5,601 & 5,62 & 6,36 & 2027 & 5,609 & 5,62 & 6,318 & 2055 & 5,604 & 5,62 & 6,27 \\
\hline 2000 & 5,603 & 5,62 & 6,35 & 2028 & 5,609 & 5,62 & 6,318 & 2056 & 5,606 & 5,63 & 6,28 \\
\hline 2001 & 5,605 & 5,62 & 6,34 & 2029 & 5,610 & 5,63 & 6,317 & 2057 & 5,606 & 5,64 & 6,29 \\
\hline 2002 & 5,607 & 5,62 & 6,34 & 2030 & 5,611 & 5,62 & 6,325 & 2058 & 5,607 & 5,63 & 6,30 \\
\hline 2003 & 5,606 & 5,62 & 6,33 & 2031 & 5,613 & 5,63 & 6,324 & 2059 & 5,609 & 5,62 & 6,31 \\
\hline 2004 & 5,605 & 5,62 & 6,33 & 2032 & 5,615 & 5,63 & 6,336 & 2060 & 5,609 & 5,61 & 6,31 \\
\hline 2005 & 5,605 & 5,62 & 6,35 & 2033 & 5,615 & 5,63 & 6,35 & 2061 & 5,607 & 5,62 & 6,33 \\
\hline 2006 & 5,605 & 5,62 & 6,35 & 2034 & 5,614 & 5,63 & 6,359 & 2062 & 5,604 & 5,62 & 6,32 \\
\hline 2007 & 5,604 & 5,63 & 6,35 & 2035 & 5,615 & 5,63 & 6,371 & 2063 & 5,604 & 5,62 & 6,33 \\
\hline 2008 & 5,603 & 5,63 & 6,35 & 2036 & 5,615 & 5,63 & 6,379 & 2064 & 5,604 & 5,62 & 6,32 \\
\hline 2009 & 5,605 & 5,63 & 6,34 & 2037 & 5,616 & 5,62 & 6,375 & 2065 & 5,605 & 5,62 & 6,31 \\
\hline 2010 & 5,606 & 5,63 & 6,34 & 2038 & 5,615 & 5,61 & 6,362 & 2066 & 5,607 & 5,63 & 6,33 \\
\hline 2011 & 5,607 & 5,62 & 6,34 & 2039 & 5,615 & 5,62 & 6,358 & 2067 & 5,607 & 5,63 & 6,34 \\
\hline
\end{tabular}




\section{Apêndice D: Calibração do subsistema de medição de pressão}

Neste apêndice são apresentados os dados de calibração dos medidores de pressão, que compõem o subsistema de medição de pressão, instalados no SIREA 3. A caracterização dos instrumentos apresentados neste apêndice está especificada no Capítulo 5.

Os dados apresentados nas tabelas, a seguir, foram obtidos de maneira experimental e seguindo todos as orientações de boas práticas de calibração de instrumentos de medição.

Tabela 35 - Valores de medição de pressão do medidor P1 e manômetro padrão

\begin{tabular}{|c|c|c|c|c|c|c|c|}
\hline \multirow[t]{2}{*}{$\begin{array}{l}\text { № de } \\
\text { pontos }\end{array}$} & \multirow[t]{2}{*}{$\begin{array}{l}\text { Padrão } \\
\left(\mathrm{kgf} / \mathrm{cm}^{2}\right)\end{array}$} & \multicolumn{4}{|c|}{ Transmissor de pressão P1 } & \multirow[t]{2}{*}{$\begin{array}{c}\text { Média do } \\
\text { transdutor } \\
\text { P1 } \\
\text { (bar) }\end{array}$} & \multirow[t]{2}{*}{$\begin{array}{c}\text { Desv. Pad. do } \\
\text { transdutor P1 } \\
\text { (bar) }\end{array}$} \\
\hline & & Carre & lento & Desca & amento & & \\
\hline 1 & 0,00 & 0,00 & 0,00 & 0,00 & 0,00 & 0,00 & 0,000 \\
\hline 2 & 1,00 & 1,00 & 1,00 & 0,99 & 1,00 & 1,00 & 0,004 \\
\hline 3 & 2,00 & 2,00 & 2,00 & 2,00 & 1,96 & 1,99 & 0,018 \\
\hline 4 & 3,00 & 3,00 & 3,00 & 3,00 & 3,00 & 3,00 & 0,000 \\
\hline 5 & 4,00 & 3,99 & 4,00 & 4,00 & 4,00 & 4,00 & 0,004 \\
\hline 6 & 5,00 & 5,00 & 5,01 & 5,00 & 5,00 & 5,00 & 0,004 \\
\hline 7 & 6,00 & 6,00 & 5,99 & 6,00 & 5,99 & 6,00 & 0,005 \\
\hline 8 & 7,00 & 7,01 & 7,00 & 7,00 & 6,99 & 7,00 & 0,007 \\
\hline 9 & 8,00 & 7,99 & 7,98 & 8,01 & 8,01 & 8,00 & 0,013 \\
\hline 10 & 9,00 & 8,97 & 8,99 & 9,00 & 9,00 & 8,99 & 0,013 \\
\hline 11 & 10,00 & 9,99 & 10,01 & 9,99 & 10,01 & 10,00 & 0,010 \\
\hline
\end{tabular}

Tabela 36 - Valores de medição de pressão do medidor P2 e manômetro padrão

\begin{tabular}{|c|c|c|c|c|c|c|c|}
\hline \multirow[t]{2}{*}{$\begin{array}{c}\text { № de } \\
\text { pontos }\end{array}$} & \multirow[t]{2}{*}{$\begin{array}{l}\text { Padrão } \\
\left(\mathrm{kgf} / \mathrm{cm}^{2}\right) \\
\end{array}$} & \multicolumn{4}{|c|}{ Transmissor de pressão P2 } & \multirow[t]{2}{*}{$\begin{array}{c}\text { Média do } \\
\text { transdutor } \\
\text { P2 } \\
\text { (bar) }\end{array}$} & \multirow[t]{2}{*}{$\begin{array}{c}\text { Desv. Pad. do } \\
\text { transdutor P2 } \\
\text { (bar) }\end{array}$} \\
\hline & & Carre & iento & Desca & amento & & \\
\hline 1 & 0,00 & 0,00 & 0,00 & 0,00 & 0,00 & 0,00 & 0,000 \\
\hline 2 & 1,00 & 1,00 & 1,00 & 0,99 & 1,00 & 1,00 & 0,004 \\
\hline 3 & 2,00 & 2,00 & 2,00 & 2,00 & 2,00 & 2,00 & 0,000 \\
\hline 4 & 3,00 & 3,00 & 3,00 & 3,00 & 3,00 & 3,00 & 0,000 \\
\hline 5 & 4,00 & 3,99 & 4,00 & 4,00 & 4,00 & 4,00 & 0,004 \\
\hline 6 & 5,00 & 5,00 & 5,01 & 5,00 & 5,00 & 5,00 & 0,004 \\
\hline 7 & 6,00 & 6,00 & 5,99 & 6,00 & 5,99 & 6,00 & 0,005 \\
\hline 8 & 7,00 & 7,00 & 7,00 & 7,00 & 6,99 & 7,00 & 0,004 \\
\hline 9 & 8,00 & 8,01 & 8,01 & 8,01 & 8,01 & 8,01 & 0,004 \\
\hline 10 & 9,00 & 8,99 & 8,99 & 9,00 & 9,00 & 9,00 & 0,005 \\
\hline 11 & 10,00 & 9,99 & 10,00 & 9,99 & 10,00 & 10,00 & 0,005 \\
\hline
\end{tabular}

Tabela 37 - Valores de medição de pressão do medidor P3 e manômetro padrão

\begin{tabular}{|c|c|c|c|c|c|c|c|}
\hline \multirow[t]{2}{*}{$\begin{array}{l}\text { № de } \\
\text { pontos }\end{array}$} & \multirow[t]{2}{*}{$\begin{array}{l}\text { Padrão } \\
\left(\mathrm{kgf} / \mathrm{cm}^{2}\right) \\
\end{array}$} & \multicolumn{4}{|c|}{ Transmissor de pressão P3 } & \multirow[t]{2}{*}{$\begin{array}{c}\text { Média do } \\
\text { transdutor } \\
\text { P3 } \\
\text { (bar) } \\
\end{array}$} & \multirow[t]{2}{*}{$\begin{array}{c}\text { Desv. Pad. do } \\
\text { transdutor P3 } \\
\text { (bar) }\end{array}$} \\
\hline & & Carre & nento & Descal & amento & & \\
\hline 1 & 0,00 & 0,00 & 0,00 & 0,00 & 0,00 & 0,00 & 0,000 \\
\hline 2 & 1,00 & 1,00 & 1,00 & 0,99 & 1,00 & 1,00 & 0,004 \\
\hline 3 & 2,00 & 2,00 & 2,00 & 2,00 & 1,98 & 2,00 & 0,009 \\
\hline 4 & 3,00 & 3,00 & 3,00 & 3,00 & 3,00 & 3,00 & 0,000 \\
\hline 5 & 4,00 & 3,99 & 3,99 & 4,00 & 4,00 & 4,00 & 0,005 \\
\hline 6 & 5,00 & 5,00 & 5,01 & 5,00 & 5,00 & 5,00 & 0,004 \\
\hline 7 & 6,00 & 6,00 & 5,99 & 6,00 & 5,99 & 6,00 & 0,005 \\
\hline 8 & 7,00 & 7,00 & 7,00 & 7,00 & 6,99 & 7,00 & 0,004 \\
\hline 9 & 8,00 & 8,01 & 7,98 & 8,01 & 8,01 & 8,00 & 0,013 \\
\hline 10 & 9,00 & 8,99 & 8,99 & 9,00 & 9,00 & 9,00 & 0,005 \\
\hline 11 & 10,00 & 9,99 & 10,00 & 9,99 & 10,00 & 10,00 & 0,005 \\
\hline
\end{tabular}


Tabela 38 - Valores de medição de pressão do medidor diferencial e manômetro padrão

\begin{tabular}{|c|c|c|c|c|c|c|c|}
\hline \multirow{3}{*}{$\begin{array}{l}\text { № de } \\
\text { pontos }\end{array}$} & \multirow{3}{*}{$\begin{array}{l}\text { Medidor } \\
\text { de } \\
\text { pressão } \\
\text { diferencial } \\
\text { (bar) }\end{array}$} & \multicolumn{4}{|c|}{ Manômetro padrão } & \multirow{3}{*}{$\begin{array}{c}\text { Média do } \\
\text { manômetro } \\
\text { padrão } \\
\left(\mathrm{kgf} / \mathrm{cm}^{2}\right)\end{array}$} & \multirow{3}{*}{$\begin{array}{c}\text { Desv. Pad. do } \\
\text { manômetro } \\
\text { padrão } \\
\left(\mathrm{kgf} / \mathrm{cm}^{2}\right)\end{array}$} \\
\hline & & \multicolumn{4}{|c|}{$\left(\mathrm{kgf} / \mathrm{cm}^{2}\right)$} & & \\
\hline & & Carre & nento & Desca & amento & & \\
\hline 1 & 0,00 & 0,00 & 0,00 & 0,00 & 0,00 & 0,00 & 0,000 \\
\hline 2 & 0,92 & 0,89 & 0,92 & 0,91 & 0,90 & 0,91 & 0,013 \\
\hline 3 & 1,08 & 1,04 & 1,06 & 1,06 & 1,08 & 1,06 & 0,017 \\
\hline 4 & 1,26 & 1,19 & 1,24 & 1,23 & 1,28 & 1,24 & 0,034 \\
\hline 5 & 1,45 & 1,40 & 1,44 & 1,43 & 1,45 & 1,43 & 0,021 \\
\hline 6 & 1,66 & 1,60 & 1,70 & 1,66 & 1,64 & 1,65 & 0,036 \\
\hline 7 & 1,88 & 1,87 & 1,87 & 1,87 & 1,90 & 1,88 & 0,013 \\
\hline 8 & 2,13 & 2,10 & 2,17 & 2,12 & 2,12 & 2,13 & 0,026 \\
\hline 9 & 2,38 & 2,38 & 2,34 & 2,42 & 2,40 & 2,39 & 0,030 \\
\hline 10 & 2,66 & 2,62 & 2,71 & 2,67 & 2,66 & 2,67 & 0,032 \\
\hline 11 & 2,94 & 2,84 & 2,90 & 2,98 & 2,97 & 2,92 & 0,057 \\
\hline 12 & 3,16 & 3,20 & 3,13 & 3,12 & 3,19 & 3,16 & 0,035 \\
\hline
\end{tabular}

Tabela 39 - Incertezas associadas ao transdutor de pressão P1

\begin{tabular}{c|ccccccc}
\hline \multirow{3}{*}{$\begin{array}{c}\text { № de } \\
\text { pontos }\end{array}$} & $\begin{array}{c}\text { Resolução } \\
\text { Uinst }\end{array}$ & $\begin{array}{c}\text { Repetibilidade } \\
u_{r}\end{array}$ & $\begin{array}{c}\text { Padrão } \\
u_{\text {pad }}\end{array}$ & $\begin{array}{c}\text { Ajuste pelo } \\
\text { polinômio } \\
u_{s}\end{array}$ & $\begin{array}{c}\text { Combinada } \\
u_{c}\end{array}$ & $\begin{array}{c}\text { Fator de } \\
\text { abrangência } \\
k\end{array}$ & $\begin{array}{c}\text { Expandida } \\
U_{\text {exp }}\end{array}$ \\
\cline { 2 - 8 } & $($ bar) & $($ bar) & $($ bar $)$ & $($ bar) & $($ bar) & $(95,0 \%)$ & $($ bar) \\
\hline 1 & 0,002 & 0,000 & 0,005 & 0,003 & 0,006 & 1,96 & 0,01 \\
2 & 0,002 & 0,003 & 0,005 & 0,002 & 0,007 & 1,98 & 0,01 \\
3 & 0,002 & 0,010 & 0,005 & 0,002 & 0,012 & 2,57 & 0,03 \\
4 & 0,002 & 0,000 & 0,005 & 0,002 & 0,006 & 1,96 & 0,01 \\
5 & 0,002 & 0,003 & 0,005 & 0,002 & 0,006 & 1,98 & 0,01 \\
6 & 0,002 & 0,003 & 0,005 & 0,002 & 0,006 & 1,98 & 0,01 \\
7 & 0,002 & 0,003 & 0,005 & 0,002 & 0,006 & 2,00 & 0,01 \\
8 & 0,002 & 0,004 & 0,005 & 0,002 & 0,007 & 2,06 & 0,01 \\
9 & 0,002 & 0,008 & 0,005 & 0,002 & 0,010 & 2,36 & 0,02 \\
10 & 0,002 & 0,007 & 0,005 & 0,002 & 0,009 & 2,31 & 0,02 \\
11 & 0,002 & 0,006 & 0,005 & 0,003 & 0,009 & 2,16 & 0,02 \\
\hline
\end{tabular}

Tabela 40 - Incertezas associados ao transdutor de pressão P2

\begin{tabular}{c|ccccccc}
\hline \multirow{3}{*}{$\begin{array}{c}\text { No de } \\
\text { pontos }\end{array}$} & $\begin{array}{c}\text { Resolução } \\
u_{\text {inst }}\end{array}$ & $\begin{array}{c}\text { Repetibilidade } \\
u_{r}\end{array}$ & $\begin{array}{c}\text { Padrão } \\
u_{\text {pad }}\end{array}$ & $\begin{array}{c}\text { Ajuste pelo } \\
\text { polinômio } \\
u_{s}\end{array}$ & $\begin{array}{c}\text { Combinada } \\
u_{c}\end{array}$ & $\begin{array}{c}\text { Fator de } \\
\text { abrangência } \\
k\end{array}$ & $\begin{array}{c}\text { Expandida } \\
U_{\text {exp }}\end{array}$ \\
\cline { 2 - 8 } & bar & bar & bar & bar & bar & $95,0 \%$ & bar \\
\hline 1 & 0,002 & 0,000 & 0,005 & 0,002 & 0,006 & 1,96 & 0,01 \\
2 & 0,002 & 0,003 & 0,005 & 0,002 & 0,006 & 1,98 & 0,01 \\
3 & 0,002 & 0,005 & 0,005 & 0,001 & 0,008 & 2,57 & 0,02 \\
4 & 0,002 & 0,000 & 0,005 & 0,001 & 0,006 & 1,96 & 0,01 \\
5 & 0,002 & 0,003 & 0,005 & 0,001 & 0,006 & 1,98 & 0,01 \\
6 & 0,002 & 0,003 & 0,005 & 0,001 & 0,006 & 1,98 & 0,01 \\
7 & 0,002 & 0,003 & 0,005 & 0,001 & 0,006 & 2,00 & 0,01 \\
8 & 0,002 & 0,003 & 0,005 & 0,001 & 0,006 & 2,06 & 0,01 \\
9 & 0,002 & 0,008 & 0,005 & 0,001 & 0,009 & 2,36 & 0,02 \\
10 & 0,002 & 0,003 & 0,005 & 0,002 & 0,006 & 2,31 & 0,01 \\
11 & 0,002 & 0,003 & 0,005 & 0,002 & 0,007 & 2,16 & 0,01 \\
\hline
\end{tabular}

Tabela 41 - Incertezas associados ao transdutor de pressão P3

\begin{tabular}{c|ccccccc}
\hline \multirow{2}{*}{$\begin{array}{c}\text { No de } \\
\text { pontos }\end{array}$} & $\begin{array}{c}\text { Resolução } \\
\text { Uinst }\end{array}$ & $\begin{array}{c}\text { Repetibilidade } \\
u_{r}\end{array}$ & $\begin{array}{c}\text { Padrão } \\
u_{\text {pad }}\end{array}$ & $\begin{array}{c}\text { Ajuste pelo } \\
\text { polinômio } \\
u_{s}\end{array}$ & $\begin{array}{c}\text { Combinada } \\
u_{c}\end{array}$ & $\begin{array}{c}\text { Fator de } \\
\text { abrangência } \\
k\end{array}$ & $\begin{array}{c}\text { Expandida } \\
U_{\exp }\end{array}$ \\
\cline { 2 - 8 } & bar & bar & bar & bar & bar & $95,0 \%$ & bar \\
\hline 1 & 0,002 & 0,000 & 0,005 & 0,002 & 0,006 & 1,96 & 0,01 \\
2 & 0,002 & 0,003 & 0,005 & 0,001 & 0,006 & 1,98 & 0,01 \\
3 & 0,002 & 0,000 & 0,005 & 0,001 & 0,006 & 1,96 & 0,01 \\
4 & 0,002 & 0,000 & 0,005 & 0,001 & 0,006 & 1,96 & 0,01 \\
5 & 0,002 & 0,003 & 0,005 & 0,001 & 0,006 & 1,98 & 0,01 \\
6 & 0,002 & 0,003 & 0,005 & 0,001 & 0,006 & 1,98 & 0,01 \\
7 & 0,002 & 0,003 & 0,005 & 0,001 & 0,006 & 2,00 & 0,01 \\
8 & 0,002 & 0,003 & 0,005 & 0,001 & 0,006 & 1,98 & 0,01 \\
9 & 0,002 & 0,000 & 0,005 & 0,001 & 0,006 & 1,96 & 0,01 \\
10 & 0,002 & 0,003 & 0,005 & 0,001 & 0,006 & 2,00 & 0,01 \\
11 & 0,002 & 0,003 & 0,005 & 0,002 & 0,006 & 2,00 & 0,01 \\
\hline
\end{tabular}


Tabela 42 - Incertezas associados ao medidor de pressão diferencial

\begin{tabular}{c|ccccccc}
\hline \multirow{2}{*}{$\begin{array}{c}\text { No de } \\
\text { pontos }\end{array}$} & $\begin{array}{c}\text { Resolução } \\
\text { Uinst }\end{array}$ & $\begin{array}{c}\text { Repetibilidade } \\
u_{r}\end{array}$ & $\begin{array}{c}\text { Padrão } \\
u_{\text {pad }}\end{array}$ & $\begin{array}{c}\text { Ajuste pelo } \\
\text { polinômio } \\
u_{s}\end{array}$ & $\begin{array}{c}\text { Combinada } \\
u_{c}\end{array}$ & $\begin{array}{c}\text { Fator de } \\
\text { abrangência } \\
k\end{array}$ & $\begin{array}{c}\text { Expandida } \\
U_{\text {exp }}\end{array}$ \\
\cline { 2 - 8 } & bar & bar & bar & bar & bar & $95,0 \%$ & bar \\
\hline 1 & 0,003 & 0,000 & 0,005 & 0,012 & 0,013 & 1,99 & 0,03 \\
2 & 0,003 & 0,006 & 0,005 & 0,007 & 0,011 & 2,06 & 0,02 \\
3 & 0,003 & 0,008 & 0,005 & 0,007 & 0,012 & 2,16 & 0,03 \\
4 & 0,003 & 0,018 & 0,005 & 0,006 & 0,020 & 2,78 & 0,06 \\
5 & 0,003 & 0,011 & 0,005 & 0,005 & 0,013 & 2,36 & 0,03 \\
6 & 0,003 & 0,021 & 0,005 & 0,005 & 0,022 & 3,18 & 0,07 \\
7 & 0,003 & 0,007 & 0,005 & 0,005 & 0,011 & 2,20 & 0,02 \\
8 & 0,003 & 0,015 & 0,005 & 0,005 & 0,017 & 2,78 & 0,05 \\
9 & 0,003 & 0,017 & 0,005 & 0,006 & 0,019 & 2,78 & 0,05 \\
10 & 0,003 & 0,018 & 0,005 & 0,006 & 0,020 & 2,78 & 0,06 \\
11 & 0,003 & 0,033 & 0,005 & 0,008 & 0,034 & 3,18 & 0,11 \\
12 & 0,003 & 0,023 & 0,005 & 0,009 & 0,025 & 2,78 & 0,07 \\
\hline
\end{tabular}

Tabela 43 - Incertezas associadas aos polinômios de ajuste

\begin{tabular}{|c|c|c|c|c|c|}
\hline \multicolumn{2}{|c|}{$\begin{array}{c}\text { Polinômio de ajuste } \\
\text { de grau } 1\end{array}$} & \multicolumn{2}{|c|}{$\begin{array}{c}\text { Polinômio de ajuste } \\
\text { de grau } 2 \\
\end{array}$} & \multicolumn{2}{|c|}{$\begin{array}{c}\text { Polinômio de ajuste } \\
\text { de grau } 3\end{array}$} \\
\hline $\mathrm{uTS}_{1 \text { ajust }}$ & uTS $_{\text {2ajust }}$ & uTS $_{\text {1ajust }}$ & uTS $_{\text {2ajust }}$ & uTS $_{\text {1ajust }}$ & $\mathrm{uTS}_{\text {2ajust }}$ \\
\hline${ }^{\circ} \mathrm{C}$ & ${ }^{\circ} \mathrm{C}$ & ${ }^{\circ} \mathrm{C}$ & ${ }^{\circ} \mathrm{C}$ & ${ }^{\circ} \mathrm{C}$ & ${ }^{\circ} \mathrm{C}$ \\
\hline 0,0554 & 0,0921 & 0,0576 & 0,1385 & 0,0607 & 0,1015 \\
\hline
\end{tabular}

Tabela 44 - Erros sistemáticos associados aos valores corrigidos de $\mathrm{TS}_{1}$ e TS 2

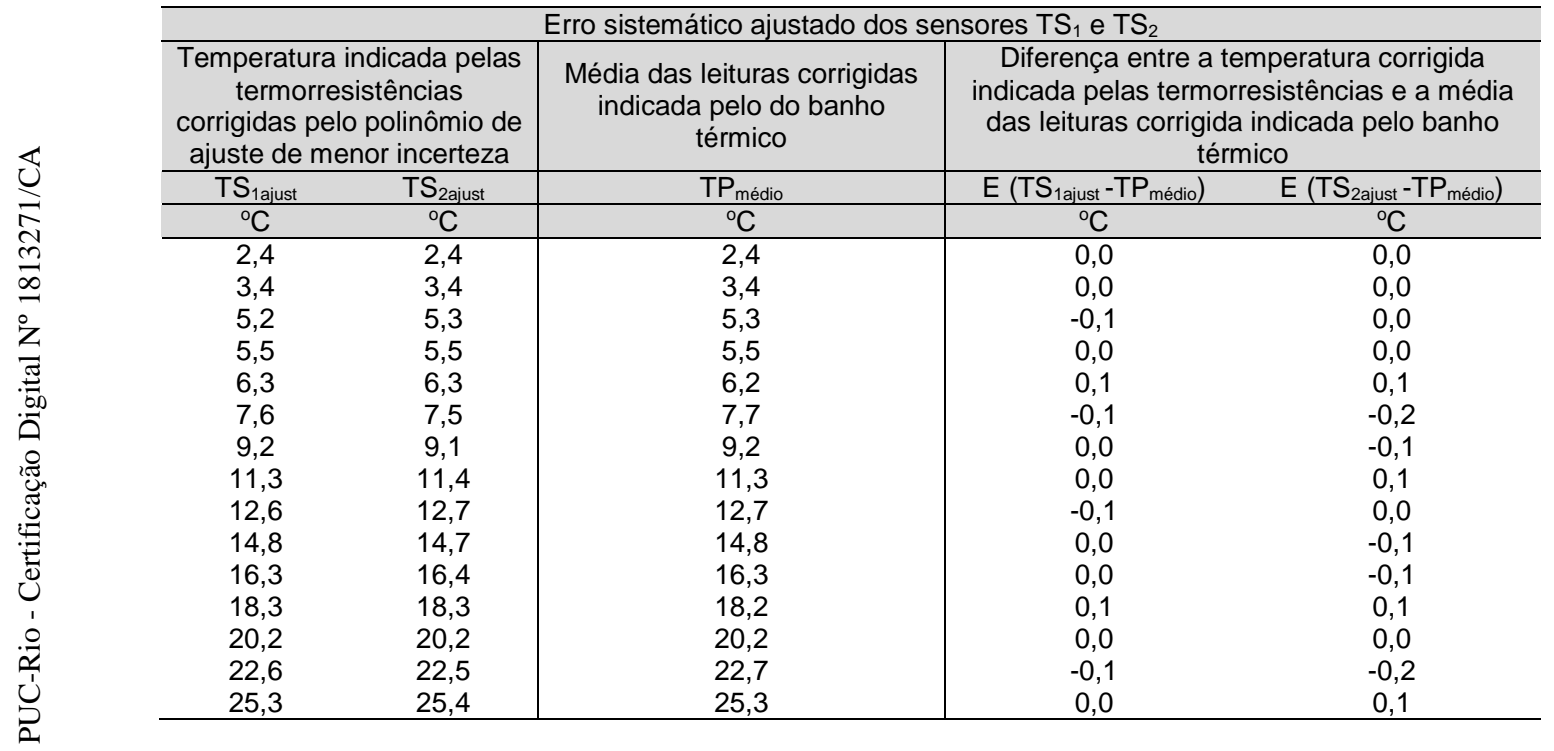




\section{Apêndice E: Calibração do subsistema de temperatura}

Nesse apêndice são apresentados o procedimento e os dados de calibração das termorresistências Pt 100, que compõem o subsistema de temperatura, instaladas no SIREA 3. A caracterização dos instrumentos apresentados neste apêndice está especificada no Capítulo 5.

Os dados apresentados nas tabelas, a seguir, foram obtidos de maneira experimental e seguindo todos as orientações de boas práticas de calibração de instrumentos de medição.

Tabela 45 - Valores de medição indicados pelas termorresistências e pelo padrão

\begin{tabular}{|c|c|c|c|c|c|c|c|}
\hline \multirow{4}{*}{$\begin{array}{l}\text { № de } \\
\text { Pontos }\end{array}$} & \multicolumn{7}{|c|}{ Padrão - Temperatura indicada pelo banho térmico } \\
\hline & \multicolumn{2}{|c|}{$\begin{array}{l}\text { Temperatura indicada } \\
\text { pelas termorresistências }\end{array}$} & \multicolumn{2}{|c|}{$\begin{array}{l}\text { Leituras da } \\
\text { temperatura indicada } \\
\text { pelo banho térmico }\end{array}$} & \multicolumn{2}{|c|}{$\begin{array}{l}\text { Valor da temperatura } \\
\text { corrigida pelo polinômio de } \\
\text { ajuste do banho térmico }\end{array}$} & \multirow{2}{*}{$\begin{array}{l}\text { Valor médio da } \\
\text { temperatura corrigida } \\
\text { indicada pelo banho } \\
\text { térmico } \\
\mathrm{TP}_{\text {médio }}\end{array}$} \\
\hline & $\mathrm{TS}_{1}$ & $\mathrm{TS}_{2}$ & $\mathrm{TP}_{1}$ & $\mathrm{TP}_{1}$ & TP $P_{\text {Corr1 }}$ & $\mathrm{TP}_{\text {Corr2 }}$ & \\
\hline & ${ }^{\circ} \mathrm{C}$ & ${ }^{\circ} \mathrm{C}$ & ${ }^{\circ} \mathrm{C}$ & ${ }^{\circ} \mathrm{C}$ & ${ }^{\circ} \mathrm{C}$ & ${ }^{\circ} \mathrm{C}$ & ${ }^{\circ} \mathrm{C}$ \\
\hline 1 & 2,8 & 2,8 & 2,5 & 2,5 & 2,4 & 2,4 & 2,4 \\
\hline 2 & 3,8 & 3,8 & 3,5 & 3,5 & 3,4 & 3,4 & 3,4 \\
\hline 3 & 5,6 & 5,7 & 5,3 & 5,3 & 5,3 & 5,3 & 5,3 \\
\hline 4 & 5,8 & 5,9 & 5,5 & 5,5 & 5,5 & 5,5 & 5,5 \\
\hline 5 & 6,6 & 6,7 & 6,2 & 6,2 & 6,2 & 6,2 & 6,2 \\
\hline 6 & 7,9 & 7,9 & 7,7 & 7,7 & 7,7 & 7,7 & 7,7 \\
\hline 7 & 9,5 & 9,5 & 9,2 & 9,2 & 9,2 & 9,2 & 9,2 \\
\hline 8 & 11,6 & 11,7 & 11,3 & 11,3 & 11,3 & 11,3 & 11,3 \\
\hline 9 & 12,9 & 13,0 & 12,6 & 12,6 & 12,7 & 12,7 & 12,7 \\
\hline 10 & 15,0 & 15,0 & 14,7 & 14,7 & 14,8 & 14,8 & 14,8 \\
\hline 11 & 16,5 & 16,7 & 16,2 & 16,2 & 16,3 & 16,3 & 16,3 \\
\hline 12 & 18,5 & 18,6 & 18,1 & 18,1 & 18,2 & 18,2 & 18,2 \\
\hline 13 & 20,4 & 20,5 & 20,1 & 20,1 & 20,2 & 20,2 & 20,2 \\
\hline 14 & 22,7 & 22,8 & 22,5 & 22,5 & 22,7 & 22,7 & 22,7 \\
\hline 15 & 25,4 & 25,6 & 25,1 & 25,1 & 25,3 & 25,3 & 25,3 \\
\hline
\end{tabular}

Tabela 46 - Coeficientes dos polinômios de ajuste gerados pela calibração de $\mathrm{TS}_{1}$ e TS 2

\begin{tabular}{|c|c|c|c|}
\hline \multirow{2}{*}{$\begin{array}{l}\text { Grau do } \\
\text { polinômio de ajuste }\end{array}$} & \multirow{2}{*}{$\begin{array}{c}\text { Coeficientes dos } \\
\text { polinômios de ajuste testados }\end{array}$} & \multicolumn{2}{|c|}{$\begin{array}{l}\text { Coeficientes dos polinômios ajuste associados à } \\
\text { calibração das termorresistências }\end{array}$} \\
\hline & & $\mathrm{C} \mathrm{TS}_{1}$ & $\mathrm{C} \mathrm{TS}_{2}$ \\
\hline \multirow{2}{*}{1} & $a$ & 1,0132 & 1,0075 \\
\hline & b & $-0,4249$ & $-0,4355$ \\
\hline \multirow{3}{*}{2} & $a$ & $-4,00 \mathrm{E}-05$ & $-0,0002$ \\
\hline & b & 1,0142 & 1,0117 \\
\hline & c & $-0,4303$ & $-0,4566$ \\
\hline \multirow{4}{*}{3} & $a$ & $3,00 \mathrm{E}-05$ & $-2,00 \mathrm{E}-05$ \\
\hline & b & $-0,0012$ & 0,0006 \\
\hline & c & 1,0276 & 1,0024 \\
\hline & d & $-0,4715$ & $-0,4279$ \\
\hline
\end{tabular}


Tabela 47 - Valores indicados por $\mathrm{TS}_{1}$ e $\mathrm{TS}_{2}$, corrigidos pelos respectivos polinômios de ajuste

\begin{tabular}{|c|c|c|c|c|c|}
\hline \multicolumn{2}{|c|}{ Polinômio de ajuste de grau 1} & \multicolumn{2}{|c|}{ Polinômio de ajuste de grau 2} & \multicolumn{2}{|c|}{ Polinômio de ajuste de grau 3} \\
\hline $\mathrm{TS}_{1 \text { ajust }}$ & TS 2ajust & $\mathrm{TS}_{1 \text { ajust }}$ & $\mathrm{TS}_{\text {2ajust }}$ & TS 1 ajust & TS 2ajust \\
\hline${ }^{\circ} \mathrm{C}$ & ${ }^{\circ} \mathrm{C}$ & ${ }^{\circ} \mathrm{C}$ & ${ }^{\circ} \mathrm{C}$ & ${ }^{\circ} \mathrm{C}$ & ${ }^{\circ} \mathrm{C}$ \\
\hline 2,4 & 2,4 & 2,4 & 2,4 & 2,4 & 2,4 \\
\hline 3,4 & 3,4 & 3,4 & 3,4 & 3,4 & 3,4 \\
\hline 5,2 & 5,3 & 5,2 & 5,3 & 5,3 & 5,3 \\
\hline 5,5 & 5,5 & 5,5 & 5,6 & 5,5 & 5,5 \\
\hline 6,3 & 6,3 & 6,3 & 6,4 & 6,3 & 6,3 \\
\hline 7,6 & 7,5 & 7,6 & 7,6 & 7,6 & 7,5 \\
\hline 9,2 & 9,1 & 9,2 & 9,2 & 9,2 & 9,1 \\
\hline 11,3 & 11,4 & 11,3 & 11,4 & 11,3 & 11,4 \\
\hline 12,6 & 12,7 & 12,6 & 12,7 & 12,6 & 12,7 \\
\hline 14,8 & 14,7 & 14,8 & 14,8 & 14,8 & 14,7 \\
\hline 16,3 & 16,4 & 16,3 & 16,5 & 16,3 & 16,4 \\
\hline 18,3 & 18,3 & 18,3 & 18,4 & 18,3 & 18,3 \\
\hline 20,2 & 20,2 & 20,2 & 20,3 & 20,2 & 20,2 \\
\hline 22,6 & 22,5 & 22,6 & 22,7 & 22,6 & 22,5 \\
\hline 25,3 & 25,4 & 25,3 & 25,5 & 25,3 & 25,3 \\
\hline
\end{tabular}

Tabela 48 - Erro quadrático de TS $_{1 \text { ajust }}$ e TS 2ajust por TP médio

\begin{tabular}{|c|c|c|c|c|c|}
\hline \multicolumn{2}{|c|}{ Polinômio de ajuste de grau 1} & \multicolumn{2}{|c|}{ Polinômio de ajuste de grau 2} & \multicolumn{2}{|c|}{ Polinômio de ajuste de grau 3} \\
\hline $\begin{array}{c}\mathrm{E}^{2} \text { (TS } \text { 1ajust }^{-} \\
\left.\mathrm{TP}_{\text {médio }}\right)\end{array}$ & $\begin{array}{c}\mathrm{E}^{2} \text { (TS } \text { (Tajust }^{-} \\
\mathrm{TP}_{\text {médio }}\end{array}$ & $\begin{array}{c}\mathrm{E}^{2} \text { (TS } \text { ( }_{\text {ajust }}- \\
\mathrm{TP}_{\text {médio }}\end{array}$ & $\begin{array}{c}\mathrm{E}^{2} \text { (TS } \text { (Tajust }^{-} \\
\mathrm{TP}_{\text {médio }}\end{array}$ & $\begin{array}{c}\mathrm{E}^{2} \text { (TS } \text { T }_{\text {ajust }}- \\
\mathrm{TP}_{\text {médio }}\end{array}$ & $\begin{array}{c}\mathrm{E}^{2} \text { (TS } \text { 2ajust }^{-} \\
\mathrm{TP}_{\text {médio }}\end{array}$ \\
\hline${ }^{\circ} \mathrm{C}^{2}$ & ${ }^{\circ} \mathrm{C}^{2}$ & ${ }^{\circ} \mathrm{C}^{2}$ & ${ }^{\circ} \mathrm{C}^{2}$ & ${ }^{\circ} \mathrm{C}^{2}$ & ${ }^{\circ} \mathrm{C}^{2}$ \\
\hline 0,0000 & 0,0004 & 0,0000 & 0,0000 & 0,0001 & 0,0005 \\
\hline 0,0000 & 0,0009 & 0,0000 & 0,0000 & 0,0000 & 0,0011 \\
\hline 0,0000 & 0,0032 & 0,0000 & 0,0097 & 0,0000 & 0,0025 \\
\hline 0,0000 & 0,0030 & 0,0000 & 0,0096 & 0,0000 & 0,0024 \\
\hline 0,0095 & 0,0224 & 0,0094 & 0,0392 & 0,0104 & 0,0208 \\
\hline 0,0117 & 0,0268 & 0,0117 & 0,0117 & 0,0102 & 0,0285 \\
\hline 0,0001 & 0,0053 & 0,0001 & 0,0001 & 0,0000 & 0,0059 \\
\hline 0,0001 & 0,0002 & 0,0001 & 0,0086 & 0,0000 & 0,0002 \\
\hline 0,0001 & 0,0001 & 0,0001 & 0,0087 & 0,0000 & 0,0000 \\
\hline 0,0000 & 0,0106 & 0,0000 & 0,0000 & 0,0000 & 0,0109 \\
\hline 0,0000 & 0,0086 & 0,0000 & 0,0394 & 0,0000 & 0,0080 \\
\hline 0,0103 & 0,0074 & 0,0102 & 0,0409 & 0,0101 & 0,0061 \\
\hline 0,0000 & 0,0004 & 0,0000 & 0,0113 & 0,0001 & 0,0013 \\
\hline 0,0073 & 0,0155 & 0,0078 & 0,0002 & 0,0052 & 0,0250 \\
\hline 0,0009 & 0,0057 & 0,0005 & 0,0510 & 0,0043 & 0,0001 \\
\hline
\end{tabular}

Tabela 49 - Respectivas incertezas associadas aos polinômios de ajuste

\begin{tabular}{|c|c|c|c|c|c|}
\hline \multicolumn{2}{|c|}{ Polinômio de ajuste de grau 1} & \multicolumn{2}{|c|}{ Polinômio de ajuste de grau 2} & \multicolumn{2}{|c|}{ Polinômio de ajuste de grau 3} \\
\hline uTS $_{\text {1ajust }}$ & uTS $_{\text {2ajust }}$ & uTS $_{1 \text { ajust }}$ & uTS $_{\text {2ajust }}$ & uTS $_{1 \text { ajust }}$ & uTS $_{\text {2ajust }}$ \\
\hline${ }^{\circ} \mathrm{C}$ & ${ }^{\circ} \mathrm{C}$ & ${ }^{\circ} \mathrm{C}$ & ${ }^{\circ} \mathrm{C}$ & ${ }^{\circ} \mathrm{C}$ & ${ }^{\circ} \mathrm{C}$ \\
\hline 0,0554 & 0,0921 & 0,0576 & 0,1385 & 0,0607 & 0,1015 \\
\hline
\end{tabular}

Tabela 50 - Erros sistemáticos associados aos valores corrigidos de TS $_{1}$ e TS 2

\begin{tabular}{|c|c|c|c|c|}
\hline \multicolumn{5}{|c|}{ Erro sistemático ajustado dos sensores $\mathrm{TS}_{1}$ e $\mathrm{TS}_{2}$} \\
\hline \multicolumn{2}{|c|}{$\begin{array}{c}\text { Temperatura indicada pelas } \\
\text { termorresistências corrigidas } \\
\text { pelo polinômio de ajuste de } \\
\text { menor incerteza }\end{array}$} & \multirow{2}{*}{$\begin{array}{c}\text { Média das leituras corrigidas } \\
\text { indicada pelo do banho térmico } \\
\text { TP }_{\text {médio }} \\
\end{array}$} & \multicolumn{2}{|c|}{$\begin{array}{c}\text { Diferença entre a temperatura corrigida indicada } \\
\text { pelas termorresistências e a média das leituras } \\
\text { corrigida indicada pelo banho térmico }\end{array}$} \\
\hline $\mathrm{TS}_{1 \text { ajust }}$ & TS 2ajust & & $\mathrm{E}\left(\mathrm{TS}_{1 \text { ajust }}-\mathrm{TP} \mathrm{P}_{\text {médio }}\right)$ & $\mathrm{E}\left(\mathrm{TS}_{\text {2ajust }}-\mathrm{TP} \mathrm{P}_{\text {médio }}\right)$ \\
\hline${ }^{\circ} \mathrm{C}$ & ${ }^{\circ} \mathrm{C}$ & ${ }^{\circ} \mathrm{C}$ & ${ }^{\circ} \mathrm{C}$ & ${ }^{\circ} \mathrm{C}$ \\
\hline 2,4 & 2,4 & 2,4 & 0,0 & 0,0 \\
\hline 3,4 & 3,4 & 3,4 & 0,0 & 0,0 \\
\hline 5,2 & 5,3 & 5,3 & $-0,1$ & 0,0 \\
\hline 5,5 & 5,5 & 5,5 & 0,0 & 0,0 \\
\hline 6,3 & 6,3 & 6,2 & 0,1 & 0,1 \\
\hline 7,6 & 7,5 & 7,7 & $-0,1$ & $-0,2$ \\
\hline 9,2 & 9,1 & 9,2 & 0,0 & $-0,1$ \\
\hline 11,3 & 11,4 & 11,3 & 0,0 & 0,1 \\
\hline 12,6 & 12,7 & 12,7 & $-0,1$ & 0,0 \\
\hline 14,8 & 14,7 & 14,8 & 0,0 & $-0,1$ \\
\hline 16,3 & 16,4 & 16,3 & 0,0 & $-0,1$ \\
\hline 18,3 & 18,3 & 18,2 & 0,1 & 0,1 \\
\hline 20,2 & 20,2 & 20,2 & 0,0 & 0,0 \\
\hline 22,6 & 22,5 & 22,7 & $-0,1$ & $-0,2$ \\
\hline 25,3 & 25,4 & 25,3 & 0,0 & 0,1 \\
\hline
\end{tabular}




\section{Anexo A: Certificado de calibração do medidor de vazão Endress Hauser}

Empresa: Faculdades Católicas

CLIENTE

Endereco: Rua Marqués de Sẫo Vicente, 225 - Gávea - Rio de Janeiro - RI

5olicitante: Faculidades Catdlicas / Contato: (21) 3527-1542

CARACTERISTICAS DO INSTRUMENTO

Medidar de Vaz
Identificaça:

Identificaço:
MEDIDOR

Fabricante: Endress+Hause:

Modelo: Promes 0

N/S: PAD21392000

Faixa calibrada: $(8$ a 40$) \mathrm{m}^{3} / \mathrm{a}$

Fator encontrada: Fact Vol: 1.0000; Fact Mass: 1.0000

\begin{tabular}{|c|c|c|c|c|c|}
\hline \multicolumn{6}{|c|}{ PADAOESS UTILIZADOS } \\
\hline Identificacso & Descriçato & Acredtaçáa & Cerlificado & Data da casibraçao & Volidade \\
\hline$M M-01$ & Medider de vazมิด & RAC-CAL 0527 & $6017 / 19$ & 07.2010 & 07.2021 \\
\hline$M M-02$ & Medudor de vazäo & RBC-CAL 0439 & E11614A19 & 06.2019 & 06.2021 \\
\hline
\end{tabular}

METODOLOGIA APLICADA

Descriçāo: Medidor de vazăo de $2^{*}$

INOICADOR

Fabricante: Endress+Hauser

Madelo: Promag D

N/S: PA021392000

Valor de ums divisalo: $0,001 \mathrm{~m}^{3} / \mathrm{h}$

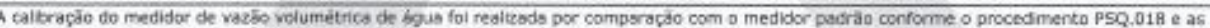

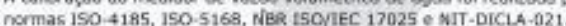

Os resukados da calibracho referem-se aco valores medias de 3 mediches para cado ponto callorado.

\begin{tabular}{|c|c|c|c|c|c|c|c|c|}
\hline \multicolumn{9}{|c|}{ RESULTADOS } \\
\hline \multicolumn{9}{|c|}{ ANTES DO AJUSTE } \\
\hline & $\begin{array}{l}\text { Vazsa de } \\
\text { caibraçá }\end{array}$ & $\begin{array}{l}\text { Valor médo } \\
\text { vudicaso pelo } \\
\text { medidor }\end{array}$ & $\begin{array}{l}\text { Valor medin } \\
\text { be referéncia }\end{array}$ & Tendencis & Desvio padraso & $\begin{array}{l}\text { Incerteza } \\
\text { expandista }\end{array}$ & $\begin{array}{l}\text { Fator de } \\
\text { abrangenva }\end{array}$ & $\begin{array}{l}\text { Grau de } \\
\text { Iberdade } \\
\text { efetivo } \\
\text { fvetf }\end{array}$ \\
\hline & 8 & 8.17120 & $8,018<2$ & 1,91 & 0.01. & 0.20 & $\frac{1.00}{2.00}$ & nankio \\
\hline & 16 & 16.37399 & 16,06048 & 1,95 & 0,01 & 0.22 & 2,00 & Vantios \\
\hline & 24 & 24.42280 & 24,05754 & 1,52 & 0.03 & 0,23 & 2,00 & mantioo \\
\hline & 32 & 32,34898 & 32,00671 & 1,07 & 0,04 & 0.22 & 2,03 & 87 \\
\hline * & 40 & 3966631 & 39.27044 & 0.73 & 0.07 & 0.26 & 2,14 & 19 \\
\hline \multicolumn{9}{|c|}{ APÓS O ANUSTE } \\
\hline & 8 & 806368 & 8.01348 & 0.63 & 0.01 & 0.20 & 2.00 & nanióo \\
\hline & 16 & 16,11956 & 16,02091 & 0,62 & 0.02 & 0.22 & 2,00 & Wanto \\
\hline & 24 & 2408790 & 23.97792 & 0.46 & 0,01 & 0.22 & 2.00 & intanno \\
\hline & 32 & 31.97469 & 31,99432 & -0.06 & 0.02 & 0.21 & 2,00 & inntio \\
\hline & 40 & 3956251 & 39.75970 & $-0,50$ & 0,02 & 021 & 2,00 & \\
\hline
\end{tabular}

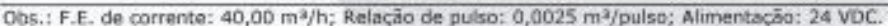

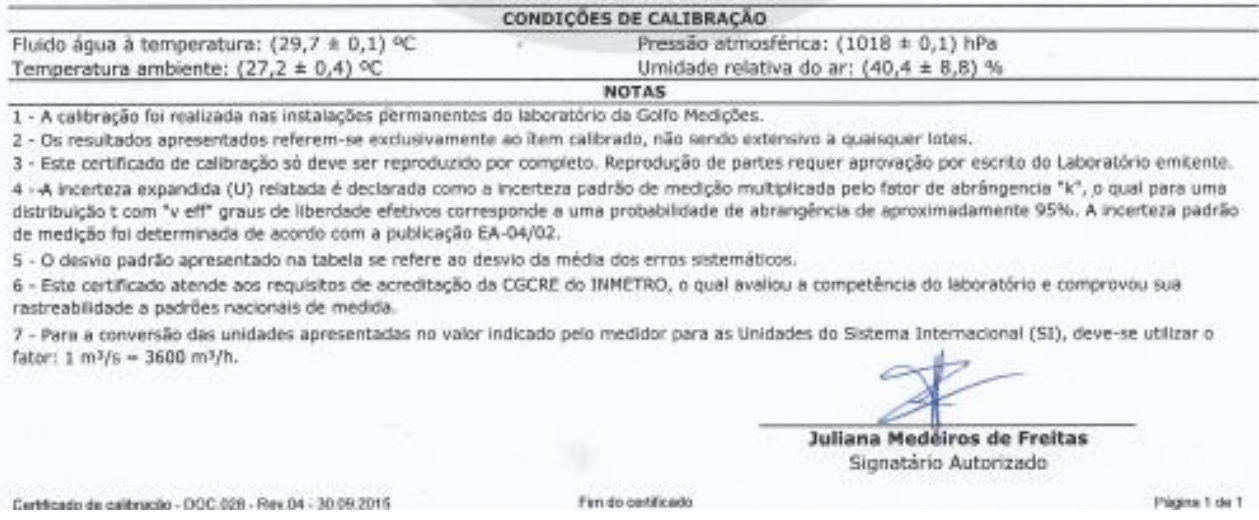




\section{Anexo B: Certificado de calibração do Manômetro Digital SALVI CASAGRANDE}

\section{Kiltler}

CERTIFICADO DE CALIBRAÇÄO $n^{\circ}$ : T $53.480 / 18 \quad$ Pagina: 1 de 1

SOLICITANTE : FACULDADES CATOLICAS

CONTRATANTE : SALVI CASAGRANDE MED. E AUT. LTDA

Ordem de Servico : N/C

Temperatura $\left({ }^{\circ} \mathrm{C}\right): 25$

Data de Calibraçäo : 23/11/2018 Validade : 12 Meses. Umidade $(\%):+1-60$

CARACTERISTICAS DO MATERIAL

Material : Manometro Digital

Cap. De Mediçãa : 0 a $15 \mathrm{~kg} f / \mathrm{cm}^{2}$

$\emptyset 100 \mathrm{~mm}$

Fabricante: Salvi

$\mathrm{N}^{2}$ do Série : 0006300-01 Caixa : Inox

Modelo : Salvpress $100 \mathrm{~B}$

Identificação: N/C

Resoluçăo : 0,01

PADRŌES UTILIZADOS

Manometro Digital marca Salcas , $n^{\circ}$ ID: Tec-04, $n^{0}$ serie $85618, n^{*}$ cert.CAL- $147148 / 17$ - Valdo alb $05 / 2019$

PROCEDIMENTO DE CALIBRAÇÄO CONFORME NORMA ABNT NBR 14105-1

RASTREABILIDADE DOS INSTRUMENTOS Os instrumentos utilizados nesta calibração

encontram-se rastreados ou calibrados por equipamentos rastreados junto a padrōes primários da REDE BRASILEIRA DE CALIBRAÇĀO (RBC) - INMETRO.

RESULTADO DA CALIBRAÇĀo

\begin{tabular}{|c|c|c|c|c|c|c|c|c|c|c|c|}
\hline Vve Kgf & Vo1 A & Vo1 D & Vo2 A & $\mathrm{V}_{0} 2 \mathrm{D}$ & Vm & Ip & Ep & Im & $\mathrm{Ee}$ & It & K IVeff \\
\hline 0 & 0,00 & 0,00 & 0,00 & 0,00 & 0,00 & 0,000 & 0,00 & 0,00 & 0,00 & 0,00 & $2,00 \mid \approx$ \\
\hline 3 & 3,01 & 3,01 & 3,01 & 3,01 & 3,01 & 0,010 & 0.00 & 0,01 & 0,01 & 0,02 & $2,00 \mid \infty$ \\
\hline 6 & 6,04 & 6,04 & 6,04 & 6,02 & 6,04 & 0,010 & 0,00 & 0,01 & 0,04 & 0.05 & $2,00 \mid-$ \\
\hline 9 & 9,05 & 9,06 & 9,05 & 9,05 & 9.05 & 0,010 & 0,00 & 0,01 & 0,05 & 0,06 & $2,00 /=$ \\
\hline 12 & 12,08 & 12,08 & 12.06 & 12.06 & 12.07 & 0,010 & 0,03 & 0,04 & 0,07 & 0,11 & $2,00 \mid \approx$ \\
\hline 15 & 15,15 & 15,14 & 15,15 & 15.16 & 15,15 & 0,010 & 0,00 & 0,01 & 0,15 & 0,16 & $2,00 \mid \approx$ \\
\hline
\end{tabular}

Terminologia Uenlizada :

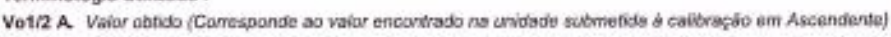

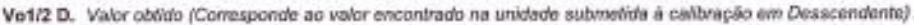

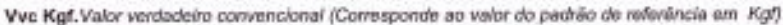

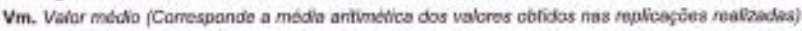

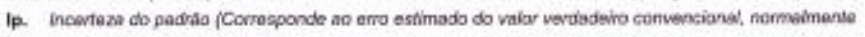
correspendendo a incerteza tats/ do valar fornecido pelo pourdio)

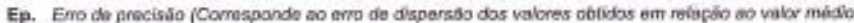
cakculade para um limes de confisaga de $95 \%$, fambem contecibo cano $K-2$ )

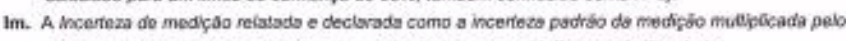

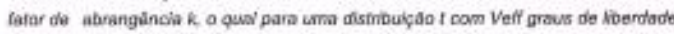

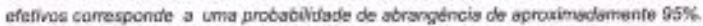

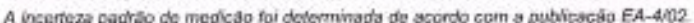

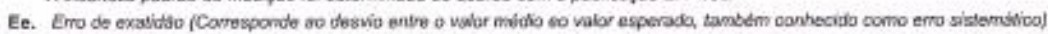

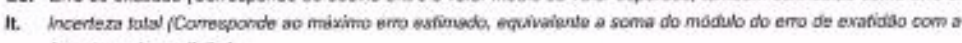
incerteza de madirablo).

OBS: Este certificado só se aplica ao material calibrado, năo se estendendo a quaisquer lotes mesmo que similares e nకెo deve ser reproduzido, total ou parcialmente, sem prévia autorizaçâo.

Calibrado por

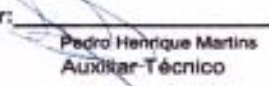

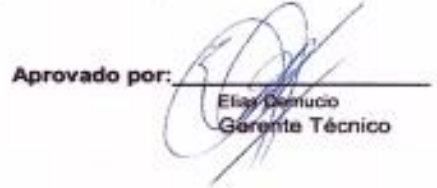




\title{
Anexo C: Certificado de calibração do banho térmico HAAKE
}

Página 1 de 2

\author{
Pontiricia Univemsionde Chtóbica \\ DO RIO DE JANEIHO

\section{CERTIFICADO DE CALIBRAÇÃO LABORATORIO DE TEMPERATURA}

Certificado N PósMQ1-001-18

Data de Calibração: 20/06/2018

Data de Emissão: 20/06/2018

1. IDENTIFICAÇÃO DO CLIENTE
Razao Soclal
Endereço
Programa de P05-Graduaçăo em Metrologla (PUC-Rlo)
Instrumento
Indlcador digltal de um banho termico

2. IDENTIFICAÇÃO DO INSTRUMENTO

\begin{tabular}{|c|c|}
\hline Nome do Instrumento & Indlcador digltal de um banho termico \\
\hline $\begin{array}{l}\text { Fabricante/Modelo } \\
\text { Nümero de Serle }\end{array}$ & $\begin{array}{l}\text { Haake/TYP 002-9979 } \\
198000400 / 016\end{array}$ \\
\hline Falxa de Medlç̧a & 0,0 a $100,0^{\circ} \mathrm{C}$ \\
\hline Resol & $0,1^{\circ} \mathrm{C}$ \\
\hline
\end{tabular}

3. IDENTIFIÇÅO DO PADRÃO UTILIZADO
Nome do Instrumento : : Termometro de LIquido em Vidro de Mercurio (TLV)
Fabricante / Falxa De Medlçåa : Incotherm (12616) /-10,9 a +52,7 ${ }^{\circ} \mathrm{C}$
Nümero do Certiflcado : : 0062
Laboratorlo de Callbraçào $\quad \vdots$ LPTIITUC - PUC-RIo

4. PROCEDIMENTO DE CALIBRAÇÅO

O Instrumento fol callbrado por comparaçăo direta ao padrăo do laboratorib, em conformldade ao procedimento CEM: TH-005 (Callbraçăo por comparaçăo de reslstenclas termometricas de platina).

\section{RESULTADOS DA CALIBRAÇÅO}

\begin{tabular}{|c|c|c|c|c|}
\hline $\begin{array}{l}\text { Temperatura Indloada } \\
\text { pelo Inctrumento }\end{array}$ & $\begin{array}{c}\text { Tomperatura AJuctada } \\
\text { pelo pollnomlo }\end{array}$ & $\begin{array}{c}\text { Temperatura Indloada } \\
\text { pelo Padrtso }\end{array}$ & Tenddnola & $\begin{array}{l}\text { Inoorteza } \\
\text { Expandlda }\end{array}$ \\
\hline$T_{\text {ind }}$ & $\mathrm{T}_{\mathrm{a}}$ & $\mathrm{T}_{\mathrm{f}}$ & $\mathrm{t}$ & $U_{\mathrm{s}}$ \\
\hline${ }^{\circ} \mathrm{C}$ & ${ }^{\circ} \mathrm{C}$ & ${ }^{a} \mathrm{c}$ & ${ }^{\circ} \mathrm{C}$ & ${ }^{\circ} \mathrm{C}$ \\
\hline 12,3 & 12,3 & 12,25 & 0,05 & 0,19 \\
\hline 15,3 & 15,4 & 15,43 & $-0,03$ & 0,20 \\
\hline 18,3 & 18,4 & 18,40 & 0,00 & 0,16 \\
\hline 20,2 & 20,3 & 20,37 & $-0,07$ & 0,17 \\
\hline 24,2 & 24,3 & 24,37 & $-0,07$ & 0,17 \\
\hline 28,6 & 28,8 & 28,80 & 0,00 & 0,16 \\
\hline 30,1 & 30,3 & 30,32 & $-0,02$ & 0,17 \\
\hline 35,0 & 35,2 & 35,30 & $-0,10$ & 0,16 \\
\hline 40,1 & 40,3 & 40,30 & 0,00 & 0,16 \\
\hline 45,0 & 45,3 & 45,35 & $-0,05$ & 0,16 \\
\hline 50,0 & 50,3 & 50,32 & $-0,02$ & 0,17 \\
\hline 52,0 & 52,2 & 52,33 & $-0,13$ & 0,17 \\
\hline
\end{tabular}

Legenda da Tabela:

- Tha: Medla de duas lelturas do instrumento.

- Ta: Temperatura ajustada pelo pollinomlo de ajuste, obtldo pelo Metodo dos Minímos Quadrados Oroinarios.

- $T_{a}=a \cdot\left(T_{\text {ind }}\right)^{2}+b \cdot\left(T_{\text {ind }}\right)+c ;(a=-0,0002 ; b=+1,0177 ; c=-0,1371)$

- ti tendencla $\left(t=T_{a}-T_{p}\right)$

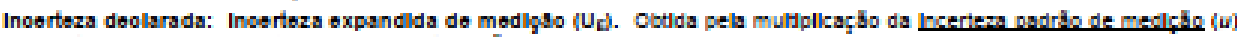

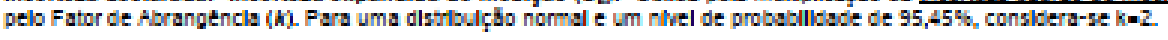

A incerteza expandida de meolçăb $\left(U_{k}\right)$ e o fator de abrangencla $(k)$ foram cakulados segundo o procedimento estabelecldo no documento JCGM 100:2008 - Gubie to the expression of uncertahnty in measurement, publlcado pelo BIPM. 
Página 2 de 2

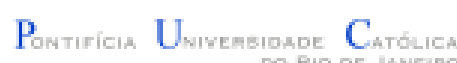

DO RIO OE JANTIERO

\section{EQUAÇÃO PARA CÁLCULO DO VALOR DA TEMPERATURA AJUSTADA}

A Equação (polnomlal) de Ajuste, a segulr, representa a natureza flsıca da callbraçăo, permitindo ao usuario do Banho Termico calcular a temperatura ajustada $\left(T_{\mathrm{a}},{ }^{\circ} \mathrm{C}\right)$, a partir da leltura Indlcada pelo instrumento $\left(\mathrm{T}_{\mathrm{ins}},{ }^{\circ} \mathrm{C}\right)$ :

$T_{a}\left({ }^{\circ} \mathrm{C}\right)=(-0,0002) \cdot\left(T_{\text {ind }}\right)^{2}+(1,0177) \cdot\left(T_{\text {ind }}\right)-0,1371$

\section{REPRESENTAÇÃO GRÁFICA DA CURVA DE CALIBRAÇÃO DO BANHO TÉRMICO}

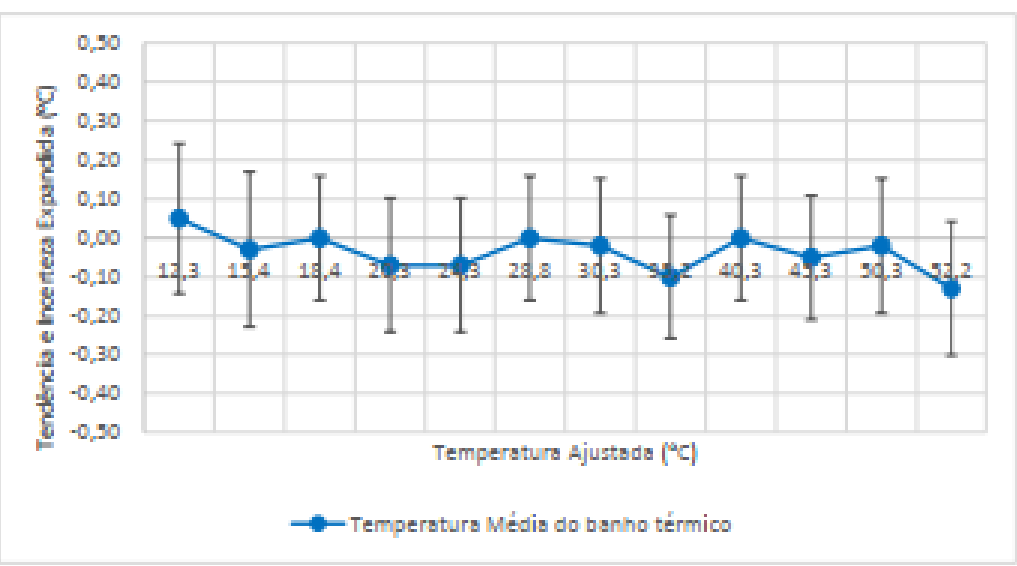

\section{OBSERVAÇO̊ES}

Condiçöes Ambientais:

- Temperatura ambiente durante o processo de cambraça: $23,4^{\circ} \mathrm{C} \equiv 0,1^{\circ} \mathrm{C}$

- Humidade relattva do ar durante o processo de cambraçao: (HR): $55 \% \pm 1 \%$

Homogeneidade do banho térmico: A homogeneidade do banho foi avaliada para três níveis de temperatura $\left(28,2{ }^{\circ} \mathrm{C} ; 35,0^{\circ} \mathrm{C}\right.$ e $52,1^{\circ} \mathrm{C}$ ). Para todos $05 \mathrm{Cas} 06$, o malor gradlente observado numa zona do banho dellmitiada por uma crrcunferencla de $55 \mathrm{~mm}$ de dlametro fol de $0,05{ }^{\circ} \mathrm{C}$, medida pelo padrå̃.

Escopo do Certificado:

- Apilicavel apenas para as condiçoes especmcadas e falka da canoraçáo realizada.

- Este Certincado esta em conformilade as recomendaçes da ABNT NBR ISOMEC 17025:2017 Requlsitos Gerals para Competêncla de Laboratorlos de Ensalo e Cakioraçálo.

Reprodução parcial ou total deste Certificado: Sob autontzaçáo do laboratorio responsavei.

Eng. Jefferson Luiz Rangel Rios Metrologista
Maurício N. Frota, PhD

Responsável pela Calibraçăo

Fim do Certificado 